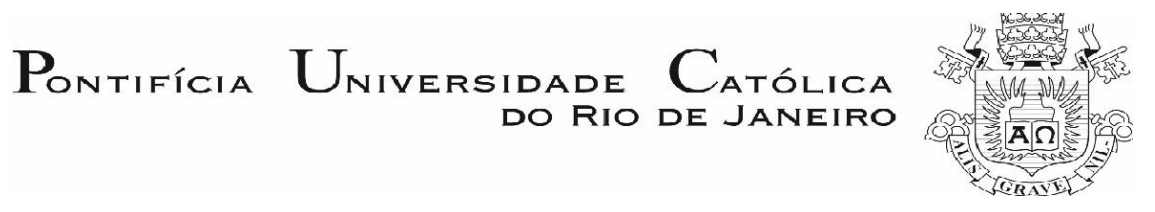

Carolina Gonçalves de Almeida

\begin{abstract}
A relação de estudantes de Pedagogia com a escrita
\end{abstract}

Dissertação de Mestrado

Dissertação apresentada como requisito parcial para obtenção do grau de Mestre pelo Programa de Pós-graduação em Educação do Departamento de Educação do Centro de Teologia e Ciências Humanas da PUC-Rio.

Orientadora: Prof. ${ }^{a}$ Zena Winona Eisenberg Coorientadora: Prof. ${ }^{a}$ Erica dos Santos Rodrigues

Rio de Janeiro Março de 2016 


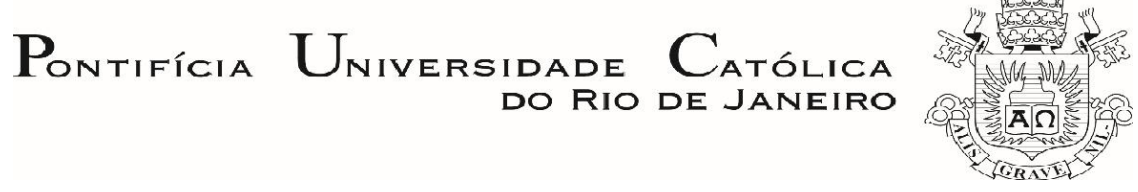

Carolina Gonçalves de Almeida

\section{A relação de estudantes de Pedagogia com a escrita}

Dissertação apresentada como requisito parcial para obtenção do grau de Mestre pelo Programa de Pós-graduação em Educação do Departamento de Educação do Centro de Teologia e Ciências Humanas da PUC-Rio. Aprovada pela Comissão Examinadora abaixo assinada.

Prof. ${ }^{a}$ Zena Winona Eisenberg Orientadora Departamento de Educação - PUC-Rio

Prof. ${ }^{\text {a Erica dos Santos Rodrigues }}$ Coorientadora Departamento de Letras - PUC-Rio

Prof. ${ }^{a}$ Rosaly Hermengarda Lima Brandão Departamento de Educação - PUC-Rio

Prof. Marcelo Macedo Corrêa e Castro Faculdade de Educação - UFRJ

Prof. ${ }^{a}$ DENISE BERRUEZO PORTINARI Coordenadora Setorial do Centro de Teologia e Ciências Humanas PUC-Rio

Rio de Janeiro, 07 de Março de 2016 
Todos os direitos reservados. É proibida a reprodução total ou parcial do trabalho sem autorização do autor, da orientadora, da coorientadora e da universidade.

\section{Carolina Gonçalves de Almeida}

Graduada em Pedagogia na Universidade Federal do Rio de Janeiro no ano de 2013. Professora de Educação Infantil da Prefeitura do Rio de Janeiro desde 2014. Membro do Grupo de Pesquisa Desenvolvimento Humano e Educação - Grudhe, da PUC-Rio.

Ficha Catalográfica

Almeida, Carolina Gonçalves de

A relação de estudantes de pedagogia com a escrita / Carolina Gonçalves de Almeida ; orientadora: Zena Eisenberg ; coorientadora: Erica dos Santos Rodrigues. - 2016.

$173 \mathrm{f.} ; 30 \mathrm{~cm}$

Dissertação (mestrado) - Pontifícia Universidade Católica do Rio de Janeiro, Departamento de Educação, 2016.

Inclui bibliografia

1. Educação - Teses. 2. Estudantes de pedagogia. 3. Escrita. 4. Professores. I. Eisenberg, Zena. II. Rodrigues, Erica dos Santos. III. Pontifícia Universidade Católica do Rio de Janeiro. Departamento de Educação. IV.Título. 


\section{Agradecimentos}

Desta vez, em primeiro lugar, eu agradeço a mim mesma e a todo o meu esforço realizado para conseguir ingressar na PUC e ter a capacidade de realizar este belo trabalho.

Agradeço imensamente à amiga de faculdade - da UFRJ - Thaísa Souza da Silva, uma pessoa maravilhosa, que me ajudou a realizar duas grandes conquistas no ano de 2013, que foram: conseguir realizar a prova de mestrado para ingressar na PUC e conseguir realizar a prova prática para professora de Educação Infantil do Município do Rio de Janeiro - ambas no mesmo dia. Graças a ela, eu consegui alcançar com êxito esses dois feitos.

À PUC-Rio e à CAPES pelos auxílios concedidos, fundamentais para execução deste trabalho.

À orientadora Zena Eisenberg por ter me acolhido e me guiado em todo o trabalhoso percurso.

À coorientadora Erica dos Santos Rodrigues por ter aceitado trabalhar conjuntamente com nossas perspectivas.

Aos professores que aceitaram fazer parte desta banca, Rosaly Hermengarda Lima Brandão e Marcelo Macedo Corrêa e Castro.

Finalmente, agradeço a todos os que participaram deste trabalho, direta ou indiretamente.

Muito obrigada a todos. 


\title{
Resumo
}

\begin{abstract}
Almeida, Carolina Gonçalves de; Eisenberg, Zena Winona. A relação de estudantes de Pedagogia com a escrita. Rio de Janeiro, 2016. 173 p. Dissertação de Mestrado - Departamento de Educação, Pontifícia Universidade Católica do Rio de Janeiro.
\end{abstract}

Este trabalho teve como objetivo compreender a relação dos estudantes de Pedagogia com a escrita a partir de suas autoavaliações e também com base nas percepções dos professores. Foram selecionadas duas disciplinas específicas do curso de Pedagogia de uma universidade: uma obrigatória e outra optativa. Assim, a pesquisa consiste em um estudo de caso, com as técnicas de questionário e entrevista. Os dados foram analisados com o auxílio dos programas Excel e Atlas Ti. Os resultados obtidos indicam que as disciplinas específicas estudadas não apenas auxiliam os estudantes que necessitam de apoio, como também ampliam sua base de conhecimento.

\section{Palavras-chave}

Estudantes de Pedagogia; escrita; formação de professores. 


\section{Abstract}

Almeida, Carolina Gonçalves de; Eisenberg, Zena Winona (Advisor). The relationship between Pedagogy students and writing. Rio de Janeiro, 2016. 173 p. Thesis - Departamento de Educação, Pontifícia Universidade Católica do Rio de Janeiro.

This work aimed to comprehend the relationship Pedagogy students have with writing based on their self-assessment and on teachers' perceptions. Two courses were selected from the curriculum of a Teacher's Education course, that focus on writing skills. This is a case study, and our methodology encompassed the use of questionnaires and interviews. Data were transcribed and entered in Excel and in Atlas $T i$ for analyses. The results suggest that Pedagogy students benefit from the courses offered, both in improving their weak areas and in expanding their knowledge base.

\section{Keywords}

Pedagogy students; writing; teacher training. 


\section{Sumário}

1. Introdução

2. A escrita e os estudantes de graduação

2.1. O papel do professor em sala de aula: o domínio da norma padrão e de habilidades de escrita

2.2. Processamento cognitivo da escrita 34

2.3. Qualidades de um bom texto e habilidades de escrita 40

3. A pesquisa 50

3.1. Objetivos e questões de pesquisa 51

3.2. Técnicas de pesquisa 53

3.3. Piloto 55

3.4. Recrutamento $\quad 55$

3.5. Perfil dos participantes $\quad 57$

4. Análise de dados e problematizações 63

4.1. Considerações iniciais entre as estudantes 63

4.1.1. Visão dos professores a respeito das estudantes 66

4.2. Concepções de escrita dos docentes 68

4.2.1 Relação entre leitura e escrita 73

4.3. Relação das disciplinas da Pedagogia com a escrita 75

4.3.1. Dificuldades apresentadas: avaliação dos discentes e dos docentes $\quad 76$

4.3.2. Correções: o quê e como? 86

4.3.3. Contextualização do modelo processual da escritura 89

4.4. Avaliação das disciplinas - entrevistas 95

4.4.1. Avaliação da disciplina optativa 95 
4.4.2. Avaliação da disciplina obrigatória 102

4.4.3. Avaliação das disciplinas específicas pelos docentes 104

4.5. Nivelamento de Português 107

4.6. Análise da grade curricular 111

4.6.1. Perspectiva dos discentes 112

4.6.2. Perspectivas dos docentes 115

4.6.3. Outras sugestões 118

4.7. Relação com a Educação Básica 121

5. Considerações finais 127

$\begin{array}{ll}\text { Apêndices } & 135\end{array}$

Apêndice I - Termo de consentimento Livre e Esclarecido - professor 136

Apêndice II -Termo de consentimento Livre e Esclarecido - aluno 138

Apêndice III - Questionário dos estudantes 140

Apêndice IV - Roteiro de entrevista com os alunos 146

Apêndice $V$ - Roteiro de entrevista com os professores das disciplinas específicas

Apêndice $\mathrm{VI}$ - Roteiro de entrevista com os professores do curso de Pedagogia 


\section{Lista de quadros}

Quadro 1. Participantes da pesquisa

Quadro 2. Formação dos professores do Curso de Pedagogia da instituição estudada

Quadro 3. Distribuição das alunas por grupos de disciplinas

Quadro 4. Distribuição das respostas da escolarização básica por aluno e por etapa

Quadro 5. Domínio da norma padrão por alunas da categoria "formação mista"

Quadro 6. Contribuição além da escola para alunas da categoria "formação mista"

Quadro 7. A importância da escrita para os professores

Quadro 8. Definição das dificuldades dos alunos pelos docentes

Quadro 9. Frequência e gravidade das dificuldades dos alunos, de acordo com os professores

Quadro 10. Avaliação das alunas das manifestações dos professores sobre seu desenvolvimento na escrita

Quadro 11. Percepção dos professores de progressos dos alunos

Quadro 12. Aspectos que os professores corrigem nas produções textuais

Quadro 13. Como os professores realizam correções

Quadro 14. Como os professores das disciplinas específicas realizam correções

Quadro 15. Propostas das disciplinas optativas relacionadas à ampliação das bases de conhecimento da memória de longo prazo dos estudantes

Quadro 16. Motivo da inscrição na disciplina optativa

Quadro 17. Avaliação dos docentes das disciplinas específicas pelos alunos 
Quadro 18. Avaliação da disciplina optativa pelas alunas 99

Quadro 19. Avaliação das alunas da necessidade da disciplina optativa 101

Quadro 20. Percepção de progressos nas alunas das turmas das disciplinas optativas

Quadro 21. Opinião dos docentes sobre a prova de nivelamento

Quadro 22. Distribuição das estudantes para avaliação da grade curricular

Quadro 23. Avaliação das discentes que julgam insuficiente a grade curricular do curso de Pedagogia

Quadro 24. Perfil das alunas que consideram o currículo do curso

Quadro 25. Avaliação dos professores quanto à grade curricular do curso 115 


\section{Lista de tabelas}

Tabela 1. Espaço de formação da escolarização básica das alunas $\quad 60$

Tabela 2. Domínio da norma padrão de estudantes de formação exclusivamente em escola pública

Tabela 3. Contribuição da escola para as estudantes de formação exclusivamente em escolas públicas

Tabela 4. Contribuição da escola para as estudantes de formação exclusivamente em escola privada

Tabela 5. Maiores dificuldades na produção escrita - autoavaliação das alunas

Tabela 6. Apreciação das práticas comuns entre os professores pelos discentes 
Se leio com prazer essa frase, essa história ou essa palavra, é porque foram escritas no prazer (esse prazer não está em contradição com as queixas do escritor). Mas e o contrário? Escrever no prazer me assegura - a mim, escritor - o prazer do meu leitor? De modo algum. Esse leitor é mister que eu o procure (que eu o "drague"), sem saber onde ele está. Um espaço de fruição fica então criado. Não é a "pessoa" do outro que me é necessária, é o espaço: a possibilidade de uma dialética do desejo, de uma imprevisão do desfrute: que os dados não estejam lançados, que haja um jogo. (ROLAND BARTHES, 2013, p. 9)

Às vezes tenho a impressão de que escrevo por simples curiosidade intensa. É que, ao escrever, eu me dou as mais inesperadas surpresas. É na hora de escrever que muitas vezes fico consciente das coisas, das quais, sendo inconsciente, eu antes não sabia que sabia.

(CLARICE LISPECTOR, 2010, p. 85) 


\section{A relação de estudantes de Pedagogia com a escrita}

\section{Introdução}

Toda pesquisa que tem como objeto principal a formação de professores é muito importante para o desenvolvimento e aprimoramento da profissão docente. Estudar os alunos do curso que forma professores - no nosso caso, o curso de Pedagogia - que irão atuar nas mais diversas esferas da educação, principalmente nas séries iniciais do Ensino Fundamental com a alfabetização de crianças, constitui um ponto forte para a criação de políticas que visem aperfeiçoar a formação desse futuro professor. Nesse sentido, uma das ferramentas principais de seu trabalho é a escrita, que precisa ser condizente com e adequada ao meio de trabalho.

Como sugere Leta (2005), a escrita como objeto de investigação é um campo recente e ainda "pobre" quando se trata da formação de professores. Para Marinho (2010), Cunha e Santos (2006) e Leta (2005), a escrita universitária não tem recebido merecida atenção nas pesquisas e políticas educacionais de nosso país. Corrêa (2010) também observou que são poucos os trabalhos relacionados ao assunto e que é necessário explorar mais o campo, principalmente pelo fato de a Pedagogia ser um curso que forma professores.

Gnerre (2009) explicita a complexidade da área aqui estudada: a escrita. Diz ele:

O estudo da escrita e de suas implicações e conseqüências é uma área de pesquisa tão complexa que, ainda que concordemos sobre a centralidade de um núcleo de problemas, é difícil estabelecer ordens de prioridade ou relevância de objetos para outras áreas de pesquisa com relação a esse núcleo. Cada tipo de ordem de prioridade ou relevância de objetos e a inclusão ou a exclusão de algumas áreas de pesquisa representa uma visão do próprio campo de estudo da escrita. (GNERRE, 2009, p.39) 
De fato, a partir de um levantamento bibliográfico a respeito do assunto, foi possível perceber que a quantidade de literatura relacionada à escrita e à formação de professores é baixa, ainda muito restrita. Sendo assim, grande parte dos pressupostos teóricos aqui trabalhados será redimensionada de outras áreas e aqui adaptada.

A nossa pesquisa possui um alvo específico: a escrita de estudantes de Pedagogia. Como foi dito anteriormente, a área de pesquisa relacionada à escrita de futuros professores é um campo pouco explorado. Leta (2005) informou que sua tese estava vinculada a uma pesquisa institucional cujo foco era a leitura e a escrita, sendo que a primeira sobressaiu-se em relação à segunda devido ao fato de poucos alunos realizarem referências a ela - a escrita. Consideramos a escrita uma ferramenta fundamental para o trabalho docente. A partir do levantamento bibliográfico sobre o assunto, constatamos que é pouco estudado como a escrita é trabalhada nos cursos de Pedagogia. Sendo assim, privilegia-se neste trabalho a escrita para possibilitarmos uma melhor compreensão desta pequena área no gigantesco universo que compreende o campo da atuação docente em Educação. Vale esclarecer que em momento algum a relação da escrita com a leitura é negada, mas apenas prioriza-se o primeiro aspecto. Esclarecemos que direcionamos para esse campo o foco do trabalho, pois acreditamos que se tratássemos da relação entre leitura e escrita, a segunda poderia se ofuscar em relação à anterior.

O profissional habilitado que é o primeiro, teoricamente, a proporcionar o contato da criança com a escrita é o Pedagogo-Professor. É na Educação Infantil e nas séries iniciais do Ensino Fundamental que o docente irá atuar de modo a integrar a criança na educação escolar intencional formal (LIBÂNEO, 2013), em suas primeiras relações com a escrita ${ }^{1}$.

Desse modo, caracteriza-se como imprescindível a qualificação desse profissional para uma prática significativa e efetiva. Nas palavras de Libâneo (2013),

\footnotetext{
${ }^{1}$ Ratifica-se que são os primeiros contatos da criança com a escrita no espaço escolar intencional formal, ou seja, em momento algum é negada sua relação em outros espaços.
} 
o domínio de uma área de conhecimento é fundamental para o exercício da profissão, pois "não se pode exigir que os alunos adquiram um domínio sólido de conhecimentos se ele próprio [professor] não domina com segurança a disciplina que ensina” (LIBÂNEO, 2013, p. 78). Nesse sentido, faz-se necessário que o professor domine bem a área em que irá atuar para trabalhar de maneira eficaz e de qualidade. É importante que o professor domine as habilidades de escrita que serão utilizadas como instrumento e foco de seu trabalho.

O mesmo autor ainda menciona a dificuldade que o professor terá de enfrentar ao não dominar a área, impossibilitando um diálogo com os alunos em sala de aula e o inter-relacionamento do conteúdo com a realidade sócio-histórica do grupo. Bagno (2013) sugere que os professores têm de ensinar os alunos a escrever de acordo com as regras oficiais e que, por isso, os professores devem ser verdadeiros especialistas no assunto. $\mathrm{O}$ autor ainda critica fortemente as práticas docentes que inviabilizam a adequação da Língua Portuguesa ao nosso modelo de sociedade, sugerindo, assim, que o ensino permanecerá conservador e elitista.

Se observarmos atentamente esse cenário, será possível constatar uma situação bastante complexa. Se por um lado, o professor precisa estar adequadamente habilitado, dominando habilidades essenciais da escrita, assim como o conhecimento da norma padrão, por outro viés, é necessário que este docente esteja atento às necessidades de seus alunos de modo a adequar e integrar as melhores metodologias para o trabalho com a escrita de acordo com o perfil e bagagem de seus alunos.

Possenti (1996, 2011) e Geraldi (2011) apontam que a escola e, consequentemente, os professores têm o objetivo de ensinar o português em sua norma padrão, porém respeitando e observando as variedades linguísticas de seus alunos. É aqui que se encontra o $x$ da questão: enquanto o trabalho com os alunos deve ser realizado de maneira crítica, sempre se apresentando os "dois lados da moeda", por exemplo, ao explicarmos que muitos falam mulhé, mas que a escrita correta é mulher, o trabalho a ser realizado pelo professor deve estar baseado em todo um conhecimento técnico que ele tem que dominar justamente para saber explicar as 
convenções da escrita, que diferem da oralidade, dos dialetos. Nesse sentido, possuir habilidades na escrita é fundamental para sua atuação.

Nesse contexto, é necessário compreendermos dois conceitos importantes para o entendimento do estudo: o de norma padrão e o de escrita.

O que é a norma padrão? É uma dentre muitas variedades linguísticas, que, por diversos fatores, é tomada como o padrão a ser usado em documentos oficiais, nas escolas etc. As línguas variam e de acordo com Possenti (2011) "a variedade linguística é reflexo da variedade social e, como em todas as sociedades existe alguma diferença de status ou de papel, essas diferenças se refletem na linguagem" (POSSENTI, 2011, p.35). Intrinsecamente, não há uma variedade linguística que seja melhor em relação à outra. Trata-se de uma questão de adequação às situações de uso.

É comum ouvirmos o termo culta para qualificar a norma padrão, mas como apontam Possenti (1996) e Bagno (2013), tratar a norma como culta significa atrelá-la às camadas dominantes, apenas às pessoas ditas cultas e esse não é o objetivo do ensino da norma padrão. Então, ao realizarmos referências a essa norma, a desarticulamos da "boa linguagem" ou da "norma culta", respectivamente como os autores sugerem. Não se trata de uma questão de privilégios, mas sim da manutenção da norma a ponto de que esta não seja definitivamente esquecida. As variedades faladas são inúmeras, assim como as variedades escritas.

Mas será que escrever bem consiste apenas em dominar aspectos da norma padrão? Alves (2014) acredita que o domínio da escrita vai além do domínio dessa norma. A autora afirma que "o homem, mesmo dominando um artefato linguístico (ortografia, concordância, regência, vocabulário), não conseguirá apenas com o domínio do código linguístico escrever um bom texto" (ALVES, 2014, p. 13). Alves (2014) acrescenta que existem outros domínios que auxiliam na construção de bons textos e no desenvolvimento de habilidades de escrita, como o hábito de leitura.

Definir o que é a escrita é difícil. Koch e Elias (2015) afirmam que definir o que é escrever é uma tarefa complexa, visto que a atividade da escrita engloba uma multiplicidade de aspectos que podem variar, sejam eles de natureza linguística, cognitiva, cultural ou sócio-histórica. É comum observamos definições como: 
“escrever é expressar pensamento" ou "a escrita é uma forma de comunicação". Koch e Elias $(2015$, p. 32) explicam que essa variedade de concepções "nos faz pensar que o modo pelo qual concebemos a escrita não se encontra dissociado do modo pelo qual entendemos a linguagem, o texto e o sujeito que escreve". Mas, independentemente da concepção de escrita que um sujeito possui, é preciso considerar que "escrever melhor e de maneira objetiva e atraente é o grande desafio de quem lida profissionalmente com a palavra" (ALVES, 2014, p. 15).

Nesse contexto, um aspecto importante para o assunto é o conceito de legitimação, de Gnerre (2009). O autor destaca que o conceito está relacionado com a emergência política e econômica da variedade linguística utilizada por um determinado grupo social detentor de poder, "e tal variedade foi reproposta como algo de central na identidade nacional, enquanto portadora de uma tradição e de uma cultura" (GNERRE, 2009, p. 9). O próprio Bagno (2013) afirma que discutir língua é a mesma coisa que discutir política. Apesar de a linguagem ser caracterizada como forma de poder, independentemente de sua origem, é imprescindível que se tenha consciência de seu funcionamento macro: possibilidade de compreensão. Incorporando Bagno (2013), acreditamos que a linguagem estará vinculada negativamente ao poder apenas para aqueles que optarem por esse caminho, que a linguagem será utilizada como instrumento de discriminação apenas por aqueles que desejarem.

Aliás, cabe até mesmo ressaltar que, como sugerem Bagno (2013) e Libâneo (2013), a disciplina de Língua Portuguesa trabalha com habilidades, técnicas. Desse modo, sua aprendizagem é o ponto de partida para o aprendizado das outras áreas, sendo considerada sua aprendizagem inicial fundamental para um diálogo entre as diversas áreas do conhecimento. A questão central é o como a língua será trabalhada pelos professores na escola. Para Bechara (2006), a norma padrão deve ser sim ensinada nas escolas, mas como modalidade adquirida, complementar à coloquial e/ou familiar.

A partir das considerações anteriores de que a norma padrão precisa ser ensinada nas escolas e que seus professores devem estar habilitados para isso, 
direcionamos o foco da discussão para a formação de professores. Concordamos com Marin e Giovanni (2007, p. 38) quando mencionam que "não se pode aceitar, no âmbito das questões de base da educação escolar, o despreparo dos professores para o ensino e a aprendizagem da leitura e da escrita". Como será apresentado na seção 2.3. deste trabalho, existe um conjunto de elementos e conhecimentos de vários tipos que também são imprescindíveis para o domínio e para o trabalho com o ensino de leitura e escrita, que vão além da esfera da norma padrão. Não se trata de repudiar um estudante de graduação por ele apresentar dificuldades na escrita. É preciso atentar para o fato de que esse aluno se tornará um professor e que, por isso, é necessário propor medidas para solucionar a situação.

Diante do exposto, o objetivo geral do estudo foi compreender como ocorre a relação dos estudantes de Pedagogia com a escrita profissional e acadêmica através de duas vertentes: uma avaliação inicial e uma avaliação final dos estudantes que cursaram duas disciplinas específicas e uma avaliação dos docentes do curso e das disciplinas específicas estudadas.

É necessário deixar claro que consiste em um estudo de percepções, ou seja, a pesquisa investigou como alunos e professores compreendem uma determinada situação, não definindo a prática em si.

Os sujeitos da pesquisa são os estudantes de Pedagogia e os professores do Curso da Pontifícia Universidade Católica do Rio de Janeiro. O estudo foi realizado durante um semestre letivo em duas disciplinas de leitura e escrita do curso de Pedagogia: uma obrigatória e outra optativa.

Para investigar as questões da pesquisa, utilizei como base teórica, entre outros, os seguintes autores: Soares (2001), Leta (2005), Bechara (2006), Zuin e Reyes (2010), Geraldi (2011), Possenti (1996; 2011), Garcez (2012), Bagno (2013), Libâneo (2013), Koch e Travaglia (2013) e Koch (2014). São estudiosos da área que tratam sobre a relação da língua, da escrita com a formação de professores e algumas implicações para o campo educacional, como veremos adiante.

O trabalho está estruturado da seguinte forma: no capítulo 1 foi apresentado o tema de pesquisa, sua justificativa, o objeto, o campo de estudo e os referenciais 
teóricos que serão utilizados. Serão discutidos no capítulo 2, de modo teórico, quatro tópicos essenciais para a fundamentação deste estudo: (I) a importância da escrita para estudantes de Pedagogia e a relação que estabelecem com ela; (II) a importância do domínio da língua escrita de acordo com a norma padrão para o desempenho do papel de um professor; (III) o modelo processual da escritura e; (IV) uma visão sobre em que consiste uma boa escrita. O capítulo 3 exporá a metodologia que foi utilizada neste estudo, destacando as técnicas de pesquisa, o teste-piloto e as formas de recrutamento utilizadas. O capítulo 4 apresentará a análise dos dados obtidos junto com as problematizações, seguido do capítulo $5 \mathrm{com}$ as conclusões da pesquisa e sugestões de possíveis caminhos para trabalhos universitários. 


\section{A escrita e os estudantes de graduação}

Nesta seção, buscamos apontar alguns estudos que retratam a relação entre estudantes universitários e suas produções escritas. Intencionamos verificar possíveis contribuições das pesquisas acadêmicas para melhor compreensão do assunto.

Marin e Giovanni (2007) acreditam que o desempenho proficiente em leitura e escrita são condições fundamentais para a formação do professor e pesquisaram sobre as condições que estudantes de um Curso Normal Superior de uma instituição privada apresentam para atuar como docentes das séries iniciais, relatando a

[...] precariedade das condições de domínio dos conteúdos escolares básicos relacionados à leitura e à escrita indispensáveis para o exercício futuro da profissão docente nos primeiros anos do ensino fundamental, o que equivale a constatar, nessa parcela do alunado do ensino superior, indícios de falência do sistema escolar de ensino. (MARIN \& GIOVANNI, 2007, p. 15)

As autoras constatam três tipos de dificuldades existentes nesses estudantes: de expressão escrita, de compreensão de texto e de utilização de argumentos - todos relacionados a procedimentos implicados na leitura e na escrita e que vão ser trabalhados na escola pelo professor, como atividades informativas, descritivas, entre outras. Acrescentam ainda que os graduandos apresentam dificuldades com a língua escrita e que eles também são, muitas vezes, incapazes de detectar erros nas produções das crianças considerando marcas da oralidade presentes no texto. Afirmam elas:

Esses futuros professores não conseguem avaliar, julgar o desempenho do aluno a que se refere a questão em pauta, porque não conseguem identificar e analisar as dificuldades expressas na produção escrita desse aluno sob julgamento. Deixam de corrigir, e o que é pior, às vezes corrigem errado porque eles próprios apresentam as mesmas dificuldades que deveriam identificar, assinalar e corrigir. (MARIN \& GIOVANNI, 2007, p. 36) 
Mancini (2012) parte do princípio de que, após o curso de Pedagogia, espera-se que os estudantes produzam um texto de boa qualidade, mas que, pelo contrário, ao final fica evidenciado que eles concluem o curso com inúmeras 'dificuldades' ${ }^{2}$ na escrita. Mancini (2012) constatou que existe um elevado número de estudantes que concluem o curso com "deficiências linguísticas", sendo, em contraste, pequeno o percentual de estudantes que se autoclassificam com dificuldades na produção escrita - dado este que guarda coerência com Almeida (2013).

Santos (2006) analisou práticas de leitura e escrita das professorandas ${ }^{3}$ de um curso de Pedagogia de uma instituição privada. Além da análise do Projeto Político Pedagógico do Curso, ela utilizou um questionário para 41 alunos, com o intuito de traçar seu perfil socioeconômico e compreender suas práticas de leitura e escrita. Santos (2006) percebeu 3 concepções sobre a escrita entre as estudantes: como registro de acontecimentos diários, como expressão de pensamento e como instrumento capaz de desenvolver a criticidade.

A autora destaca que, na graduação, a escrita é utilizada para melhorar a compreensão de textos lidos através da construção de resumos, da organização textual das ideias do autor. Porém, esse processo não garante o desenvolvimento da autonomia do aluno, segundo Santos (2006), pois apenas se reproduzem as ideias daquele texto e não se constrói um posicionamento próprio do aluno. As estudantes na pesquisa de Santos (2006) declaram que os professores, em sua maioria, propõem trabalhos de textos individuais, mas os mesmos pouco interferem nas produções, ocorrendo poucas possibilidades de reescrita. Além disso, a autora também enfatiza que a quantidade de alunos em sala surge como um empecilho ao trabalho do professor, que fica impossibilitado de conseguir acompanhar paulatinamente o desenvolvimento de um aluno.

\footnotetext{
${ }^{2}$ Mancini (2012) menciona como dificuldades: a acentuação, a pontuação, a reforma ortográfica (a escrita de acordo com as novas regras), a coesão, a coerência, o foco narrativo (posição e/ou perspectiva de quem escreve), e o uso do verbo haver.

${ }^{3} \mathrm{O}$ termo professorandas é utilizado por Santos (2006) no sentido de referir-se às estudantes do curso de formação de professores, majoritariamente do sexo feminino.
} 
Santos (2006) percebe que as disciplinas que são mencionadas pelas professorandas como as que mais exigem a produção escrita de textos não são necessariamente aquelas específicas de linguagem. Por isso, a autora acredita que a habilidade de escrita pode e deve ser desenvolvida e trabalhada nas diversas disciplinas e por diferentes professores.

Já Corrêa (2010) observou o letramento dos futuros professores e o modo como são preparados para atuar como agentes do letramento. Através de uma observação empírica de cunho etnográfico, a autora pesquisou duas turmas do curso de Pedagogia, além de realizar uma entrevista com um grupo específico. A autora escolheu para realizar sua pesquisa duas disciplinas do curso que estavam relacionadas à Língua Portuguesa e, consequentemente, suas respectivas turmas. Entretanto, a observação foi tão interessante que Corrêa (2010) resolveu acompanhar uma das turmas por mais um semestre.

Sua pesquisa revelou, dentre inúmeros tópicos, a necessidade de criação da disciplina "Escrita Acadêmica", enfatizando as atividades de leitura e a escrita como objeto de todas as outras disciplinas, principalmente porque não existe disciplina sem tais elementos. Acreditamos, assim como a autora, que o curso de Pedagogia necessita de um apoio constante para com os alunos em sua produção escrita. Corrêa (2010) também tem uma grande contribuição para o campo da pesquisa na área educacional: indica a falta de preocupação do curso de Pedagogia com os futuros professores no que tange à sua produção textual/acadêmica.

Camargo e Britto (2011) pesquisaram o motivo da existência da disciplina Língua Portuguesa em diferentes cursos universitários, principalmente em relação aos cursos que não estão necessariamente relacionados à área. Como metodologia, utilizaram o levantamento de currículos de diferentes instituições e conseguiram identificar três concepções predominantes para a existência de tais disciplinas: (1) reparadora - o curso que quer suprir "deficiências" e apresenta um caráter compensatório, (2) instrumental - o curso que se preocupa com a aplicabilidade da língua e não com reflexões sobre ela e (3) discursivo-textual - o curso que percebe a leitura e a escrita como instrumentos para auxiliar na aquisição de conhecimentos. 
Das 53 instituições pesquisadas, os autores conseguiram constatar que 49 delas possuem, em seus cursos, uma ou mais disciplinas que se preocupam com o ensino de leitura e escrita. Os autores ressaltam que, independentemente da perspectiva adotada, todos os cursos partem da premissa de que "o domínio da escrita é condição da aprendizagem de outros conhecimentos" (CAMARGO \& BRITTO, 2011, p. 345).

Tavares e Cabral (2005) identificaram as estratégias mais utilizadas por estudantes universitários em relação às atividades de leitura, escrita e compreensão de textos, para perceber a importância que atribuem a tais competências para o sucesso acadêmico, além de destacar os níveis de competência em que os estudantes apresentam melhor desempenho. Os autores elaboraram e utilizaram um questionário para compreender tais aspectos e pesquisaram o curso de Licenciatura em Ciências e Engenharia em quatro universidades de Portugal, com um total de mil respondentes.

Sobre a escrita, as estratégias mais citadas foram: revisão do texto, utilização de vocabulário especializado e o uso de registros realizados em sala de aula. Sobre a leitura, as estratégias mais apontadas foram: realização de releitura e o destaque das ideias principais do texto. As estratégias menos utilizadas são: (a) na leitura e na compreensão: a troca de opiniões com os professores sobre os livros lidos, a citação de livros lidos anteriormente pelo aluno, e (b) na escrita: ajuda de terceiros para correção do texto e utilização da gramática.

Os autores sugerem que as habilidades de ler, compreender e escrever correta e claramente são fundamentais em nossa sociedade. Além disso, retratam também que tais habilidades estão relacionadas ao sucesso acadêmico, visto que os universitários que não estiverem preparados em tais quesitos encontrarão dificuldades em sua trajetória no Ensino Superior.

Corrêa (2011) defende alguns princípios que considera fundamentais para um curso que forma professores. Defende a necessidade da sistematicidade da produção escrita, uma vez que a educação básica diverge em relação aos objetivos do ensino superior e que muitas lacunas ficam em aberto. Além disso, a autora também retoma sua posição defensiva em relação à regularidade da leitura e da escrita focalizadas em todas as disciplinas do curso. 
Damiani et al (2011) apontam que a escrita é um processo complexo e que exige cuidado para tornar o texto compreensível. Assim como em meu trabalho anterior (ALMEIDA, 2013), as autoras sugerem que existe uma lacuna na Educação Básica, pois a análise das produções textuais permite concluir que pouco se aprendeu naquela etapa da educação.

O estudo das autoras foi desenvolvido na Universidade Federal de Pelotas com uma turma do quarto período do curso de Pedagogia, totalizando 44 respondentes para um instrumento de quatro perguntas que objetivavam respostas curtas. As autoras realizam um diagnóstico e análise dos problemas de escrita dos estudantes e construíram quatro categorias de dificuldades: problemas de construção frasal; impropriedade vocabular; problemas de grafia/acentuação; problemas de coesão textual; e problemas de concordância e regência verbal e nominal.

A análise revelou que as produções apresentavam um cunho impulsivo, rápido, de pouco planejamento e sem demonstrar uma aproximação maior do escrevente mediante planejamento e revisão, que, de modo geral, são aspectos essenciais para uma escrita de boa qualidade. Desse modo, as autoras apontam para a necessidade dos cursos de formação repensarem estratégias para acompanhar e melhorar o desempenho dos alunos com dificuldades, através de monitoramento, avaliação e revisão.

Abreu, Bazzo e Godoy (2013) escolheram três instituições públicas de prestígio $^{4}$ no sul do país - de forma intencional, como esclarecem - por constituírem espaços de excelência. Ao retomarem a história do Curso de Pedagogia, enfatizam a pouca importância dada à linguagem. Identificam a ausência de uma diretriz nacional para a definição de disciplinas e de carga horária relacionadas à linguagem, além de perceberem uma distribuição aleatória das mesmas nos cursos estudados. $\mathrm{O}$ caso ainda é agravado quando é constatado que, ao ser realizada uma consulta aos estudantes sobre reforma curricular de uma das instituições e os primeiros solicitarem

\footnotetext{
${ }^{4}$ As autoras não esclarecem como chegaram a tal conclusão, sua fonte.
} 
a inclusão da disciplina Produção de Textos, a própria instituição simplesmente descarta o pedido dos alunos. Afirmam que:

Considerando ainda que ele deverá ser capaz de criar situações de aprendizagem relativas à linguagem escrita, faz-se premente prepará-lo teórico e metodologicamente para saber lidar com os diversos usos da leitura e da escrita, os aspectos gráficos da linguagem escrita, os funcionais, os textuais e, sem dúvida, aqueles aspectos referentes ao sistema alfabético de representação. (ABREU, BAZZO \& GODOY, 2013, p. 344).

Assim, as autoras defendem que os cursos de Pedagogia dediquem maior tempo e espaço para a área de linguagem, principalmente por ser considerada uma área complexa. Cabe destacar que, assim como em Almeida (2013), percebem que o problema é de ordem anterior, ou seja, precedente à educação superior: está situado na Educação Básica.

Cunha e Santos (2006) realizaram um estudo em duas universidades particulares - uma em São Paulo e outra em Minas Gerais - com um total de 134 estudantes dos cursos de Administração, Psicologia, Análise de sistemas, Computação e Farmácia. As metodologias utilizadas foram: questões de identificação gerais, o procedimento $C l o z e^{5}$ e uma redação. Para este último, a banca examinadora foi composta pelas próprias autoras e mais um "juiz”, um profissional especializado para garantir a confiabilidade dos resultados. As autoras tinham como objetivo compreender as relações entre as habilidades de leitura e de escrita entre os universitários.

\footnotetext{
${ }^{5}$ De acordo com as palavras das autoras, o procedimento Cloze consiste: "na apresentação de uma seleção de prosa da qual se omitem palavras de maneira sistemática, substituídas por uma linha de extensão constante. Essas palavras omitidas devem ser recuperadas pelo leitor para restituir seu sentido completo à seleção." (CUNHA \& SANTOS, 2006, p. 238). O procedimento Cloze consiste em eliminar algumas palavras de um texto para que uma pessoa tente a reposição das mesmas no momento em que realiza a leitura. No estudo citado, Cunha e Santos (2006) utilizaram o texto Desentendimento, de Veríssimo.
} 
$\mathrm{Na}$ redação, intencionaram avaliar o "número de erros cometidos nos textos produzidos, de acordo com a norma padrão da Língua Portuguesa, no uso dos tópicos gramaticais, a saber, concordância verbal e concordância nominal e ortografia" (CUNHA \& SANTOS, 2006, p.240). Observe que os outros aspectos que envolvem a produção escrita, como a coesão e a coerência, não foram incluídos na avaliação das redações pesquisadas pelas autoras, o que demonstra a redução das habilidades de escrita a tópicos gramaticais.

Cunha e Santos (2006) constataram que quanto maior é a compreensão da leitura, menor é a possibilidade de ocorrência de erros:

\begin{abstract}
Assim, detectou-se que há problemas quanto às habilidades de compreensão de leitura e de produção escrita em universitários ingressantes e que essas habilidades se relacionam, visto que quanto menor a compreensão da leitura, maior a quantidade de erros nos tópicos gramaticais na escrita. $\mathrm{O}$ que surpreende, no entanto, é que ainda permanece o quadro dos anos 70, quando do início das pesquisas nessas áreas, e que essa situação é agravada pela escassez de pesquisas sobre leitura e menos ainda sobre escrita, principalmente no Brasil. (CUNHA \& SANTOS, 2006, p.243).
\end{abstract}

A pesquisa das autoras revelou que as produções dos estudantes estão aquém das esperadas, principalmente em relação à escrita, na qual os mesmos demonstram muitas dificuldades. Cunha e Santos (2006) concluem que os alunos necessitam de apoio, mas não sugerem nenhum tipo.

Marinho (2010), ao tratar sobre a relação de estudantes universitários de Pedagogia e a escrita acadêmica, com foco no conhecimento dos diferentes gêneros textuais sobre os quais as faculdades se debruçam, relata que existe uma atitude autodiscriminatória por parte dos estudantes, que estão sempre subestimando suas próprias capacidades frente às exigências do universo acadêmico. Se, por um lado, a mesma afirma que muitos professores não estão acostumados a explicar de forma clara suas concepções sobre a escrita e sobre o que se pretendem como objetivo, por outro lado, os mesmos se queixam sobre as produções escritas de seus discentes. Questiona a autora: 
[...] depois de algum tempo ouvindo queixas sobre "o professor que não lê" e o "professor que não escreve", percebe-se um movimento em direção a ações propositivas no campo da pesquisa e da formação de professores. Se alimentamos, de alguma forma, esses discursos, por que não nos interrogamos sobre o que fazemos ou que propomos a esses professores, nos cursos de formação, quando se trata de trabalhar com a leitura e com a escrita? Se há problemas com esse professor, em que medida as instituições de formação também são responsáveis por eles? (MARINHO, 2010, p.374)

Uma pesquisadora que realizou um estudo semelhante ao objeto de estudo deste trabalho foi Leta (2005), que conseguiu constatar dados similares. Em seu estudo, a autora revela: "a referência a alunos despreparados e com comportamento inadequado para um futuro professor se fez presente tanto no depoimento dos professores quanto dos profissionais das equipes técnico-pedagógicas". Ao mesmo tempo, complementa a ideia anterior afirmando que também nota que os próprios professores do Curso apresentam um discurso bastante reflexivo e interventor, porém diferente e contraditório de suas práticas pedagógicas (LETA, 2005, p. 213).

\subsection{O papel do professor em sala de aula: o domínio da norma padrão e de habilidades de escrita}

Nesta seção, buscamos apontar que o estudante de graduação de Pedagogia, futuro professor, precisa dominar habilidades de escrita para uma prática docente significativa e de qualidade. Apesar do foco das apresentações estar concentrado principalmente em aspectos da norma padrão, principalmente devido à literatura da área, acreditamos que a escrita envolve habilidades de várias ordens, conforme será demonstrado nas seções posteriores.

Possenti $(1996,2011)$ aponta que o papel da escola é ensinar a norma padrão ou, ao menos, criar as condições necessárias para que ela possa ser aprendida. Para o autor, a norma padrão é "de fato o dialeto dos grupos sociais mais favorecidos", e a 
imposição do aprendizado de uma única forma linguística pode ser considerada uma violência cultural. Por isso, defende-se o processo de ensino-aprendizagem valorizando todos os dialetos e formas, normas, destacando, certamente, qual é a mais prestigiada e o porquê, visto que não existe nenhuma razão para não se ensinar a norma padrão. Desse modo, será determinada e estabelecida uma norma padrão de escrita, que é a mais complexa e que vai ser perpetuada pelas escolas e que abraçará o domínio de várias convenções. Nesse processo, o domínio do professor para o ensino é fundamental.

Geraldi (2011) também defende que cabe ao professor oportunizar aos alunos atividades que permitam que se apropriem da norma padrão, mas sem que isso signifique o desprestígio das demais variações. Para Zuin e Reyes (2010, p.94) “cabe aos professores trabalhar com a variação dialetal de forma a não prestigiar a língua culta, mas ensinar aos alunos tais variações, enfatizando o poder que há por trás do dialeto culto e por que a escola deve também ensiná-lo”. Elas defendem também que os professores devem ensinar as normas ortográficas, visto que existem muitas variações na oralidade, diferentemente da escrita!

Paulo Freire, em entrevista para Zaccur (1999, p.17) já dizia que "é indispensável que a professora testemunhe ao menino popular que o jeitão dele dizer as coisas também faz sentido, é bonito e tem sua própria gramática, ainda que ela lhe ensine outra forma de falar e escrever".

Ao indicar que a atuação do professor deve se remeter às regulamentações oficiais da língua sobre a escrita espontânea do aluno, Soares (1999), tratando da alfabetização menciona que ele precisa partir do conhecimento sobre os contextos da criança para poder compreender e atuar na intervenção da escrita, tendo consciência das relações entre os sistemas ortográfico e fonológico. Soares (1999, p. 73) destaca ainda "o papel fundamental que tem a professora na orientação do processo de apropriação da escrita pela criança, conduzindo-a da exploração livre dos recursos de representação dos sons da fala à regulamentação que a ortografia impõe ao uso dos símbolos". 
Conforme será enfatizado na seção 4.7. (Relação com a Educação Básica), poderemos perceber um grande embate nesse quesito. Se por um lado, temos as recomendações que os professores precisam seguir, conforme Soares (1999) sugeriu acima, por outro lado, percebemos que os estudantes chegam à universidade com algumas falhas decorrentes da escolarização básica, o que certamente irá afetar o seu desempenho acadêmico. E muitos desses alunos irão se graduar e atuar com falhas semelhantes àquelas que apresentavam na Educação Básica.

Soares (1999) e Bagno (2013) concordam que o domínio de metalinguagem, de aspectos técnicos e teóricos cabe ao professor. $\mathrm{O}$ aluno deve ser um bom usuário dos recursos linguísticos que lhe são apresentados. Os profissionais habilitados que devem ser os técnicos em Língua são os professores, conforme sustenta Bagno (2013). Afirma o autor que "nós, sim, professores, temos que conhecer profundamente o hardware da língua, a mecânica do idioma, pois nós somos os instrutores, os especialistas, os técnicos. Mas não os nossos alunos” (BAGNO, 2013, p. 145).

Bechara (2006) aponta que a crise existente na escola ocorre justamente quando se extingue a gramática normativa da perspectiva de uma "nova educação", que privilegia o "coloquial”. A gramática normativa é um instrumento auxiliador na prática da educação linguística, que deve sim reconhecer a "bagagem cultural" dos educandos, mas de modo algum sem proporcionar-lhes um contato igual com a norma padrão. Bechara (2006) sugere que o ensino da gramática normativa é válido sim, de modo a integrar-se à linguagem dominada, mas nunca de modo soberano. Afirma Bechara (2006):

Ora, a educação linguística põe em relevo a necessidade de que deve ser respeitado o saber linguístico prévio de cada um, garantindo-lhe o curso na intercomunicação social, mas também não lhe furta o direito de ampliar, enriquecer e variar esse patrimônio inicial. As normas da classe dita "opressora" e "dominante" não serão nem melhores nem piores, ou as normas da língua literária não serão nem melhores nem piores do que as usadas na língua coloquial. (BECHARA, 2006, p.12) 
Apesar de Bechara (2006) atribuir grande importância à gramática normativa, em momento algum o autor desconsidera outros aspectos essenciais para a produção de textos. Aliás, de fato, escrever, principalmente na universidade, exige um conjunto de habilidades linguísticas e textuais que vão além de habilidades gramaticais. A Educação Linguística, conforme proposta pelo autor, centrada na competência linguística do aluno acarretará em modificações no 'currículo tradicional', que é classificado por Bechara (2006, p.23) como "antieconômico, banal e inatural e, por isso mesmo, improdutivo".

Geraldi (2011, p. 39) também observa essa crise e afirma que existe um "baixo nível de desempenho linguístico demonstrado por estudantes na utilização da língua, quer na modalidade oral, quer na modalidade escrita" e indica que a norma padrão foi eleita como tal devido a fatores históricos que determinaram sua forma como a mais importante e consideraram as outras como insatisfatórias. Isso é fato! Ainda assim, cabe ao professor ensinar a norma padrão, mas ao mesmo tempo sem depreciar as outras formas. A linguagem é entendida como sinônimo de poder e é essencial que o professor oportunize tal forma aos seus alunos. Certamente, esse processo de ensinoaprendizagem requer o domínio, por parte do professor, do que leciona.

Nesse sentido, Libâneo (2013) afirma que:

O ensino de português é uma das mais importantes responsabilidades profissionais do professor, pois é condição para a aprendizagem das demais disciplinas, além de ser instrumento indispensável para a participação social dos indivíduos em todas as esferas da vida: profissional, política e cultural. (LIBÂNEO, 2013, p 46)

Bagno (2013) também menciona essa questão da aprendizagem nas demais disciplinas e assevera que a área da Língua Portuguesa, e também da Matemática, lida com "competências, faculdades e habilidades cognitivas, com processos mentais, com fenômenos de ordem biológica: todo ser humano nasce pronto para falar uma língua e para realizar operações numéricas" (BAGNO, 2013, p.87) e que, a partir daí, as 
outras matérias serão aprendidas a partir do domínio que uma pessoa tem das duas primeiras áreas citadas, visto que todos os conteúdos "são transmitidos por meio da linguagem" (BAGNO, 2013, p. 87). Libâneo (2013) comenta sobre a relação entre domínio de conhecimentos e ensino:

Evidentemente, as mesmas expectativas que o professor tem em relação do desenvolvimento intelectual dos alunos aplicam-se a ele próprio. Não se pode exigir dos alunos o domínio sólido de conhecimentos se ele próprio não domina com segurança a disciplina que ensina; não pode exigir dos alunos o domínio de métodos de estudos, das formas científicas de raciocinar e hábitos de pensamento independente e criativo, se ele próprio não os detém. (LIBÂNEO, 2013, p 78)

Para Libâneo (2013), é essencial que o professor domine a área com a qual irá trabalhar, pois a falta de domínio prejudicará o diálogo em sala de aula sobre dúvidas que venham a surgir. O mesmo autor, sobre as relações professor-aluno, aponta como um dos aspectos cognoscitivos da interação o emprego da norma padrão por parte do professor, pois a utilização inadequada pode influenciar negativamente no desenvolvimento do aluno.

É de extrema importância que o professor domine a norma padrão da Língua Portuguesa e suas variedades linguísticas. Bechara (2006), Gnerre (2009) e Bagno (2013) são autores que discutem a relação entre linguagem e poder, enfatizando a questão do preconceito linguístico.

Para Gnerre (2009), a língua padrão esta ao alcance apenas de uma parcela reduzida da população e relacionada a valores sociais. O autor afirma que a diferenciação entre língua padrão e não padrão ocorre por vários motivos, como: a correlação com a escrita, a tradição gramatical e também a tradição cultural. Se observarmos o trecho abaixo, será possível notar como Gnerre (2009) percebe as relações sociais em torno da norma padrão:

$\mathrm{Na}$ variedade padrão, então, são introduzidos conteúdos ideológicos, relativamente simples de manipular, já que as formas 
às quais estão associados ficam imobilizadas, favorecendo, assim, quase que uma comunicação entre grupos de iniciados que sabem qual é o referente conceitual de determinadas palavras e, assegurando que as grandes massas, apesar de familiarizadas com as formas das palavras, fiquem, na realidade, privadas do conteúdo associado (GNERRE, 2009, p. 20).

Observe-se que, para Gnerre (2009), a linguagem é utilizada como forma de poder, na qual um grupo minoritário exerce grande influência sobre um grupo majoritário; tem uma função social, mas reafirma que existe uma divisão social completamente discriminatória. Dessa forma, o linguista explicita um duplo papel: "a começar do nível mais elementar das relações com o poder, a linguagem constitui o arame farpado mais poderoso para bloquear o acesso ao poder" (GNERRE, 2009, p. 22)

Por vezes é surpreendente que quando um sujeito surge em defesa da manutenção da norma padrão, tanto nas escolas quanto nas universidades, aparecem em maior intensidade as críticas a essa perspectiva. As alegações podem ser reduzidas a uma única palavra: preconceito ou desprestígio. Essa é a grande falácia de nossa sociedade e do nosso sistema educacional. Conforme afirma Bechara (2006), "hoje, por um exagero de interpretação de "liberdade" e por um equívoco em supor que uma língua ou uma modalidade é "imposta" ao homem, chega-se ao abuso inverso de repudiar qualquer outra língua funcional, que não seja aquela coloquial, de uso espontâneo na comunicação cotidiana" (BECHARA, 2006, p. 14).

Apesar de apresentar um contundente discurso sobre o preconceito linguístico que cerca toda a nossa população, explicitando alguns mitos sobre nossa língua, Bagno (2013) esclarece que existe uma grande diferença entre o domínio da língua do aluno em contraposição à do professor, conforme exposto anteriormente.

Soares (2001, p.9) explica que a escola brasileira é "antes contra o povo que para o povo" devido ao enorme número de repetência, evasão e abandono que vem sofrendo, principalmente no que diz respeito às camadas populares. A autora fornece três explicações para tal. A primeira é a ideologia do dom, que consiste no 
oferecimento de oportunidades de igualdades por parte da escola, dependendo o sucesso das qualidades (intelectuais, cognitivas) do aluno. A segunda é a ideologia da deficiência cultural, que preconiza que o fracasso do aluno advém de se contexto social e familiar, demonstrando a superioridade das camadas dominantes do ponto de vista econômico, social e cultural. A terceira é a ideologia das diferenças culturais, a qual realiza uma comparação de um indivíduo com o modelo ideal da sociedade dominante, culminando no fracasso do aluno diferente.

Como Soares (2001, p.17) destaca, "a escola usa e quer ver usada a variantepadrão socialmente prestigiada". Como os outros intelectuais aqui apresentados afirmam, essa é uma medida necessária. O trabalho de Soares (2001) é uma referência de peso quando discutimos a linguagem. Porém, percebe-se que a preocupação da autora é referente à exclusão das camadas populares socialmente desprivilegiadas. A autora não trata sobre a formação de professores e a importância desta para a atuação docente. Suas considerações também nos permitem observar que a mesma também realiza uma referência sobre a constituição de um aluno poliglota dentro da sua própria língua:

Um ensino da língua materna comprometido com a luta contra as desigualdades sociais e econômicas reconhece, no quadro dessas relações entre a escola e a sociedade, o direito que têm as camadas populares de apropriar-se do dialeto de prestígio, e fixa-se como objetivo levar os alunos pertencentes a essas camadas a dominá-lo, não para que se adaptem às exigências de uma sociedade que divide e discrimina, mas para que adquiram um instrumento fundamental para a participação política e a luta contra as desigualdades sociais. (SOARES, 2001, p. 78)

Possenti (2011), nesse sentido, destaca que o valor que é atribuído a determinado tipo de linguagem varia conforme os usuários típicos daquele espaço. Ou seja, cada uso poderá ser adequado ou não em um ambiente específico, o que aponta para a necessidade do domínio múltiplo. O mesmo autor ainda explica que a opressão, ou supressão, está presente em nossa sociedade e que, a liberdade consiste verdadeiramente na possibilidade de escolhas de um indivíduo. Para Bechara (2006): 
[...] haverá opressão em "impor", indistintamente, tanto a língua funcional da modalidade culta a todas as situações de uso da linguagem, como a língua funcional da modalidade familiar ou coloquial, nas mesmas circunstâncias, a todas as situações de uso da linguagem, pois que ambas as atitudes não recobrem a complexa e rica visão da língua como fator de manifestação da liberdade de expressão do homem. (BECHARA, 2006, p. 15).

O conceito de educação linguística em Bechara (2006) consiste na compreensão de que a função primordial da educação escolar formal é transformar um indivíduo em um poliglota, dentro da Língua Portuguesa. Nessa perspectiva, acredita-se que o professor precisa ter uma formação adequada, que permita ao aluno alcançar essa complexidade de sua utilização. Prossegue o mesmo autor assegurando que a nossa Língua é um diassistema, ou seja, "um conjunto mais ou menos complexo de "dialetos" (variedades diatópicas), de "níveis de língua” (variedades diástricas) e de “estilos" (variedades diafásicas)" (BECHARA, 2006, p. 55).

Ao acreditar na promoção da cultural integral do aluno, Bechara (2006) também reflete sobre o papel do professor universitário da área de Letras ou Pedagogia, que precisa estimular o aluno a engajar-se em uma atividade de constante atualização e busca de informações, essenciais a sua prática como docentes. Espera-se que o aluno se torne um cidadão de participação ativa na sociedade, com capacidades múltiplas de utilização da Língua e também com qualidades de um eterno aprendiz.

\subsection{Processamento cognitivo da escrita}

A escrita precisa ser pensada como um processo, não apenas como um produto. Escrever é um processo cognitivo complexo, que envolve um conjunto de subprocessos e a ativação de conhecimentos de vários tipos.

As contribuições da Psicolinguística, através das pesquisas de Linda Flower e John Hayes acerca do processamento cognitivo da escrita em seu modelo inicial, nos ajudam a refletir sobre esses aspectos. Optamos por apresentar o modelo de Flower e 
Hayes da década de 80 por ele ter sido a base dos modelos processuais da escrita posteriores, os quais mantiveram, de modo geral, a caracterização dos processos envolvidos na escrita, conforme proposta pelos autores. Nosso objetivo ao fazermos referência a esse modelo é ampliar o campo de investigação ao indicar em sua análise em quais estágios do processamento os alunos apontam a concentração das dificuldades.

De acordo com Lopes (2011), o modelo proposto por Flower e Hayes, em 1980, caracteriza-se como pioneiro no campo do processamento da escrita, pois "procuraram capturar em sua esquematização tanto os subprocessos envolvidos na composição de um texto como também a maneira como esses subprocessos estão organizados, descrevendo também as diferenças individuais em estilos de composição" (LOPES, 2011, p.32).

O modelo de processamento cognitivo proposto por Flower e Hayes na década de 80 se assenta em torno de três pontos principais: o contexto da tarefa; a memória de longo prazo; e o processo da escrita ${ }^{6}$. Apesar de apresentar uma ordem, essa estrutura não é inflexível e hierárquica. Ao contrário, os autores sugerem em todo momento que este é um processo que não tem características linearmente rígidas. Observe:

\footnotetext{
${ }^{6}$ As nomenclaturas utilizadas podem variam conforme o autor, apesar do significado ser o mesmo.
} 


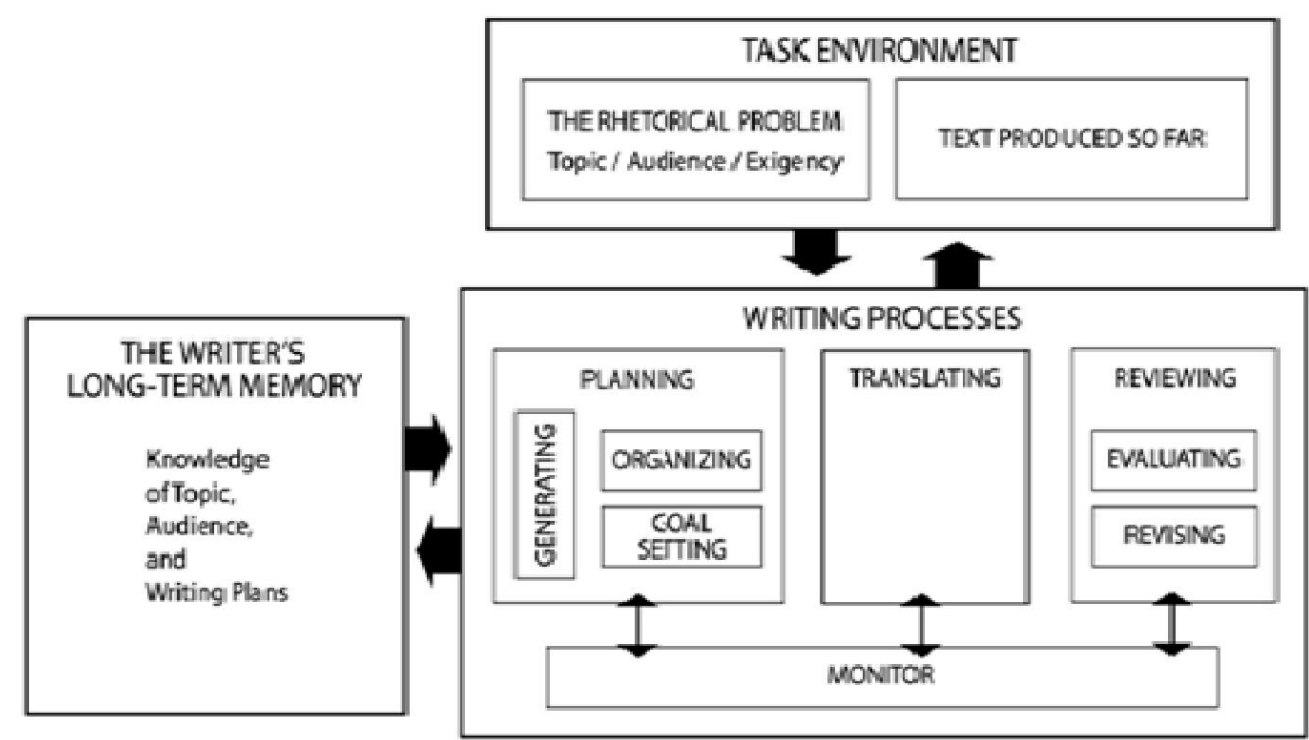

Figura 1: Modelo processual da escrita reproduzido de Flower \& Hayes (1981, p.370).

O primeiro componente - contexto da tarefa - inclui os aspectos que são externos ao escritor e influenciam o processo. São eles: a descrição da tarefa, os tópicos a serem abordados, a motivação, a audiência (público alvo) e o que foi produzido até então, visto que, de acordo com Lopes (2011, p. 32), "à medida que vai sendo produzido, esse texto torna-se input, um elemento externo à mente do escritor, que exige a continuidade e interfere na produção a partir daquele momento.”.

O problema retórico está contido nesta parte e constitui-se como um dos aspectos mais importantes. De acordo com Flower e Hayes (1981, p. 369), "it includes not only the rhetorical situation and audience which prompts one to write, it also includes the writer's own goals in writing",", ou seja, é um aspecto que está relacionado aos objetivos próprios do escritor.

O segundo componente é a memória de longo prazo, que contém todo o conhecimento que uma pessoa tem acerca de um assunto. Flower e Hayes (1981, p.371) apontam que é um "storehouse of knowledge about the topic and the audience,

\footnotetext{
${ }^{7}$ Tradução: "Isso inclui não apenas a situação retórica ou a audiência que motiva alguém a escrever, isso também inclui os objetivos próprios do escritor na escrita”.
} 
as well as knowledge of writing plans and problem representations"8. Este é um componente mais subjetivo e individual, que está relacionado à dimensão intelectual e cognitiva de uma pessoa.

O terceiro componente é o processo da escrita e está subdividido em três partes: o planejamento, a tradução e a revisão. O planejamento é um momento um pouco mais abstrato, no qual o escritor mentaliza, idealiza, internamente, tudo o que irá realizar. É uma etapa que envolve vários subprocessos, como a elaboração de ideias, a organização das ideias e o estabelecimento de objetivos. Aliás, é interessante ressaltar que os objetivos têm um papel importante nesse sistema, pois são eles que irão liderar todo o processo, possibilitando movimentos de correção e coordenação.

A tradução, apesar de tal nomenclatura, diz respeito ao próprio momento de escrita, de elaboração, de confecção do texto. Flower e Hayes (1981, p. 373) indicam que "this is essentially the process of putting ideas into visible language". Lopes (2011) indica que

[...] corresponde à geração de sentenças e envolve transpor as ideias selecionadas na etapa de planejamento para um plano mais concreto, o da sentença propriamente dita. É o momento em que o texto começa a tomar forma no papel e as ideias são efetivamente realizadas no plano da escrita. (LOPES, 2011, p.33)

A última subetapa é a revisão, de caráter avaliativo, que envolve os procedimentos de releitura e edição. Para Flower e Hayes (1981), a revisão, em si, é um processo consciente no qual o escritor "volta" ao seu texto com um olhar mais avaliativo. Entretanto, isso não significa que este seja um momento isolado. Ao contrário, é um aspecto que pode ocorrer mediante uma situação não planejada, na qual, por exemplo, o escritor revê e reavalia alguma parte antes mesmo do processo estar concluído. Sugerem os autores:

\footnotetext{
${ }^{8}$ Tradução: "espaço de armazenamento de conhecimentos sobre o tópico e a audiência, assim como o conhecimento dos planos de escrita e as representações do problema".

${ }^{9}$ Tradução: "esse é essencialmente o processo de colocar ideias em uma linguagem visível”.
} 
Reviewing, itself, may be a conscious process in which writers choose to read what they have written either as a springboard to further translating or with an eye to systematically evaluating and/or revising the text. These periods of planned reviewing frequently lead to a new cycles of planning and translating. However, the reviewing process can also occur as an unplanned action triggered by an evaluation of either the text or one's own planning (that is, people revise written as well as unwritten thoughts or statements). (FLOWER \& HAYES, 1981. p. 374) ${ }^{10}$

Lopes (2011) reforça um ponto essencial desta etapa de revisão, indicando que o "processamento da revisão se dá com o objetivo de aprimorar o texto tanto no plano do conteúdo (adequação das ideias, clareza de significados etc.) quanto no das convenções de uso da língua (correção gramatical, eficácia discursiva etc.)". Acrescenta ainda que a etapa de revisão é um "processo mais profundo, com o objetivo claro de aprimorar o que se produziu, através de uma análise focada, específica, em consonância com os objetivos definidos no planejamento" (LOPES, 2011, p. 36).

Toda essa etapa é supervisionada pela figura do monitor, que se caracteriza por uma autofunção. Ele está presente em todo o sistema, mais fortemente influente no processo da escrita. Sugerem Flower e Hayes (1981, p. 374): “As writers compose, they also monitor theirs current process and progress. The monitor functions as a writing strategist which determines when the writer moves from one process to the next"11. Os mesmos ainda acrescentam que, através de suas pesquisas, puderam

10 Tradução: "A revisão, propriamente dita, pode ser um processo consciente no qual escritores escolhem ler o que eles já escreveram como um trampolim para favorecer a tradução ou olhar sistematicamente para avaliar e/ou revisar um texto. Esses períodos de revisão planejados frequentemente conduzem a novos ciclos de planejamento e tradução. No entanto, o processo de revisão também pode ocorrer como uma ação não planejada despertada por uma avaliação do texto ou pelos planejamentos próprios de alguém (isto é, pessoas revisam pensamentos ou enunciados escritos assim como não escritos)".

${ }^{11}$ Tradução: "Quando escritores compõem, eles também monitoram seus processos e progressos. O monitoramento funciona como uma estratégia de escrita que determina quando o escritor se movimenta de um processo para o próximo. 
inferir que tais escolhas são determinadas tanto pelos objetivos do escritor, quanto por seu estilo.

Garcez (2012) reforça essa visão da escrita como processo, e ainda acrescenta que "compreende-se que a escrita é uma atividade que envolve várias tarefas, às vezes sequenciais, às vezes simultâneas" (GARCEZ, 2012, p. 14). A mesma autora ainda reforça tal perspectiva ao concluir que durante a escrita, "há também idas e vindas: começa-se uma tarefa e é preciso voltar a uma etapa anterior ou avançar para um aspecto que seria posterior" (idem, p. 14).

A título de síntese, pode-se afirmar que o modelo de processamento cognitivo da escrita proposto por Flower e Hayes (1981) reside em quatro pontos principais. O primeiro aspecto refere-se ao processo de escrita como sendo melhor compreendido como um processo cognitivo especial, no qual os escritores 'movimentam-se internamente' durante o momento da própria escrita ao fazerem suas escolhas, como por exemplo: dar uma pausa durante a escrita de um texto para verificar como determinado tópico foi tratado anteriormente. O segundo aspecto indica que o processamento tem uma estrutura hierárquica e recursiva, na qual qualquer processo pode ser articulado a outro. Nesse sentido, o modelo distingue-se de outros que assumem estágios, em uma sequência temporal determinada, sem operações recursivas. O terceiro ponto faz referência aos objetivos, sugerindo que os mesmos são criados na medida em que se escreve, durante todo o processo. $\mathrm{O}$ último ponto mostra que os escritores trabalham com seus objetivos por dois caminhos: sustentando os objetivos principais e optando por elaborar sub-objetivos ou então através da substituição total dos objetivos principais. Observe que todos esses quatro pontos se entrelaçam e nos ajudam a perceber a complexidade e amplitude do modelo proposto pelos estudiosos.

E como estudar esse processamento? Flower e Hayes (1981) apontam que existem várias formas de realização. Em seu estudo inicial, os autores fizeram uso de protocolos verbais que consistiam na seguinte tarefa: durante a produção escrita, o “autor" utilizaria um recurso pessoal para exprimir suas ações: a voz. Tudo o que ele 
estivesse pensando, ele deveria registrar (falando alto) para fins de análise. $O$ protocolo, dessa forma, surgia a partir da transcrição desse trabalho ${ }^{12}$.

Nesse sentido, por exemplo, Lopes (2011) utilizou o software Camtasia, uma ferramenta computacional que permite capturar o que ocorre na tela do computador. $\mathrm{O}$ autor gravou toda a produção dos participantes de sua pesquisa enquanto estes realizavam uma dada tarefa de escrita e depois analisou os vídeos gerados. Mais recentemente também têm sido empregados outros recursos para registrar o processo de escritura, como o Translog ou o Inputlog, softwares que gravam todos os movimentos do teclado realizados pelo escritor durante a produção de um texto.

No presente trabalho, entre outros aspectos, buscamos identificar, a partir das falas dos alunos entrevistados, como estes viam seu processo de escritura, a que componentes desse processo faziam referência, quais os aspectos que lhes traziam mais dificuldade, bem como o que era enfatizado pelos professores em suas aulas. $\mathrm{O}$ modelo processual proposto por Flower \& Hayes (1981) servirá, pois, de referência para essa caracterização entendendo-se, no entanto, que, além da dimensão cognitiva, a escrita envolve outras dimensões igualmente relevantes - emocional, social etc. $\mathrm{Na}$ próxima seção, a dimensão social e aspectos motivacionais poderão ser abordados, conforme os dados obtidos.

\subsection{Qualidades de um bom texto e habilidades de escrita}

Se houve um tempo em que era comum a existência de comunidades ágrafas, se houve um tempo em que a escrita era de difícil acesso ou uma atividade destinada a alguns poucos privilegiados, na atualidade, a escrita faz parte da nossa vida, seja porque somos constantemente solicitados a produzir textos escritos (bilhete, e-mail, lista de compras, etc.), seja porque somos solicitados a ler textos escritos em diversas situações do dia-a-dia

\footnotetext{
${ }^{12}$ Além dos protocolos verbais, outros métodos têm sido usados na investigação do processamento da escritura. Esses métodos buscam capturar aspectos menos conscientes, já que se pautam no registro e análise das ações do próprio escritor e não exclusivamente em seu relato.
} 
(placas, letreiros, anúncios, embalagens, e-mail, etc.). (KOCH \& ELIAS, 2015, p.31)

Para Marcuschi (2010), a escrita

seria um modo de produção textual-discursiva para fins comunicativos com certas especificidades materiais e se caracteriza por sua constituição gráfica, embora envolva também recursos de ordem pictórica e outros (situa-se no plano dos letramentos). Pode manifestar-se, do ponto de vista de sua tecnologia, por unidades alfabéticas (escrita alfabética), ideogramas (escrita ideográfica) ou unidades iconográficas, sendo que no geral não temos uma dessas escritas puras (MARCUSCHI, 2010, p. 26)

Para Leta (2005), a escrita é um conjunto de habilidades linguísticas e psicológicas, que vão desde a habilidade de registrar um som até a habilidade de conseguir transmitir um significado para um leitor. A autora menciona que somos fortemente influenciados pela escrita. Estamos cerceados, desde o advento da imprensa, por registros escritos de todos os tipos: registros de sentimentos, convenções, entre outros.

Diante dessa imersão no mundo escrito, surgem alguns mitos acerca da compreensão sobre em que consiste a produção de textos escritos, mas ao invés de apontarmos neste trabalho alguns mitos sobre essa produção, decidimos fazer o oposto e indicar algumas verdades sobre a escrita, conforme Garcez (2012). Para a autora, escrever:

$\checkmark$ é um ato trabalhoso, não espontâneo;

$\checkmark$ exige estudo sério e muita prática;

$\checkmark$ é uma prática que se articula com a leitura;

$\checkmark$ é necessário no mundo atual;

$\checkmark$ é uma habilidade - que pode ser desenvolvida; e

$\checkmark$ é vinculado a práticas sociais.

No curso de Pedagogia, alguns serão formados e outros já são professores que vão atuar e intervir no processo de ensino e aprendizagem da língua escrita padrão. É 
necessário estar bem preparado para essa intervenção. Alves (2014, p.15) afirma que "escrever melhor de maneira objetiva e atraente é o grande objetivo de quem lida profissionalmente com a palavra".

A partir das considerações realizadas anteriormente sobre as dificuldades que muitos alunos de graduação têm com a escrita, a necessidade do domínio por parte do professor, atual estudante, da Língua Portuguesa e com a compreensão básica sobre como uma mente processa um texto, consideramos necessário indicar em que consiste um bom texto, uma boa escrita.

O que pode ser considerado um bom texto? Quais são os elementos fundamentais que constituem um texto de qualidade? Para nos ajudar a responder tais questões, Marcuschi (2010), Garcez (2012), Faraco e Tezza (2014), Koch e Travaglia (2013) e Koch (2014) irão nos guiar nesse percurso. Entretanto, cabe destacar que estudiosos como Russell, em entrevista para Ramos e Espeiorin (2009), afirmam que não existe um modelo fixo para definir uma boa escrita, apenas um conjunto de regras que podem auxiliar um escritor. Disse ele:

Infelizmente, não existe receita, somente aquilo que chamamos "regras gerais", que não são algoritmos nem regras fixas; mas, que, pelo contrário, estão apenas "estabilizadas por ora", até haver alguma mudança nas condições. Isso não significa que a escrita acadêmica não possa ser ensinada de forma explícita. Mas se for ensinada como receita e não como repertório de estratégias, uma caixa de ferramentas e recursos, então ela se torna enfadonha e insípida. (RAMOS \& ESPEIORIN, 2009, p. 245)

Então, para começar, questiona-se: como se constrói um texto? Garcez (2012) explica que essa construção ocorre e possui sentido dentro de uma prática social, a partir de uma motivação inicial.

O componente motivacional varia entre indivíduos e os contextos nos quais estão inseridos. Em uma pesquisa para um trabalho de conclusão de curso, por exemplo, é necessário que um aluno problematize alguma inquietação, alguma lacuna que o perturbe e que o motive a descobrir, a estudar determinado fato. Na escritura de poemas, um dos componentes que surge na maioria das vezes é o próprio prazer de 
escrever. Pode ser também por uma necessidade de registrar um ponto de vista ou de defender uma opinião. São vários os exemplos que cabem nessa situação. A atribuição de sentido, de significado, é essencial para a construção de um texto, de acordo com Garcez (2012).

A partir de tal motivação, um escritor já consegue cognitivamente desenhar a estrutura de seu trabalho, que irá conter: assunto, objetivos, público-alvo, tipo de linguagem, formatação e gênero textual (GARCEZ, 2012, p. 15). Essa é a base sobre a qual se assentará todo o desenvolvimento do trabalho. Dentre todos os itens, os objetivos constituem o princípio norteador de toda a tarefa. Como explicado em tópico anterior, a partir do monitoramento de toda a atividade, o escritor precisa estabelecer movimentos recursivos de modo a compatibilizar seus escritos com os objetivos previamente selecionados.

Mas será que todos podem escrever bem? Garcez (2012, p.1) responde tal pergunta: "embora seja uma das tarefas mais complexas que as pessoas chegam a executar na vida, principalmente porque exige muito envolvimento pessoal e revelação de características do sujeito, todos podem escrever bem”.

Faraco e Tezza (2014) questionam qual é a primeira qualidade de um texto bem escrito e respondem: clareza! Qualquer tipo de texto, seja ele formal ou informal, precisa ter essa característica fundamental, que irá permitir aos leitores a compreensão significativa da informação. Conceituam a qualidade de um texto bem escrito como

[...] diretamente ligada a aspectos que ultrapassam os limites do que se costuma chamar sistema da língua. Isto é, não basta que o texto obedeça às regras de uma gramática normativa, que as palavras estejam corretamente grafadas, que as leis de concordância padrão sejam seguidas etc. Porque, afinal de contas, o texto em si não é nada! Ele é, de fato, uma ponte entre dois (ou mais) interlocutores. A organização interna do texto só tem sentido com relação à organização externa do enunciado, por assim dizer; como a língua só existe em função de seus usuários, a qualidade de um texto escrito só pode ser medida em relação à intenção de quem escreve, ao universo de que lê e ao assunto de que se fala (FARACO \& TEZZA, 2014, p. 148-149). 
Os autores ainda acrescentam que a língua padrão não é uniforme, pois existem variações geográficas, níveis de formalidade, diferenças estilísticas e diferenças entre a linguagem oral e a escrita que demonstram que a língua admite determinadas variações, conforme o contexto no qual se enquadra. Nesse sentido, Faraco e Tezza (2014) estabelecem relações entre fala e escrita e relatam no que consiste escrever bem:

[...] grande parte das diferenças entre linguagem oral e linguagem escrita decorre das especificidades de cada uma das modalidades da língua. Ter consciência clara dessas especificidades é um passo importante para se escrever bem, uma vez que escrever não é simplesmente "imitar a fala", mas reformulá-la em outra gramática. (FARACO \& TEZZA, 2014, p. 111).

Koch e Travaglia (2013), em uma perspectiva mais técnica, apresentam um primeiro elemento que consideram essencial na construção de um bom texto: a coerência. De acordo com os autores, a coerência depende de alguns fatores, dentre os quais: combinação de elementos linguísticos no texto; conhecimentos prévios; e o tipo de texto que se escreve.

Koch e Travaglia (2013) acrescentam outro elemento importante para um bom texto, chamado coesão. Afirmam que "a coesão textual, mas não só ela, revela a importância do conhecimento linguístico (dos elementos da língua, seus valores e usos) para a produção do texto e sua compreensão e, portanto, para o estabelecimento da coerência" (KOCH \& TRAVAGLIA, 2013, p. 14). Observe que, enquanto a coerência aparenta ser uma ação implícita, a coesão tende a ser mais explícita. Os próprios autores ratificam essa percepção:

Como vimos, a coerência é subjacente, tentacular, reticulada, não linear, mas, como bem observa Charolles (1978), ela se relaciona com a linearidade do texto. Isto quer dizer que a coerência se relaciona com a coesão do texto, pois por coesão se entende a ligação, a relação, os nexos que se estabelecem entre os elementos que constituem a superfície textual. Ao contrário da coerência, que 
é subjacente, a coesão é explicitamente revelada através de marcas linguísticas, índices formais na estrutura da sequência linguística e superficial do texto, o que lhe dá um caráter linear, uma vez que se manifesta na organização sequencial do texto. $(\mathrm{KOCH} \&$ TRAVAGLIA, 2013, p. 47).

Definir coerência e coesão é uma tarefa árdua, com uma multiplicidade de interpretações. Ainda sim, Koch e Travaglia (2013) conseguem estabelecer uma conceituação, declarando que

a coerência está diretamente ligada à possibilidade de se estabelecer um sentido para o texto, ou seja, ela é o que faz com que o texto faça sentido para os usuários, devendo, portanto, ser entendida como um princípio de interpretabilidade, ligada à inteligibilidade do texto numa situação de comunicação e à capacidade que o receptor tem para calcular o sentido deste texto. Este sentido, evidentemente, deve ser do todo, pois a coerência é global. (KOCH \& TRAVAGLIA, 2013, p. 21).

Koch (2014, p.17) sustenta que "a coerência, responsável pela continuidade dos sentidos no texto não se apresenta, pois, como mero traço dos textos, mas como resultado de uma complexa rede de fatores de ordem linguística, cognitiva e interacional". Ainda tratando sobre coerência, Koch e Travaglia (2013) definem alguns fatores constituintes sobre esse aspecto da escrita que estão inter-relacionados, sendo eles:

* elementos linguísticos, composto por palavras e estruturas sintáticas;

* conhecimento de mundo, de caráter individual;

* conhecimento compartilhado, de caráter coletivo, comum a ambos os interlocutores;

* capacidade de realizar inferências;

* fatores de contextualização - contextualizadores, perspectivos e prospectivos;

* situacionalidade, ou seja, adequação do texto à situação comunicativa; 
* informatividade, que diz respeito ao grau de previsibilidade ou expectabilidade da informação a ser transmitida;

* focalização, visão comum entre os interlocutores quanto aos objetivos que possuem;

* intertextualidade (marcas de outros textos) - de forma ou de conteúdo;

* intencionalidade $\mathrm{x}$ aceitabilidade; e

* consistência x relevância.

Para Koch e Travaglia (2013),

a relação da coesão com a coerência existe porque a coerência é estabelecida a partir da sequência linguística que constitui o texto, isto é, os elementos da superfície linguística é que servem de pistas, de ponto de partida para o estabelecimento da coerência. A coesão ajuda a estabelecer a coerência na interpretação dos textos, porque surge como uma manifestação superficial da coerência no processo de produção desses mesmos textos [...] embora a coesão auxilie no estabelecimento da coerência, ela não é garantia de se obter um texto coerente. (KOCH, 2013, p.49)

Ao tratar sobre essa relação entre coesão e coerência, Koch (2014) escreve que, em textos de cunho científicos, por exemplo, a coesão é um elemento "altamente desejável, como mecanismo de manifestação superficial da coerência”. A autora ainda realiza uma categorização da coesão em referencial e sequencial, porém, devido à amplitude e tecnicidade da área, decidimos não explorá-las aqui.

Em consonância com as funcionalidades da coesão e da coerência está o princípio da organização, definido por Faraco e Tezza (2014) como aspecto universal das línguas. Os autores relatam que, às vezes, pouco se sabe sobre regras de organização de palavras ou grupo de palavras, mas que de algum modo essa ordenação ocorre na composição dos textos.

A releitura de um texto produzido também é essencial para a produção de um texto de qualidade, conforme sugerem Garcez (2012) e Flower e Hayes (1980). O 
processo de revisão, que pode ocorrer a qualquer momento durante uma produção e também deve ocorrer ao final do produto, permite ao escritor reavaliar toda a sua produção em face dos seus objetivos previamente estipulados. Garcez (2012) lista uma série de dados os quais são geralmente observados nesse processo:

$\checkmark$ o tratamento dado ao leitor;

$\checkmark$ o gênero textual;

$\checkmark$ a quantidade de informações necessárias e relevantes;

$\checkmark$ a linguagem - formal ou informal - e o vocabulário;

$\checkmark$ a impessoalidade ou subjetividade;

$\checkmark$ as estruturas sintáticas e gramaticais;

$\checkmark$ ao objetivo previamente estipulado e a situação na qual está inserido.

Faraco e Tezza (2014) apresentam também como importante para um texto bem escrito a paragrafação e afirmam que na escrita o parágrafo é "antes de tudo (mas não apenas!) uma noção visual. A suspensão de uma sequência de linhas, com o recomeço destacado em outra linha, por si só cria significado. Por isso mesmo, não deve ser uma divisão aleatória" (FARACO \& TEZZA, 2014, p. 168). Os autores destacam características importantes desse elemento: não existe uma regra para sua utilização; seu uso depende da intenção e estratégia do autor; e sua organização depende da hierarquização das ideias e fatos expostos.

Olivieri (2010) oferece-nos algumas informações e técnicas sobre como escrever melhor e afirma: "escrever bem é um grande diferencial na vida pessoal e profissional do indivíduo" (OLIVIERI, 2010, p. 18). A autora, assim como Faraco e Tezza (2014), ratifica que não existe uma fórmula única que define uma boa escrita. Ainda assim, existem requisitos que influenciam na boa qualidade de um texto e estes precisam ser contemplados pelos estudantes.

Além da coesão e da coerência, já explicitados anteriormente, Olivieri (2010) destaca outros aspectos essenciais para a construção de um bom texto. A objetividade e a argumentação constituem tópicos também fundamentais nesse 
cenário. O primeiro diz respeito à "qualidade de tornar reais e objetivos, a ideia ou argumento daquilo que se concebeu" (OLIVIERI, 2010, p. 33) e precisa estar relacionada também com a clareza na exposição das ideias. Já o segundo aspecto corresponde à "qualidade de discutir, sugerir e implantar raciocínio [...] um bom raciocínio convence o leitor de suas ideias, de forma simples e clara. Não há rodeios e nem duplicidade de argumentos, ou seja, o famoso "disse, mas não disse"” (OLIVIERI, 2010, p. 34).

Ainda sobre a argumentação, Olivieri (2010) enfatiza a importância da releitura e revisão do trabalho como forma de reorganização dos argumentos utilizados na construção do texto, intencionando, mais uma vez, uma construção clara e objetiva, que facilite a compreensão do leitor, "afinal, um bom texto não é um aglomerado de frases, conceitos ou ideias. Retirar o excesso de um texto significa cortar tudo aquilo que nada significa ou está sobrecarregando o texto" (OLIVIERI, 2010, p .34).

Quando se escreve, é preciso focalizar também em outros quatro aspectos que Olivieri (2010) destaca. O primeiro deles é o público alvo, o leitor e sua relação com a intenção e com a finalidade do assunto. Para a autora, existem alguns aspectos que desagradam a maioria dos leitores, como: a falta de clareza, erros gramaticais, excesso de exemplos, repetição de palavras, frases muito longas, linguagem imprópria, uso de clichês e repetição exaustiva de argumentos. O segundo elemento é a qualidade, que para Olivieri (2010) está relacionado ao conteúdo do texto e a sua capacidade de agradar e convencer o leitor. Observe que esse segundo aspecto é bastante complexo e abrangente, podendo apresentar inúmeras variáveis, visto que a qualidade do texto também está relacionada à linguagem utilizada, ao contexto no qual está inserido, entre outros.

O terceiro aspecto mencionado por Olivieri (2010) é a originalidade, na capacidade de autoria do escritor, que não está apenas relacionado à habilidade de criar e apresentar dados novos, mas também está atrelado à competência da analise crítica de fatos, assuntos. Afirma a autora que "de nada adianta repetir clichês e frases feitas, isto desagrada ao leitor, porque fica evidente que o autor de texto não consegue se expressar de modo adequado e satisfatório" (OLIVIERI, 2010, p. 44). Relacionado 
a este, está o último aspecto que é o estilo do escritor, que é uma forma única de expressão. A originalidade junto ao estilo formam uma unidade que garante ao autor um espaço de autoria e reconhecimento em suas produções.

Alves (2014) nos fornece algumas orientações sobre como escrever melhor que vão ao encontro das considerações de Olivieri (2010), sendo algumas delas:

$\checkmark$ escrever é um recurso de progressão e manutenção temática, ou seja, quanto mais se escreve em determinada área, melhor se domina o assunto e melhor o texto é construído e defendido;

$\checkmark$ a gramática é uma norma, mas não é cerceadora;

$\checkmark$ períodos curtos são melhores no texto, visto que frases longas podem prejudicar a compreensão;

$\checkmark$ frases diretas exigem menos vírgulas;

$\checkmark$ palavras supérfluas empobrecem o texto;

$\checkmark$ o uso do dicionário é importante na construção de um texto e auxilia na ampliação de repertório de palavras; e

$\checkmark$ a repetição de palavras pode ser prejudicial, influenciando negativamente na compreensão de um texto.

Como é possível observar, não existe de fato um conjunto de regras, de normas, que ditam elementos únicos para se escrever bem. Porém, conforme os teóricos desta seção sugerem, é possível estabelecer alguns aspectos comuns que influenciam em uma boa escrita, sendo eles: a motivação inicial do escritor, a intencionalidade da escrita, a definição da linguagem que será utilizada, a clareza na exposição das ideias, a capacidade de argumentação, a necessidade de autoria, a coesão e a coerência. Todos esses aspectos, juntos, aliados ao exercício contínuo da escrita, tendem a qualificar uma escrita como boa. 


\section{A pesquisa}

Neste capítulo serão apresentados os objetivos do estudo, os meios utilizados para a concretização da pesquisa, desde o teste-piloto até a coleta de dados propriamente dita. Consideramos essencial a exposição deste cenário com vistas a clarificar a compreensão e estruturação da pesquisa

Este trabalho parte de um estudo anterior (ALMEIDA, 2013) que também estava preocupado com a formação dos professores e que demonstrou que os estudantes, após avaliarem a qualidade de sua escrita ortográfica, indicaram necessidade de apoio acadêmico através da implementação de uma disciplina obrigatória que trabalhasse com questões de escrita e, em segundo lugar, a criação de espaços específicos, com profissionais especializados, para darem maior suporte aos alunos que precisassem de ajuda.

Partindo dessas considerações, a partir de muitas discussões no Grupo de Pesquisa Desenvolvimento Humano e Educação (Grudhe), foi estabelecido um alvo e um objetivo: o primeiro são os estudantes e os professores do Curso de Pedagogia de uma universidade do Rio de Janeiro e o segundo é compreender como ocorre a relação dos discentes com a escrita e como eles são avaliados pelos docentes.

A partir desse esboço, procuramos definir os grupos de alunos com os quais poderíamos dialogar paralelamente com este estudo. Buscamos, então, por disciplinas que tivessem relação direta com a atividade de escrita como foco do trabalho. Foram encontradas na grade curricular duas disciplinas com tal atributo: uma obrigatória e outra optativa.

A fim de protegermos a identidade dos participantes, optamos por não divulgar os programas das disciplinas na íntegra. Porém, acreditamos ser oportuno apontar seus objetivos conforme especificados em suas ementas. A disciplina obrigatória tem como objetivo trabalhar aspectos do texto acadêmico. Já a disciplina optativa tem como objetivo explorar as múltiplas possibilidades da leitura e da escrita e engloba trabalhá-las a partir de diferentes gêneros textuais. Oferece objetivos amplos, que 
possibilitam ao professor maior flexibilidade em suas escolhas didáticas, podendo adaptá-las ao perfil específico de cada turma.

Participaram do estudo alunas que cursaram a disciplina obrigatória em um semestre (total de 12 alunas) e alunas que cursaram a disciplina optativa em dois semestres distintos (o primeiro grupo com 5 e o segundo grupo com 9 alunas). O total de participantes foi 26 alunas de Pedagogia.

Os professores que participaram da pesquisa foram os que lecionaram as três disciplinas escolhidas. Outros doze professores do curso de Pedagogia também participaram. Os docentes eram convidados pessoalmente a participarem da pesquisa. Porém, encontramos algumas dificuldades de entrar em contato com um maior número de professores e foi então preciso um contato prévio via email. Foram ao total quinze docentes participantes.

Não existiu neste estudo a pretensão de se acompanhar o processo de evolução da escrita em si, pois tal análise somente pode ser realizada por profissionais qualificados na área, como sugerem Geraldi (2011) e Damiani et al (2011). Este trabalho focou as visões e percepções do grupo quanto a um determinado aspecto de sua formação - a escrita. Ou seja, traduz-se em um estudo de caso sobre uma abordagem específica, uma análise profunda sobre um determinado objeto e suas ramificações, mediante o uso de variados instrumentos e técnicas para a coleta de dados.

\subsection{Objetivos e questões de pesquisa}

A partir da definição do objetivo maior da pesquisa, que é compreender a relação de estudantes de Pedagogia com a escrita, buscaremos também responder alguns questionamentos, como:

$\checkmark$ Como os alunos avaliam sua própria escrita?

$\checkmark$ Como os professores do Curso de Pedagogia avaliam a escrita de seus alunos? 
$\checkmark$ Como os professores do Curso de Pedagogia e os alunos avaliam o currículo?

$\checkmark$ O que leva estudantes de Pedagogia a se inscrevem em uma disciplina optativa específica para trabalhar leitura e escrita?

$\checkmark$ Os alunos percebem melhora nas suas produções? Como?

$\checkmark$ Os profissionais percebem progresso na escrita dos alunos? Como e em que aspectos?

$\checkmark$ Em quais "níveis" do modelo de processamento cognitivo da escrita de Flower e Hayes (1980) é possível perceber onde estão localizadas as dificuldades dos alunos e o trabalho do professor?

Essas questões são fundamentais para nossos objetivos específicos da pesquisa, a saber:

$\checkmark$ Descrever o trabalho de disciplinas específicas realizadas na universidade para intervenção na prática escrita dos estudantes;

$\checkmark$ Identificar a atual relação dos estudantes com a escrita, destacando suas práticas;

$\checkmark$ Compreender como e por que acontece a procura por apoio para melhoria da produção escrita por uma disciplina optativa específica.

$\checkmark \quad$ Identificar como e se os alunos e os professores percebem o progresso dos primeiros e quais as práticas intervencionistas que são utilizadas em sala;

$\checkmark$ Descrever o posicionamento dos professores do Curso quanto às medidas que são utilizadas para ajudar alunos que precisam de apoio e quanto à sua eficácia;

$\checkmark$ Situar as dificuldades dos alunos no modelo processual da escritura de Flower e Hayes (1980)?

$\checkmark$ Contribuir para o campo da pesquisa em Educação buscando demonstrar quais trabalhos tendem a acarretar na melhoria da produção escrita de futuros professores. 


\subsection{Técnicas de pesquisa}

Para adentrar significativamente nesse universo, decidimos que o melhor caminho a ser percorrido seria o qualitativo, pois entendemos que as análises poderiam ser melhor esmiuçadas, compreendidas e interpretadas de maneira mais significativa. Optamos por um estudo de caso, com as técnicas do questionário e da entrevista, que aparentam ser suficientes para possibilitar os apontamentos e posicionamentos de variados grupos.

Configuramos correspondentemente as técnicas de pesquisa com os sujeitos conforme exposto abaixo:

\section{Quadro 1. Participantes da pesquisa}

\begin{tabular}{|c|c|}
\hline Participante & Coleta \\
\hline Alunos das três disciplinas & $\begin{array}{c}\text { Questionário e } \\
\text { Entrevista }\end{array}$ \\
\hline Professores do Curso & Entrevista \\
\hline $\begin{array}{c}\text { Professores das disciplinas } \\
\text { específicas }\end{array}$ & Entrevista \\
\hline
\end{tabular}

Para os estudantes, no início de semestre, foi elaborado um questionário para preenchimento de dados gerais e específicos. O instrumento (ver Apêndice III) continha questionamentos sobre:

$\checkmark$ trajetória escolar;

$\checkmark$ práticas atuais de escrita;

$\checkmark$ influência da família no desempenho;

$\checkmark$ motivo para estarem inscritos na disciplina optativa;

$\checkmark$ autoavaliação sobre desempenhos atuais; etc.

Para o final do semestre, foi criada uma entrevista (ver Apêndice IV) para ser realizada com os estudantes que desejassem participar, com o intuito de perceber como eles avaliariam a disciplina que cursaram e como percebem seu progresso (ou não). 
Para os professores das disciplinas selecionadas para a pesquisa, foi elaborada uma entrevista (ver Apêndice V) a ser realizada ao final do semestre letivo, visando compreender:

$\checkmark$ quais foram as práticas utilizadas em sala de aula,

$\checkmark$ se eles perceberam ou não o progresso dos alunos,

$\checkmark$ quais eram as maiores dificuldades encontradas,

$\checkmark$ como eles comparam os estudantes de pedagogia com os de outros cursos (caso já tenham lecionado para alunos de outras áreas), e

$\checkmark$ identificar como os professores trabalham, seus principais objetivos, metodologias de trabalhos, entre outras questões.

Também foi produzida uma entrevista semelhante para os professores do curso de Pedagogia em geral (ver Apêndice VI) para compreender o quanto os mesmos indicam ou não preocupação com a qualidade da escrita dos futuros docentes e seus porquês, capacidade para identificar e corrigir erros, sobre a qualidade da escrita dos alunos em geral e outras questões que sejam relevantes.

Todos os questionários foram analisados com o auxílio do programa Excel e todas as entrevistas foram analisadas com ajuda do software Atlas $\mathrm{Ti}^{13}$, que consiste em uma ferramenta para a análise qualitativa de dados. O software aceita diferentes formatos de mídias e documentos, e é capaz de promover o cruzamento de arquivos, possibilitando a produção de diferentes tipos de relatórios a partir dos critérios do usuário.

No programa, lançamos todas as entrevistas realizadas com os alunos e professores. Criamos ao total três grupos de famílias, conforme o quadro 1 demonstra. A partir daí, codificamos trechos e expressões que identificamos como relacionados à respostas dos questionamentos da pesquisa. Observe-se, por exemplo, o depoimento do Professor 8 sobre a realização de correções: "Então a partir desses

\footnotetext{
${ }^{13}$ No Apêndice VII é possível conferir a lista de códigos, suas descrições e exemplos criados para a análise dos dados.
} 
conceitos, desses papéis que eles apresentam, eu faço uma correção do conteúdo, se o conceito está bem e explicitado, bem formulado digamos, depois uma avaliação ortográfica, da correção da formulação em português e da coesão do texto, ou seja, se tem começo, meio e fim". Ao analisarmos essa frase, conseguimos construir três códigos para esse trabalho: correção de aspectos conceituais, correção de aspectos gramaticais e correção de conteúdo e forma. Realizamos essa ação com todas as entrevistas e a partir daí, conseguimos cruzar alguns dados, perceber a maior incidência de ocorrência de uma determinada prática, por exemplo, entre outras formas de utilização.

\subsection{Piloto}

Todos os instrumentos a serem utilizados na empiria foram criados a partir de Leta (2005), Santos (2006) e Almeida (2013). Foram construídos pela autora deste trabalho e compartilhados no Grudhe, que forneceu considerações substanciais para a elaboração plena dos materiais.

As perguntas foram previamente testadas no próprio grupo de pesquisa, que tem como integrantes estudantes de graduação de Pedagogia e professores de diversas áreas. As correções e ajustes que foram sugeridos foram aceitos plenamente, não ocorrendo maiores divergências quanto aos objetivos previamente estipulados. As questões problemáticas que surgiram foram duas: uma primeira quanto à adequação da linguagem para com o instrumento a ser utilizado com os estudantes e a segunda em relação à discussão sobre o conceito de erro, termo que constava nas entrevistas dos professores e que poderia gerar confusão ou ser interpretado como preconceituoso.

\subsection{Recrutamento}


Como já foi dito, a pesquisa trabalha com estudantes e professores.

Nas disciplinas optativas, os professores foram previamente informados sobre o conteúdo da pesquisa através de uma conversa formal entre as partes e concordaram em participar do estudo e também permitiram um primeiro contato da pesquisadora com os alunos para explicar a pesquisa.

Após esse processo, os dias para administração do questionário com os estudantes foram previamente combinados com a professora, que informava aos alunos sobre a data da realização da pesquisa. Para obter o maior número de participantes, esses momentos de encontro com as estudantes foram constantes, pois foi preciso considerar a assiduidade da turma.

$\mathrm{Na}$ disciplina obrigatória, foi necessário apenas um dia para aplicação do questionário. Em uma disciplina optativa, foram necessários seis dias de visitas para conseguir aplicar os questionários para o grupo todo. $\mathrm{Na}$ outra, foi fundamental a participação de integrantes de Grudhe, que auxiliaram na aplicação dos questionários. Nos primeiros encontros em cada turma, os grupos foram informados sobre o desenvolvimento da pesquisa e seus objetivos. Todas as dúvidas foram sanadas e esclareceu-se que a participação era voluntária. Todos os participantes que estavam presentes consentiram com a pesquisa e com seus termos, firmando a aceitação no Termo de Consentimento Livre e Esclarecido que consta no Apêndice II.

As entrevistas com os estudantes ocorreram em um único dia, ao final do semestre. As entrevistas foram efetuadas nos momentos de aula oferecidos pelos docentes com duração média de trinta minutos. Foi necessário o uso de um gravador de voz e a professora se ausentou para deixar a turma mais à vontade.

Este procedimento funcionou para a disciplina obrigatória e para uma optativa. A outra turma, que já tinha cursado a optativa no semestre anterior, não pôde ser entrevistada em sala de aula. Os alunos foram contatados via tecnologia Whatsapp $^{14}$.

\footnotetext{
${ }^{14}$ Whatsapp é um recurso da telefonia móvel de uso comum e popular no mundo, que possibilitou agrupar todos os estudantes em um único espaço virtual.
} 
Conseguimos estabelecer um dia para executarmos a entrevista e obtivemos a participação de três alunas.

Com os professores das disciplinas específicas, como já haviam sido informados sobre o estudo, foram contatados via e-mail para a realização da entrevista no final do período letivo, após poderem ser capazes de oferecer um panorama completo sobre a turma com a qual trabalharam. Os professores escolheram o local onde gostariam de realizar a entrevista, com exceção do professor de uma das optativas, que estava com dificuldades na compatibilização de horários e respondeu a entrevista por e-mail. Já com os professores do Curso em geral, o início foi um pouco difícil. Eles foram abordados em suas salas, mas apresentavam alguma resistência a participar quando o assunto era mencionado. Inicialmente, apenas quatro professores aceitaram participar da entrevista e realizaram-na no mesmo momento. Diante desse panorama, um e-mail foi enviado para todos os professores do Curso, por intermédio da orientadora deste trabalho. A partir daí, conseguimos aumentar a quantidade de participantes, totalizando 12 professores participantes. Toda a interlocução com eles aconteceu via e-mail, com local e horário escolhidos pelos próprios, conforme suas disponibilidades. Todos os quinze docentes assentiram com a pesquisa e seus termos através do Termo de Consentimento Livre e Esclarecido (ver Apêndice I)

\subsection{Perfil dos participantes}

Após a aplicação das técnicas de pesquisa com os participantes deste estudo, foi possível traçar um breve perfil a respeito dos grupos. Os estudantes que participaram do questionário foram 26 e da entrevista foram 17. Também obtivemos participação dos professores do Curso, tanto das disciplinas específicas (3), quanto das disciplinas gerais (12). Foram ao todo 15 professores participantes.

$O$ código utilizado para identificar cada professor conjuga uma letra $-P$ - e um número por ordem crescente, designados de forma aleatória. Com os professores das 
disciplinas específicas não foi diferente, porém, por uma questão de clareza, decidimos utilizar o formato $P E+$ número para nomeá-los. Os professores de P1 a P12 são os professores das disciplinas gerais do Curso. Já os docentes PE13, PE14 e PE15 são os professores das disciplinas específicas.

Dos professores participantes, seis são formados em Pedagogia, dois em Letras. Doze professores possuem Mestrado na área de Educação e doze possuem Doutorado na mesma área. O quadro abaixo discrimina a formação deles:

Quadro 2. Formação dos professores do Curso de Pedagogia da instituição estudada

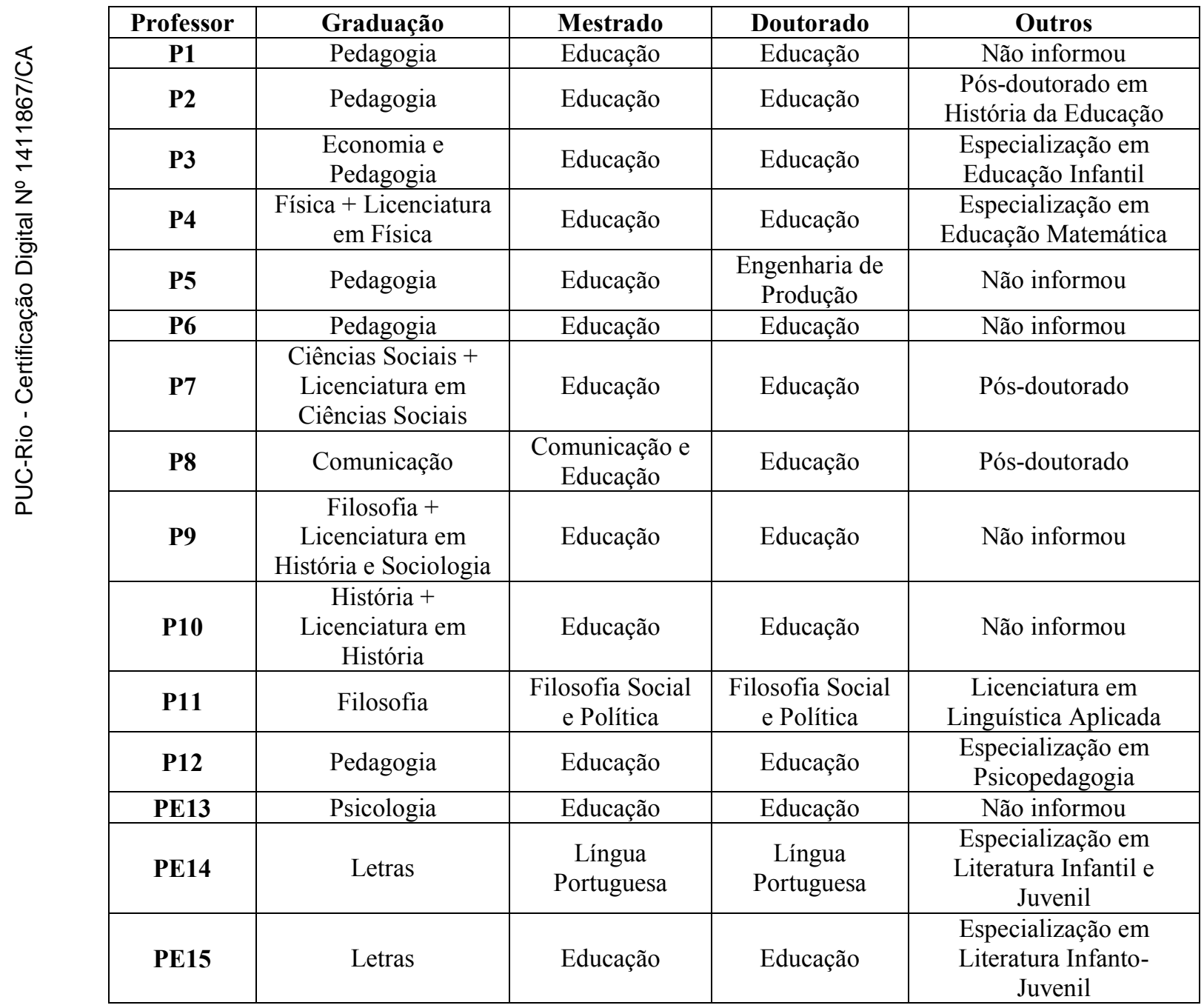


O outro grupo de participantes é composto por 26 alunas.. São os estudantes de Graduação de Pedagogia, cursando diferentes períodos. Como todas as participantes são do sexo feminino, as desinências de todos os substantivos e adjetivos serão no mesmo gênero. Inicialmente, utilizamos o código ESTUDANTE + número para podermos identificá-las.

Um total de 26 estudantes participaram desta pesquisa, sendo 12 alunas da disciplina obrigatória e 14 da disciplina optativa e todas responderam ao questionário. Dessas, apenas 17 participaram da entrevista.

Para melhor identificação dos grupos de participantes, realizamos uma divisão:

Quadro 3. Distribuição das alunas por grupos de disciplinas

\begin{tabular}{|c|c|c|}
\hline \multicolumn{3}{|c|}{$1^{\circ}$ Grupo: Disciplina obrigatória } \\
\hline Participante & Período & Entrevista \\
\hline Estudante 1 & 1 & $\mathrm{X}$ \\
\hline Estudante 2 & - & $\mathrm{X}$ \\
\hline Estudante 3 & 1 & $\mathrm{X}$ \\
\hline Estudante 4 & 1 & $\mathrm{X}$ \\
\hline Estudante 5 & - & $\mathrm{X}$ \\
\hline Estudante 6 & 1 & $\mathrm{X}$ \\
\hline Estudante 7 & 1 & $\mathrm{X}$ \\
\hline Estudante 8 & 1 & $\mathrm{X}$ \\
\hline Estudante 9 & 1 & $\mathrm{X}$ \\
\hline Estudante 10 & 1 & $\mathrm{X}$ \\
\hline Estudante 11 & 1 & Não participou \\
\hline Estudante 12 & 1 & $\mathrm{X}$ \\
\hline Total $=12$ & & \\
\hline \multicolumn{3}{|c|}{$2^{\circ}$ Grupo: disciplina optativa - 1} \\
\hline Participante & Período & Entrevista \\
\hline Estudante 13 & 9 & $\mathrm{X}$ \\
\hline Estudante 14 & 8 & $\mathrm{X}$ \\
\hline Estudante 15 & 8 & Não participou \\
\hline Estudante 16 & 7 & Não participou \\
\hline Estudante 17 & 6 & $\mathrm{X}$ \\
\hline Total $=5$ & & \\
\hline \multicolumn{3}{|c|}{$3^{\circ}$ Grupo: disciplina optativa - 2} \\
\hline Participante & Período & Entrevista \\
\hline Estudante 18 & 5 & Não participou \\
\hline Estudante 19 & 5 & Não participou \\
\hline Estudante 20 & 5 & $\mathrm{X}$ \\
\hline Estudante 21 & 5 & Não participou \\
\hline Estudante 22 & 4 & $\mathrm{X}$ \\
\hline Estudante 23 & 4 & $\mathrm{X}$ \\
\hline Estudante 24 & 5 & Não participou \\
\hline
\end{tabular}




\begin{tabular}{|c|c|c|}
\hline Estudante 25 & 6 & Não participou \\
\hline Estudante 26 & 6 & Não participou \\
\hline Total $=9$ & & \\
\hline
\end{tabular}

(conclusão)

As Estudantes 2 e 5 foram as únicas que não informaram o período que estavam cursando naquele momento. Nenhuma das estudantes cursou ou cursa outra Graduação, além da Pedagogia. Infelizmente, cometemos uma falha ao não questionarmos o grupo sobre a escolha do curso de Pedagogia como sendo primeira opção ou não e, em caso negativo, qual outra opção o aluno tinha em mente. As participantes são estudantes que estão tanto em períodos iniciais, quanto em períodos finais, permitindo-nos um panorama razoável da opinião do corpo discente, já que elas representam aproximadamente $27 \%$ do corpo discente total.

A maioria delas possui formação apenas em escolas públicas:

Tabela 1. Espaço de formação da escolarização básica das alunas

\begin{tabular}{lcccc}
\hline Tipo de escola & E.F. & E.M. & E.F. $\%$ & E.M.\% \\
\hline Pública & 14 & 17 & 53,8 & $\mathbf{6 5 , 4}$ \\
Privada & 8 & 7 & 30,8 & 27 \\
Misto & 2 & 1 & 7,7 & 3,8 \\
Não Responderam & 2 & 1 & 7,7 & 3,8 \\
$\quad$ Total: & $\mathbf{2 6}$ & $\mathbf{2 6}$ & $\mathbf{1 0 0}$ & $\mathbf{1 0 0}$ \\
\hline
\end{tabular}

A partir do quadro a seguir, é possível perceber que 12 alunas possuem formação no Ensino Fundamental e no Ensino Médio exclusivamente em escolas públicas e 6 exclusivamente em escolas privadas. Todas as outras estudantes serão enquadradas neste trabalho na categoria "formação mista", que foi criada com o intuito de abranger as alunas que estudaram parte da Educação Básica em escolas privadas e outra parte em escolas públicas.

Quadro 4. Distribuição das respostas da escolarização básica por aluno e por etapa

\begin{tabular}{|c|c|c|c|}
\hline \multirow{2}{*}{ Participante } & \multicolumn{2}{|c|}{ Respostas } & Classificação \\
\cline { 2 - 4 } & Ens. Fundamental & Ens. Médio & Formação \\
\hline Estudante 1 & privada & pública & Mista (M) \\
\hline
\end{tabular}




\begin{tabular}{|c|c|c|c|}
\hline Estudante 2 & pública & pública & Pública (PB) \\
\hline Estudante 3 & privada & privada & Privada (PR) \\
\hline Estudante 4 & privada & privada & Privada (PR) \\
\hline Estudante 5 & pública & misto & Mista (M) \\
\hline Estudante 6 & privada & privada & Privada (PR) \\
\hline Estudante 7 & pública & pública & Pública (PB) \\
\hline Estudante 8 & privada & privada & Privada (PR) \\
\hline Estudante 9 & misto & pública & Mista (M) \\
\hline Estudante 10 & pública & pública & Pública (PB) \\
\hline Estudante 11 & misto & pública & Mista (M) \\
\hline Estudante 12 & privada & privada & Privada (PR) \\
\hline Estudante 13 & pública & pública & Pública (PB) \\
\hline Estudante 14 & pública & pública & Pública (PB) \\
\hline Estudante 15 & pública & pública & Pública (PB) \\
\hline Estudante 16 & pública & pública & Pública (PB) \\
\hline Estudante 17 & pública & pública & Pública (PB) \\
\hline Estudante 18 & privada & pública & Mista (M) \\
\hline Estudante 19 & pública & pública & Pública (PB) \\
\hline Estudante 20 & não respondeu & não respondeu & não respondeu \\
\hline Estudante 21 & privada & privada & Privada (PR) \\
\hline Estudante 22 & pública & pública & Pública (PB) \\
\hline Estudante 23 & pública & pública & Pública (PB) \\
\hline Estudante 24* & não respondeu & pública & Mista (M) \\
\hline Estudante 25 & pública & pública & Pública (PB) \\
\hline Estudante 26 & pública & privada & Mista (M) \\
\hline
\end{tabular}

*Nota: Como a Estudante 24 não indicou sua formação no Ensino Fundamental, optamos por enquadrá-la na categoria "mista".

A partir do perfil traçado na seção anterior sobre as estudantes, foi possível estabelecer essa categorização em três grandes blocos de alunas conforme sua escolarização anterior. As alunas foram classificadas de três formas: as que tinham formação tanto em escola pública como privada, foram classificadas em "mista" (M); as que tinham formação exclusivamente em escolas públicas, receberam o rótulo "pública" (PB); e alunas com formação exclusivamente em escolas privadas, foram classificadas como "privada" (PR). A partir de agora, faremos referência às alunas por seu número e formação, usando as siglas apresentadas.

Ao criarmos essa categorização das estudantes baseada em sua formação, intencionamos perceber as relações que podem ser estabelecidas entre seu desempenho e sua escolarização anterior. Certamente temos também a consciência de que, atualmente, é complicado polarizar a educação pública da educação privada, 
devido às similaridades e discrepâncias que podem existir entre os diferentes sistemas de ensino. Para que essa comparação pudesse construída, seria necessário criar um instrumento de pesquisa mais elaborado, que indicasse o espaço próprio da escolarização do participante, um perfil sócio-econômico, entre outros aspectos. Entretanto, conforme será demonstrado em seções posteriores, foi perceptível marcas nos depoimentos dos professores sobre essa diferenciação, além de também termos conseguido perceber esse tipo de indícios nas avaliações dos alunos, por exemplo quanto à avaliação da grade curricular do curso. Então, a partir da constatação desse dado, decidimos classificar as alunas participantes também quanto à sua formação, permitindo também ao leitor desta pesquisa realizar suas inferências sobre o assunto $^{15}$.

\footnotetext{
15 Observemos que $46 \%$ das participantes que consideram esse currículo insuficiente possuem formação exclusivamente em escolas públicas. Mas, é interessante destacar que, apesar de termos construído uma categorização das alunas baseada em sua formação, não estamos com isso assumindo que toda escola pública é de qualidade inferior a qualquer escola privada. Não obstante, como vemos nos discursos de nossos participantes essa noção presente, julgamos relevante levá-la em conta em nossas análises.
} 


\section{Análise de dados e problematizações}

A partir desse capítulo, vamos apresentar os resultados da pesquisa e elaborar algumas correlações com os referenciais teóricos sobre o assunto, alguns já apresentados anteriormente e outros que surgiram concomitantemente com a análise dos resultados. Optamos por criar sete seções dentro desta para abranger a grande quantidade de dados.

\subsection{Considerações iniciais entre as estudantes}

Do total de respondentes (26), 12 alunas estudaram apenas em escola pública, o que equivale a $46 \%$ do total. Quando essas alunas foram indagadas sobre o domínio que possuem da norma padrão, nenhuma delas se declarou com domínio pleno ou precário. As estudantes 2PB, 10PB, 13PB, 14PB, 16PB, 19PB, 22PB, 23PB e 25PB classificaram esse domínio como estando "dentro da média". As estudantes 7PB e 17PB foram as únicas que apontaram domínio "abaixo da média" e "com dúvidas sistemáticas". Por fim, a estudante 15PB é a única que classifica seu domínio como "acima da média", com "dúvidas pontuais".

Tabela 2. Domínio da norma padrão de estudantes de formação exclusivamente em escola pública

\begin{tabular}{|c|c|c|}
\hline Opções de Resposta & Frequência & $\%$ \\
\hline Dentro da média. & 9 & $75 \%$ \\
\hline Abaixo da média, pois tenho dúvidas sistemáticas. & 2 & $16,7 \%$ \\
\hline Acima da média, mas tenho dúvidas pontuais. & 1 & 8,3 \\
\hline Domínio pleno. & 0 & 0 \\
\hline Domínio precário. & 0 & 0 \\
\hline & 12 & 100 \\
\hline
\end{tabular}

Para as estudantes $2 \mathrm{~PB}$ e $13 \mathrm{~PB}$, a escola foi o principal fator para o domínio que apontam ter (dentro da média). No outro extremo, para as estudantes 7PB e 
25PB, a escola contribuiu pouco (abaixo da média e dentro da média, respectivamente). Para $66,6 \%$ das estudantes a escola contribuiu, mas não foi o principal fator (Estudantes: 10PB, 14PB, 15PB, 16PB, 17PB, 19PB, 22PB e 23PB). Vejamos:

Tabela 3. Contribuição da escola para as estudantes de formação exclusivamente em escolas públicas

\begin{tabular}{|c|c|c|}
\hline Opções de Resposta & Frequência & $\%$ \\
\hline A escola contribuiu, mas não foi o principal fator & 8 & $66,6 \%$ \\
\hline A escola foi o principal fator. & 2 & $16,7 \%$ \\
\hline A escola contribuiu pouco & 2 & $16,7 \%$ \\
\hline A escola não contribuiu & 0 & 0 \\
\hline
\end{tabular}

Com a oportunidade de poder indicar quais outros fatores ${ }^{16}$ contribuíram para o domínio que acreditam ter, para as estudantes 13PB, 14PB, 17PB e 23PB a família é considerada o outro principal fator. A leitura, porém, foi o item mais selecionado pela maioria (Estudantes: 2PB, 7PB, 10PB, 15PB, 16PB, 19PB, 22PB e 25PB). Apenas duas alunas - 14PB e 15PB - selecionaram a opção “outros ambientes culturais". É interessante observar que a estudante 14PB marcou "ambiente familiar" e "outras atividades culturais" igualmente como primeira opção, assim como a estudante 15PB o fez com "leitura" e "outros ambientes culturais". Somente uma aluna (Estudante 2PB) descreveu uma quarta opção, que era de escrita livre e opcional: "Interesse próprio".

Já em relação às estudantes de formação exclusivamente em escola privada, que são 6, a maioria considera que apresenta domínio da norma padrão acima da média, com dúvidas pontuais (Estudantes 3PR, 4PR, 8PR e 12PR). Duas estudantes (6PR e 21PR) já sugerem um domínio dentro da média. Os principais fatores que contribuíram para o domínio que "dizem" possuir foram: para a estudante 6PR, a escola foi o principal fator; para as estudantes 3PR, 4PR, 8PR e 12PR, a escola

\footnotetext{
${ }^{16}$ Ver Apêndice III.
} 
contribuiu mas não foi o principal fator; e para a estudante $21 \mathrm{PR}$, a escola contribuiu pouco.

Tabela 4. Contribuição da escola para as estudantes de formação exclusivamente em escola privada

\begin{tabular}{|c|c|c|c|}
\hline Opções de Resposta & & Frequência & $\%$ \\
\hline A escola contribuiu, mas não foi o principal fator & & 4 & $66,6 \%$ \\
\hline A escola contribuiu pouco & & 1 & $16,7 \%$ \\
\hline A escola foi o principal fator & & 1 & $16,7 \%$ \\
\hline A escola não contribuiu & & 0 & 0 \\
\hline & Total: & 6 & 100 \\
\hline
\end{tabular}

Para 3 participantes (Estudantes 3PR, 4PR e 12PR) a família, além da escola, contribuiu em primeiro lugar. Já para 2 participantes (Estudantes 6PR e 8PR), a leitura foi também o mais importante. A estudante 21PR, porém, atribuiu total importância à Faculdade e a nenhum dos outros itens.

Já as alunas que se enquadram na categoria "formação mista" são as Estudantes 1M, 5M, 9M, 11M, 18M, 24M e 26M. A Estudante 5M se considera com domínio acima da média, com dúvidas pontuais. A Estudante $9 \mathrm{M}$ se considera com domínio abaixo da média, com dúvidas sistemáticas. As outras cinco estudantes afirmam ter domínio dentro da média.

Quadro 5. Domínio da norma padrão por alunas da categoria "formação mista"

\begin{tabular}{|c|c|c|}
\hline Participante & $\begin{array}{c}\text { Domínio da norma } \\
\text { padrão }\end{array}$ & Importância da escola \\
\hline Estudante 5M & Acima da média & Contribuiu, mas não foi o principal \\
\hline Estudante 1M & Dentro da média & Contribuiu, mas não foi o principal \\
\hline Estudante 11M & Dentro da média & Contribuiu, mas não foi o principal \\
\hline Estudante 18M & Dentro da média & Contribuiu pouco \\
\hline Estudante 24PB & Dentro da média & Principal fator \\
\hline Estudante 26M & Dentro da média & Contribuiu, mas não foi o principal \\
\hline Estudante 9M & Abaixo da média & Contribuiu pouco \\
\hline
\end{tabular}

Para a maioria das participantes, o outro fator que mais contribuiu para o domínio que dizem possuir, além da contribuição escolar, foi a leitura. Apenas para a Estudante $18 \mathrm{M}$ foi a família. 
Quadro 6. Contribuição além da escola para alunas da categoria "formação mista"

\begin{tabular}{|c|c|c|c|c|}
\hline Participante & $\mathbf{1}^{\mathbf{0}}$ lugar & $\mathbf{2}^{\mathbf{0}}$ lugar & $\mathbf{3}^{\mathbf{0}}$ lugar & Outros \\
\hline Estudante 1M & Leitura & $\begin{array}{c}\text { Outros ambientes } \\
\text { culturais }\end{array}$ & Família & \\
\hline Estudante 5M & Leitura & - & - & \\
\hline Estudante 9M & Leitura & $\begin{array}{c}\text { Outros ambientes } \\
\text { culturais }\end{array}$ & Família & \\
\hline Estudante 11M & Família & Leitura & $\begin{array}{c}\text { Outros ambientes } \\
\text { culturais }\end{array}$ & $\mathbf{2}$ \\
\hline Estudante 18M & Leitura & $\mathbf{4}$ (família) & $\begin{array}{c}\text { Outros } \\
\text { ambientes } \\
\text { culturais }\end{array}$ & \\
\hline Estudante 24PB & Leitura & $\begin{array}{c}\text { Outros ambientes } \\
\text { culturais }\end{array}$ & Família & \\
\hline Estudante 26M & Leitura & Família & $\begin{array}{c}\text { Outros ambientes } \\
\text { culturais }\end{array}$ & \\
\hline
\end{tabular}

A Estudante 20 não respondeu à questão sobre a sua escolarização, mas informou que tem domínio da norma padrão dentro da média, tendo sido a escola o principal fator para o domínio que ela afirma possuir. Além da escola, para ela a família contribuiu em primeiro lugar para seu domínio, seguida da leitura e de outros ambientes culturais.

\subsubsection{Visão dos professores a respeito das estudantes}

E como será que os professores do curso qualificam os alunos do curso de Pedagogia? Através de algumas passagens, foi possível também montar um perfil do alunado de acordo com as visões dos docentes.

Foram obtidas respostas de seis professores sobre essa categoria. Para P10 e P4, nos períodos iniciais da Faculdade, os alunos chegam com muitas dificuldades, que vão sendo "sanadas" ao longo do curso. O P4 ainda prossegue, sustentando a precariedade da escola pública e da formação dos alunos: “Eu acho que é uma coisa que vem da educação básica de quem procura essas áreas, as licenciaturas e inclusive Pedagogia, muita gente vem de escolas, mais da metade vem das escolas 
públicas, de uma escolarização da escola pública, infelizmente em uma escola pública quase sempre de péssima qualidade aonde não foi desenvolvida a linguagem da maneira como acho que deveria ter sido, mas como também não foram desenvolvidas várias outras coisas, conteúdos de História, de Geografia, de Matemática”.

Curiosamente, P2 realiza uma correlação entre a carreira docente e o grupo de pessoas que procuram por ela: "cada vez mais o pessoal que procura a carreira docente é o pessoal que vem das camadas mais populares, que vem da escola pública, que, portanto traz uma série de deficiências na sua formação básica. Então eu acho que o problema não é do curso, o problema é de quem está procurando esse curso". P5 corrobora tal perspectiva, ao dizer que: "Os alunos do curso de Pedagogia em geral, de uma maneira muito genérica, são alunos que são oriundos de classes mais pobres da população, em geral eles vêm de escolas públicas, mais fracas, eles vêm de longe, então são de outros municípios muitas vezes, não são aqui do município do Rio de Janeiro. E você percebe que a base da escrita deles é uma base fraca".

P12 e PE13, por sua vez, mencionam a questão de tempo de aula e sua relação com o cotidiano cansativo do grupo. Ambos os professores relatam suas tentativas de adequar o curso à rotina dos estudantes. Enquanto P12 menciona a relação entre a necessária maleabilidade das atividades e as exigências acadêmicas, PE13 conta como também podem ocorrer frustrações nas tentativas de adequação entre a vida universitária e a pessoal. Diz P12: "Eu tento fazer alguns combinados com elas, administrar um pouco isso, compreendendo por um lado as dificuldades que elas têm, mas ao mesmo tempo exigindo delas, porque elas estão matriculadas em um curso que começa às sete horas. Então, alguma maneira, para dar conta disso elas precisam conseguir, mas não é uma coisa simples". PE13, ao tratar sobre o uso de tecnologias, afirma: "O Moodle é bacana, a plataforma é bacana, mas pra quem faz estágio... Elas trabalham, todas as minhas alunas trabalham e fazem estágio. Então trabalhar, assistir aula e fazer estágio, e ainda chegar em casa e conversar no Moodle, mandar o trabalho, comentar o trabalho dos outros, então para mandar o 
trabalho delas elas mandaram, mas o que eu queria que elas comentassem o trabalho umas das outras não funcionou".

\subsection{Concepções de escrita dos docentes}

Todos os professores consideram a escrita muito importante para um curso de formação de professores. Suas reflexões focam a relação da escrita com a leitura, a escrita na sociedade, a escrita presente em todas as atividades do cotidiano, o uso da escrita formal e o uso como instrumento de trabalho do professor. Porém, a escrita na sociedade e a importância do domínio do professor foram os fatores mais citados. $\mathrm{O}$ quadro abaixo resume as elaborações dos docentes.

Quadro 7. A importância da escrita para os professores

\begin{tabular}{|c|c|}
\hline Docente & Depoimento \\
\hline P1 & $\begin{array}{l}\text { A escrita é importante na sociedade, mas para um professor é imprescindivel; } O \\
\text { professor vai ter que, não só escrever, escrever para os alunos, escrever para os pais, } \\
\text { escrever planos de aula, como ele também vai ter que ensinar os meninos a escrever, } \\
\text { e eu acho que a gente náo consegue ensinar o outro a escrever se a gente não tem o } \\
\text { domínio da escrita, domínio próprio como professor e como pessoa. }\end{array}$ \\
\hline P2 & $\begin{array}{l}\dot{E} \text { fundamental, até porque eles vão ser professores, eles vão ensinar as crianças a } \\
\text { escrever, então é central. E eu acho que sem um domínio da leitura e da escrita fica } \\
\text { complicado qualquer outro tipo de aprendizagem, isso é base, fundamental. }\end{array}$ \\
\hline P3 & $\begin{array}{l}\text { Eu não vejo como não ter a escrita, eu acho que faz parte. Não vejo como não ter } \\
\text { assim, na nossa sociedade na forma como ela está estruturada e o papel da escrita. }\end{array}$ \\
\hline P4 & Com certeza, você não pode ser professor sem escrever direito. \\
\hline P5 & $\begin{array}{l}\text { Eu acho muito importante aprender a comunicar-se em uma linguagem formal, e eles } \\
\text { estão em uma universidade, eles participam do mundo acadêmico, eles têm que saber } \\
\text { escrever um português correto. }\end{array}$ \\
\hline P6 & $\begin{array}{l}\text { Eu acho que ela é importantíssima, agora será que a leitura é importante no curso de } \\
\text { formação de professores, porque eu acho que a leitura e a escrita elas caminham } \\
\text { juntas, então eu acho importante pensar assim: 'você, professora, é uma leitora?', se } \\
\text { você não for uma leitora, será que você vai conseguir passar o amor pela leitura, a } \\
\text { importância da leitura, então eu acho que isso talvez o curso pudesse fazer mais. }\end{array}$ \\
\hline P7 & Muito importante. \\
\hline P8 & Absolutamente sim. \\
\hline P9 & $\begin{array}{l}\text { Olha, eu acho que sim, é fundamental, eu acho que a escrita é fundamental na nossa } \\
\text { sociedade. Mas na formação de professores eu acho importante eles estarem bem, } \\
\text { essa palavra eu não sei se é muito boa, bem equipados digamos assim, com várias } \\
\text { possibilidades de registro, resumo, tópicos, quadro, pequenas dissertações, redação, } \\
\text { para que eles escrevam bem como professores e para que eles ensinem a escrever } \\
\text { bem aos seus alunos. Elas vão basicamente ser professoras, estou falando elas }\end{array}$ \\
\hline
\end{tabular}




\begin{tabular}{|c|c|}
\hline & $\begin{array}{l}\text { porque a maioria no curso de Pedagogia são mulheres, vão trabalhar, muitas com } \\
\text { Educação Infantil, mas a maioria com primeiro ao quinto ano, então a escrita é } \\
\text { fundamental. }\end{array}$ \\
\hline P10 & Sim. \\
\hline P11 & $\begin{array}{l}\text { Considero isso muito importante para a formação de qualquer pessoa, qualquer } \\
\text { área, mas especificamente o professor, porque como essa pessoa vai ajudar outros a } \\
\text { fazerem isso se eles não conseguem fazer? }\end{array}$ \\
\hline P12 & $\begin{array}{l}\text { Eu diria para você que é essencial porque essas professoras vão ensinar, incentivar } \\
\text { os alunos à escrita no futuro, e aí eu volto àquilo que eu te disse antes, eu não ensino } \\
\text { aquilo que eu não sei. }\end{array}$ \\
\hline PE13 & A escrita é o nosso meio de comunicação com a sociedade. \\
\hline PE14 & Não respondeu. \\
\hline PE15 & $\begin{array}{l}\text { A escrita é um dos múltiplos modos de comunicação. Através dela estabelece-se } \\
\text { relação de diálogo e de autoria. A escrita é importante em todos os momentos em que } \\
\text { outras formas de comunicação não se fazem viáveis, quando ela é a única forma de } \\
\text { comunicação ou expressão. }\end{array}$ \\
\hline
\end{tabular}

(conclusão)

Sempre que o assunto é a escrita, muitas discussões surgem em torno da concepção de que cada pessoa dispõe. Debater sobre questões que envolvem a escrita de estudantes, sejam eles universitários ou não, é um tópico bastante polêmico no meio acadêmico.

A partir dessas considerações, perguntamos: Quais são as concepções de escrita dos professores do Curso de Pedagogia? As entrevistas revelaram que as concepções são variadas, mas que, de certo modo, se interligam. São visões que revelam, de modo geral, a noção da complexidade do ato de escrever, a percepção da escrita como forma de poder, como forma de prazer, como organização do pensamento e modo de comunicação.

P1 revela a dificuldade que acredita existir na escrita: "Eu acho que a escrita é difícil, não acho que a escrita seja uma tarefa assim espontânea, fácil, e mais quando você tem algum tipo de exigência acadêmica”. PE15 também percebe a escrita como um sistema complexo, como um processo de construção. Afirma que: "a maior dificuldade, portanto é essa: fazer com que eles entendam que fazer texto é um processo lento, de construção, de idas e vindas, de consulta a materiais diversos, manuais diversos... que as dúvidas que eles apresentam podem ser sanadas e que, principalmente, o branco (Ai, professor, me deu um branco!) só existe quando não se domina um assunto (falta de leitura e conhecimento de mundo), quando se tem 
timidez de mostrar um texto escrito, temendo o julgamento do professor, ou quando, de fato, somos invadidos por uma ansiedade ou nervosismo tão grandes que o texto empaca. Acontece! Mas é menos comum, se você está embasado, bem informado”.

P10 já percebe a escrita como transmissão de pensamento e relata como desenvolve suas atividades: "Trabalho no sentido que uma das minhas questões é que o pensamento, as conclusões das pessoas, as ideias estejam claras, que eu consiga compreender, a partir da escrita, a mensagem que eles tentaram transmitir".

P4 já percebe além de transmissão, uma organização do pensamento. Ele diz: "Eu acho que quando você escreve, especialmente quando você escreve sozinho, você é obrigado a organizar seu pensamento em relação àquele tema ou àquela leitura ou à discussão que está acontecendo etc. Você organiza uma determinada linha de argumentação, e isso é muito importante" e completa suas ideias ao dizer que "a escrita ela expressa, em certa medida, uma organização do pensamento sobre os mais variados temas em primeiro lugar". Além disso, P4 trabalha com a ideia da escrita como forma de comunicação social e transmissão de conteúdos, principalmente em se tratando da profissão docente: “ela (a escrita) precisa comunicar claramente, isso é, para um futuro professor, comunicar claramente é fundamental. Ele tem que desenvolver seus alunos e eventualmente ele vai trazer conteúdos para comunicar aos alunos também, tem que informar os alunos sobre uma série de coisas, então ele precisa saber fazer isso com clareza. Então uma parte disso se desenvolve também na linguagem escrita".

P11 concebe a escrita como argumentação e é o único que afirma claramente que questões gramaticais não são o foco de seu trabalho e que essa postura não é geral entre os docentes: "eu não foco tanto na gramática, coisas desse tipo, mas eu tô muito preocupado com organização do trabalho, encaminhamento do trabalho, de discussão, de argumento, se eles têm ou não têm um argumento, uma posição, ou seja, como se colocar no mundo pela escrita." Acrescenta ainda que: " eu considero esse tipo de organização, encaminhamento, mais importante do que probleminhas de gramática para falar a verdade, porque estamos falando aqui da organização da cabeça das pessoas. Todo mundo pode falhar em gramática aqui ou ali, mas mais 
sério para mim é uma pessoa que não sabe colocar uma ideia logicamente atrás da outra, pode ter uma gramática perfeita, mas se não é capaz de fazer isso adianta o quê?."

P12 corrobora a ideia do participante anterior ao indicar que: "[...] a escrita me ajuda a estruturar meu pensamento. Eu penso com mais clareza, com mais coerência quando eu consigo escrever sobre aquilo que eu estou pensando", e prossegue assegurando: "eu acho que quando eu consigo estruturar a escrita, eu consigo pensar melhor, eu consigo arrumar aquilo que eu penso, eu consigo arrumar melhor os meus argumentos, arrumar melhor as minhas ideias, e se eu produzo textos confusos, é difícil eu conseguir me organizar e me arrumar." Além disso, P12 é o único que menciona a importância da escrita como forma de prazer, ao afirmar " [...] acho que tem um segundo aspecto que é esse de encontrar na escrita um certo prazer, um certo lugar talvez dentro da escrita que isso vai ser um dos seus instrumentos e objetivos de trabalho depois, e eu não tenho como escapar disso." Apesar de P12 não ser um dos professores das disciplinas específicas estudadas, ele é o único que menciona o prazer, o desejo, na escrita, que é justamente o que as estudantes participantes da entrevista coletiva da disciplina optativa revelaram: descobrir a escrita autoral, sem obrigação, com vontade de estar fazendo e querer fazer aquilo - escrever - como será demonstrado adiante.

Outro docente que também percebe a escrita como argumentação é P7, que prioriza a capacidade de defesa de argumentos: "eu acho que a escrita é um dos aspectos mais importantes. Eu acho que tão importante quanto a capacidade de escrever é defender, nessa escrita, as suas posições, os seus argumentos". Além disso, também deixa claro que acredita que cada área de conhecimento tem suas especificidades na produção escrita. David Russell ${ }^{17}$, em entrevista para Ramos e Espeiorin (2009), corrobora a ideia de que o professor precisa ensinar o aluno a se comunicar nas mais diversas áreas do conhecimento.

${ }^{17}$ David Russell é um linguista norte-americano, professor de Inglês da Universidade de Iowa. O pesquisador é interessado por escrita profissional, instrução para a escrita internacional e a história da escrita. 
PE13 também apresentou duas visões novas: a escrita como poder e a escrita como um processo cognitivo. Menciona que "a leitura e a escrita são instrumentos de poder, são instrumentos de trânsito social, de 'poder' nesse sentido" $\mathrm{e}$ complementa sua percepção ao mencionar que a escrita faz parte de uma estrutura maior, de grande complexidade e integrante de nossa parte cognitiva: "Ela é importante inclusive estruturalmente, porque ela compõe estruturas cognitivas, ela compõe o processo cognitivo. Linguagem configura pensamento, então a escrita também configura pensamento, e isso era uma coisa que eu dizia sempre para elas, que o trabalho com a leitura e a escrita não era só uma questão de prazer e de repertório, embora isso também fosse importante, mas era de configuração de estruturas cognitivas".

P5, por outro lado, apresenta um ponto de vista um tanto mais formal, apesar de também sugerir que o processo não é automático e que ser capaz de colocar e organizar argumentos é fundamental. Ao afirmar que a escrita é: “muito importante, como aprender a comunicar-se em uma linguagem formal, e eles estão em uma universidade, eles participam do mundo acadêmico, eles têm que saber escrever um português correto", completa suas convicções dizendo que: "Eu acho que mesmo para quem não vai fazer uma carreira acadêmica, trabalhar mesmo em escola, é importantíssimo você... com a escrita você também trabalha a questão da sua argumentação, porque você é obrigado a pensar para poder escrever, não é uma coisa automática, e nesse momento você tem que saber colocar seus argumentos, $e$ isso que muitas vezes eu sinto falta, saber trazer a sua bagagem cultural para poder expor corretamente, defender seu ponto de vista”.

Para Geraldi (2011) existem basicamente três concepções de linguagem:

a. Linguagem como expressão de pensamento;

b. Linguagem como instrumento de comunicação; e

c. Linguagem como forma de interação.

Se observarmos as percepções dos professores, poderemos concluir que a maioria percebe a escrita como expressão de pensamento. Para Geraldi (2011, p. 41), essa primeira postura está intimamente relacionada aos aspectos tradicionais da 
língua e quando "concebemos a linguagem como tal, somos levados a afirmações correntes - de que pessoas que não conseguem se expressar não pensam”. $\mathrm{Na}$ segunda postura, a língua é um código e tem como objetivo transmitir mensagens entre atores. A última concepção é a mais abrangente de todas, visto que além de possibilitar a comunicação, a linguagem também é percebida como lugar de interação social e humana.

\subsubsection{Relação entre leitura e escrita}

Para Leta (2005), ler e escrever não podem ser consideradas habilidades de características iguais. Existem diferenças que envolvem os dois processos, ditos diversos, porém complementares. Conforme afirma Marinho (2010, p. 369), "ler e escrever são atividades complementares, em que apenas se alterna o lugar de proeminência de uma delas, em um determinado momento da atividade de linguagem".

Kramer (1999) percebe a leitura e a escrita como experiências, pois acredita que são ações que não se esgotam em determinado tempo. Ao contrário, são ações infinitas, que não se limitam a um espaço de tempo. Interessa-se pela leitura como “algo que passa para além do seu tempo de realização" (KRAMER, 1999, p. 106). Acrescenta ainda que "sendo mediata ou mediadora, a leitura leva o sujeito para além do dado imediato, permite pensar, ser crítico da situação, relacionar o antes e o depois, entender a história [...]" (KRAMER, 1999, p. 107).

Do mesmo modo, Kramer (1999, p. 110) afirma que a escrita é experiência, visto que "tanto quem escreve quanto quem lê enraízam-se numa corrente". Declara que:

Escrever significa sempre (re) escrever, interferir no processo, deixar-se marcar pelos traços do vivido e da escrita. (Re) escrever texto e histórias, ser leitor de textos escritos e da própria história pessoal e coletiva, marcando-a, mudando-a, inscrevendo nela novos sentidos. (KRAMER, 1999, p. 110) 
Geraldi (2011), ao tratar sobre a prática de leitura, discute o espaço da leitura e da escrita em nossa sociedade, afirmando que a leitura por fruição, por prazer, hoje em dia, não encontra mais espaço de existência. A escola, acompanhando esse "desenvolvimento", acaba por suprimir esse tipo de atividade, explorando apenas o "necessário", conforme as suas crenças. O autor pretende destacar a importância da leitura gratuita, sem espera de resultados 'controlados', mas simplesmente pela vontade de estar engajado, informado. Certamente, todo esse processo gera frutos vantajosos sobre os conhecimentos acumulados, constante na memória, de uma pessoa.

Observe-se como a leitura e a escrita de fato se complementam. A respeito disso, não nos restam dúvidas. Leitura e escrita desempenham, de fato, importante papel na formação de professores. Porém, assim como no estudo de Leta (2005), conforme já indicado anteriormente, o interesse deste estudo consiste nas percepções sobre a escrita e sua importância para o exercício da profissão docente. Mesmo assim, não há como ignorar que a discussão entre leitura e escrita apareceu frequentemente no depoimento de quatro professores. Os professores afirmam que a leitura influencia o processo de escrita, facilitando-o, e que esses são processos complementares.

P4 afirma: "[...] eu sempre digo que a boa leitura ajuda a boa escrita, eu sempre achei isso, seja a leitura de jornal, embora os jornais hoje em dia às vezes também vêm com textos ruins, a leitura de literatura ou qualquer leitura sempre ajuda"; P6 chega até mesmo a criticar o Curso em questão, indicando a falta de estímulo para a leitura,: "[...] eu acho que a leitura e a escrita elas caminham juntas, então eu acho importante pensar assim 'você, professora, é uma leitora?', se você não for uma leitora será que você vai conseguir passar o amor pela leitura, a importância da leitura, então eu acho que isso talvez o curso pudesse fazer mais"; P12 assegura: "[...] eu acredito, de fato, que a gente desenvolve a escrita escrevendo e sofrendo intervenções nessa escrita. Agora a leitura alimenta a escrita, a leitura me ajuda a ter repertório para escrever, me ajuda nas questões ortográficas, 
gramaticais e de estrutura, enfim, então cuidar do tipo de leitura que eu ofereço pode fazer parte disso".

PE15 discute sobre a complementaridade da leitura e da escrita: "[...] não dá para falar estritamente de escrita sem falar de leitura. Ambas devem caminhar juntas. E, particularmente, acho que um erro hoje é ver alguns profissionais polarizando uma e outra, sem a compreensão de que elas se complementam; Não adianta querer fazer escrever quem não tem o que dizer. Lendo, o aluno, além de se informar, passa a ter contato com estruturas complexas, bem organizadas. Acho que no fundo todo escritor se inspira em algum autor. Seja no estilo, na forma mais técnica. Então, é preciso diversificar, mostrar caminhos. Motivar a ler. Eu iria além: ensinar a ler. Esmiuçar os parágrafos junto com os alunos, pensar na palavra, quebrá-la ao meio, ver o que significa".

Essa discussão sobre a relação entre leitura e escrita não aparece de forma clara nas entrevistas das estudantes. Como será demonstrado em tópico posteriores, as alunas mencionam a importância da leitura, mas não estabelecem relações explícitas com a escrita. Em geral, quando mencionam a leitura, fazem referência ao trabalho do regente da turma no sentido de incentivar o gosto pela leitura.

\subsection{Relação das disciplinas da Pedagogia com a escrita}

Para Bechara (2006, p. 60), "tem-se de compreender que o professor de português não é o único agente de que dispõe a escola para deflagrar o aprendizado da língua vernácula”.

As entrevistas realizadas nesta pesquisa com os docentes do curso de Pedagogia constataram que todos acreditam que o trabalho a ser realizado com e sobre a Língua Portuguesa pode ser realizado por professores das diversas áreas de conhecimento. Santos (2006) corrobora essa perspectiva. 
A partir da percepção dessas ideias, buscamos apontar como os estudantes se autoavaliam e como é realizado o trabalho do professor em sala de aula no sentido de percepção e intervenção nas dificuldades dos alunos.

\subsubsection{Dificuldades apresentadas: avaliação dos discentes e dos docentes}

Em relação às dificuldades ${ }^{18}$ que o grupo de alunas como um todo apresenta, o quadro a seguir é explicativo. As participantes poderiam marcar a quantidade de opções que considerassem necessária. Foram no total 60 marcações, entre as 26 participantes. Observe-se o quadro ilustrativo abaixo:

Tabela 5. Maiores dificuldades na produção escrita - autoavaliação das alunas

\begin{tabular}{lc}
\hline Opções de Resposta & Frequência \\
\hline Organização de ideias no texto & 17 \\
Crase & 13 \\
Pontuação & 11 \\
Ortografia & 7 \\
Concordância verbal e nominal & 7 \\
Regência verbal & 4 \\
Outros: Vocabulário amplo & 1 \\
\hline
\end{tabular}

Como o quadro mostra, os itens mais significativamente selecionados como difíceis foram: organização de ideias no texto, crase e pontuação. A única aluna que indicou uma outra opção foi a Estudante 16PB, que mencionou vocabulário amplo, que provavelmente refere-se à falta de conhecimentos prévios sobre determinados assuntos relacionados ao campo educacional, podendo ser enquadrada como dificuldade conceitual.

\footnotetext{
${ }^{18}$ Nos itens foram enfatizados aspectos relativos à norma padrão da Língua. Em trabalhos futuros, será importante ampliar as opções de resposta incluindo itens mais diretamente ligados à construção do texto em si, como à coesão e coerência textuais. Apesar disso, fica claro que os aspectos gramaticais dividem espaço com aspecto global/macroestrutural, ligado à organização de ideias no texto, o que sugere que os alunos têm uma visão de escrita mais abrangente.
} 
É interessante observar que este é um cenário que vai ao encontro da posição dos docentes do curso sobre as maiores dificuldades que são observadas. Para eles, a organização de ideias no texto é observada como maior área de incidência de dificuldades. Além disso, a área gramatical também é definida como problemática. Com os professores, entretanto, foi possível realizar uma distribuição das dificuldades de modo mais elaborado. Através de seus depoimentos, foi possível estabelecer uma categorização diferente:

1. Questões de autoria, no sentido de construção própria, de posicionamento do aluno;

2. Questões organizacionais, no sentido de estruturação do texto, das ideias;

3. Questões conceituais; e, no sentido de aprendizagem do conteúdo da matéria, vocabulário especializado

4. Questões gramaticais.

Observemos, agora, a distribuição das respostas obtidas:

Quadro 8. Definição das dificuldades dos alunos pelos docentes

\begin{tabular}{|c|c|c|c|c|}
\hline \multirow{2}{*}{ Professor } & \multicolumn{4}{|c|}{ Dificuldades } \\
\hline & Autoria & Organizacionais & Conceituais & Gramaticais \\
\hline P1 & - & Parágrafos longos & - & $\begin{array}{l}\text { Crase; erros de } \\
\text { concordância }\end{array}$ \\
\hline P2 & \multicolumn{4}{|c|}{ Não respondeu } \\
\hline P3 & - & - & - & Erros mesmo \\
\hline P4 & - & Expressão escrita & - & - \\
\hline P5 & - & Construções inadequadas & - & $\begin{array}{c}\text { Advérbio, } \\
\text { pontuação e acento }\end{array}$ \\
\hline P6 & $\begin{array}{c}\text { Falta } \\
\text { autoria }\end{array}$ & Texto desarticulado & - & 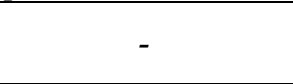 \\
\hline P7 & $\begin{array}{c}\text { Falta } \\
\text { autoria }\end{array}$ & Texto desarticulado & $\begin{array}{c}\text { Citações } \\
\text { inadequadas }\end{array}$ & - \\
\hline P8 & - & - & $\begin{array}{c}\text { Vocabulário } \\
\text { fraco }\end{array}$ & Regras gramaticais \\
\hline P9 & - & - & & Erros mais comuns \\
\hline P10 & - & $\begin{array}{c}\text { Textos truncados; ideias } \\
\text { repetidas }\end{array}$ & - & - \\
\hline
\end{tabular}




\begin{tabular}{|c|c|c|c|c|}
\hline P11 & $\begin{array}{c}\text { Falta } \\
\text { autoria }\end{array}$ & $\begin{array}{c}\text { Planejamento textual; } \\
\text { dificuldade de composição }\end{array}$ & - & - \\
\hline P12 & - & $\begin{array}{c}\text { Falta de clareza nas ideias; } \\
\text { dificuldade de composição }\end{array}$ & - & - \\
\hline PE13 & - & $\begin{array}{c}\text { Expressão em lingua escrita do } \\
\text { pensamento }\end{array}$ & - & $\begin{array}{c}\text { É o que mais } \\
\text { compromete }\end{array}$ \\
\hline PE14 & - & $\begin{array}{c}\text { Planejamento textual; } \\
\text { argumentação superficial }\end{array}$ & - & Pontuação* \\
\hline PE15 & - & $\begin{array}{c}\text { Perceber a escrita como } \\
\text { processo de construção }\end{array}$ & - & - \\
\hline
\end{tabular}

(conclusão)

P2 foi o único que não respondeu à questão.

Observe que P4 utiliza o termo expressão escrita, enquanto PE13 utiliza a construção expressão em língua escrita do pensamento. De modo geral, ambas as citações fazem referência a um mesmo objeto. Porém, optou-se aqui por exemplificar de forma direta suas considerações e, portanto, optamos por utilizar os termos exatos de que os docentes fizeram uso. Enquanto P4 afirma que "é muito comum encontrar grande dificuldade de expressão escrita nos alunos”, PE13, no mesmo sentido, acrescenta que existe "uma certa dificuldade, porque elas se expressam bem oralmente, então é uma certa dificuldade de expressão em língua escrita do pensamento; porque quando eu lia com elas o trabalho delas eu dizia 'mas o que você quis dizer?', e aí oralmente ela é capaz de dizer muito bem o que ela quis dizer, mas a frase não deu conta disso".

As dificuldades organizacionais também foram mencionadas por outros professores. P1 fala sobre o problema que parágrafos longos causam na compreensão de um texto: "são parágrafos muito longos e que, por serem muito longos, o próprio autor se perde na ideia, não chega a concluir, não chega a passar para o leitor a ideia que ele está querendo registrar". Enquanto P5 menciona que percebe muitas frases inadequadamente construídas, também percebe dificuldades gramaticais, com muitos erros de advérbio, pontuação e acento, P6 e P7 atentam para a questão da coerência textual, para os textos que são desarticulados. P6 diz: "eu acho assim o texto desarticulado, com saltos, com rupturas do ponto de vista da estrutura do texto, não tem uma unidade, acho que isso é um problema para mim, é mais do que a 
regra". Já P7 aponta como dificuldade organizacional: "não conseguir estabelecer um diálogo entre os textos num determinado momento, uma articulação entre os textos".

Nesse mesmo sentido, P10 também percebe "textos truncados, às vezes textos com ideias repetidas, uma dificuldade em relação à síntese". P12 menciona a falta de clareza nas ideias, a progressão temática e a coerência textual e relata: "É engraçado isso, você pega o texto... ele é um texto que eu vou chamar de limpo. A escrita está ali, está estruturada, ortograficamente, enfim a estrutura do texto está ali, mas a clareza das ideias, às vezes, elas ficam truncadas. Textos que, às vezes, rodam, rodam, rodam e não chegam em um ponto que precisa ser tratado".

P11 entrelaça dois aspectos importantes na organização textual: a capacidade de planejamento e de composição. O professor relata que o aluno precisa iniciar a produção de um texto e, ao final, revisar todo o conteúdo produzido com o objetivo da adequação. Diz ele: "Quando eu exijo minimamente duas mil palavras eles ficam loucos. Depois o problema que eles têm de mostrar a fazer isso, é como reduzir para duas mil palavras, mas a reação inicial é 'eu nunca vou conseguir escrever isso' porque eles não sabem como compor uma coisa desse tipo. Depois de saber disso, o que rola é o inverso, como reduzir, ou seja, tirar coisas que não são necessárias".

Nessa mesma linha, PE14 afirma que a dificuldade de planejamento textual é comum em quase todos os alunos e que esse, junto à argumentação superficial, é um grande problema que exige maior tempo e preocupação de trabalho. Sobre a questão do tempo, PE15 concorda com PE14 e declara que a maior dificuldade consiste em demonstrar que "fazer texto é um processo lento, de construção, de idas e vindas, de consulta a materiais diversos, manuais diversos... que as dúvidas que eles apresentam podem ser sanadas e que, principalmente, o branco (Ai, professor, me deu um branco!) só existe quando não se domina um assunto (falta de leitura e conhecimento de mundo), quando se tem timidez de mostrar um texto escrito, temendo o julgamento do professor, ou quando, de fato, somos invadidos por uma ansiedade ou nervosismo tão grandes que o texto empaca”. Observe que PE15 
também ressalta aspectos de ordem emocional que também podem afetar a produção de um texto escrito, como o nervosismo e a ansiedade.

A respeito das dificuldades gramaticais, foram seis professores que as mencionaram. P1 declara que percebe maiores dificuldades nos quesitos crase e concordância: "As crases são um problema generalizado, crase é uma coisa muito difícil, é engraçado, mas isso acontece em todos os níveis de formação, digamos assim, pelo menos é o que eu tenho visto; Também são erros de concordância, que também existem, são bastante frequentes". P5 traz a questão do advérbio, da acentuação e da pontuação: "Saber o local correto do advérbio, utilização de pontuação, saber aonde usa acento e não, no lugar de eles usarem o 'que', eles usam o onde, o gerúndio". P9 foca aspectos semelhantes: "o uso de vírgula, por exemplo, então separar sujeito e verbo com vírgula. O uso de conectivos, por exemplo, ao invés de 'que', 'onde'. Às vezes erros de concordância, se o verbo estiver muito longe do sujeito aí perde a noção da concordância. São os erros mais comuns assim”.

Os professores 3, 8 e 13 foram os mais abrangentes nessa categoria e englobaram as dificuldades gramaticais como um todo. Enquanto P3 menciona que percebe "erro mesmo, na escrita, estou falando de coisa simples, mas que precisam ser aprendidos, sujeito, predicado, concordância verbal, acento, erro muito mais nesse sentido", P8 aponta que as regras gramaticais são desconhecidas: "formulação ortográfica, concordâncias, acentos, hifens, todas essas regras gramaticais. As regras gramaticais são muito desconhecidas e tem muitas dúvidas, onde colocar uma crase". Para coroar essa categoria, PE13 afirma que "o aspecto gramatical é o que mais compromete, que é a estrutura da frase, aspecto gramatical nesse sentido, você conseguir construir uma frase que efetivamente expresse seu pensamento de maneira compreensível, de maneira clara, de maneira precisa. Eu não encontrei assim grandes erros ortográficos, coisas pequenas ou, às vezes, de conjugação, mas me parece, uma das coisas que eu notei, que muitas vezes o erro de conjugação é que uma frase que forma o parágrafo inteiro, uma frase só, então quando tá lá na terceira linha, quarta linha da frase, já não sabe mais qual é o sujeito daquela frase. 
Acho que também pontuação, por isso, essas frases enormes, às vezes tem uma questão de pontuação".

Para dois docentes, P10 e PE14, a ortografia não pode ser considerada um problema. Enquanto o primeiro afirma que a tecnologia auxilia os alunos nesse sentido e os trabalhos manuscritos realizados são poucos, o segundo já sugere que os alunos "estão chegando com uma ortografia até razoável”. Observe, porém, no quadro acima, que enquanto P10 não indicou qualquer tipo de dificuldade gramatical, PE14 ainda assim indicou a pontuação como sendo difícil para os alunos.

Quanto às dificuldades conceituais, apenas dois professores - P7 e P8 relataram dois casos que remetem ao assunto. Enquanto P7 afirma que o que o incomoda é um aluno não saber citar adequadamente autores, demonstrando falta de domínio no assunto, P8 relaciona o vocabulário fraco dos alunos com a falta de leitura que os mesmos possuem.

As dificuldades de autoria que pudemos observar no quadro anterior fazem referência à falta de capacidade do aluno de se impor em seu próprio texto. P6 afirma que falta "a capacidade de fazer uma análise crítica, de não reproduzir só o que o autor pensa"; P11 indica que "A tendência é tentar se esconder atrás do texto dos outros"; e P7, por sua vez, relata: "Se eu peço para um aluno fazer uma apreciação pessoal sobre um texto não há necessidade nenhuma desse aluno ir na internet $e$ copiar alguma coisa”.

A questão da autoria passa também pela legitimação da voz do próprio aluno que, por sua vez, não consegue se perceber no lugar de autor, mas sim de reprodutor. De acordo com Silva (2008),

Nessa perspectiva, cada vez que a universidade ignora a necessidade da viabilização de projetos que engendrem práticas de leitura/escrita com vistas à construção da autonomia do aluno para responder pelo que diz e pelo que escreve, leva-o à não-consciência do outro, à negação da autoria, da identidade do outro; e, conseqüentemente, a seu silenciamento como autor [...].(SILVA, 2008, p. 365) 
Observe que esse é um assunto que está relacionado com a base de conhecimentos e de leitura de um indivíduo. O aluno, para ganhar autoria, para construir sua própria voz, precisa conhecer várias faces de um assunto, precisa ampliar seu conhecimento de mundo. Desse modo, ao escrever, ele irá registrar suas marcas nas suas produções e se constituirá como verdadeiro autor daquele texto.

E como esses professores classificam a frequência e a gravidade das dificuldades dos alunos? Alguns participantes não deram uma resposta direta para a questão: "Como você classificaria os problemas de produção escrita em geral dos estudantes em termos de grau de frequência e gravidade? (alta - média - baixa)”. De qualquer forma, foi possível consubstanciar os resultados no quadro abaixo.

\section{Quadro 9. Frequência e gravidade das dificuldades dos alunos, de acordo com os professores}

\begin{tabular}{|c|c|}
\hline Frequência/gravidade & Professores \\
\hline Alta/grave & P4, P5, P11 \\
\hline Alta/média & P1, P12 \\
\hline Alta/baixa & P8, P10 \\
\hline Média/Média & $\begin{array}{c}\text { P2, P3, P6, PE13, } \\
\text { PE14, PE15 }\end{array}$ \\
\hline Baixa/alta & P7 \\
\hline Baixa/média & -- \\
\hline Baixa/baixa & P9 \\
\hline
\end{tabular}

$\mathrm{Na}$ realidade, como é possível observar, não existe um consenso sobre o assunto. Porém, de modo geral, podemos caracterizar a frequência e gravidades dos erros e dificuldades encontrados com grau médio. Mas então, como os professores atuam no sentido de auxiliar os alunos que apresentam dificuldades? Na questão 11 do questionário as estudantes afirmam que os professores nunca ou raramente conversam com os alunos individualmente (8 e 10 participantes, respectivamente). Além disso, 21 estudantes afirmam que nunca ou raramente os professores orientam os alunos com dificuldades a procurarem um apoio de outro professor, sendo ele do curso ou não. 
Tabela 6. Apreciação das práticas comuns entre os professores pelos discentes ${ }^{19}$

\begin{tabular}{|c|c|c|c|c|c|c|}
\hline Opção de resposta & $\mathbf{N}$ & $\mathbf{R}$ & AV & $\mathbf{F}$ & $\mathbf{S}$ & $\mathbf{N R}$ \\
\hline Corrigem erros de escrita & 0 & 2 & 6 & 11 & 7 & 0 \\
\hline Demonstram preocupação com a ortografia & 0 & 2 & 9 & 4 & 11 & 0 \\
\hline $\begin{array}{l}\text { Realizam marcações de erros ou incoerências nos } \\
\text { textos. }\end{array}$ & 0 & 1 & 7 & 8 & 10 & 0 \\
\hline Realizam exercícios de produção textual & 1 & 3 & 3 & 10 & 8 & 1 \\
\hline $\begin{array}{l}\text { Demonstram preocupação com a qualidade da } \\
\text { escrita. }\end{array}$ & 0 & 0 & 7 & 10 & 9 & 0 \\
\hline $\begin{array}{l}\text { Demonstram preocupação com a organização de } \\
\text { ideias }\end{array}$ & 0 & 1 & 4 & 10 & 11 & 0 \\
\hline $\begin{array}{l}\text { Orientam os alunos com mais dificuldades a } \\
\text { procurarem um apoio de outro professor, sendo ele } \\
\text { do curso ou não. }\end{array}$ & 12 & 9 & 5 & 0 & 0 & 0 \\
\hline $\begin{array}{l}\text { Orientam os alunos com mais dificuldades a } \\
\text { procurarem um apoio fora da universidade. }\end{array}$ & 15 & 5 & 5 & 0 & 0 & 1 \\
\hline Conversam com os alunos individualmente & 8 & 10 & 7 & 0 & 1 & 0 \\
\hline $\begin{array}{l}\text { Conversam com os alunos coletivamente sobre } \\
\text { problemas de escrita. }\end{array}$ & 6 & 6 & 8 & 5 & 1 & 0 \\
\hline $\begin{array}{l}\text { Reserva um tempo para explicação de problemas de } \\
\text { escrita }\end{array}$ & 4 & 13 & 5 & 2 & 0 & 2 \\
\hline Solicitam reescrita de um trabalho & 5 & 11 & 5 & 3 & 2 & 0 \\
\hline $\begin{array}{l}\text { Demonstram preocupação apenas com o conteúdo do } \\
\text { trabalho. }\end{array}$ & 5 & 5 & 7 & 5 & 4 & 0 \\
\hline $\begin{array}{l}\text { Expõem publicamente os problemas, causando por } \\
\text { vezes constrangimentos }\end{array}$ & 19 & 5 & 2 & 0 & 0 & 0 \\
\hline
\end{tabular}

Para a maioria das alunas, os professores corrigem frequentemente os erros de escrita. Nenhuma aluna afirmou que essa correção não ocorre nunca. Entretanto, consideram que os professores raramente reservam um tempo para explicação de problemas de escrita. Quanto a conversar com os alunos individualmente, há divergência significativa entre as respostas dadas pelas alunas sobre a atuação dos professores, pois as respostas variam entre 'nunca', 'raramente' e 'às vezes'. Da mesma forma, sobre conversar com os alunos coletivamente, também há divergência

1919 Códigos para identificação: $\mathrm{N}=$ nunca; $\mathrm{R}=$ raramente; $\mathrm{AV}=$ às vezes; $\mathrm{F}=$ frequentemente; $\mathrm{S}=$ sempre; $\mathrm{NR}$ = não respondeu 
entre as alunas, pois as respostas variam entre 'nunca', 'raramente', 'às vezes' e 'frequentemente'.

De acordo com a maioria das discentes, os professores costumam realizar marcações de erros ou incoerências nos textos, o que ocorre 'sempre ou 'frequentemente'. Afirmam também que os professores realizam exercícios de produção textual no mesmo ritmo. Os professores preponderantemente nunca ou raramente orientam os alunos com mais dificuldades a procurarem apoio de outro professor, assim como não o fazem sobre a procura por apoio fora da universidade. Há divergência entre as alunas quanto ao fato de os professores demonstrarem preocupação apenas com o conteúdo do trabalho, com respostas entre 'nunca' e 'sempre'.

Os professores demonstram preocupação com a qualidade da escrita e com organização de ideias frequentemente ou sempre, além de demonstrarem preocupação com a ortografia relativamente de forma frequente. Para a maioria das participantes, os docentes nunca expõem publicamente os problemas e raramente solicitam a reescrita de um trabalho.

Se observamos mais atentamente a Tabela 6 , será possível constatar que a atuação dos professores, na visão dos alunos, está polarizada em dois aspectos. Se por um lado é possível perceber que os professores atuam mais fortemente quando o assunto é o trabalho escrito do aluno, com as respostas variando entre sempre e frequentemente, por outro lado, também observamos que quando o trabalho do docente está direcionado para uma atenção personalizada ao aluno, a frequência fica reduzida a nunca ou raramente.

É interessante observar que as alunas participantes da entrevista mais uma vez ratificam algumas posições que estão desdobradas em vários tópicos deste trabalho, só que desta vez de forma mais clara. $\mathrm{Na}$ entrevista, quando solicitadas a qualificarem como os professores das disciplinas gerais do Curso de Pedagogia manifestam interesse em saber o progresso de seu desenvolvimento, afirmam que alguns professores não podem ser considerados como exemplo de docência, que a maioria dos professores não demonstra preocupação, interesse, no desenvolvimento do aluno 
e que quando isso ocorre é geralmente nos períodos iniciais. Afirmam que não são professores acessíveis, com os quais têm dificuldades de estabelecer contato, de conversar.

Quadro 10. Avaliação das alunas das manifestações dos professores sobre seu desenvolvimento na escrita

\begin{tabular}{|c|c|}
\hline Participante & Depoimento \\
\hline Estudante & $\begin{array}{l}\begin{array}{l}\text { Eles não manifestam nada, pelo menos comigo. Poucas são as } \\
\text { (disciplinas) que conversam. }\end{array} \\
\text { (a) }\end{array}$ \\
\hline Estudante & $\begin{array}{l}\text { Em alguns poucos sim, mas não da maneira como ela faz. É muito } \\
\text { limitado, ele até para e ouve, mas não quer dizer que ele vá considerar, } \\
\text { que ele vá explicar, que é uma outra questão. Não é um curso que as } \\
\text { disciplinas conversam entre, si são muito fragmentadas, é cada um no seu } \\
\text { espaço. Assim, o que eu vejo nessa disciplina, é alguns professores da } \\
\text { Pedagogia, alguns são exemplo do que se deve fazer, do que você } \\
\text { aprende, do que você estuda, e alguns não, porque o que ele fala é uma } \\
\text { coisa e o que ele ensina é outra coisa totalmente diferente. Então ele } \\
\text { ensina uma coisa, mas ele enquanto professor, a didática dele, a } \\
\text { metodologia dele não condiz com aquilo que ele está ensinando. Muito } \\
\text { poucas. Tem a questão de 'eu vou na sua aula, dou palestra e tal', mas } \\
\text { quando se trata de fazer esse diálogo eu nunca vi não. }\end{array}$ \\
\hline $\begin{array}{l}\text { Estudante } \\
\quad 20\end{array}$ & $\begin{array}{l}\text { Mas acho que, no início, nos primeiros periodos são os que os professores } \\
\text { mais nos ajudam na hora de escrever, que mais pontuam, porque eles } \\
\text { entendem que a gente chegou agora e a gente tem mais dificuldade. No } \\
\text { inicio da faculdade é que eu tinha mais assim esse retorno na correção } \\
\text { dos trabalhos escritos. }\end{array}$ \\
\hline $\begin{array}{l}\text { Estudante } \\
\quad 21 P R\end{array}$ & $\begin{array}{l}\text { Tem uma professora que ela sempre comenta o progresso da turma em } \\
\text { geral em relação a isso, tanto a escrita quanto o se colocar ao falar para } \\
\text { a turma, tem uma professora que observa, mas que eu me lembre é a } \\
\text { unica. A maioria não comenta. }\end{array}$ \\
\hline
\end{tabular}

É interessante observar que sete professores do curso (P2, P4, P6, P9, P10, P11 e P12), apesar de todas as críticas que lhes são feitas em sua maioria, afirmam notar progressos nos alunos. Relacionam essa percepção ao fato de as turmas serem pequenas, de as turmas serem as mesmas em outras disciplinas anteriores, ao fato de os alunos darem algum tipo de retorno e estarem mais cuidadosos com suas produções. As respostas são basicamente as mesmas e volvem sempre a um tópico principal: a quantidade de alunos e o acompanhamento dos mesmos grupos por semestres seguidos. Veja alguns exemplos: 
Quadro 11. Percepção dos professores de progressos dos alunos

\begin{tabular}{|c|c|l|}
\hline P & Código & \multicolumn{1}{c|}{ Exemplo } \\
\hline P6 & $\begin{array}{c}\text { Alunos mais } \\
\text { cuidadosos }\end{array}$ & $\begin{array}{l}\text { Eu vejo nos textos, na qualidade dos textos, no esforço deles fazerem, às } \\
\text { vezes tem um textinho que aquele menino é mais fraco, ele traz maiores } \\
\text { fragilidades da graduação, que serão superadas não sei como, mas trazem } \\
\text { algumas marcas da escolarização. }\end{array}$ \\
\hline P2 & $\begin{array}{l}\text { Eu acho que ajuda porque eu tenho tido assim algum retorno, de alunos } \\
\text { voltarem, eu acho até graça eles falarem 'eu tenho saudade'. Ou o pessoal } \\
\text { quando faz concurso. Eu acho que há algum retorno dos alunos. É pena } \\
\text { porque antigamente as disciplinas eram oferecidas mais para o final do } \\
\text { curso, mas às vezes de um semestre para outro já faz alguma diferença. Às } \\
\text { vezes eu pego a mesma turma em dois semestres seguidos. As minhas } \\
\text { disciplinas estão alocadas mais no início do curso, mas se eu pudesse, por } \\
\text { exemplo, pegar um aluno mais no final, daria para você sentir melhor. Mas } \\
\text { eu acho que às vezes ao longo do semestre já faz alguma diferença. }\end{array}$ \\
\hline P10 & $\begin{array}{c}\text { Maior } \\
\text { acompanha } \\
\text { mento com } \\
\text { poucos } \\
\text { alunos }\end{array}$ & $\begin{array}{l}\text { Uma outra coisa interessante que eu acho é que são poucos alunos, então é } \\
\text { possivel você também acompanhar as pessoas, eles são seus alunos em } \\
\text { diferente periodos, às vezes em diferentes disciplinas. A turma que eu tồ } \\
\text { dando aula agora várias pessoas já foram meus alunos em outras } \\
\text { disciplinas, então você vai acompanhando, conhece as dificuldades daquela } \\
\text { pessoa então você já vai orientando ela em relação a essas questôes. }\end{array}$ \\
\hline
\end{tabular}

Aliás, é interessante observar que a quantidade de alunos é um aspecto bastante citado pela maioria dos professores. De fato, o curso de Pedagogia tem turmas pequenas (entre 12 e 30 alunos), o que permite uma maior aproximação ao professor.

Entretanto, isso não significa que o acompanhamento ocorre de fato, como deixa em aberto P2 ao dizer que a quantidade de alunos: "Favorece, porque a gente tem grupos pequenos. Isso eu acho que favorece. Eu acho que se a gente quisesse investir mesmo, de verdade, porque as turmas nossas, você vê, por exemplo, uma turma com treze alunos, eu mais ou menos identifico direitinho, sei quem é que tem algum tipo de problema. As nossas turmas raramente chegam a 30 alunos, então eu acho que a gente teria possibilidade de desenvolver um trabalho bem interessante com os alunos porque você acaba quase que dando um atendimento mais personalizado, porque os grupos são pequenos".

\subsubsection{Correções: o quê e como?}


Com todo esse panorama de análise das dificuldades dos alunos, os docentes foram questionados sobre quais aspectos atentam na correção e como realizam tal. Por uma questão didática, optou-se por tabular esses resultados, objetivando uma melhor visualização.

Foi possível categorizar as correções em dois grupos: de gramática e de organização. Os aspectos gramaticais envolvem questões de ortografia, pontuação, regência, concordância e acentuação. Já os aspectos organizacionais abrangem tópicos relacionados à coerência e coesão, organização de ideias no texto, entre outros, conforme apontado na seção anterior (4.3.1.).

Alguns professores também mencionaram correções de aspectos conceituais, enquanto outros não. Porém, assumimos que esse tipo de correção faz parte do trabalho de todo professor visto que está atrelado ao aprendizado do conteúdo da matéria e, por isso, decidimos não marcar esse aspecto. Vejamos, abaixo, quais professores afirmam os aspectos que observam e corrigem nas produções dos alunos:

\section{Quadro 12. Aspectos que os professores corrigem nas produções textuais}

\begin{tabular}{|c|c|c|}
\hline \multirow{2}{*}{ Professor } & \multicolumn{2}{|c|}{ Aspectos que corrige } \\
\cline { 2 - 3 } & Gramaticais & Organizacionais \\
\hline P1 & & $\mathrm{x}$ \\
\hline P2 & & $\mathrm{x}$ \\
\hline P3 & $\mathrm{x}$ & $\mathrm{X}$ \\
\hline P4* & & $\mathrm{x}$ \\
\hline P5 & $\mathrm{x}$ & \\
\hline P6 & \multicolumn{2}{|c|}{} \\
\hline P7 & \multicolumn{2}{|c|}{ Não respondeu } \\
\hline P8* & $\mathrm{x}$ & $\mathrm{x}$ \\
\hline P9 & $\mathrm{x}$ & $\mathrm{X}$ \\
\hline P10 & $\mathrm{x}$ & $\mathrm{x}$ \\
\hline P11 & $\mathrm{x}$ & $\mathrm{x}$ \\
\hline P12 & $\mathrm{x}$ & $\mathrm{x}$ \\
\hline PE13 & $\mathrm{x}$ & $\mathrm{x}$ \\
\hline PE14 & $\mathrm{x}$ & $\mathrm{x}$ \\
\hline PE15 & $\mathrm{x}$ & \\
\hline
\end{tabular}


Para dois professores (P4 e P8), a correção gramatical caracteriza-se como uma especialidade que eles não possuem. Ambos os professores aludem ao caráter técnico que a correção gramatical possui e afirmam que tal fato precisa ser trabalhado sim, mas com e por pessoas especializadas. Apesar de P8 afirmar realizar a correção de aspectos gramaticais, indica que essa correção ocorre apenas com erros graves, que dificultam a compreensão de um texto e P4 não indica realizar tal correção. P2, quanto às questões gramaticais, afirma que o aluno irá aprender a escrever escrevendo.

As formas como os professores realizam as correções são semelhantes. São ações que incorporam trabalhos tanto individuais como coletivos, apesar de o primeiro sobressair em relação ao segundo. Para tanto, verifique-se o quadro a seguir:

Quadro 13. Como os professores realizam correções

\begin{tabular}{|c|c|}
\hline Forma de correção & Professores \\
\hline \multirow{2}{*}{ Nos próprios textos, individualmente } & $\begin{array}{c}\text { P1, P3, P4, P6, P7, P8, P9, } \\
\text { P10, P11, PE13, PE15 }\end{array}$ \\
\hline Coletivamente & P2, P12 \\
\hline Individual e coletivamente & P5, PE14 \\
\hline
\end{tabular}

Onze professores mencionam apenas realizar correções individuais, nos próprios textos e não indicam um diálogo maior com o aluno. Dois professores, P2 e P12, afirmam realizar correções apenas coletivas, com todo o grupo e enfatizam que isso ocorre principalmente quando percebem um problema que é comum. Já P3 aparenta ser o mais detalhista de todos e diz: "Eu leio cada linha, a cada linha que eu leio eu faço uma marca que naquela linha tem algo que eu sugiro em termos da escrita: um ponto, uma vírgula, tem uma crase”.

Como era de se esperar, os professores das disciplinas específicas estudadas neste trabalho são os que aludem a um trabalho mais específico em cima da escrita. São atitudes que refletem um trabalho que realizam durante todo o curso de modo crítico, com a intenção de dialogar verdadeiramente com o aluno sobre o processo de escrita. Observem-se as falas dos professores: 
Quadro 14. Como os professores das disciplinas específicas realizam correções

\begin{tabular}{|c|c|}
\hline Professor & Depoimento \\
\hline PE13 & $\begin{array}{l}\text { [...] eu corrigi junto, sentava com cada uma, como era pouquinho, eu lia com ela o } \\
\text { trabalho dela, e ia com elas tentando ver qual seria a melhor maneira de reescrever } \\
\text { aquela frase }\end{array}$ \\
\hline PE14 & $\begin{array}{l}\text { [...] eu levanto os erros que são comuns, e ai eu vou para o quadro ou falo sem dizer, e } \\
\text { realmente eu não guardo quem é que cometeu aquilo, quem foi que produziu aquilo, aí } \\
\text { eu vou mostrar o uso do 'você', por exemplo, indeterminado, que está sendo muito } \\
\text { utilizado na língua oral, então a maioria está cometendo esse erro, aí eu vou para o } \\
\text { quadro e mostro. Ás vezes eu peço permissão se eu posso ler, principalmente quando é } \\
\text { boa, 'olha só que resenha boa, fulano, posso ler?'. Às vezes é engraçado, eu procuro } \\
\text { ter uma relação muito fraterna com eles, 'ah professora, não lê não, pelo amor de } \\
\text { Deus', então eu não leio. Ás vezes eu estou falando e eles dizem 'esse erro foi meu', eu } \\
\text { falo 'você que está dizendo'. }\end{array}$ \\
\hline PE15 & $\begin{array}{l}\text { [...] eu sempre faço uma leitura do texto inteiro antes de sair marcando coisas. É } \\
\text { preciso ter uma ideia global do que o aluno construiu. Na segunda leitura volto } \\
\text { marcando. Às vezes faço uma terceira leitura em alguns casos que considero mais } \\
\text { complexos. }\end{array}$ \\
\hline
\end{tabular}

\subsubsection{Contextualização do modelo processual da escritura}

Com base nas dificuldades previamente indicadas pelos alunos e as avaliações dos professores quanto à frequência e gravidade dos problemas, junto às metodologias de correção, direciona-se o trabalho para uma compreensão da conexão das entrevistas das alunas das turmas da disciplina optativa com o processamento cognitivo da escrita.

Os dados revelam que algumas alunas, durante a avaliação da disciplina, indicam que ocorreu um trabalho voltado para a ampliação das bases de conhecimento armazenadas na memória de longo prazo. Ambos os professores que lecionaram atuaram no sentido de proporcionar aos estudantes acesso a "bens culturais" aos quais os mesmos não têm acesso cotidianamente, seja por qual motivo for. Enquanto PE13 apresentou uma perspectiva mais literária, focalizando a ampliação de repertório, a compreensão de diferentes linguagens, o conhecimento de diferentes gêneros textuais, PE15 trabalhou em um sentido mais prático: enfatizando a leitura e a escrita de forma dinâmica, tendo a gramática como um manual, de forma a desenvolver a autoria e promover o gosto pela leitura. Ambas as propostas foram 
recebidas e avaliadas positivamente pelos discentes, cada uma com suas especificidades.

Os professores utilizaram diferentes metodologias e recursos, trazendo inovações para a sala de aula universitária. Foi uma verdadeira ampliação de repertório cultural, de conhecimento de mundo. Observemos no quadro abaixo o que os docentes apontam nesse sentido:

Quadro 15. Propostas das disciplinas optativas relacionadas à ampliação das bases de
conhecimento da memória de longo prazo dos estudantes

\begin{tabular}{|c|c|}
\hline Docente & Depoimento \\
\hline PE13 & $\begin{array}{l}\text { "Primeiro a ampliação de repertório. A primeira coisa que eu pensei com a } \\
\text { disciplina, elas precisam ampliar o repertório literário. Meu foco foi Literatura, } \\
\text { elas têm que ter uma compreensão melhor dos gêneros literários e dos diferentes } \\
\text { modos de escrita associados a cada gênero e a cada, dentro dos próprios } \\
\text { gêneros, a cada formato, não sei bem se a palavra é essa, mas o que eu queria é } \\
\text { que elas pudessem compreender o que que é um poema e como se analisa um } \\
\text { poema, e quais são os critérios de qualidade que são adotados para se avaliar a } \\
\text { qualidade de um poema. A mesma coisa com conto, a mesma coisa com prosa, a } \\
\text { mesma coisa com romance. Então meu objetivo era esse, que elas conseguissem } \\
\text { identificar as diferenças de todos esses formatos e que conseguissem criar } \\
\text { critérios próprios de avaliação de qualidade. Então a gente todo tempo fazia } \\
\text { isso, lia, buscava outros, discutia qualidade [...] Fiz debates em sala, fiz aulas } \\
\text { delas, por exemplo, Educação Infantil eu convidei uma pessoa que desse aula de } \\
\text { Educação Infantil e ela trouxe uma mala cheia de livros, Educação Infantil não, } \\
\text { Literatura Infantil, e aí depois a tarefa delas era dar aula para mim, e cada uma } \\
\text { tinha que dar aulas de um assunto diferente, embora elas tivessem assistido a } \\
\text { mesma aula, elas tinham que fazer aulas diferentes umas das outras [...] Vimos } \\
\text { curta-metragens e vimos longa-metragens. Assistimos vídeos de aulas, assistimos } \\
\text { palestras também nos vídeos. Usei a internet o tempo todo...." }\end{array}$ \\
\hline PE15 & $\begin{array}{l}\text { "A ideia de ir à livraria, CCBB, foi muito bem sucedida. Alguns alunos nunca } \\
\text { tinham ido a esses lugares e foi um mundo novo que se abria. Às vezes, o } \\
\text { professor se esquece de que não se vive só de regrinhas (...) Até mesmo porque } \\
\text { saber as regras gramaticais, apenas, não constrói um autor. Conheço fantásticos } \\
\text { professores de sintaxe que não conseguem escrever um texto claro e coeso. } \\
\text { Utilizei vídeos, músicas, fizemos passeio ao CCBB, Livraria da Travessa, } \\
\text { analisamos cores, imagens, sons, trabalhamos com a transcrição de falas... as } \\
\text { aulas era metade expositivas e metade práticas, oficinas de escrita e leitura. } \\
\text { Construiamos pequenos textos, frases, parágrafos em todas as aulas. } \\
\text { Trabalhamos com a correção entre pares, eles mesmos analisavam os textos dos } \\
\text { colegas e depois eu fazia uma leitura final... Havia espaço para falarem de } \\
\text { dúvidas, sugerirem coisas..." }\end{array}$ \\
\hline
\end{tabular}

Leta, nesse sentido, afirma: 
Se entendo que a escrita é uma prática social e cultural, suas experiências antecedem, sucedem e acompanham a trajetória escolar. Assim, a formação do leitor/escritor, passa, também, pelo acesso a centros culturais, bibliotecas, museus, teatros, cinemas, espetáculos musicais ou de dança (Kramer, 1997a), experiências que raramente são incluídas e propiciadas aos futuros professores nos cursos de formação (LETA, 2005, p. 82).

Para Cunha e Santos (2006), as dificuldades na escrita de estudantes referemse a falta de leitura e acesso a bens culturais:

Constata-se que, apesar do grande número de erros gramaticais e de construção lingüística encontrados normalmente nos textos produzidos por vestibulandos e universitários ingressantes, o problema real não pode ser debitado ao ensino da gramática, mas à falta de leitura e consequente falta de informação e de referenciais culturais, por parte dos estudantes. Vale destacar que os universitários, ao contrário dos leitores iniciantes, têm habilidades e estratégias que os ajudaram a entrar na universidade. Então, na prática, esses universitários necessitam de estratégias que os ajudem no desenvolvimento das suas capacidades lingüísticas. (CUNHA \& SANTOS, 2006, p.243).

Bechara (2006) acrescenta ainda que a tarefa de um professor de língua materna é promover o acesso do aluno a uma cultura integral, que se refere a uma ampliação de conhecimento de mundo. Aliás, tarefa esta de todo o professor, independente da área de atuação. Reconhece que a tarefa dos professores por si só já é complexa, mas que não por isso estão eximidos de proporcionar esse contato do aluno com o novo. Observe-se que esta prática é realizada no curso de formação de professores em questão através das disciplinas específicas aqui estudadas.

Todas as preocupações estão voltadas para a construção do conhecimento. Observe-se que, pelo depoimento dos professores, sua atuação foi basicamente nas bases de conhecimento acessadas na memória de longo prazo do aluno-escritor. Obviamente, com reflexos nas outras etapas, visto que as informações acessadas na memória alimentam o componente de tradução em um processo recursivo. No contexto da tarefa, por exemplo, observamos uma preocupação das alunas da turma 
da primeira disciplina optativa com os artigos acadêmicos e com a turma da segunda disciplina optativa com os blogs. Quer dizer, é perceptível a preocupação das estudantes com a importância da escrita real, social e acadêmica. Além disso, em ambas as turmas a revisão foi explorada pelos professores, no sentido de fazer o aluno reavaliar toda a sua escrita. Um processo recursivo, como explicado anteriormente, que faz com que o aluno retome todas as etapas do processamento, já que a revisão de um ponto do texto pode exigir uma nova busca de informação na memória de trabalho e a produção de novas estruturas, por exemplo.

Esse trabalho desenvolvido nas disciplinas optativas também produziu efeito sobre a etapa da tradução. Esse elemento pode ser verificado nas autoavaliações das alunas quanto a seus progressos. Todas as participantes da entrevista afirmam que constataram evoluções em sua escrita. A estudante 21PR, por exemplo, afirma que: "Houve progresso sim e, pelo menos no meu caso, eu tinha muitas dúvidas de como começar um texto, de como terminar, e eu acho que isso foi um grande diferencial". Verifique-se que, a partir da abordagem diferenciada do professor, a aluna conseguiu evoluir e perceber isso por si própria. Quando menciona que apresentava dúvidas sobre o processo de escrita como começar e terminar um texto, sem querer ela consegue expor um panorama da concentração de suas dificuldades iniciais.

A Estudante 17PB, nesse mesmo viés, sugere que o estímulo e ampliação dos conhecimentos foi crucial para o desempenho que ela avalia ter melhorado, principalmente devido ao fato do trabalho na disciplina ter sido iniciado a partir dos conhecimentos prévios que possuía: "[...] porque eu me considerava assim um desastre na escrita, e, pela maneira como ela foi fazendo avaliação, estimulando a gente a escrever partindo das nossas experiências pessoais do que a gente aprendia aqui, eu fui aprendendo a escrever. Hoje eu não vou dizer para você que eu sou uma escritora porque eu não escrevo com tanta frequência, mas eu consigo me sentir satisfeita com o que eu escrevo. Então assim, até em relação à autoestima, isso mudou”.Um outro momento no qual é possível estabelecer relações entre a atividade de escrita do aluno e o processamento cognitivo da escrita encontra-se na questão 17 do questionário dado. Nesta análise, foi possível incluir os três grupos de discentes 
(vinte e seis alunos) visto que foi uma questão integrante do questionário, no qual foram indagados sobre suas práticas durante a escrita de um texto. As respostas obtidas foram as seguintes:

Tabela 7. Ações que as estudantes realizam ao produzir um texto ${ }^{20}$

\begin{tabular}{|c|c|c|c|c|c|c|c|c|c|c|}
\hline \multirow{2}{*}{ Opção de resposta } & \multicolumn{2}{|c|}{ Nunca } & \multicolumn{2}{|c|}{ Raramente } & \multicolumn{2}{|c|}{ Às vezes } & \multicolumn{2}{|c|}{ Frequent. } & \multicolumn{2}{|c|}{ Sempre } \\
\hline & $\mathbf{F}$ & $\%$ & $\mathbf{F}$ & $\%$ & $\mathbf{F}$ & $\%$ & $\mathbf{F}$ & $\%$ & $\mathbf{F}$ & $\%$ \\
\hline Revisa $\quad$ seu & & & & & & & & & & \\
\hline $\begin{array}{l}\text { trabalho/texto antes de } \\
\text { entregar. }\end{array}$ & 0 & - & 0 & - & 3 & 12 & 10 & 38 & 13 & 50 \\
\hline $\begin{array}{l}\text { Solicita a um colega } \\
\text { para revisar seu texto }\end{array}$ & 2 & 7 & 9 & 35 & 9 & 35 & 5 & 19 & 1 & 4 \\
\hline $\begin{array}{l}\text { Precisa do auxílio de } \\
\text { alguma pessoa para } \\
\text { construir um texto. }\end{array}$ & 6 & 23 & 12 & 46 & 8 & 31 & 0 & - & 0 & - \\
\hline $\begin{array}{l}\text { Busca apoio para a } \\
\text { construção do texto em } \\
\text { sites da internet }\end{array}$ & 3 & 12 & 9 & 35 & 7 & 27 & 2 & 7 & 5 & 19 \\
\hline
\end{tabular}

A questão fez menção basicamente a dois aspectos importantes no processo de escrita: à revisão e à busca por apoio. As alunas declaram revisar seus textos ou trabalhos antes de entregá-los sempre (50\%) ou frequentemente (38\%). Não costumam solicitar a um colega que revise seu texto, pois isso só ocorre 'às vezes' ou 'raramente' em proporção semelhante: $35 \%$. Apenas uma aluna, que corresponde a 4\% do total de participantes, indica sempre necessitar do apoio de um colega. São 12 as alunas que afirmam raramente precisar de ajuda para construir um texto, 8 necessitam de ajuda às vezes e 6 nunca precisam de ajuda. As participantes não costumam buscar apoio em sites da internet para construção do texto: para três, $12 \%$, isso nunca ocorre; para nove, 35\%, ocorre raramente; para sete, $27 \%$, acontece às vezes. Apenas 7\% apontam recorrer a ajuda na internet frequentemente e 19\% afirmam que fazem isso sempre.

${ }^{20}$ Código para identificação: $\mathrm{F}=$ frequência 
A revisão é uma importante etapa do processo da escrita de um texto. Envolve momentos recursivos, a retomada de objetivos previamente traçados. É uma fase que permite ao escritor rever a coerência de sua proposta com seus resultados obtidos, não podendo ser considerada isoladamente como um momento separado de todo o desenvolvimento. Registre-se que apenas $50 \%$ das alunas afirmam sempre realizarem uma revisão antes de entregar um trabalho escrito a um professor. Considerando que esta é uma etapa crucial no modelo, a quantidade de alunos pode ser avaliada como relativamente baixa no que tange a uma preocupação com o texto revisado ${ }^{21}$.

Outro dado interessante diz respeito à necessidade de conhecimentos de que o grupo carece, se levarmos em conta que 53\% das participantes, com as respostas variando entre às vezes e sempre, indicam buscar apoio na internet para construir um texto. Resultado esse que sugere haver uma lacuna em relação à base da memória de longo prazo do escritor, conforme o modelo sugerido por Flower e Hayes (1980), podendo ser caracterizada como uma dificuldade em relação ao assunto.

Koch e Elias (2015) enfatizam que a escrita está estritamente relacionada à ativação de conhecimentos referentes à língua, ao conhecimento enciclopédico/de mundo, ao de texto e com práticas interacionais. O conhecimento linguístico refere-se ao conhecimento sobre gramática, ortografia e léxico, que foi adquirido ao longo da trajetória escolar e social de uma pessoa. O conhecimento enciclopédico, também conhecido como conhecimento de mundo, é uma área de nível mais particular e diz respeito a todo o conhecimento que um indivíduo tem sobre o mundo que o circunda. O conhecimento de textos está relacionado ao conhecimento das práticas comunicativas e seus respectivos conteúdos, estilos, funções e suportes. Está relacionado ao conhecimento de diferentes gêneros textuais. O último tipo de conhecimento é o interacional, que relaciona: a intenção da escrita, a explicitação dos objetivos do autor, a quantidade de informação necessária para a mensagem ser

21 O processo de revisão ocorre não somente ao final do texto, mas durante todo o processo de escritura. No questionário, contudo, o que foi enfatizado foi a revisão após a conclusão do texto, a revisão final. 
compreendida, a escolha da variante linguística a ser utilizada e a adequação do gênero textual. Esses conceitos também são partilhados por Kleiman (2004).

A Estudante 14, por exemplo, menciona que o docente da disciplina, ao proporcionar um maior contato do grupo de alunas com diferentes tipos de livros, promoveu o enriquecimento de vocabulário e estimulou a produção de textos de melhor qualidade. Observe-se que ocorreu um trabalho debruçado sobre o conhecimento linguístico e de textos dos alunos.

\subsection{Avaliação das disciplinas - entrevistas}

\subsubsection{Avaliação da disciplina optativa}

A questão 18 integrante do questionário dado às estudantes é o ponto de partida desta parte, tendo sido respondida obviamente apenas pelas inscritas na disciplina optativa mencionada, estando quatorze participantes habilitadas para respondê-la, de acordo com o quesito "estar cursando/ter cursado a disciplina optativa". A pergunta correspondia ao que motivou a inscrição em uma disciplina optativa. Entretanto, duas participantes optaram por não responder à questão. Esperava-se que as participantes elegessem apenas uma opção dentre as dadas. Porém, as marcações chegaram a até 3 por respondente. 
Quadro 16. Motivo da inscrição na disciplina optativa ${ }^{22}$

\begin{tabular}{|l|c|c|}
\hline \multicolumn{1}{|c|}{ Opção } & Frequência & Participante \\
\hline $\begin{array}{l}\text { Porque sinto necessidade de maior apoio para a } \\
\text { minha escrita. }\end{array}$ & 8 & $\begin{array}{c}\text { Estudantes 15PB, 16PB, } \\
\text { 22PB e 24M }\end{array}$ \\
\hline $\begin{array}{l}\text { Porque acredito na relevância do assunto para um } \\
\text { curso de formação de professores }\end{array}$ & 5 & $\begin{array}{c}\text { Estudantes 13PB, 15PB, } \\
17 \mathrm{~PB}, 20 \text { e 21PR }\end{array}$ \\
\hline Porque quero acompanhar um(a) colega. & 2 & Estudantes 14PB e 17PB \\
\hline $\begin{array}{l}\text { Porque a coordenação sugeriu minha inscrição na } \\
\text { disciplina. }\end{array}$ & 1 & Estudante 23PB \\
\hline Não responderam & 2 & Estudantes 25PB e 26M \\
\hline Porque um professor indicou a disciplina. & 0 & - \\
\hline Outro & 0 & $\mathbf{1 4}$ \\
\hline \multicolumn{1}{|c|}{ Total: respostas x alunas } & $\mathbf{1 8}$ & \\
\hline
\end{tabular}

De acordo com as estudantes, nenhum professor indicou a inscrição em tal disciplina. Apenas uma aluna inscreveu-se na disciplina por orientação da coordenação. Duas alunas fizeram-no para acompanhar outra colega, enquanto oito participantes declararam que perceberam necessidade de apoio e outras cinco acreditam na relevância da escrita para exercício da profissão.

A título de ilustração: a aluna que se inscreveu por orientação da coordenação é a Estudante 23PB, que possui formação exclusivamente em escolas públicas. No momento da entrevista, estava produzindo 2 tipos de material escrito: resenha e trabalho acadêmico. Estava escrevendo não apenas por uma exigência acadêmica, mas também para exercitar a própria escrita. Ela não se considera uma boa escritora e, além da escola, outros ambientes culturais contribuíram principalmente para a sua formação, sendo considerados mais importante que a família. Percebe a escrita como um dos aspectos mais importantes para exercer a profissão, afirmando ter o domínio da norma padrão dentro da média, apesar de ainda não se avaliar apta para atuar. Para ela, os docentes do curso são preparados para atuar na intervenção da escrita, porém

${ }^{22}$ As estudantes em negrito preferiram não participar da entrevista. 
não qualifica a grade curricular do curso de Pedagogia suficiente para apoiar alunos que necessitem de suporte, justificando: "Acredito que poderiam haver mais disciplinas de leitura e escrita, e de produção textual’'. A principal medida que poderia ser tomada para a estudante seria um acompanhamento individualizado com os professores.

As próprias estudantes deixaram transparecer a ideia que detinham sobre a escrita e sobre o curso - antes e após cursarem a disciplina optativa. No início, esperavam que fosse uma disciplina rígida, de caráter extremamente formal em relação à Língua Portuguesa. Porém, com o desenrolar do curso, suas percepções foram mudando, pois conseguiram encontrar na escrita uma atividade significativa e também prazerosa.

As estudantes que participaram da entrevista coletiva (Estudantes 13PB, 14PB, 17PB, 20, 22PB e 23PB) indicaram diferentes motivos para a inscrição na disciplina optativa, incluindo relevância e necessidade para a formação, acompanhamento de uma colega e como sugestão da Coordenação do Curso. Porém, é interessante notar que todas elas, durante a entrevista, explicitaram como a concepção delas foi ampliada.

As manifestações mais intrigantes na entrevista foram das estudantes 13PB, $14 \mathrm{~PB}$ e 17PB. A Estudante $13 \mathrm{~PB}$ atribui uma responsabilidade à professora ao afirmar: "eu acho também que a personalidade (do professor). Porque eu fiquei sabendo de outra professora que era uma questão técnica, de leitura e escrita mesmo, correção de gramática, ortografia, estrutura de texto, uma coisa de troca e leva do aluno. Tipo o aluno entrega o texto, o professor corrige, e o aluno refaz o texto para o professor corrigir novamente. E ela não, ela já não tem esse recurso, essa metodologia, ela já tem outra forma de lidar com essas questões da leitura e da escrita. Agora que ela pediu um trabalho de escrita assim, no final, porque até então era uma questão pessoal de cada um".

A Estudante 14PB completa essa percepção da aluna anterior e sustenta a importância do papel do professor nesse trabalho com a escrita: "porque (o professor) agrega. Você não faz só para cumprir currículo, você sai e sai com a satisfação de 
ter aprendido alguma coisa que é válida”. A Estudante 17PB declara que a disciplina foi além do que era esperado: "Não correspondeu às minhas expectativas não, foi além das minhas expectativas." Acrescenta ainda que: "Foi além do que eu esperava, porque essa disciplina era dada por outros professores. Então nós, os alunos, a gente sempre procura saber o que acontece naquela disciplina, qual a metodologia do professor. E então eu esperava uma disciplina muito mais técnica, e (o professor) foi além”. Essa percepção foi compartilhada igualmente por suas colegas.

E como será que as participantes avaliaram os professores das disciplinas optativas nos anos estudados? Como avaliaram a disciplina em si? Bem, todas as avaliações foram extremamente positivas, em ambos os aspectos. Os docentes foram avaliados como apaixonados, acessíveis, instigantes e que dominam o assunto. Vejamos algumas de suas falas:

\section{Quadro 17. Avaliação dos docentes das disciplinas específicas pelos alunos}

\begin{tabular}{|c|c|}
\hline Participante & Depoimento \\
\hline $\begin{array}{l}\text { Estudante } \\
\text { 21PR }\end{array}$ & $\begin{array}{l}\text { [...] completamente acessível, sempre presente, respondia e-mail, também no } \\
\text { facebook se precisasse falar alguma coisa... }\end{array}$ \\
\hline $\begin{array}{l}\text { Estudante } \\
\text { 14PB }\end{array}$ & $\begin{array}{l}\text { A maneira como ela conduz faz com que não seja uma coisa obrigatória } \\
\text { como nas outras disciplinas, eu tenho trabalho para entregar tal dia, eu fico } \\
\text { naquela tensão porque eu tenho que entregar aquele trabalho (...) essa } \\
\text { questão que a gente estava falando, de ela sentar com a gente e estudar com } \\
\text { a gente, torna as coisas mais naturais, então você faz com tranquilidade, até } \\
\text { porque se você está com alguma dificuldade em algum momento do texto, } \\
\text { ela se coloca à total disposição para sanar qualquer dúvida. }\end{array}$ \\
\hline $\begin{array}{l}\text { Estudante } \\
\text { 17PB }\end{array}$ & $\begin{array}{l}\text { E sem contar os autores, ela falava sobre os autores com muita propriedade, } \\
\text { ela falava sobre os livros com muita propriedade, sobre os diferentes tipos } \\
\text { de gêneros textuais com muita propriedade, 'não, esse gênero aqui quem } \\
\text { escreve é o fulano de tal e ele tem uma maneira de escrever assim'. Então } \\
\text { assim, ela fala com muita propriedade, você percebe que ela sabe do que } \\
\text { está falando, e ela não está falando asneira, e que não é uma coisa que o } \\
\text { professor estudou para falar aqui, ela realmente sabe do que está falando. }\end{array}$ \\
\hline
\end{tabular}

Ainda sobre a avaliação da disciplina optativa, as alunas também apresentam depoimentos similares. Para elas, foi um curso tranquilo, produtivo, enriquecedor, flexível, que superou suas expectativas. A manifestação da Estudante 13PB nos leva a entender que em algumas disciplinas, os alunos comparecem apenas para "não 
ganharem falta”. Atente-se também para todas as outras falas, que revelam uma ideia inicial da disciplina, de sua organização, e a subsequente substituição das ideias.

\section{Quadro 18. Avaliação da disciplina optativa pelas alunas}

\begin{tabular}{|c|l|}
\hline Participante & \multicolumn{1}{|c|}{ Depoimento } \\
\hline $\begin{array}{c}\text { Estudante } \\
\text { 13PB }\end{array}$ & $\begin{array}{l}\text { Toda aula você sai com essa sensação, tipo eu fiz alguma coisa, não fui só para } \\
\text { a aula para não ganhar falta. }\end{array}$ \\
\hline $\begin{array}{c}\text { Estudante } \\
\text { 14PB }\end{array}$ & $\begin{array}{l}\text { [...] porque ela agrega, você não faz só para cumprir currículo, você sai e sai } \\
\text { com a satisfação de ter aprendido alguma coisa que é válida. }\end{array}$ \\
\hline $\begin{array}{c}\text { Estudante } \\
\text { 17PB }\end{array}$ & $\begin{array}{l}\text { expectativas. Foi além do que eu esperava, porque essa disciplina era dada por } \\
\text { outros professores. Então nós, os alunos, a gente sempre procura saber o que } \\
\text { acontece naquela disciplina, qual a metodologia do professor. E então eu } \\
\text { esperava uma disciplina muito mais técnica, e ela foi além. }\end{array}$ \\
\hline $\begin{array}{c}\text { Estudante 20 } \\
\text { [...] muito flexível. A questão do horário, que a gente chegou pensando que ia } \\
\text { ser bem pesado quatro horas, aí a gente organizou o horário de intervalo. E } \\
\text { fazer os trabalhos em sala eu acho que isso ajuda muito porque a gente já está } \\
\text { ali, a nossa concentração já está ali. }\end{array}$ \\
\hline $\begin{array}{l}\text { Estudante } \\
\text { 23PB }\end{array}$ & $\begin{array}{l}\text { E todo mundo achou que fosse ficar muito cansativo, que não fosse gostar } \\
\text { acompanhar, acho que foi bem tranquilo. }\end{array}$ \\
\hline
\end{tabular}

De modo geral, é possível listar alguns aspectos que as alunas aprenderam na disciplina e que manifestaram como relevante salientar durante a entrevista:

1. Aspectos gramaticais e de produção de texto;

2. Diferentes gêneros textuais; e

3. Trabalhar reescrita.

Além disso, as alunas ainda sugerem que descobriram o prazer na escrita e o gosto pela leitura, atividades anteriormente vistas como não prazerosas. Após cursarem a disciplina, elas avaliam que houve progresso na escrita e que agora têm o cuidado para escrever tranquila e qualitativamente. A Estudante 20 diz que a disciplina "[...] fez muita diferença. Eu acho que hoje eu escrevo com muito mais tranquilidade do que quando eu escrevia lá no início. Também porque a carga de 
escrita, a demanda, é muito grande, então a gente acaba meio que se habituando, mas depois da disciplina eu me senti muito mais segura para escrever". A Estudante 21PR afirma que "houve progresso sim e, pelo menos no meu caso, eu tinha muitas dúvidas de como começar um texto, de como terminar, e eu acho que isso foi um grande diferencial'.

A Estudante 14PB, por sua vez, elabora uma relação entre leitura e escrita: "porque a leitura acadêmica ela não é uma leitura propriamente dita, na maioria das vezes eu caço as palavras-chave no texto, não tenho tempo para ler todos os textos. Então eu pego ali, busco a ideia central, e vou para a aula. E agora não, ela conseguiu fazer com que o livro nos prendesse, e com isso você vai enriquecendo seu vocabulário e conseguindo produzir textos de maior qualidade".

Quando os professores das optativas são indagados sobre a necessidade ou não da disciplina, aparentemente os docentes consideram que a mesma é relevante para o Curso, mas não defendem a sua obrigatoriedade, alegando que é necessário um maior acompanhamento inicial com os alunos e também um maior período de duração dos estudos. Foram os docentes PE13 e PE15 que avaliaram esse quesito. Enquanto o primeiro afirma que a disciplina deve continuar como optativa, porém com um maior suporte dos professores do curso, que precisam acompanhar os alunos e perceber a necessidade ou não dos mesmos cursarem tal disciplina, o segundo não apresenta uma pré-concepção sobre a obrigatoriedade ou não da disciplina optativa e acredita que o trabalho coletivo dos professores, incentivando os discentes que necessitem de apoio a inscreverem-se na disciplina, pode auxiliar esse processo. Observe que ambos os participantes acreditam na capacidade intervencionista dos docentes do curso para indicar os alunos para cursarem a disciplina optativa.

As alunas, por outro lado, expõem uma posição diferente. Para elas, a disciplina optativa deveria se tornar obrigatória. Declaram vários motivos, dentre os quais seleciono aqui: a defasagem que mencionam possuir em relação ao domínio da língua e o encantamento que a disciplina proporciona. Vejamos: 
Quadro 19. Avaliação das alunas da necessidade da disciplina optativa

\begin{tabular}{|c|c|}
\hline Participante & Depoimento \\
\hline Estudante 20 & [...] acho que devia ser parte da grade, das obrigatórias. \\
\hline Estudante 21PR & $\begin{array}{l}\text { Como obrigatória, porque a gente chega com uma defasagem muito grande. E } \\
\text { eu acho que isso é geral. A gente não sabe escrever um artigo acadêmico. E } \\
\text { isso é uma das grandes dificuldades que a gente encontra na faculdade. } \\
\text { "Socorro, como eu vou escrever isso?". E o professor fala 'vai lá, entra no } \\
\text { site, vê a norma tal e vocêfaz de acordo com aquilo', só que ele não ensina a } \\
\text { usar a ferramenta da maneira certa. Eu acho que poderia ser mais de uma } \\
\text { disciplina. }\end{array}$ \\
\hline Estudante 23PB & Ou então 'I' e 'II', uma sequência. \\
\hline Estudante 13PB & $\begin{array}{l}\text { eu acho que ela deveria ser obrigatória. E ela poderia ser até uma matéria de } \\
\text { primeiro periodo, até para encantar os alunos a continuar no curso, porque } \\
\text { as primeiras disciplinas são tão maçantes que as pessoas abandonam. }\end{array}$ \\
\hline Estudante 17PB & $\begin{array}{l}\text { Essa disciplina, para a Pedagogia, deveria ser obrigatória como a Estudante } \\
13 \text { falou, primeiro porque ela começa a despertar a importância da cultura, } \\
\text { ela amplia seu vocabulário, ela amplia a sua sensibilidade estética, ela } \\
\text { amplia sua compreensão sobre cultura, ela traz um mundo novo, ela faz você } \\
\text { compreender o que é cultura, porque muita gente que faz Pedagogia não tem } \\
\text { muito acesso, tô sendo muito... discriminando, mas a verdade é essa. O } \\
\text { próprio curso não te permite ter acesso. Então essa disciplina de leitura e } \\
\text { escrita te possibilita isso. (...) Hoje eu sei te dizer, hoje eu sei, não conheço } \\
\text { profundamente, mas eu sei identificar, eu sei compreender, eu sei iniciar e } \\
\text { terminar uma leitura, interpretar, e tudo isso é muito importante, e não só na } \\
\text { disciplina de Pedagogia, mas no que diz respeito também à cultura. Teve a } \\
\text { questão da adaptação literária, que isso trouxe um outro olhar sobre cinema, } \\
\text { sobre teatro, sobre diversos aspetos da cultura, não só a leitura nos livros. }\end{array}$ \\
\hline
\end{tabular}

A partir das avaliações da relevância da disciplina optativa, questionamos os professores das disciplinas optativas sobre as percepções de progresso dos alunos. Ambos declararam ter percebido progresso. Enquanto PE13 reforça a influência positiva que a ampliação de repertório cultural teve no desenvolvimento da turma, PE15 relata a evolução claramente perceptível nas produções escritas do grupo:

Quadro 20. Percepção de progressos nas alunas das turmas das disciplinas optativas

(continua)

\begin{tabular}{|l|l|}
\hline Participante & \multicolumn{1}{c|}{ Depoimento } \\
\hline \multirow{5}{*}{ PE13 } & Percebi, mas a gente sempre quer ver mudanças, professor sempre quer achar que \\
& ele teve algum impacto. É tão difícil ler isso pelos meus olhos, mas percebi. \\
& Primeiro porque esse era um tema com o qual elas jamais tinham lidado: \\
& literatura, gêneros literários, quem são os clássicos, quem são os principais \\
& autores da história da literatura mundial, o que é literatura inglesa, o que seria a \\
& literatura brasileira, que é um clássico da literatura, quais são os critérios que \\
& você usa para analisar um romance, esse era um tema que elas jamais tinham \\
& tratado, e elas estão no último período, a maioria delas está se formando. Então eu \\
& percebi, percebi nesse sentido. Eu acho que no trabalho da gente a gente meio que \\
\hline
\end{tabular}




\begin{tabular}{|c|c|}
\hline & $\begin{array}{l}\text { oferece lente para a pessoa ler a realidade, essa lente não tinha ainda sido } \\
\text { proposta para elas, que não é uma lente que eu resolvi dar, é uma lente que a } \\
\text { disciplina propõe. Elas não tinham feito essa disciplina antes. O que eu quero } \\
\text { dizer é que assim, não é apenas uma questão de escrita acadêmica, é uma questão } \\
\text { de compreensão do papel social da escrita, papel social do texto escrito, papel } \\
\text { social da literatura, papel social de uma arte ancorada na escrita, isso não era } \\
\text { uma questão para elas, nem passou pela cabeça delas que tem um papel social, e o } \\
\text { que significa, socialmente a gente discutiu, é cuidar do curso todo, o que significa } \\
\text { socialmente alguém que não tem esse repertório, que passou a vida inteira sem ter } \\
\text { esse repertório [...] }\end{array}$ \\
\hline PE15 & $\begin{array}{l}\text { Sim. Houve progresso, se considerarmos o breve período de curso [...] e a gama } \\
\text { de informaçóes oferecidas neste periodo. Vi muitos textos truncados, agarrados em } \\
\text { vícios no inicio. No fim do período vi textos mais leves, com estilos próprios. Vi } \\
\text { textos mais encadeados, com ideias melhor organizadas. Houve mais cuidado com } \\
\text { os textos finais. Os alunos entenderam que deveriam trabalhar nos próprios textos. } \\
\text { Isso é um exemplo importantíssimo! }\end{array}$ \\
\hline
\end{tabular}

(conclusão)

É interessante observar nos depoimentos desses professores que a percepção de progressos em seus trabalhos ocorreu em dois aspectos distintos, porém complementares, para cada um. Enquanto PE13 sugere maior foco no trabalho com a leitura e consequentemente percebe maior desenvolvimento das estudantes nesse aspecto, PE15 ressalta a escrita e relata que foi possível acompanhar durante a disciplina uma evolução na qualidade dos textos produzidos pela turma.

\subsubsection{Avaliação da disciplina obrigatória}

Por ser uma disciplina obrigatória do primeiro período do Curso de Pedagogia, pressupõe-se que todos os calouros iniciam o curso inscritos nela.

Foram no total 12 respondentes no questionário e 11 na entrevista. A única aluna que não participou da entrevista foi a Estudante 11M.

Quando as alunas, ao final do semestre, foram solicitadas a refletir sobre todo o trajeto percorrido durante o período, foi possível perceber em suas falas que caracterizaram a disciplina como difícil e cansativa (Estudantes 4PR, 5M, 6PR, 11M). 
Acreditamos que tal postura pode vir do fato de o grupo estar iniciando a graduação e ainda não estar plenamente adaptado à rotina acadêmica.

Ainda assim, apesar de tais dificuldades, as estudantes $5 \mathrm{M}$ e $6 \mathrm{PR}$ relataram que a disciplina fora proveitosa e o modo pelo qual a docente lecionava cativou a todos, pois capacitava os alunos a fazerem suas escolhas sobre temas que gostariam de focalizar em trabalhos, por exemplo. Nesse sentido, o professor da turma é avaliado pelo grupo como: bom, atencioso, detalhista e dinâmico.

As alunas também foram questionadas sobre o que aprenderam com a disciplina obrigatória e listaram, todas em comum acordo, os seguintes aspectos:

1. Resumo;

2. Mapa conceitual;

3. Coerência e coesão;

4. Apresentações; e

5. Ortografia.

É interessante observar que as alunas explicam que conseguiram realizar treinamentos de apresentações e a Estudante 6PR ressalta a importância disso: “ $A$ gente vai apresentar agora nas últimas aulas um trabalho e eu acho que isso é muito legal também, treinar apresentação, porque nós não estamos acostumados com isso".

Em relação à ortografia, o grupo também explica como funcionava o trabalho em torno do assunto. A Estudante 10PB ressalta a complexidade do assunto: “[...] ortografia não dá pra ser em uma aula. Ia ter que dedicar um mês, porque é muito abrangente. Ortografia é mais rever nossos erros do que ensinar". Nesse mesmo sentido, a Estudante 6PR reforça essa percepção: "Não foi uma aula específica, mas eu também não acho que deveria ser".

O docente dessa disciplina obrigatória também foi questionado sobre como percebe o progresso das alunas e declarou que consegue sim perceber progressos da seguinte forma: “Consigo, não vou dizer com todos, mas aí que eu digo, eu comparo a primeira (redação), [...] como é que ele chegou aqui na minha mão, e esta redação 
eu guardo e leio no final do curso, nós fazemos isso, não é privilégio meu não, é a metodologia do nosso grupo. Aí nós vamos ler. Eles dizem, eles próprios têm, que é o mais importante ele ser revisor do texto dele, esse é outro ponto que a gente busca alcançar, não vai ter ninguém corrigindo seu texto o tempo todo, já acabou esse negócio, então você precisa ter um distanciamento crítico, voltar ao seu texto, deixa ele descansar, volta lá e você mesmo vai ver, o próprio aluno. Então eles falam assim 'nossa, isso aqui estava horrivel mesmo!'. Esse ai é o melhor momento, quando a gente conseguiu que o próprio produtor do texto faça uma avaliação da produção dele. Uns demoram mais, uns eu sei que não vão melhorar, que vão passar com seus 5, seus 6, só vão melhorar lá na frente, que ainda precisariam de mais tempo, de mais reescrituras, não dá para fazer tantas".

Observe-se que o professor trabalha com a seguinte metodologia: no início do semestre, solicita uma redação sobre algum tema relevante em questão. Ao final do curso, os alunos produzem um texto final, e realizam uma comparação entre ambos. Muitos, por si próprios, conseguem perceber suas evoluções. O professor da turma trabalha, nesse sentido, no desenvolvimento da capacidade de revisão pelo próprio aluno.

\subsubsection{Avaliação das disciplinas específicas pelos docentes}

Analisadas as avaliações dos estudantes quanto à 'qualidade' dos cursos, interessa-nos também saber quais são suas propostas iniciais, através de suas ementas, e quais são os objetivos de trabalho dos professores.

Observe que existe uma diferença importante entre as disciplinas. A obrigatória tem como foco a produção já de determinados gêneros textuais, pressupondo um certo domínio de habilidades de escrita por parte do aluno. Difere da disciplina optativa, que não tem como meta desenvolver o gosto pela leitura e para a qual não está previsto o trabalho com gêneros literários. Estão sendo comparadas disciplinas com escopos e objetivos distintos. 
Durante as entrevistas, os docentes foram indagados sobre seus objetivos com a disciplina. Vejamos agora quais foram suas atuações e em qual sentido elas foram conduzidas. Para PE14, professor da disciplina obrigatória, seu objetivo era: "dar ferramentas, conscientizar, principalmente, conscientizar esses alunos que dentro da universidade ele precisa lidar, trabalhar, produzir, ler gêneros textuais que não são, obrigatoriamente também não são, mas que não são trabalhados pela escola no ensino médio. Então o objetivo é que ele reconheça a necessidade de ler artigos, de escrever de acordo com o gênero acadêmico, uma linguagem cuidada, de ser fiel às referências, eles precisam aprender a fazer citações, fichamento. O objetivo é fazer com que ele caminhe, a partir do curso, pelas outras disciplinas de uma maneira mais acadêmica possível no que tange à questão textual, tanto oral quanto escrita".

PE14 afirma que trabalha com diferentes gêneros textuais e que o aluno precisa conhecer o gênero acadêmico, que, de acordo com o mesmo, consiste basicamente na linguagem que é utilizada na academia, tanto na modalidade oral quanto na modalidade escrita. Além disso, PE14 reconhece que sua disciplina é porto de entrada para uma passagem segura pelas demais, visto que trabalha com a escrita acadêmica.

O professor da disciplina optativa PE15 é bastante abrangente e cita como objetivos a necessidade de fazer o aluno perceber a gramática como manual, o desenvolvimento da autoria, conhecer diferentes gêneros textuais, desenvolver o gosto pela leitura etc. De acordo com suas próprias palavras, PE15 intencionou "dar a a aluno possibilidades de ler textos variados e, a partir deles, construir um espaço para a expressão de ideias. Como meta, queríamos que os alunos pudessem ler, gostar da leitura, adquirir intimidade com essa atividade vendo nela prazer e, paralelamente, desejávamos que a escrita fosse praticada de modo livre, mas com qualidade [...] além de trabalhar a desinibição da escrita, partindo do que eles (alunos) queriam com o curso, apresentamos diversos gêneros do discurso, técnicas de fichamento, resumo e resenha, regras de acentuação, mas nada que tivessem que memorizar. A gramática foi apresentada a eles como um manual que deve ser consultado sempre que houver dúvidas, assim como o dicionário. Os alunos precisam 
ter conhecimento das múltiplas ferramentas que podem auxiliá-los na melhoria de seus textos. Basicamente o comando era: escreva sem medo”.

Já o docente da outra disciplina optativa, PE13, teve como objetivo ampliação do repertório literário dos alunos e a compreensão das diferentes linguagens, através do conhecimento de diferentes gêneros textuais. Entretanto, diferentemente de PE15, PE13 focalizou em aspectos literários: "elas (as alunas) precisam ampliar o repertório literário [...] ter uma compreensão melhor dos gêneros literários e dos diferentes modos de escrita associados a cada gênero".

Observe que as disciplinas optativas permitiram aos professores autonomia para desenvolver diferentes perspectivas e ambas satisfatórias. Como as disciplinas optativas estudadas neste trabalho apresentam caráter inovador em relação ao currículo da instituição, considerou-se necessário qualificar as experiências dos docentes que as ministram. . Além disso, apesar de não existir a mesma possibilidade de comparar diferentes turmas da obrigatória, também é interessante perceber a avaliação que o docente da disciplina faz sobre a mesma e sobre a sua atuação enquanto professor.

Para PE13, da optativa, ministrar por um período a disciplina foi considerada uma atividade maravilhosa, visto que conseguiu colocar em prática várias "coisas" que pensava e que nunca tinha tido a oportunidade, como por exemplo ampliar o acesso de um aluno a textos literários de grande relevância para a sociedade brasileira.

PE15, professor da disciplina optativa, também menciona essa 'liberdade', enfatizando também a satisfação com os frutos de seu trabalho manifestados nos desempenhos elevados dos discentes: "Sempre acho que poderia ter sido melhor, ou que outras técnicas poderiam ter sido usadas. No entanto, acho que receber uma turma que lia e escrevia muito pouco e no final do curso ter alunos leitores escrevendo um pequeno artigo acadêmico... isso me leva a crer que a experiência foi exitosa. O curso foi diferente de outros que já existem. Tive liberdade para criar as aulas, decidir o que lecionaria, de acordo com a demanda dos alunos e de suas reais necessidades". 
PE1 informa que percebe suas próprias evoluções ao longo de sua trajetória profissional e avalia que o maior desafio para o curso de Pedagogia é ter um programa a ser cumprido, como em qualquer outra área, e depara-se com dificuldades inesperadas, que necessitam de maior intervenção. Questiona: "Como ensinar resenha, resumo, referências bibliográficas pela ABNT para quem ainda tem problemas básicos na linguagem, na língua escrita e na língua falada?". O docente indica realizar um trabalho no qual retoma constantemente as dúvidas dos alunos e que, por isso, devido à complexidade da tarefa, seriam necessários mais períodos de atividade letiva para suprir as necessidades demandadas.

Fiad (2011) registra que existem conflitos entre as produções dos alunos e o que os professores esperam desses alunos, e que de modo geral existe a prática do mistério nas universidades, visto que muitas convenções da escrita são tidas como já conhecidas e acabam não sendo trabalhadas nas faculdades pelos professores. Eis que surge, assim, um questionamento: De onde partir? Como avaliar o que é conhecido? Quando ensinar o que não é conhecido? É possível avançar para atividades com níveis de complexidade maior, quando o básico é dificultoso?

\subsection{Nivelamento de Português}

Discutir sobre iniciativas de nivelamento não era o foco deste trabalho. Porém, o tópico apareceu no depoimento de alguns professores de forma bastante interessante e, a partir daí, tornou-se necessário problematizar o assunto.

$\mathrm{Na}$ universidade, o nivelamento em português tornou-se obrigatório para alunos ingressantes no Curso de Pedagogia a partir de 2015. O nivelamento é uma prova cuja aprovação é obrigatória para que o aluno possa se formar na universidade, em qualquer curso.

O foco da prova de nivelamento é a proficiência em Língua Portuguesa através de dois eixos: produção e compreensão de textos. Com relação à escrita, a 
prova requer conhecimentos que se adequem ao espaço acadêmico, incluindo os aspectos da coesão, coerência, progressão temática e informatividade. Já a leitura requer habilidades de reconhecimento de informações, de diferentes tipos de textos e linguagens, além de explorar a capacidade de avaliação crítica do leitor.

$\mathrm{Na}$ entrevista realizada com docentes e discentes, apenas o primeiro grupo se manifestou sobre o assunto. Foram três participantes que deram suas relevantes opiniões, sem ao menos serem questionados sobre o assunto: P4, P5 e P9. Enquanto o primeiro defende a prova de nivelamento, mas ampliando sua abrangência para todas as áreas do conhecimento e o segundo afirma que é um aspecto importante para a formação, o terceiro afirma que o nivelamento é desnecessário, principalmente devido a seu caráter “cerceador”. Observemos suas falas:

\section{Quadro 21. Opinião dos docentes sobre a prova de nivelamento}

\begin{tabular}{|c|c|}
\hline Docente & Depoimento \\
\hline P4 & 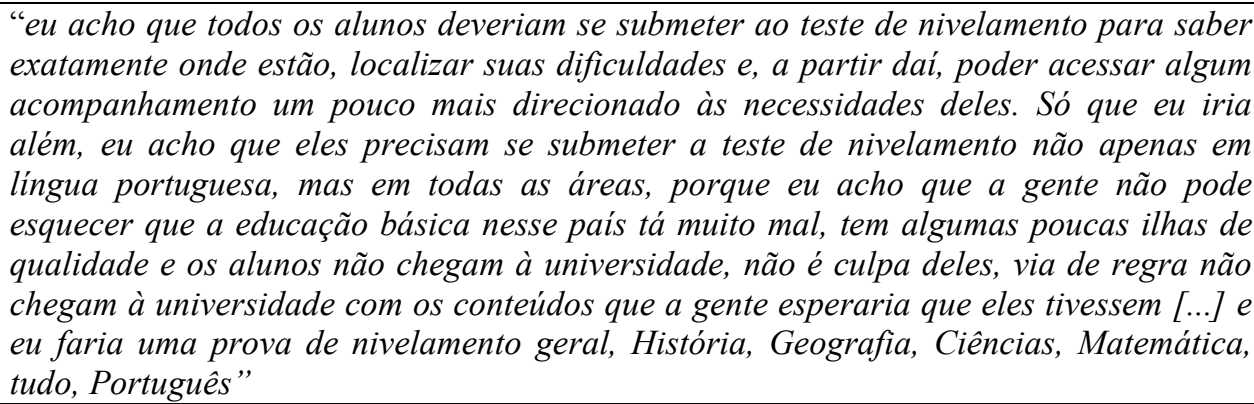 \\
\hline P5 & $\begin{array}{l}\text { "Exigir efetivamente dos alunos um preparo para esse nivelamento, porque muitos são } \\
\text { reprovados. São reprovados porque não sabem escrever um texto com início, meio e fim } \\
\text { [...]. Os alunos de pedagogia muitas e muitas vezes são reprovados, assim como outros, } \\
\text { eu tô falando de pedagogia porque é o departamento da tua pesquisa. Então eu acho que } \\
\text { esse nivelamento deveria ser exigido sim." }\end{array}$ \\
\hline P9 & $\begin{array}{l}\text { "A gente já conversou aqui várias vezes no Departamento a dificuldade de escrita dos } \\
\text { alunos e [...] éramos contra o nivelamento de Português. E nós argumentamos, eu } \\
\text { inclusive fui defensor dessa postura, que não é uma questão de uma prova, é uma } \\
\text { questão processual, não interessa como meu aluno chegou, interessa como ele vai sair. } \\
\text { Então houve um compromisso do Departamento de fazer um processo com os alunos, } \\
\text { que não delegasse isso só a uma prova de nivelamento, se sabe ou se não sabe escrever } \\
\text { bem [...] Então eu acho que ajuda sim, mas defendemos que essa postura deveria ser } \\
\text { uma coisa processual e não uma coisa de mais uma prova, porque a inclusive a prova } \\
\text { prende o aluno [...] Então a prova também poderia ter esse caráter, de você fazer para } \\
\text { você saber o seu nível, e não para te prender, eu sempre falei façam a prova para } \\
\text { conhecer o seu nível”." }\end{array}$ \\
\hline
\end{tabular}


Não há muita literatura relativa a iniciativas de nivelamento em universidades no Brasil, principalmente no tocante aos cursos de Pedagogia. Sacramento e Sobral (2013) realizaram um estudo exploratório com cursos de nivelamento com estudantes das áreas de Administração e Ciências Contábeis em uma Instituição de Ensino Superior na Bahia, com nome não divulgado. Para as autoras:

[...] os programas de nivelamento em pelo menos duas áreas do conhecimento, Matemática e Língua Portuguesa, ganham relevância, sobretudo porquanto o domínio básico nessas áreas é considerado como pré-requisito necessário para que o processo de ensino-aprendizagem do ensino superior seja desenvolvido de forma satisfatória. (SACRAMENTO \& SOBRAL, 2013, p. 1)

Sugerem, ainda, que a função de um curso de nivelamento é justamente suprir carências advindas da escolarização anterior de uma pessoa. Entretanto, a pesquisa revelou que $96,8 \%$ dos estudantes pesquisados não estavam inscritos e não frequentavam o curso de nivelamento em Português e 92\% em Matemática, indicando a falta de eficácia da instituição em questão ao oferecer o projeto. Soma-se a isso o fato de que $51,9 \%$ e $33,3 \%$ dos estudantes não tinham sequer qualquer conhecimento sobre a oferta das atividades.

É oportuno registrar que Sacramento e Sobral (2013) não sugerem como ocorre de fato essa iniciativa. Entretanto, esclarecem a todo tempo, implicitamente, que não se trata apenas de uma prova, de um momento estanque de avaliação. Ao contrário, em todo seu depoimento é perceptível que a iniciativa de nivelamento ocorre como um curso, no qual os alunos participam de um projeto. Não esclarecem, porém, resultados do processo.

Kretschmann, Conceição e Minuzzi (2013) apresentaram um esboço dos resultados de uma iniciativa de acompanhamento com alunos do curso de Direito do Cesuca, que focalizou aspectos gramaticais e textuais da Língua. O programa foi realizado em dois módulos: o primeiro funcional, destinado principalmente aos ingressantes, e o segundo tradicional, para pessoas com dificuldades normativas. 
Compreendem que "é necessário entender primeiro a função dos termos para depois nominá-los” (KRETSCHMANN, CONCEIÇÃO \& MINUZZI, 2013, p.6). Acrescentam ainda que essa é uma etapa necessária no curso de graduação em questão, devido às falhas da escolarização anterior:

\begin{abstract}
Se, desde as séries iniciais do ensino de nosso idioma, fosse possível desenvolver as habilidades de leitura e produção escrita de seus alunos, com ênfase nas relações funcionais dos elementos que compõem um texto, a sua capacitação para o exercício de ler e escrever certamente os alçaria paulatinamente para voos reflexivos sobre a linguagem. Chegariam na universidade sem necessitar de estudos adicionais e com isso avançar de forma mais célere o seu conhecimento. (KRETSCHMANN, CONCEIÇÃO \& MINUZZI, 2013, p. 3).
\end{abstract}

As dificuldades relacionadas à leitura e produção de textos são destacadas por Sampaio e Santos (2002) como aspectos mais impressionantes nos alunos ingressos em cursos de graduação da área de Negócios, em uma universidade privada em São Paulo. Os pesquisadores realizaram um estudo experimental durante quinze semanas, o equivalente a um semestre letivo, com quarenta e dois alunos dos períodos iniciais do curso. O projeto consistia nas seguintes etapas: apresentar um texto e solicitar aos alunos a identificação daquele tipo de texto e realizar a leitura dos textos escolhidos com base em uma leitura e análise críticas. Primeiramente, o professor explicava um passo-a-passo da análise que eles deveriam fazer e, em seguida, os alunos tinham que produzir alguma tarefa sobre o que tinha sido trabalhado. Os blocos de atividades eram divididos em unidades com duração de duas horas-aula por semana. Ao final de cada bloco, as correções eram individuais ou em grupo, tudo sendo realizado pelos próprios alunos com apoio do professor. Os próprios alunos eram capazes de avaliar e fazer considerações sobre os resultados dos colegas.

Entretanto, Sampaio e Santos (2002) afirmam que não ocorreram mudanças quantitativamente significativas. Conseguiram constatar que "enquanto as técnicas de leitura eram exercitadas com certa facilidade, as atividades de redação eram demoradas, com resultados, em geral, insatisfatórios" (SAMPAIO \& SANTOS, 2002, 
p. 36). Perceberam uma maior conscientização dos alunos sobre a importância da leitura e da escrita, maior percepção dos alunos quanto às suas próprias dificuldades e possibilidades de resolvê-las e aprimoramento do gosto pela leitura. De forma qualitativa, observaram que alguns desempenhos individuais foram melhorados, porém, as autoras não podem afirmar se tal fato foi devido ao programa ou a outro fator. Sampaio e Santos (2002) objetivaram verificar a viabilidade de um programa de intervenção de leitura e escrita com estudantes universitários. Porém, com o surgimento de algumas variáveis não esperadas, como a rotina cansativa dos alunos, o projeto teve uma realização lenta. Ainda assim, afirmam que:

[...] apesar do reconhecimento de que a aplicação de programas remediativos em sala de aula pode ser mais difícil do que em situações controladas, reitera-se aqui a crença de que tais programas são viáveis como parte de disciplinas regulares e que podem ser melhor explorados por professores de diversas disciplinas. (SAMPAIO e SANTOS, 2002, p. 36).

A instituição estudada nesta pesquisa, apesar de ter apenas uma prova de nivelamento, funciona em colaboração com outros núcleos do espaço universitário que têm como objetivo desenvolver habilidade de leitura e escrita junto a estudantes que precisam de apoio. Os referenciais teóricos apresentados nesta seção justamente corroboram a ideia de um projeto em curso e a longo prazo. Um verdadeiro processo de aprendizagem. Tem-se, do mesmo modo, a consciência de que um projeto de nivelamento não solucionará todas as dificuldades dos alunos, mas certamente é uma rota que precisa ser traçada como possibilidade.

\subsection{Análise da grade curricular}

Nesta seção, busco apontar como as alunas e professores avaliam a grade curricular do Curso de Pedagogia em questão. 
Os grupos foram indagados no questionário e na entrevista, respectivamente, com as seguintes perguntas:

$\checkmark$ para os alunos: Você considera que o atual currículo do curso de Pedagogia (distribuição das disciplinas e cursos oferecidos) é suficiente para auxiliar alunos que possuem dificuldades na escrita?

$\checkmark$ para os professores: Você acredita que essa disciplina (optativa) que você leciona é necessária? Por quê? Um semestre é suficiente para auxiliar os alunos? Ou você acredita que a duração deveria ser maior? Você acredita que ela deveria ser incorporada à grade curricular obrigatória?; Ao observar a grade curricular do Curso de Pedagogia (a atual e a antiga - ambas vigentes), você acredita que a atual distribuição de disciplinas é suficiente para auxiliar os alunos que demandam apoio nas atividades de escrita?; Quais medidas/trabalhos você poderia propor para que o curso complementasse (caso seja insuficiente) ou incrementasse (caso considere o currículo plenamente positivo) a área de produção escrita?

As respostas para tais questionamentos também serão desdobradas conforme o grupo de respondentes.

\subsubsection{Perspectiva dos discentes}

Foi possível dividir o grupo de estudantes em três grandes blocos: o das que consideram o currículo de Pedagogia suficiente para ajudar alunos que necessitam de apoio, outro das que consideram o currículo insuficiente e ainda o das que não responderam à questão. Estes resultados estão ilustrados no quadro abaixo: 
Quadro 22. Distribuição das estudantes para avaliação da grade curricular

\begin{tabular}{|c|c|c|}
\hline Grade Suficiente & $\begin{array}{c}\text { Grade } \\
\text { Insuficiente }\end{array}$ & Não responderam \\
\hline & Estudante 2PB & \\
Estudante 7PB & \\
Estudante 13PB & \\
Estudante 1M & Estudante 14PB & \\
Estudante 3PR & Estudante 15PB & \\
Estudante 4PR & Estudante 16PB & \\
Estudante 5M & Estudante 17PB & Estudante 9M \\
Estudante 6PR & Estudante 18M & Estudante 26M \\
Estudante 8PR & Estudante 19PB & \\
Estudante 10PB & Estudante 20 & \\
Estudante 11M & Estudante 21PR & \\
Estudante 12PR & Estudante 22PB & \\
& Estudante 23PB & \\
& Estudante 24M & \\
& Estudante 25PB & \\
& \\
\hline
\end{tabular}

As Estudantes 9M e 26M não responderam à questão sobre a qualificação da grade curricular.

Observemos o perfil das alunas que consideram o currículo do curso de pedagogia insuficiente: 11 são de formação exclusivamente em escolas públicas, 2 de formação mista, 1 de formação exclusivamente em escolas privadas.

Atente que 11 estudantes de formação exclusivamente em escolas públicas consideram o currículo do Curso de Pedagogia insuficiente para ajudar quem precisa de apoio. No total, 58\%, ou seja, quinze alunas, fazem a mesma avaliação. A estudante $21 \mathrm{PR}$, por outro lado, é a única que estudou apenas em escolas privadas e corrobora a opinião das colegas. Interessante é ler suas considerações a respeito da questão 13, que motiva as participantes a uma "avaliação" sobre a grade curricular do curso de Pedagogia:

Quadro 23. Avaliação das discentes que julgam insuficiente a grade curricular do curso de Pedagogia

\begin{tabular}{|c|c|}
\hline Participante & \multicolumn{1}{|c|}{ Depoimento } \\
\hline Estudante 2PB & $\begin{array}{l}\text { Acredito que a universidade não tem mais a obrigação de 'ensinar' os } \\
\text { alunos a escrever mas sim a instruí-los como ensinar as crianças. }\end{array}$ \\
\hline
\end{tabular}




\begin{tabular}{|c|c|}
\hline Estudante 7PB & Acho que deveria ter mais uma matéria para exercitarmos mais a escrita. \\
\hline Estudante 13PB & Porque são poucas as disciplinas que trabalham está questão. \\
\hline Estudante 14PB & $\begin{array}{l}\text { Acredito que deveria ter mais disciplinas como a de Leitura e Escrita. } \\
\text { Pois assim, os alunos não ficam presos a produção acadêmica. }\end{array}$ \\
\hline Estudante 15PB & $\begin{array}{l}\text { A escrita é fundamental na profissão docente, precisamos de mais } \\
\text { disciplinas a cerca da leitura e escrita. }\end{array}$ \\
\hline Estudante 16PB & Deveria haver mais disciplinas voltadas para produção de textos. \\
\hline Estudante 17PB & $\begin{array}{l}\text { Minha justificativa é com referência ao currículo antigo que é referente } \\
\text { ao meu curso. }\end{array}$ \\
\hline Estudante 18M & Só temos uma disciplina obrigatória que aborde essa temática. \\
\hline Estudante 19PB & Não respondeu \\
\hline Estudante 20NR & $\begin{array}{l}\text { Apenas uma ou duas disciplinas eram direcionadas à escrita. Não } \\
\text { considero suficiente. }\end{array}$ \\
\hline Estudante 21PR & Não respondeu \\
\hline Estudante 22PB & $\begin{array}{l}\text { Acredito que deveriamos ter mais disciplinas voltadas para a leitura e a } \\
\text { escrita. }\end{array}$ \\
\hline Estudante 23PB & $\begin{array}{l}\text { Acredito que poderiam haver mais disciplinas de leitura e escrita, e de } \\
\text { produção textual. }\end{array}$ \\
\hline Estudante 24M & Não respondeu \\
\hline Estudante 25PB & $\begin{array}{l}\text { Porque deveria ter aulas extras desde o primeiro período, ou seja, auxílio } \\
\text { contínuo em horários extracurriculares. }\end{array}$ \\
\hline
\end{tabular}

(conclusão)

Praticamente todas as participantes realizam uma conexão entre a adequação do curso para ajudar quem precisa de apoio na escrita à quantidade de disciplinas disponibilizadas. A estudante $2 \mathrm{~PB}$, porém, apresenta uma visão mais abrangente da situação ao relacionar o espaço universitário com um viés diferenciado da escrita, com o processo de ensino que o professor terá que enfrentar. Pode-se subentender, dessa maneira, uma inclinação para a responsabilização da Educação Básica.

Um total de 9 participantes (35\%) considerou o currículo suficiente. Um olhar atento para o quadro abaixo permite-nos perceber que a maioria delas possuem formação exclusivamente em escolas privadas (5 participantes - 19,2\%) e que apenas uma possui formação apenas em escolas públicas - Estudante 10PB. 
Quadro 24. Perfil das alunas que consideram o currículo do curso suficiente

\begin{tabular}{|c|c|c|}
\hline Participante & EF & EM \\
\hline Estudante 1 & Privada & pública \\
\hline Estudante 3 & Privada & privada \\
\hline Estudante 4 & Privada & privada \\
\hline Estudante 5 & Pública & misto \\
\hline Estudante 6 & Privada & privada \\
\hline Estudante 8 & Privada & privada \\
\hline Estudante 10 & Pública & pública \\
\hline Estudante 11 & misto & pública \\
\hline Estudante 12 & privada & privada \\
\hline
\end{tabular}

Com base nesse panorama, para o grupo de participantes, como um todo, a principal medida a ser tomada para ajudar estudantes com necessidade de apoio é em primeiro lugar a criação de espaços específicos, com uma equipe especializada; em segundo lugar um acompanhamento individualizado com o professor fora do horário de aula.

\subsubsection{Perspectivas dos docentes}

Os docentes, por sua vez, realizaram uma avaliação mais qualitativa quanto à percepção da grade curricular. Obtivemos respostas que englobam tanto perspectivas que apoiam a grade curricular atual quanto posições que defendem uma maior abrangência da mesma. Dois professores (P5 e P7) não responderam à questão por não se considerarem aptos para realizar tal análise. Examinemos o quadro ilustrativo abaixo que resume as concepções dos docentes:

Quadro 25. Avaliação dos professores quanto à grade curricular do curso

\begin{tabular}{|c|c|}
\hline Professor & Percepção da grade curricular \\
\hline P1 & A grade curricular é universal \\
\hline P2 & É preciso um trabalho coletivo dos professores \\
\hline
\end{tabular}




\begin{tabular}{|c|c|}
\hline P3 & A grade curricular ajuda \\
\hline P4 & $\begin{array}{l}\text { A grade atual é o melhor que foi possível fazer; é preciso colaboração } \\
\text { de outros departamentos }\end{array}$ \\
\hline P5 & Não respondeu \\
\hline P6 & Apenas uma disciplina obrigatória é pouco \\
\hline P7 & Não respondeu \\
\hline P8 & A disciplina optativa deveria ser obrigatória \\
\hline P9 & A grade curricular ajuda \\
\hline P10 & $\begin{array}{l}\text { Os alunos já têm uma disciplina que podem cursar por vários semestres; } \\
\text { inclusão de disciplina de produção de texto }\end{array}$ \\
\hline P11 & Já existem 4 disciplinas de leitura e escrita \\
\hline P12 & Já existe uma preocupação com aspectos da escrita \\
\hline PE13 & Já existem 4 disciplinas de leitura e escrita \\
\hline PE14 & A disciplina obrigatória deveria ter maior duração \\
\hline PE15 & Já existem 4 disciplinas de leitura e escrita \\
\hline
\end{tabular}

(conclusão)

O professor que percebe a grade curricular de forma global, não só para a instituição em questão, mas também como base para outras, é P1. Afirma ele que "Eu não sei a grade curricular, porque eu acho que não é uma grade voltada para os alunos com dificuldade, é uma grade em um currículo universal, para todos, digamos assim [...] eu não acho que a grade curricular tenha nada especial para isso, que tenha sido pensado para isso, ou que tenha alguma disciplina pensada, mas sim que a longo do tempo a gente tem refletido sobre isso e têm atitudes individuais dos professores e tem também essas disciplinas...". Reparemos que, ao mesmo tempo que o P1 indica que a grade é construída de modo universal, sem focalizar nas dificuldades dos alunos, também faz menção à importância do trabalho do professor em sala de aula.

P2 também destaca a importância do trabalho coletivo entre os próprios professores e assume que são poucos os espaços para discutir problemas do tipo: "Eu acho que isso tinha que ser, de certa maneira, uma responsabilidade de todos os professores, eu acho que isso é uma questão que tinha que ser assumida mais coletivamente. Aí eu acho, por exemplo, que a gente tem pouquíssimos espaços de troca [...] Eu acho que ultimamente está cada um fechado dentro da sua caixinha”.

Para P3 e P9, a grade curricular atual ajuda os alunos que apresentam dificuldades na escrita. Sobre as duas disciplinas focalizadas neste estudo, P3 afirma 
que elas ajudam os alunos e, especificamente sobre a disciplina obrigatória, o professor ainda exemplifica sua importância relatando um acontecimento recente: “ $E$ eu acho que essas duas disciplinas elas ajudam, elas contribuem. A obrigatória hoje na turma de primeiro período, teve uma aluna que comentou assim 'professora, nós estamos fazendo essa disciplina. Porque que ensinaram errado a gente o que que é um resumo? Eu no meu ensino médio todo eu entendi que, aprendi que resumo era uma coisa, e agora na obrigatória mentiram para mim, resumo não é o que eu achava, a professora que dá falou que resumo é outra coisa. Por que me ensinaram errado?', foi a pergunta que ela me lançou hoje, especificamente com relação a o que é um resumo, o que é uma resenha. Por que a obrigatória trabalha também alguns outros aspectos que contribuem para a escrita, claro”.

P9, nesse mesmo viés, reconhece que possivelmente existem estudantes com dificuldades na escrita, mas que a universidade é capaz de proporcionar toda a base necessária para que esse futuro professor consiga se aprimorar cada vez mais: "acho que eles sempre saem melhores do que entraram, sem dúvida nenhuma. [...] Então eu acho que todos melhoram, alguns melhoram muito, alguns já chegam bons e melhoram alguma coisa, mas também tenho clareza que alguns saíram com muitas dificuldades de escrita e foram diplomados, formados etc, mas eu tenho para mim que eles ganharam ou adquiriram aqui as habilidades necessárias para continuar o investimento que é para a vida toda para continuar escrevendo.

P4 afirma que a grade curricular atual da Pedagogia é resultado de um consenso de uma reorganização curricular, sendo classificada como "o melhor que conseguimos fazer". O mesmo professor ainda intensifica a necessidade de especialistas para trabalhar com os alunos e uma maior duração do curso: "[...] você precisaria ter, talvez, um número maior de pessoas especializadas em outras áreas e muito mais tempo de curso para dar conta de todas essas coisas como se deveria ser. Eu diria que um aluno, salvo engano, de um modo geral, um aluno de pedagogia teria que estudar tempo integral, pelo menos três anos, depois começar a fazer estágio com acompanhamento etc e tal [...] E aí a pergunta também é quem mais iria nos ajudar, porque algumas áreas você tem na universidade, Letras, História, 
Geografia, agora tem até Biologia e várias; de Física, não tem licenciatura, Matemática, não tem licenciatura, será que esses departamentos estariam interessados em nos ajudar a formar nossos alunos e tirar a defasagem deles nessas áreas? Mesmo o pessoal que tem suas licenciaturas, será que estariam interessados de verdade, seria possível contar com eles para colaborar nisso?”.

P6 afirma que a existência de apenas uma disciplina obrigatória para trabalhar com alunos a questão da escrita é pouco, corroborando a posição de PE14, que também indica necessidade de maior duração de tal disciplina. Já P8 opina que a disciplina optativa deveria ter caráter obrigatório. Apenas quatro professores (P10, P11, PE13 e PE15) mencionam a nova proposta da grade curricular do curso de Pedagogia, que é a inclusão de quatro disciplinas optativas de leitura e escrita, percebendo-as como suficientemente necessárias para suprir as dificuldades existentes.

P12, apesar de não realizar referências aos tipos de mudança que a grade sofreu, relata que o Curso está preocupado sim com a questão da escrita dos estudantes de Pedagogia, mas que ainda não é possível perceber os resultados da eficácia desse novo cenário, visto que o currículo foi recentemente atualizado. Afirma ele que " [...] suficiente nunca é. Eu acho que a gente nunca chega ao ideal, mas penso que nessa ultima mudança da grade curricular, essa foi uma das preocupações do curso, e a gente conseguiu avançar em algumas coisas, me parece. Se a gente vai conseguir

ajudar mais efetivamente eu acho que a experiência vai dizer para a gente. $O$ currículo novo, na verdade, está sendo colocado em prática agora, a gente não tem uma resposta, mas foi uma das preocupações”.

\subsubsection{Outras sugestões}

Com base na avaliação da grade curricular do Curso, os participantes eram convidados a sugerir possíveis caminhos para ajudar os alunos que têm dificuldades na escrita. Os professores foram desafiados a propor medidas ou trabalhos para que o 
curso complementasse (caso considerassem insuficiente) ou incrementasse (caso considerassem o currículo plenamente positivo) a área de intervenção da produção escrita dos discentes.

Foi possível obter diferentes opiniões e propostas dos docentes, sendo elas:

1. proporcionar maior contato dos alunos com outros ambientes culturais;

2. criar uma minibiblioteca;

3. criar oficinas;

4. aumentar o tempo de curso;

5. promover a prova de nivelamento em todas as áreas do conhecimento;

6. incentivar o trabalho especializado da universidade (núcleo já existente) $)^{23}$ com alunos que apresentam questões de leitura e escrita

7. desenvolver a leitura para aprimorar a escrita;

8. envolver pessoas especializadas em Língua;

9. promover recuperação paralela; e

10. incentivar o trabalho coletivo dos professores.

Todos os professores, quando indagados sobre de quem é o papel de intervenção na escrita, afirmam que o trabalho deve ser de qualquer docente. Mesmo não sendo a área de atuação direta da disciplina, o professor precisa ser sensível às dificuldades e facilidades de um grupo, de modo a possibilitar uma intervenção positiva no momento necessário. Entretanto, quando um professor não puder ser capaz de proporcionar essa interação, ele precisa, no mínimo, orientar o aluno sobre possíveis meios que possam ajudá-lo.

Conforme sugere P11: "[...] acho que se todos nós fizermos isso em nossas disciplinas como uma parte normal do currículo eu acho que isso seria melhor”. Do mesmo modo, acrescenta P12: "Eu acho que é tarefa de todo professor porque a gente aprende a escrever escrevendo, e eu só modifico a minha escrita se eu sou

\footnotetext{
${ }^{23}$ A universidade pesquisada já conta com um núcleo de atendimento para alunos em leitura e escrita, mas que apenas começou a funcionar recentemente. Não mencionaremos o nome do núcleo a fim de preservar o anonimato dos participantes.
} 
orientada para isso. Eu não aprendo sozinha, a minha escrita não vai evoluir, não vai ser modificada simplesmente pelo exercício da escrita. Eu preciso de uma intervenção para isso, uma intervenção que eu considero que precisa ser pedagógica. Eu preciso ter alguém que me mostre como é que eu posso fazer diferente, como é que eu posso fazer melhor".

P9 vai ao encontro dessa ideia de trabalho coletivo e acredita no incentivo dele conjuntamente com a elaboração de exercícios contínuos em sala por parte do professor e realizados pelo aluno, de forma dialógica. O Professor classifica ainda a prova de nivelamento como desnecessária, diferentemente de P4 e P5, conforme já demonstrado em tópico anterior. Esse professor (P9), juntamente com P1, são os únicos que mencionam um trabalho especializado com questões de leitura e escrita. Ambos não sabem como o trabalho funciona especificamente, mas opinam que as atividades com a escrita precisam ocorrer de modo processual.

P8 também concorda com o incentivo desse trabalho coletivo entre os professores e, como já demonstrado em tópicos anteriores, critica o pouco espaço e atenção que é conferido à importância da escrita no espaço universitário: “Eu acho que isso tinha que ser, de certa maneira, uma responsabilidade de todos os professores, eu acho que isso é uma questão que tinha que ser assumida mais coletivamente [...] a gente têm pouquíssimos espaços de troca. As reuniões que a gente têm [...] acabam sendo muito burocráticas e eu acho que a gente socializa pouco. As poucas vezes a gente consegue fazer uma reunião em que a gente discuta um pouco mais essas questões mais acadêmicas do curso, todo mundo sai satisfeito, só que são pouquíssimas ocasiões. Eu acho que ultimamente está cada um fechado dentro da sua caixinha. E eu acho que essa era uma questão que tinha que ser assumida coletivamente pelo corpo de professores".

Esse último professor ainda completa suas considerações ao incluir como sugestão a criação de minibibliotecas que funcionassem com indicação de textos fundamentais para desenvolver a leitura e a escrita, que estão entrelaçadas. PE15 também destaca a importância da relação entre a leitura e a escrita, sugerindo que o trabalho do curso deveria ser inicialmente motivado com leituras significativas: "Não 
adianta querer fazer escrever quem não tem o que dizer. Lendo, o aluno, além de se informar, passa a ter contato com estruturas complexas, bem organizadas. Acho que no fundo todo escritor se inspira em algum autor. Seja no estilo, na forma mais técnica. Então, é preciso diversificar, mostrar caminhos. Motivar a ler. Eu iria além: ensinar a ler. Esmiuçar os parágrafos junto com os alunos, pensar na palavra, quebrá-la ao meio, ver o que significa”.

P6 já apresenta um viés mais cultural e sugere atividades que ampliem esse tipo de repertório: "[...] eu tenho impressão que para quem vai ser professor, que vai lidar com a coisa da cultura dos alunos e vai lidar com o conhecimento acumulado, digamos, das sociedades, eu acho que a exposição a práticas culturais deveria ser mais incentivada, esse aluno ir a exposições, ampliar a leitura do mundo para além do conhecimento científico das disciplinas que ele tem no seu curso. Acho que a exposição à cultura, ao teatro, ao cinema, música são práticas muito importantes, fazem parte da formação cultural desse professor”.

A criação de oficinas é sugerida por P3 nas quais os próprios alunos seriam os responsáveis pelas atividades do "centro", conforme a seguir: "Um jornal, propor alguma atividade através do CA, um jornal da Pedagogia que teria que ser pelo próprio $C A$, pelos estudantes, envolvendo algumas atividades que fossem conjuntas com os alunos, acho que seria interessante, acho que seria bacana”. O Professor 4 menciona também a importância da participação de pessoas especializadas nas mais diversas áreas do conhecimento para dar um suporte mais significativo aos estudantes, do mesmo modo como sugere um tempo maior para a duração do Curso.

A estratégia de recuperação paralela é sugerida por PE14 como um reforço, de modo que ocorressem encontros semanais para apoiar os alunos que precisam.

\subsection{Relação com a Educação Básica}

Existem pesquisas que retratam o desempenho de estudantes universitários como relacionado à sua trajetória na Educação Básica. 
Para Marin e Giovanni (2007), a escola básica não tem conseguido cumprir sua função principal, que é a de promover um crescimento holístico do aluno frente a seu contexto social. Afirmam elas que

[...] é muito presente a necessidade de que a escola retome sua função básica de cuidar adequadamente de aspectos culturais referentes aos seus estudantes, para que não cheguem ao ensino superior em condições tão precárias, após 14 anos de escolarização, mantendo ainda as condições de não provimento de tais aspectos originários de seu ponto de partida social e familiar. (MARIN \& GIOVANNI, 2007, p. 25)

\begin{abstract}
Kretschmann, Conceição e Minuzzi (2013) relatam que as lacunas que os universitários apresentam provêm de processos desde a alfabetização e que o ensino da Língua é realizado nas escolas de modo não significativo e descontextualizado. De acordo com as autoras,
\end{abstract}

Ao longo dos anos, tem-se percebido que os acadêmicos, ao ingressarem numa instituição de nível superior, trazem uma deficiência não sanada no ensino secundário quanto ao uso da sua própria língua. Pode-se dizer que essa dificuldade vem desde a alfabetização. Uma dessas constatações é a questão referente à redação de ingresso via vestibular. A causa direta desse tipo de postura está relacionada ao ensino da própria língua, que se vincula, predominantemente, no tipo de ensino da gramática normativa, ou seja, a gramática que dita as normas de bem falar e escrever. Essa prescrição linguística para a correta forma de escrever é uma modalidade de gramática baseada na lei que regula o seu uso em uma sociedade. E é esse ensino em nossas escolas que tem se caracterizado de forma efetiva e traumática, apegando-se a regras sem aplicabilidade que é exigida para a comunicação. (KRETSCHMANN, CONCEIÇÃO \& MINUZZI, 2013, p.1-2).

Ainda de acordo com as mesmas, seria necessário na escolarização básica trabalhar em torno de atividades também funcionais da língua para que o aluno conseguisse chegar plenamente no nível superior sem a necessidade de preocupações com questões de escrita e também leitura: 
Se, desde as séries iniciais do ensino de nosso idioma, fosse possível desenvolver habilidades de leitura e produção escrita de seus alunos, com ênfase nas relações funcionais dos elementos que compõem um texto, sua capacitação para o exercício de ler $e$ escrever certamente os alçaria paulatinamente para voos reflexivos sobre a linguagem. Chegariam na universidade sem necessitar de estudos adicionais e com isso avançar de forma mais célere o seu conhecimento. (KRETSCHMANN, CONCEIÇÃO \& MINUZZI, 2013, p.3).

Sacramento e Sobral (2013) também percebem a existência de lacunas que a escolarização básica não é capaz de suprir nos alunos e sugerem que o ensino superior no Brasil precisa se preocupar e se comprometer em sanar as dificuldades que não foram devidamente trabalhadas no nível anterior, "a fim de garantir o binômio quantidade e qualidade educacional tão necessário para que o país se desenvolva de forma sustentável” (SACRAMENTO \& SOBRAL, 2013, p. 12).

Entretanto, discutir a relação dos estudantes com a educação básica não foi uma preocupação inicial deste estudo, principalmente devido à amplitude do assunto. Porém, sem mesmo mencioná-lo, o tópico surgiu nos depoimentos dos docentes e também das discentes. Foram no total quinze citações: de quatro alunas e de seis professores. É importante ressaltar que a soma das parcelas discriminadas não corresponde ao total apontado, visto que um participante pode ter feito a citação mais de uma vez. Dentre todas, apenas uma tem um registro positivo - de uma aluna. Todas as outras citações fazem referência a tal nível de Educação de maneira negativa.

Apenas uma aluna registrou memórias positivas em relação à Educação Básica: Estudante 14PB. Para ela, a exigência do Ensino Médio para com o vestibular a estimulou no processo de produção da escrita: “[...] desde lá o Ensino Médio eu sempre tive, por causa do vestibular, eu tive um ano inteiro só de redação, eu tive só uma disciplina de redação. Então, foi o ano inteiro tendo aula duas, três vezes na semana. Então, já foi aperfeiçoando a escrita, não que eu não cometa erros, de interpretação, coerência, coesão, falando ou escrevendo, mas eu acho que eu já tenho uma prática maior desde o ensino médio”. 
Porém, essa é uma visão contrária à da Estudante $5 \mathrm{M}$, que "denuncia" justamente essa preocupação exclusiva com provas: “[...]É que no Ensino Médio é uma coisa mais de sistema, tipo Enem. Aqui a professora tem mais disponibilidade para gente chegar para ela, e ela parar a aula e falar só comigo sobre algum conceito, eu posso pedir para ela isso. E ela a professora só queria passar um tema, e você tinha que saber exatamente isso e acabou, porque amanhã é o vestibular".

Essa percepção também é partilhada pelo Professor 11, que também critica severamente o sistema de avaliação e a postura que a escola tem que tomar diante das situações nas quais precisa supostamente demonstrar um alto valor em suas qualificações. Ele afirma que esse problema é proveniente do Ensino Médio, “uma pessoa recém ingressa na universidade falou 'nossos professores do ensino médio nos deram modelos de resposta para redação e a gente só precisava modificar alguma coisa aqui e ali e encaixa em qualquer pergunta e o resto é múltipla escolha'. Então, se vai se ensinar assim, como vai desenvolver a capacidade de raciocinar? $O$ culpado principalmente é o sistema de avaliação que cobra esse tipo de resposta do aluno. Ela confessou isso para mim ontem, eu falei 'pelo menos na redação você aprende' e ela falou 'não, aprendo não'. Decora o modelo e dependendo da pergunta modifica aqui e ali e ponto".

A Estudante 20 estabeleceu uma relação com a Educação Básica enfatizando a leitura e a escrita, informando que no Ensino Médio a leitura ocorria apenas por ser obrigatória: “[...] porque pelo menos eu, no ensino médio, eu não lia praticamente nada. Eu lia assim, livro didático, o que era obrigado a ler. Eu não tinha o hábito de eu mesma pegar um livro e ler. Então ele foi muito nesse sentido, eu comecei a ler vários textos”. Já a Estudante 21PR afirma que os alunos chegam à Universidade com uma defasagem muito grande e que essa situação é "comum a todos": "[...] $a$ gente chega com uma defasagem muito grande. E eu acho que isso é geral”.

O Professor 14 lista uma série de dificuldades que os alunos apresentam, afirmando que existe uma diferença entre o que deve ser aprendido em cada tipo de espaço escolar e a quantidade de tempo que é necessária para esse aprendizado: “[...] então eles apresentam dificuldade de planejamento, de argumentação, argumentação 
superficial, por isso que eu digo que precisaria de mais tempo, porque são problemas que não são resolvidos de uma hora para outra. A gente consegue resolver a materialidade da língua, 'diante de uma palavra masculina não se usa crase', mas como eu posso ajudar o aluno a trabalhar a argumentação, mostrar para ele que, se ele disser algo assim e não dar exemplo, então ele precisa saber argumentar exemplificando. Eu falo muito da citação como argumento de autoridade, 'segundo fulano', que é o protocolo do texto acadêmico. Então a dificuldade vem daí, até porque também não é trabalhado, isso não é tão bem trabalhado nas escolas em geral".

O professor 12 praticamente complementa as ideias do anterior, obviamente mesmo sem saber, ao apontar que a Educação Básica é precária e que sempre é necessária uma intervenção de terceiros para apoiar os alunos, tanto nas escolas quanto nas universidades. Coloca-se na posição de aluno e afirma: “[...] preciso ter alguém que me mostre como é que eu posso fazer diferente, como é que eu posso fazer melhor, especialmente em se tratando de ensino superior, porque a gente está falando de alunos que já passaram por aulas de língua portuguesa a vida inteira durante a educação básica, a gente não está falando de alunos lá do primeiro segmento que estão agora aprendendo, embora lá também eu acredite nessa intervenção, eu estou respondendo pensando nessas alunas especificamente”.

Já o Professor 15 retrata outra correspondência com a escolarização básica. Para ele, a escrita é pouco trabalhada nas escolas sim, mas também o é nos espaços universitários: "os graduandos têm chegado com pouca experiência em escrita. Às vezes passam pela universidade sem viver essa experiência e, muitas das vezes, chegarão às escolas, onde lecionarão, sem saber como escrever e, muito menos, sem saber como trabalhar com ela (a escrita). Isso independe da área de atuação, seja nas letras, na geografia, na história..." Observe-se que esta é uma transcrição da fala de um professor de uma disciplina específica estudada nesta pesquisa. Caracteriza-se como o único docente que menciona também a importância das universidades no processo de desenvolvimento da escrita de um estudante, futuro professor. 
O Professor 2, como já apresentado em tópico anterior, associa o desempenho dos alunos com o perfil dos trabalhadores da carreira docente e com as "deficiências" provenientes da Educação Básica: “cada vez mais o pessoal que procura a carreira docente é o pessoal que vem das camadas mais populares, que vem da escola pública, que portanto traz uma série de deficiências na sua formação básica. Então eu acho que o problema não é do curso, o problema é de quem está procurando esse curso."

O Professor 4 é o mais crítico de todos. Estabelece uma relação entre a Educação e o desenvolvimento do país: “[...] a Educação está precária porque eu acho que a gente não pode esquecer que a educação básica nesse país tá muito mal, tem algumas poucas ilhas de qualidade e os alunos não chegam à universidade. Não é culpa deles. Via de regra não chegam à universidade com os conteúdos que a gente esperaria que eles tivessem". Além disso, classifica a escola pública como vagabunda, "eximindo, de certa forma, a responsabilização" da atuação discente: “com certeza, não tenho nenhuma dúvida disso. Acho que parte também no que se refere à formação de professores, que pega muito gente que vem dessa escola pública vagabunda que está aí, eu acho que aí é mais ainda necessário esse trabalho [...] porque é uma temeridade você depois jogar no mercado de trabalho e a pessoa com buracos na sua formação que não foi culpa dela, não foi ela que construiu, foi uma escola de má qualidade que ela, às vezes, foi a única que ela pôde frequentar”.

Acrescenta, ainda, o Professor 4 que este é um problema não apenas relacionado à escolarização, mas também ao próprio "perfil”" dos alunos que buscam área da carreira docente: "eu acho que é uma coisa que vem da educação básica de quem procura essas áreas, as licenciaturas e inclusive Pedagogia, muita gente vem de escolas, mais da metade vem das escolas públicas, de uma escolarização da escola pública, infelizmente em uma escola pública quase sempre de péssima qualidade aonde não foi desenvolvida a linguagem da maneira como acho que deveria ter sido, mas como também não foram desenvolvidas várias outras coisas, conteúdos de História, de Geografia, de Matemática [...] Então tem uma carência de conhecimento geral, não só na escrita não”. 


\section{Considerações finais}

De acordo com Leta (2005, p. 52), “uma das características mais importantes das sociedades modernas é a presença da escrita em quase todos os eventos significativos".

Camargo e Britto (2011) acreditam que a escrita é a base para o aprendizado de outros conhecimentos. Nesse sentido, Cabral e Tavares (2005) enfatizam a importância de determinados conhecimentos essenciais para o atual mundo da informação, e que as habilidades de leitura e escrita são essenciais para o sucesso acadêmico. Damiani et al (2011), ao realizarem um diagnóstico e análise dos problemas de escrita de estudantes de Pedagogia, percebem que as atividades de escrita desses estudantes são impulsivas, sem reflexão, planejamento e atenção.

Com tantas informações, uma dúvida paira: que tipo de instituição universitária consegue preparar um bom Pedagogo, para atuar nas séries iniciais do Ensino Fundamental? Certamente, as que percebem onde estão localizadas as dificuldades do grupo e trabalham em cima disso. As propostas das disciplinas estudadas neste trabalho revelam que as percepções dos discentes quanto à sua própria escrita mudam conforme o desenrolar de atividades que proporcionam sempre uma ampliação de repertório de conhecimentos, que apresentam aos alunos aspectos ainda não vivenciados por eles.

Nesse sentido, a escrita deve ser pensada como um processo. No presente estudo de caso, revelou-se que quando se trabalha nas "lacunas" que os graduandos apresentam, os resultados são significativamente positivos, conforme demonstram os depoimentos apresentados. Registremos que a atuação dos docentes na ampliação das bases de conhecimento armazenadas na memória de longo prazo dos alunos, conforme Flower e Hayes (1980), produziu efeitos expressivos no que tange ao progresso deles e suas autoavaliações em relação à própria escrita.

De acordo com o modelo de processamento cognitivo da escrita de Flower e Hayes (1980), foi possível perceber que todos os professores das disciplinas 
estudadas trabalham no sentido de aprimorar conhecimentos, que implicarão na melhor desenvoltura da memória de longo prazo. Do mesmo modo que os professores indicam os trabalhos nesse sentido, os alunos também manifestam suas reações apontando o quão importante foi essa ampliação de repertório. A exceção foi o grupo da disciplina obrigatória, na qual havia um verdadeiro embate: enquanto os alunos queriam aprender mais, avançar no conteúdo, o professor limitou o campo a partir da perspectiva de que é necessário primeiro dominar o básico para avançar para o complexo.

Refletir sobre o processamento da escrita auxilia o próprio professor a traçar estratégias de trabalho. Se ocorre o domínio consciente das diferentes etapas que a escrita envolve, é possível promover e executar um caminho mais adequado para intervir no desempenho dos alunos. É isso que os graduandos de Pedagogia precisam conhecer e é isso que os professores do Curso precisam esclarecer.

Além dos aspectos cognitivos, também é preciso considerar as dimensões social e afetiva/motivacional, conforme apontado na seção 4.3.1. (Dificuldades apresentadas: avaliação dos discentes e dos docentes). Apesar de o tópico ter sido pouco explorado neste estudo, devido à amplitude teórica do assunto, fica claro que este é um componente que interfere na produção escrita e que precisa ser enfatizado em estudos posteriores. A autoria, da mesma forma, também é um aspecto relevante quando o assunto é a produção escrita de estudantes universitários. A apropriação de conteúdos e de textos é necessária para a autonomia da escrita, para o desenvolvimento da autoria.

Ao incorporar pressupostos de outros teóricos sobre o tema, identificou-se que esse assunto está muito atrelado à Educação Básica. Tanto os professores quanto os alunos mencionam essa relação de forma negativa, alegando que tal nível da educação está voltado para preocupações com o vestibular, apresentando caráter mais técnico. A Educação Básica tem um papel fundamental na formação e desenvolvimento de um indivíduo. Quando ocorre de forma insuficiente ou reduzida, pode acarretar graves problemas na trajetória educacional de uma pessoa, conforme declarado pelos participantes da pesquisa. É necessária uma maior atenção a este 
nível, com vistas a promover uma educação de qualidade e que forneça os suportes básicos e essenciais para um aluno conseguir ingressar e permanecer no espaço universitário integralmente, com o mínimo de lacunas possível.

Considerando que a maioria das alunas avalia a grade curricular da universidade como insuficiente e que elas possuem, em sua maioria, formação exclusivamente em escolas públicas, questiona-se: o curso de Pedagogia deve se encarregar da defasagem proveniente da Educação Básica? Se sim, como?

A universidade estudada claramente mostra preocupação com a leitura e escrita, já que exige um nível mínimo de proficiência. Mas, além disso, foi possível perceber que no Curso de Pedagogia existem iniciativas proativas, no sentido de auxiliar estudantes que necessitam de apoio na leitura e na escrita. Tais iniciativas estão consubstanciadas basicamente em duas vertentes atuais: nas disciplinas que são oferecidas, sejam elas obrigatórias ou optativas e em um trabalho específico e especializado em leitura e escrita (conduzido por um núcleo da universidade), que, apesar de não ter sido explorado neste trabalho, foi mencionado por alguns professores como caminho para auxiliar nesse percurso formativo.

Além disso, também há a questão do nivelamento, que surgiu no estudo de modo interessante e que também pode auxiliar estudantes com dificuldades na escrita. Entretanto, é necessário refletir que para ser eficaz, o nivelamento precisa ter realmente uma feição de projeto. Realizar apenas uma prova, sem proposição de atividades para a resolução dos problemas, certamente não auxiliará na superação de uma dificuldade de um estudante.

Diante do exposto, fica claro que os estudantes de Pedagogia, futuros professores, apresentam sim dificuldades na escrita.Este é um cenário preocupante e fazem-se necessárias medidas intervencionistas para ajudar esses estudantes, de modo a melhor qualificá-los para o mercado de trabalho e garantir que sejam bons formadores das novas gerações.

Outro resultado que vale discutir foi que apenas um estudante inscreveu-se na disciplina optativa por indicação da coordenação. Todos os outros foram por diferentes motivos, como: acompanhar um colega, melhorar a própria escrita e por ser 
importante para a prática. Aliás, de acordo com o depoimento dos próprios alunos, a intervenção dos professores do Curso é muito fraca - eles realizam correções, atividades, mas em momento algum mencionam se acompanham algum aluno de perto ou se dialogam com os discentes sobre caminhos para melhorar suas desenvolturas. Logo, cabe aí um maior empenho por parte da administração e do corpo docente da universidade. Conforme destaca Santos (2006), a escrita como uma habilidade pode e deve ser desenvolvida nas diversas disciplinas do curso de Pedagogia e não apenas nas relacionadas ao trabalho específico com a língua. Os trabalhos a serem realizados em cursos de formação de professores, especificamente na Pedagogia, precisam investir em atividades que apoiem os estudantes em suas maiores dificuldades. Esses alunos são futuros professores que irão atuar na evolução da escrita de crianças e, por isso, precisam estar aptos e dominar a língua em suas variantes, principalmente as habilidades de escrita.

A partir de todas as considerações realizadas nesta pesquisa, é preciso refletir que este se trata de um estudo de caso, isolado. Mas se levarmos em consideração que os estudantes apresentam dificuldades e que eles serão professores, precisamos nos perguntar: os cursos de Pedagogia, em geral, estão preocupados em auxiliar estudantes com dificuldades na escrita? Como os estudantes se avaliam após o curso? Para obter um panorama real da situação dos estudantes de Pedagogia, será necessário uma pesquisa mais global, do ponto de vista de abrangência. Para conseguirmos propor medidas que auxiliem os futuros professores, precisamos ampliar nossa visão e nosso campo de pesquisa, estudando instituições e atores com diferentes perfis. Desse modo, será possível compreender o verdadeiro cenário da formação de professores e sua preocupação com questões de escrita. 


\section{Referências bibliográficas}

ABREU, Geysa; BAZZO, Jilvania; GODOY, Dalva. O ensino de língua materna nos currículos do curso de Pedagogia. Revista Educação PUC-Campinas, 2013.

ALMEIDA, Carolina Gonçalves. Erros de ortografia na produção textual dos estudantes de Pedagogia da UFRJ: percepções e propostas. Rio de Janeiro, 2013. Graduação em Pedagogia. Faculdade de Educação, Universidade Federal do Rio de Janeiro, Rio de Janeiro, 2013.

ALVES, Clair. A arte de escrever bem. 7ed. Petrópolis, Rio de Janeiro: Vozes, 2014.

BAGNO, Marcos. Preconceito linguístico: o que é, como se faz. São Paulo: Loyola, 2013.

BARTHES, Roland. O prazer do texto. São Paulo: Editora Perspectiva, 2013.

BECHARA, Evanildo. Ensino da gramática: opressão? liberdade?12 ed. São Paulo: Ática: 2006.

CABRAL, Ana Paula; TAVARES, José. Leitura/compreensão, escrita e sucesso académico: um estudo de diagnóstico em quatro universidades portuguesas. Psicologia Escolar e Educacional, 2005, v. 9, n. 2, p. 203-213.

CAMARGO, Márcio; BRITTO, Luís. Vertentes do ensino de Português em cursos superiores. Revista Avaliação, Campinas, 2011.

CORREAA, Priscila Monteiro. O letramento do professor em formação inicial e o futuro professor como "agente de letramento". Dissertação de Mestrado. Rio de Janeiro: UFRJ, 2010.

CORRÊA, Priscila Monteiro. Os desafios encontrados por alunos do curso de Pedagogia na relação com a leitura e com a escrita na universidade. Revista contemporânea de Educação, n. 12, 2011. 
CUNHA, Neide; SANTOS, Acácia. Relação entre a compreensão da leitura e a produção escrita em universitários. Psicologia: reflexão e crítica, 19 (2), 237-245 2006.

DAMIANI, Magda; ALVES, Clarice; FRISON, Lourdes; MACHADO, Rejane Flor. Diagnóstico e análise dos problemas da escrita acadêmica de estudantes de Pedagogia. Linguagem e ensino, Pelotas, 2011, v. 14, n. 2, p. 455-478.

FARACO, Carlos Alberto; TEZZA, Cristóvão. Prática de texto para estudantes universitários. 24 ed. Petrópolis, Rio de Janeiro: Vozes, 2014.

FIAD, Raquel Salek. A escrita na universidade. Revista Abralin, v. eletrônico, n. especial, p. 357-369. $2^{\mathrm{a}}$ parte 2011.

FLOWER, Linda; HAYES, John R. A cognitive process theory of writing. College Composition and Communication. Vol.32, n. 4 (Dec. 1981), p. 365-387.

GARCEZ, Lucília Helena do Carmo. Técnica de redação: o que é preciso saber para escrever bem. 3 ed. São Paulo: Martins Fontes, 2012.

GERALDI, João Wanderley (org). O texto na sala de aula. São Paulo: Ática, 2011. GNERRE, Maurizio. Linguagem, escrita e poder. $5^{\mathrm{a}}$ ed. São Paulo: Editora WMF Martins Fontes, 2009.

KLEIMAN, Ângela. O conhecimento prévio na leitura. IN: Texto e leito: aspectos cognitivos da leitura. São Paulo, Pontes: 2004.

KOCH, Ingedore G. Villaça. A coesão textual. 22 ed., $3^{\text {a }}$ reimpressão - São Paulo: Contexto, 2014.

KOCH, Ingedore G. Villaça; ELIAS, Vanda Maria. Ler e escrever: estratégias de produção textual. 2ed. São Paulo: Contexto, 2015.

KOCH, Ingedore G. Villaça; TRAVAGLIA, Luiz Carlos. A coerência textual. 18 ed, $2^{\mathrm{a}}$ reimpressão - São Paulo: Contexto, 2013.

KRETSCHMANN, Ângela; CONCEIÇÃO, Celso Augusto Nunes da; MINUZZI, Marcelo. Programa de nivelamento em Língua Portuguesa para o Curso de Direito. Anais da VI Mostra Científica do Cesuca. V.1, n. 7, 2013.

LETA, Maria Masello. Relações de professores com a escrita. Rio de Janeiro: H. P. Comunicação Associados, 2005. 
LIBÂNEO, José Carlos. Didática. São Paulo, Cortez: 2013.

LISPECTOR, Clarice. Crônicas para jovens: da escrita e vida. 1ed. Rio de Janeiro: Rocco Jovens Leitores, 2010.

LOPES, Miguel Pais Moreira. O processo de elaboração de resumos acadêmicos: uma análise com base em modelos processuais da escritura e gêneros textuais / Miguel Pais Moreira Lopes; orientadora: Erica dos Santos Rodrigues. - 2011. 147 f. : il. ; $30 \mathrm{~cm}$.

MANCINI, Marta Maria Pasquali. Escrita e oralidade da Língua Portuguesa nos bancos da academia: um estudo de caso dos grupos de Pedagogia de uma instituição particular de ensino. Dissertação de mestrado, Americana, 2012.

MARCUSCHI, Luiz Antônio. Da fala para a escrita: atividades de retextualização. 10 ed. São Paulo: Cortez, 2010.

MARIN, Alda Junqueira; GIOVANNI, Luciana Maria. Expressão escrita de concluintes de curso universitário para formar professores. Cadernos de Pesquisa, v.37, n. 130, p. 15-41, jan/abr. 2007.

MARINHO, Marildes. A escrita nas práticas de letramento acadêmico. RBLA, Belo Horizonte, v.10, n.2, p.363-386, 2010.

OLIVIERI, Márcia. Como escrever melhor: informações e técnicas para a sua redação. Bauru, São Paulo: Idea Editora, 2010.

POSSENTI, Sírio. Sobre o ensino de Português na escola. IN: GERALDI, João Wanderdey (org). O texto na sala de aula. 5ed. - São Paulo: Ática, 2011.

POSSENTI, Sírio. Por que (não) ensinar gramática na escola. Campinas, SP: Mercado de Letras: Associação de Leitura do Brasil, 1996.

RAMOS, Flávia Brocchetto; ESPEIORIN, Vânia Marta. Letramento acadêmico: leitura e escrita na universidade: entrevista com David Russell. Conjectura, v. 14, n. 2, maio/ago. 2009.

SACRAMENTO, Ana Rita Silva; SOBRAL, Louise Cristine Santos. Cursos de nivelamento em Língua Portuguesa e Matemática para estudantes do Ensino Superior? Um estudo exploratório com estudantes dos cursos de Administração e 
Ciências Contábeis de uma IES. XVI SEMEAD - Seminários em Administração. Outubro de 2013.

SAMPAIO, Isabel S.; SANTOS, Acácia A. Angeli dos. Leitura e redação entre universitários: avaliação de um programa de intervenção. Revista Psicologia em Estudo, Maringá, v.7, n., p.31-38, jan/jun. 2002.

SANTOS, Juliana Ormastroni de Carvalho. Leitura e produção de textos escritos na formação do professorando do curso de Pedagogia. Dissertação de Mestrado, PUCCampinas, 2006.

SILVA, Obdália Santana Ferraz. Entre o plágio e a autoria: qual o papel da universidade? Revista Brasileira de Educação v. 13 n. 38 maio/ago. 2008 SOARES, Magda Becker. Aprender a escrever, ensinar a escrever. In: ZACCUR, Edwiges (org). A magia da linguagem. DP\&A:SEPE, 1999.

SOARES, Magda. Linguagem e escola: uma perspectiva social. São Paulo: Ática, 2001.

ZACCUR, Edwiges (org.) Uma entrevista polifônica e virtual com Paulo Freire. In: ZACCUR, Edwiges (org). A magia da linguagem. DP\&A:SEPE, 1999. 


\section{Apêndices}




\title{
Apêndice I - Termo de consentimento Livre e Esclarecido - professor
}

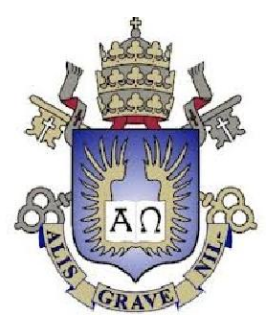

\author{
Pontifícia Universidade Católica do Rio de Janeiro \\ Departamento de Educação \\ Mestrado em Educação
}

Mestranda: Carolina Gonçalves de Almeida

Orientadora: Zena Eisenberg

Coorientadora: Erica dos Santos Rodrigues

\author{
Termo de Consentimento Livre e Esclarecido \\ Prezado/a Professor (a),
}

Convidamos V.S. a participar voluntariamente da pesquisa intitulada "A relação de estudantes de Pedagogia com a escrita", descrita a seguir.

\section{Pesquisadores:}

- Mestranda: Carolina Gonçalves de Almeida

Email: carol_kiu@hotmail.com

Telefone: 96919-3576

- Orientadora: Zena Eisenberg

Email: zwe@puc-rio.br

Telefone: 99640-4038

- Coorientadora: Erica dos Santos Rodrigues

Email: ericasr@puc-rio.br

Telefone: 99131-5721

Justificativa: São poucas as pesquisas no campo educacional que abordam as relações de estudantes de Pedagogia com a escrita - uma perspectiva que se faz necessária diante do fato que são estes os profissionais que irão atuar nas primeiras etapas da Educação Básica e que, por isso, serão os primeiros a iniciar e estimular o contato com a língua, neste caso através da escrita. Uma revisão bibliográfica permite inferir que os cursos de Pedagogia, em geral, não possuem meios para ajudar estudantes com dificuldades. É necessário investigar como realmente ocorre uma prática para ser possível apontar a necessidade ou não de medidas paliativas.

Objetivos: Este estudo busca compreender como os estudantes de Pedagogia se relacionam com a língua escrita e como os professores compreendem essa interação, através de disciplinas específicas $\mathrm{xxxx \times xx}$

Campo de pesquisa: Disciplinas: $\mathrm{xxxxxx}$

Metodologia: Entrevistas, através de audiogravação e/ou videogravação, com duração em média de 60 minutos. A cessão dos planos de aula e atividades realizadas em sala serão solicitados apenas para os professores das disciplinas em foco.

Riscos: Não há riscos físicos ou morais previstos. Todas as informações têm caráter confidencial, sendo a apresentação de resultados realizada através de codinomes ou 
nomes inventados, de modo a impedir a identificação individual de cada participante. A audiogravação e/ou a videogravação serão utilizados apenas em contextos acadêmicos, não sendo divulgados publicamente.

Esclarecimentos: Todas as entrevistas serão sugeridas de ocorrer em datas e horários sugeridos pelo entrevistado, de modo a não prejudicar sua rotina. Ao final do estudo, o participante será informado sobre os resultados da pesquisa. Na ocorrência de qualquer dúvida a respeito da pesquisa, o participante tem liberdade para questionar e até mesmo se retirar da mesma, quando assim julgar conveniente. Este termo é feito em duas vias: uma do participante e outra da pesquisadora.

Benefícios: Com a sua participação, esperamos contribuir para o desenvolvimento científico acerca da relação de estudantes de Pedagogia com a escrita e assim sugerir contribuições para a formação de professores.

$\mathrm{Eu}$, de maneira livre, esclarecida e voluntária, concordo em participar da pesquisa acima explicitada. Estou ciente dos objetivos do estudo, dos procedimentos metodológicos, do assunto, das garantias de confidencialidade e da possibilidade de esclarecimentos permanentes sobre os mesmo. Estou ciente de que se trata de pesquisa de Mestrado em andamento do Programa de Pós Graduação em Educação da PUC-Rio. Está claro que minha participação é isenta de despesas e que minha imagem e meu nome não serão publicados sem minha prévia autorização por escrito. Estou de acordo com a videogravação e/ou audiogravação da entrevista a ser cedida para fins de registros acadêmicos. Estou ciente de que, em qualquer fase da pesquisa, tenho a liberdade de recusar a minha participação ou retirar meu consentimento, sem penalização alguma e sem nenhum prejuízo.

Nome do (a) entrevistado (a) e observado (a):

Email:

Telefone:

Número da identidade:

Autorizo, abaixo, a minha participação no estudo: "A relação de estudantes de Pedagogia com a escrita".

(Participante)

(Mestranda)

(Orientadora)

(Coorientadora)

Rio de Janeiro, , de de 2015. 


\title{
Apêndice II -Termo de consentimento Livre e Esclarecido - aluno
}

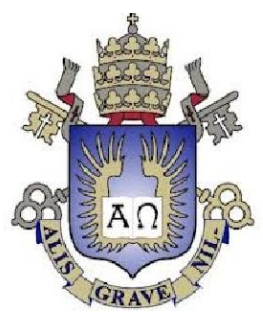

\author{
Pontifícia Universidade Católica do Rio de Janeiro \\ Departamento de Educação \\ Mestrado em Educação
}

Mestranda: Carolina Gonçalves de Almeida

Orientadora: Zena Eisenberg

Coorientadora: Erica dos Santos Rodrigues

Termo de Consentimento Livre e Esclarecido

Prezado/a Estudante,

Convidamos V.S. a participar voluntariamente da pesquisa intitulada "A

relação de estudantes de Pedagogia com a escrita", descrita a seguir.

\section{Pesquisadores:}

- Mestranda: Carolina Gonçalves de Almeida

Email: carol_kiu@hotmail.com

Telefone: 96919-3576

- Orientadora: Zena Eisenberg

Email: zwe@puc-rio.br

Telefone: 99640-4038

- Coorientadora: Erica dos Santos Rodrigues

Email: ericasr@puc-rio.br

Telefone: 99131-5721

Justificativa: São poucas as pesquisas no campo educacional que abordam as relações de estudantes de Pedagogia com a escrita - uma perspectiva que se faz necessária diante do fato que são estes os profissionais que irão atuar nas primeiras etapas da Educação Básica e que, por isso, serão os primeiros a iniciar e estimular o contato com a língua, neste caso através da escrita. Uma revisão bibliográfica permite inferir que os cursos de Pedagogia, em geral, não possuem meios para ajudar estudantes com dificuldades. É necessário investigar como realmente ocorre uma prática para ser possível apontar a necessidade ou não de medidas paliativas.

Objetivos: Este estudo busca compreender como os estudantes de Pedagogia se relacionam com a língua escrita e como os professores compreendem essa interação, através de disciplinas específicas $\mathrm{xxxx \times x}$

Campo de pesquisa: Disciplinas: $\mathrm{xxxxxx}$

Metodologia: Questionários e entrevistas, através de audiogravação e/ou videogravação, com duração em média de 60 minutos. A cessão de trabalhos escritos poderá vir a ser solicitada para compor o campo ilustrativo da pesquisa, sem em qualquer momento expor o pesquisado.

Riscos: Não há riscos físicos ou morais previstos. Todas as informações têm caráter confidencial, sendo a apresentação de resultados realizada através de codinomes ou 
nomes inventados, de modo a impedir a identificação individual de cada participante. A audiogravação e/ou a videogravação serão utilizados apenas em contextos acadêmicos, não sendo divulgados publicamente.

Esclarecimentos: Todas as entrevistas serão sugeridas de ocorrer em datas e horários sugeridos pelo entrevistado, de modo a não prejudicar sua rotina. Ao final do estudo, o participante será informado sobre os resultados da pesquisa. Na ocorrência de qualquer dúvida a respeito da pesquisa, o participante tem liberdade para questionar e até mesmo se retirar da mesma, quando assim julgar conveniente. Este termo é feito em duas vias: uma do participante e outra da pesquisadora.

Benefícios: Com a sua participação, esperamos contribuir para o desenvolvimento científico acerca da relação de estudantes de Pedagogia com a escrita e assim sugerir contribuições para a formação de professores.

$\mathrm{Eu}$, de maneira livre, esclarecida e voluntária, concordo em participar da pesquisa acima explicitada. Estou ciente dos objetivos do estudo, dos procedimentos metodológicos, do assunto, das garantias de confidencialidade e da possibilidade de esclarecimentos permanentes sobre os mesmo. Estou ciente de que se trata de pesquisa de Mestrado em andamento do Programa de Pós Graduação em Educação da PUC-Rio. Está claro que minha participação é isenta de despesas e que minha imagem e meu nome não serão publicados sem minha prévia autorização por escrito. Estou de acordo com a videogravação e/ou audiogravação da entrevista a ser cedida para fins de registros acadêmicos. Estou ciente de que, em qualquer fase da pesquisa, tenho a liberdade de recusar a minha participação ou retirar meu consentimento, sem penalização alguma e sem nenhum prejuízo.

Nome do (a) entrevistado (a) e observado (a):

Email:

Telefone:

Número da identidade:

Autorizo, abaixo, a minha participação no estudo: "A relação de estudantes de Pedagogia com a escrita".

(Participante)

(Mestranda)

(Orientadora)

(Coorientadora)

Rio de Janeiro, , de de 2015 . 


\title{
Apêndice III - Questionário dos estudantes
}

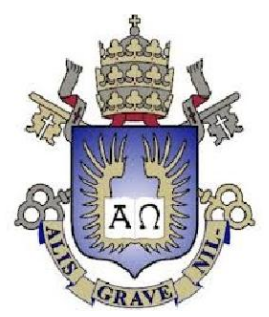

\author{
Pontifícia Universidade Católica do Rio de Janeiro \\ Departamento de Educação \\ Mestrado em Educação
}

Mestranda: Carolina Gonçalves de Almeida

Orientadora: Zena Eisenberg

Coorientadora: Erica dos Santos Rodrigues

\begin{abstract}
O presente questionário tem como objetivo fundamentar um estudo de cunho qualitativo que almeja identificar as relações dos estudantes de Pedagogia com a escrita, identificando, dentre vários aspectos, quais trabalhos o Curso de Pedagogia tem de enfatizar para melhor contribuir na formação do futuro professor.

As pesquisas que envolvem esse objeto são poucas e o tema é relativamente recente, necessitando de uma maior exploração teórica e empírica do assunto. Desse modo, sua participação nesta pesquisa é fundamental para o avanço do conhecimento científico na área da Educação. A pesquisa compromete-se com a não-identificação dos estudantes, apresentando-os em seu produto na forma fictícia, de modo em que todas as informações que sejam consideradas pertinentes possivelmente possibilitem a exposição sem nenhum prejuízo da pessoa física.
\end{abstract}

\section{Questionário para os estudantes}

\section{Identificação do período acadêmico do respondente:}

1- Assinale com um X em que rede de ensino você cursou o Ensino Fundamental e Ensino Médio:

\begin{tabular}{|c|c|c|c|}
\hline Nível x Rede & Privada & Pública & Misto \\
\hline Ensino Fundamental & & & \\
\hline Ensino Médio & & & \\
\hline
\end{tabular}


2- Atualmente, você está produzindo algum material escrito?
A. ( ) Sim.
B. ( ) Não.

3- Caso tenha assinalado a opção A na questão anterior, responda que tipo(s) de texto está escrevendo atualmente e por qual(is) motivo(s) (assinale quantas considerar necessário):

\begin{tabular}{|c|c|}
\hline Tipo de texto & $\mathrm{X}$ \\
\hline Artigo acadêmico & \\
\hline Blogs & \\
\hline Crônica & \\
\hline Diário & \\
\hline História em quadrinhos & \\
\hline Monografia & \\
\hline Poesia & \\
\hline Redes Sociais & \\
\hline Resenha crítica & \\
\hline Romance & \\
\hline Trabalho acadêmico & \\
\hline Outros: & \\
\hline
\end{tabular}

\begin{tabular}{|c|c|}
\hline Motivo & $\mathrm{x}$ \\
\hline Exigência acadêmica & \\
\hline Usufruto pessoal & \\
\hline Passatempo & \\
\hline Atividade de outro curso & \\
\hline Prática da escrita & \\
\hline Outros: \\
\end{tabular}

4- Você se considera um bom escritor (a)?
A. ( ) Sim.
B. ( ) Não.

Justifique sua resposta:

5- Em que medida a escola contribuiu para o domínio que você avalia ter da escrita?
A. ( ) A escola foi o principal fator.
B. ( ) A escola contribuiu, mas não foi o principal fator.
C. ( ) A escola contribuiu pouco.
D. ( ) A escola não contribuiu. 
6- Além da escola, o que mais pode ter contribuído? (Coloque em ordem de importância, sendo o número 1 o mais importante.)
A. ( ) Leitura.
B. ( ) Ambiente familiar.
C. ( ) Outras atividades culturais.
D. ( ) Outro:

7- Essa é a sua única graduação ou você possui outra?
A. ( ) Pedagogia - única graduação.
B. ( ) Outra:

8- Em que lugar você situaria a importância da escrita para a prática docente?

C. ( ) É o aspecto mais importante para exercer a profissão.

D. ( ) Está entre os aspectos mais importantes para exercer a profissão.

E. ( ) Está entre os aspectos pouco importantes para exercer a profissão.

F. ( ) É o menos importante.

9- Você considera que os docentes do Curso de Pedagogia estão qualificados para atuar na intervenção da escrita de seus alunos?

A- ( ) Sim, e eles atuam.

B- ( ) Sim, mas eles não atuam.

C- ( ) Não e eles atuam.

D- ( ) Não e eles não atuam.

Justifique

10- Você acredita que hoje está qualificado(a) para atuar na intervenção da escrita de crianças que estão nas séries iniciais do Ensino Fundamental, que estão tendo seu "primeiro" contato formal com o sistema de escrita alfabética?
A. ( ) Sim.
B. ( ) Não. 
12- As práticas destacadas acima fazem referência à maioria ou a um grupo pequeno de docentes? Explique objetivamente, citando exemplos de um ou mais professores e destacando uma prática que tenha sido significativa para você.

A. ( ) Maioria dos professores

B. ( ) Poucos professores.

13- Você considera que o atual currículo do curso de Pedagogia (distribuição das disciplinas e cursos oferecidos) da PUC-Rio é suficiente para auxiliar alunos que possuem dificuldades na escrita?
A. ( ) Sim.

B. ( ) Não.

Justifique sua resposta:

14- $\mathrm{O}$ que pode ser feito para ajudar estudantes que possuem problemas na escrita? Marque até duas opções, indicando com o número 1 a mais importante e com o número $\underline{2}$ a segunda mais importante.
A. ( ) Um acompanhamento individualizado com o professor fora do horário de aula.
B. ( ) Criação de espaços específicos, com profissionais especializados para atender à demanda de alunos que querem um apoio extracurricular.
C. ( ) Inclusão de uma disciplina obrigatória por semestre no currículo.
D. ( ) Outro:

15- Como você avalia sua escrita em relação ao domínio da norma padrão?
A. ( ) Domínio pleno.
B. ( ) Acima da média, mas tenho dúvidas pontuais. 

C. ( ) Dentro da média.
D. ( ) Abaixo da média, pois tenho dúvidas sistemáticas.
E. ( ) Domínio precário.

16- Quais são os seus maiores problemas na produção escrita? Marque quantas opções considerar necessárias.
A. ( ) Organização de ideias no texto.
B. ( ) Concordância verbal e nominal.
C. ( ) Crase.
D. ( ) Ortografia.
E. ( ) Regência verbal.
F. ( ) Pontuação.
G. ( ) Outros:

17- Sobre o seu processo de escrita de um texto, marque quais são suas práticas:

\begin{tabular}{|l|l|l|l|l|l|}
\hline Prática & Nunca & Raramente & Às Vezes & Frequentemente & Sempre \\
\hline sa seu trabalho/texto & & & & & \\
ide entregar. & & & & & \\
ita a um colega para & & & & \\
ar seu texto. & & & & \\
isa do auxílio de & & & & \\
na pessoa para & & & & \\
a a apoir pam para a & & & & \\
intrução do texto em sites & & & & & \\
\hline
\end{tabular}

\section{(pergunta específica para alunos da disciplina optativa)}

18- Por que você se inscreveu na disciplina optativa xxxxxxxxx?
A. ( ) Porque um professor indicou a disciplina.
B. ( ) Porque a coordenação sugeriu minha inscrição na disciplina.
C. ( ) Porque sinto necessidade de maior apoio para a minha escrita.
D. ( ) Porque quero acompanhar um(a) colega.
E. ( ) Porque acredito na relevância do assunto para um curso de formação de professores.
F. ( ) Outro: 


\title{
Apêndice IV - Roteiro de entrevista com os alunos
}

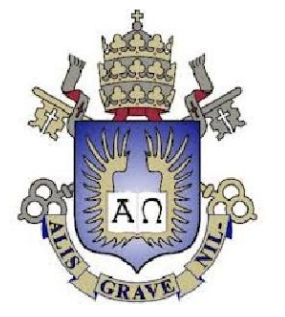

\author{
Pontifícia Universidade Católica do Rio de Janeiro \\ Departamento de Educação \\ Mestrado em Educação
}

Mestranda: Carolina Gonçalves de Almeida

Orientadora: Zena Eisenberg

Coorientadora: Erica dos Santos Rodrigues

\section{Roteiro de entrevista coletiva com os alunos}

\section{Condições:}

- Realizar ao final do curso, para contrapor ao questionário inicialmente respondido.

- Realizar sem a presença do docente da turma.

- Realizar durante um período da aula, em momento previamente combinado com o professor, a fim de que todos os alunos matriculados participem.

- Realizar a entrevista com a utilização de um gravador de voz e/ou videogravação.

\section{Questões:}

1- O que vocês acharam da disciplina?

foi difícil ou foi fácil;

foi cansativa;

foi construtiva, auxiliando realmente nos processos de leitura e escrita;

2- Quando vocês iniciaram a disciplina, uns disseram que vieram por indicação, outros por vontade própria, por necessidade. E agora, com a conclusão da disciplina, o que vocês acharam do curso: foi proveitoso ou não; vocês se 
arrependem, querem mais, acham que precisam de mais uma disciplina com a mesma proposta?

(Nesse momento, pedir aos alunos que, antes de responderem, identifiquem o motivo de inscrição na disciplina, para que se possa ao final cruzar respostas).

3- Quais foram os aspectos mais significativos que aprenderam: pontuação, ortografia, regência, construção clara de frases?

4- E por que vocês acham que antes não sabiam? Quais eram as suas dificuldades?

5- A disciplina correspondeu às suas expectativas:

- o que poderia ter sido retirado;

- o que precisa ser incluído;

6- O que vocês acharam da professora: ela é dinâmica? Sabe conduzir bem a aula? Esclarece todas as suas dúvidas? Alguma vez ela já deixou alguma dúvida sem resposta? Que tipo?

7- E como vocês se autoavaliam depois de cursar essa disciplina? Houve progresso na produção escrita? Como vocês percebem se houve ou não progresso?

8- Se vocês gostaram da disciplina, indicaram para outro colega cursá-la? Por quê? Por ser uma disciplina fácil e contar mais créditos ou por ser realmente uma disciplina importante?

9- Os professores das demais disciplinas perceberam o progresso de vocês? Como eles manifestaram essa percepção: eles elogiaram? Como?

10- Os professores demonstram interesse em saber como vocês estão nessa disciplina? Como? 


\title{
Apêndice V - Roteiro de entrevista com os professores das disciplinas específicas
}

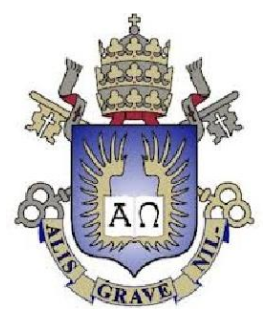

\author{
Pontifícia Universidade Católica do Rio de Janeiro \\ Departamento de Educação \\ Mestrado em Educação
}

Mestranda: Carolina Gonçalves de Almeida

Orientadora: Zena Eisenberg

Coorientadora: Erica dos Santos Rodrigues

\section{Roteiro de entrevista com os professores das disciplinas específicas}

\section{Condições:}

- Realizar a entrevista com a utilização de um gravador de voz e/ou videogravação.

\section{Questões:}

1- Qual a sua formação:

- Graduação

- Mestrado

- Doutorado

- Outros

2- Você já lecionou esse curso antes? Como você avalia sua experiência? Quais os problemas que você já enfrentou?

3- Por que você leciona essa disciplina: você solicitou ou foi indicado? Quais são as demandas que essa disciplina coloca para o professor que a leciona? (Quais as demandas que você acredita que essa disciplina traz para o professor?)

4- Você acredita que a escrita é importante? Quando? E para um curso de formação de professores?

5- Quais são seus principais objetivos com a disciplina? O que você pretende que o aluno alcance? Quais tipos de metodologias você utiliza? Para quais dessas metodologias você consegue perceber uma maior e melhor receptividade por parte dos estudantes? 
6- Por que você acha que os alunos estão cursando a disciplina? (Você percebe o interesse dos alunos ou tem a sensação de que eles estão cursando a disciplina apenas por obrigação, para cumprir créditos ou qualquer outro motivo que não seja o aprimoramento pessoal, acadêmico e profissional?)

7- Quando você vai trabalhar nestas disciplinas, que são relacionadas à produção escrita, como você atua para compreender quais são as dificuldades dos alunos?

8- Quais são os principais problemas que você observa na produção escrita de seus alunos? Quais tipos de questões/problemas você observa: apenas aspectos gramaticais, o conteúdo do texto, erros de ortografia... ?

9- Como você classificaria os problemas de produção escrita em geral dos estudantes em termos de grau de frequência e gravidade?

(alta - média - baixa)

10- Você corrige a produção textual dos alunos? Quais aspectos você corrige? Como faz a correção?

11-Que outras formas de intervenção você considera serem necessárias ou relevantes para atuar no processo de melhoria na produção escrita dos alunos?

12- Você acredita que essa disciplina (optativa) que você leciona é necessária? Por quê? Um semestre é suficiente para auxiliar os alunos ? Ou você acredita que a duração deveria ser maior? Você acredita que ela deveria ser incorporada à grade curricular obrigatória?

13-Durante um semestre letivo de acompanhamento, você percebe mudanças, progressos ou não-progressos nos alunos? De que forma? Pode citar um exemplo?

14- Como você compararia o desempenho dos estudantes de Pedagogia com os de outros cursos? Em que eles se assemelham e em que divergem? 
15- Ao observar a grade curricular do Curso de Pedagogia (a atual e a antiga ambas vigentes), você acredita que a atual distribuição de disciplinas é suficiente para auxiliar os alunos que demandam apoio nas atividades de escrita?

16-Quais medidas/trabalhos você poderia propor para que o curso complementasse (caso seja insuficiente) ou incrementasse (caso considere o currículo plenamente positivo) a área de produção escrita?

(Uma orientação qualificada por parte dos professores; Criação de espaços específicos, com profissionais especializados para atender à demanda de alunos que querem um apoio extracurricular, independentemente de obrigação, constituindo-se como um ambiente de participação espontânea e de livre acesso; Inclusão de uma disciplina obrigatória por semestre no currículo com a finalidade de trabalhar os mais diversos aspectos da produção escrita em seus mais diferentes níveis.) 


\title{
Apêndice VI - Roteiro de entrevista com os professores do curso de
} Pedagogia

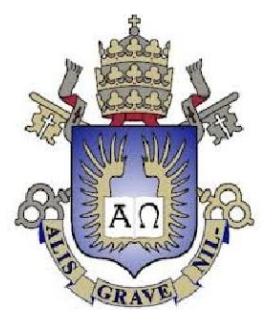

\author{
Pontifícia Universidade Católica do Rio de Janeiro \\ Departamento de Educação \\ Mestrado em Educação
}

Mestranda: Carolina Gonçalves de Almeida

Orientadora: Zena Eisenberg

Coorientadora: Erica dos Santos Rodrigues

\section{Roteiro de entrevista com professores do Curso de Pedagogia}

\section{Condições:}

- Realizar a entrevista com a utilização de um gravador de voz e/ou videogravação.

\section{Questões:}

1- Qual a sua formação:

- Graduação

- Mestrado

- Doutorado

- Outros

2- Por que você leciona essa disciplina: você solicitou ou foi indicado? Quais são as demandas que essa disciplina exige para o professor que a leciona?

3- Quais as demandas que você acredita que essa disciplina traz para o professor?

4- Você acredita que a escrita é importante? Quando? E para um curso de formação de professores? 
5- Apesar de não ser uma disciplina direcionada apenas para a escrita, você acredita que esse aspecto deve ser minuciosamente tratado nas aulas ou não? Qual seria a relação que você estabeleceria entre a disciplina que leciona e a escrita?

6- Quais são seus principais objetivos com a disciplina? O que você pretende que o aluno alcance? Quais tipos de metodologias você utiliza? Quais dessas metodologias você consegue perceber uma maior e melhor receptividade por parte dos estudantes?

7- Por que você acha que os alunos estão cursando a disciplina? (Você percebe o interesse dos alunos ou tem a sensação de que eles estão cursando a disciplina apenas por obrigação, para cumprir créditos ou qualquer outro motivo que não seja o aprimoramento pessoal, acadêmico e profissional?)

8- Quando trabalha na disciplina questões que são relacionadas à produção escrita? Como você atua para compreender quais são as dificuldades dos alunos?

9- Quais são os principais problemas que você observa? Quais tipos de questões/problemas você observa: apenas aspectos gramaticais, o conteúdo do texto, erros de ortografia...?

10- Como você classificaria os problemas de produção escrita em geral dos estudantes em termos de grau de frequência e gravidade?

(alta - média - baixa)

11- Você corrige a produção textual dos alunos? Quais aspectos você corrige? Como faz a correção?

12-Que outras formas de intervenção você considera serem necessárias ou relevantes para atuar na intervenção no processo de melhoria na produção escrita dos alunos? 
13- Você acredita que seu trabalho realizado no Curso, mesmo não estando diretamente relacionado à produção escrita, ajuda os alunos? Por quê ? (Caso o professor indique que realize ações nesse sentido)

17- Ao observar a grade curricular do Curso de Pedagogia (a atual e a antiga ambas vigentes), você acredita que a atual distribuição de disciplinas é suficiente para auxiliar os alunos que demandam apoio nas atividades de “aprender a escrever"?

14- Quais medidas/trabalhos você poderia propor para que o curso auxiliasse (caso seja insuficiente) ou incrementasse (caso considere o currículo plenamente positivo) na área de produção escrita?

(Uma orientação qualificada por parte dos professores; Criação de espaços específicos, com profissionais especializados para atender à demanda de alunos que querem um apoio extracurricular, independentemente de obrigação, constituindo-se como um ambiente de participação espontânea e de livre acesso; Inclusão de uma disciplina obrigatória por semestre no currículo com a finalidade de trabalhar os mais diversos aspectos da produção escrita em seus mais diferentes níveis.) 


\section{Apêndice VII - Manual de códigos do Atlas Ti}

\section{Famílias de códigos}

* Autoavaliação em relação a escrita; * Avaliação da disciplina; * Avaliação do professor; * Críticas das estudantes; * O que aprenderam na disciplina; * Relação com a Ed. Básica; * Relação com outros profs; A importância da escrita; Avaliação da disciplina eletiva pelos profs; Comparação com outras licenciaturas; Concepção de escrita; CORREÇÃO - como; CORREÇÃO - o que; Currículo; Dificuldades de autoria; Dificuldades de organização; Dificuldades em conceitos; Dificuldades Gramaticais; Influência da tecnologia; Melhores metodologias; Metodologias das Disciplinas Específicas; Objetivos das disciplinas específicas; Outras sugestões; Papel da universidade; Percepção de progressos; Perfil dos estudantes; Qnd e onde trb com a escrita; Quantidade de alunos; Relação com a Ed Basica; Relação Disciplina x Escrita; Relação Leitura x Escrita

\begin{tabular}{|c|c|l|}
\hline Código & Descrição & \multicolumn{1}{|c|}{ Exemplo } \\
\hline $\begin{array}{c}\text { Escrita na } \\
\text { sociedade }\end{array}$ & $\begin{array}{c}\text { Definição de } \\
\text { quando/porque a } \\
\text { escrita é importante }\end{array}$ & $\begin{array}{l}\text { A escrita é importante na sociedade, mas para um } \\
\text { professor é imprescindivel. }\end{array}$ \\
\hline $\begin{array}{c}\text { Imprescindível } \\
\text { para o professor }\end{array}$ & $\begin{array}{c}\text { Importância da } \\
\text { escrita para um curso } \\
\text { de formação de } \\
\text { professores }\end{array}$ & $\begin{array}{l}\text { Considero isso muito importante para a formação de } \\
\text { qualquer pessoa, qualquer área, mas especificamente } \\
\text { o professor, porque como essa pessoa vai ajudar } \\
\text { outros a fazerem isso se eles não conseguem fazer. }\end{array}$ \\
\hline $\begin{array}{c}\text { O professor tem } \\
\text { q dominar }\end{array}$ & $\begin{array}{c}\text { Importância do } \\
\text { domínio da escrita } \\
\text { pelo professor }\end{array}$ & eu não ensino aquilo que eu não sei. \\
\hline $\begin{array}{c}\text { É importante em } \\
\text { qualquer } \\
\text { circunstância }\end{array}$ & $\begin{array}{c}\text { Importância da } \\
\text { escrita para um curso } \\
\text { de formação de } \\
\text { professores }\end{array}$ & $\begin{array}{l}\text { E a escrita é importante em qualquer circunstância, } \\
\text { especialmente a escrita de professores. }\end{array}$ \\
\hline $\begin{array}{c}\text { É importante } \\
\text { para aprender o } \\
\text { formal }\end{array}$ & $\begin{array}{c}\text { Importância da } \\
\text { escrita para um curso } \\
\text { de formação de } \\
\text { professores }\end{array}$ & $\begin{array}{l}\text { Eu acho muito importante como aprender a } \\
\text { comunicar-se em uma linguagem formal, e eles estão } \\
\text { em uma universidade, eles participam do mundo } \\
\text { acadêmico, eles têm que saber escrever um português } \\
\text { correto. }\end{array}$ \\
\hline $\begin{array}{c}\text { A escrita é } \\
\text { importante, mas } \\
\text { a leitura } \\
\text { também }\end{array}$ & $\begin{array}{c}\text { Importância da } \\
\text { escrita para um curso } \\
\text { de formação de } \\
\text { professores }\end{array}$ & $\begin{array}{l}\text { Eu acho que ela é importantíssima, agora será que a } \\
\text { leitura é importante no curso de formação de } \\
\text { professores, porque eu acho que a leitura e a escrita } \\
\text { elas caminham juntas, então eu acho importante } \\
\text { pensar assim 'você, professora, é uma leitora? }\end{array}$ \\
\hline $\begin{array}{c}\text { Correção de } \\
\text { conteúdo e } \\
\text { forma }\end{array}$ & $\begin{array}{c}\text { Modo pelo qual o } \\
\text { professor relaciona } \\
\text { sua disciplina à }\end{array}$ & $\begin{array}{l}\text { Olha, o que eu faço em geral, eu corrijo os trabalhos } \\
\text { todos, corrijo a forma e corrijo o conteúdo, eu não } \\
\text { faço uma avaliação apenas do conteúdo do trabalho, }\end{array}$ \\
\hline
\end{tabular}




\begin{tabular}{|c|c|c|}
\hline & $\begin{array}{l}\text { escrita: correção de } \\
\text { aspectos conceituais } \\
\text { e da língua }\end{array}$ & $\begin{array}{l}\text { se eles aplicaram o conceito correto, fizeram } \\
\text { aplicação do conceito, da lei ou do que for, da política } \\
\text { da forma adequada. }\end{array}$ \\
\hline $\begin{array}{l}\text { Clareza na } \\
\text { transmissão de } \\
\quad \text { ideias }\end{array}$ & $\begin{array}{l}\text { Modo pelo qual o } \\
\text { professor relaciona } \\
\text { sua disciplina à } \\
\text { escrita: clareza nas } \\
\text { ideias dos alunos } \\
\end{array}$ & $\begin{array}{l}\text { Trabalho no sentido que uma das minhas questões é } \\
\text { que o pensamento, as conclusões das pessoas, as } \\
\text { ideias estejam claras, que eu consiga compreender a } \\
\text { partir da escrita a mensagem que eles tentaram } \\
\text { transmitir. }\end{array}$ \\
\hline $\begin{array}{l}\text { Não pode existir } \\
\text { erro }\end{array}$ & $\begin{array}{l}\text { Modo pelo qual o } \\
\text { professor relaciona } \\
\text { sua disciplina à } \\
\text { escrita: não pode } \\
\text { existir erro }\end{array}$ & $\begin{array}{l}\text { Se eles desenvolvem midias para serem apresentadas } \\
\text { para o grande público, como eles vão apresentar erro } \\
\text { de português?! Uma coisa é a fala informal, outra } \\
\text { coisa é a língua escrita. }\end{array}$ \\
\hline Não tem prova & $\begin{array}{l}\text { Modo pelo qual o } \\
\text { professor relaciona } \\
\text { sua disciplina à } \\
\text { escrita: não há provas }\end{array}$ & $\begin{array}{l}\text { Eu nunca faço prova escrita, não tem esse espaço da } \\
\text { escrita como uma prova, mas eu tento, ao longo do } \\
\text { curso, sempre dar um espaço de escrita, procurar dar } \\
\text { um espaço de escrita. }\end{array}$ \\
\hline $\begin{array}{l}\text { Moodle ajuda a } \\
\text { continuar o } \\
\text { trabalho }\end{array}$ & $\begin{array}{l}\text { Modo pelo qual o } \\
\text { professor relaciona } \\
\text { sua disciplina à } \\
\text { escrita: auxílio de } \\
\text { ferramentas online } \\
\end{array}$ & $\begin{array}{l}\text { O moodle é um lugar mais, digamos assim, mais } \\
\text { comum de trabalho das minhas turmas porque é uma } \\
\text { forma de a gente continuar debates que a gente não } \\
\text { teve tempo durante as aulas de concluir }\end{array}$ \\
\hline $\begin{array}{l}\text { Sempre tem } \\
\text { trabalho escrito }\end{array}$ & $\begin{array}{l}\text { Modo pelo qual o } \\
\text { professor relaciona } \\
\text { sua disciplina à } \\
\text { escrita: sempre } \\
\text { realiza trabalhos } \\
\text { escritos. }\end{array}$ & $\begin{array}{l}\text { Olha, o tema da escrita eu acho que pode ser } \\
\text { trabalhado em qualquer disciplina, ainda mais com } \\
\text { formação de professores, então assim eu faço, todos } \\
\text { esses trabalhos que eu estou te dizendo, sempre } \\
\text { terminam em um registro escrito. }\end{array}$ \\
\hline $\begin{array}{c}\text { Escrita na } \\
\text { avaliação }\end{array}$ & $\begin{array}{l}\text { Modo pelo qual o } \\
\text { professor relaciona } \\
\text { sua disciplina à } \\
\text { escrita: através de } \\
\text { trabalhos escritos } \\
\end{array}$ & $\begin{array}{l}\text { Tem obviamente os momentos de avaliação. Eu fiz esse } \\
\text { semestre, elas fizeram dois trabalhos xxx, dois } \\
\text { trabalhos para oxxx. No gl a gente teve um trabalho } \\
\text { que foi escrito e um trabalho que foi oral. Agora no } \\
\text { yyy os dois trabalhos foram escritos e orais [...] }\end{array}$ \\
\hline $\begin{array}{l}\text { Registro escrito } \\
\text { de dinâmicas e } \\
\text { ideias }\end{array}$ & $\begin{array}{l}\text { Modo pelo qual o } \\
\text { professor relaciona } \\
\text { sua disciplina à } \\
\text { escrita: registro } \\
\text { diário de ideias } \\
\end{array}$ & $\begin{array}{l}\text { Além disso, durante as aulas, muitas dessas dinâmicas } \\
\text { que eu te falei que algumas vezes eu consigo levar a } \\
\text { diante, outras vezes não, muitas vezes o registro } \\
\text { escrito é importante nesses momentos. Registro de } \\
\text { ideias, de pontos principais do texto. }\end{array}$ \\
\hline $\begin{array}{l}\text { Faz parte da } \\
\quad \text { rotina }\end{array}$ & $\begin{array}{l}\text { Modo pelo qual o } \\
\text { professor relaciona } \\
\text { sua disciplina à } \\
\text { escrita: faz parte da } \\
\text { rotina acadêmica }\end{array}$ & $\begin{array}{l}\text { Faz parte da rotina das minhas disciplinas, eu não } \\
\text { estou trabalhando com gramática, mas to trabalhando } \\
\text { com outros aspectos de leitura e escrita mais } \\
\text { sofisticados, mas é possivel integrar isso. }\end{array}$ \\
\hline $\begin{array}{l}\text { Corrigir e } \\
\text { comentar }\end{array}$ & $\begin{array}{l}\text { Modo pelo qual o } \\
\text { professor relaciona } \\
\text { sua disciplina à } \\
\text { escrita: o professor } \\
\text { tem que corrigir e }\end{array}$ & $\begin{array}{l}\text { Não na aula, ele vai corrigindo o trabalho e comenta } \\
\text { em aula os problemas da turma. }\end{array}$ \\
\hline
\end{tabular}




\begin{tabular}{|c|c|c|}
\hline & $\begin{array}{c}\text { comentar durante a } \\
\text { aula }\end{array}$ & \\
\hline $\begin{array}{l}\text { Tem que ter } \\
\text { tempo }\end{array}$ & $\begin{array}{l}\text { Modo pelo qual o } \\
\text { professor relaciona } \\
\text { sua disciplina à } \\
\text { escrita: é preciso } \\
\text { tempo }\end{array}$ & $\begin{array}{l}\text { O tempo é uma desculpa, eu acho que se a gente } \\
\text { abraça essa questão da leitura e da escrita, e acho que } \\
\text { isso é importante, a gente precisa dedicar um tempo } \\
\text { também para isso. }\end{array}$ \\
\hline $\begin{array}{c}\text { Escrita como } \\
\text { transmissão de } \\
\text { pensamento } \\
\end{array}$ & Concepção de escrita & $\begin{array}{l}\text { E acredito, e acho pela experiência que eu tenho com } \\
\text { isso, que a escrita me ajuda a estruturar meu } \\
\text { pensamento. }\end{array}$ \\
\hline $\begin{array}{l}\text { Escrita como } \\
\text { argumentação }\end{array}$ & Concepção de escrita & $\begin{array}{l}\text { [...]eu tô muito preocupado com organização do } \\
\text { trabalho, encaminhamento do trabalho, de discussão, } \\
\text { de argumento, se eles têm ou não têm um argumento. }\end{array}$ \\
\hline Escrita formal & $\begin{array}{l}\text { Concepção de } \\
\text { escrita: os estudantes } \\
\text { têm que aprender o } \\
\text { formal }\end{array}$ & $\begin{array}{l}\text { Bom, eu acho que a resposta meio que óbvia de cara } \\
\text { seria a questão da produção dos próprios textos e } \\
\text { trabalhos que elas têm que fazer, mas eu acho que a } \\
\text { escrita é muito mais do que isso. }\end{array}$ \\
\hline $\begin{array}{l}\text { Escrita com } \\
\text { prazer }\end{array}$ & $\begin{array}{l}\text { Concepção de } \\
\text { escrita: o estudante } \\
\text { precisa encontrar } \\
\text { prazer na escrita }\end{array}$ & $\begin{array}{l}{[. . .] \text { e acho que tem um segundo aspecto que é esse de }} \\
\text { encontrar na escrita um certo prazer }\end{array}$ \\
\hline $\begin{array}{c}\text { Escrita como } \\
\text { poder }\end{array}$ & Concepção de escrita & [...] a leitura e a escrita são instrumentos de poder \\
\hline $\begin{array}{l}\text { Escrita como } \\
\text { processo } \\
\text { cognitivo } \\
\end{array}$ & Concepção de escrita & $\begin{array}{l}\text { Ela é importante inclusive estruturalmente, porque ela } \\
\text { compõe estruturas cognitivas, ela compõe o processo } \\
\text { cognitivo. }\end{array}$ \\
\hline $\begin{array}{l}\text { Escrita como } \\
\text { comunicação }\end{array}$ & Concepção de escrita & $\begin{array}{l}\text { Ela precisa comunicar claramente isso e, para um } \\
\text { futuro professor, comunicar claramente é fundamental. }\end{array}$ \\
\hline $\begin{array}{l}\text { Especificidades } \\
\text { da escrita por } \\
\text { área }\end{array}$ & $\begin{array}{l}\text { Concepção de } \\
\text { escrita: cada área do } \\
\text { conhecimento tem } \\
\text { suas normas } \\
\end{array}$ & $\begin{array}{l}\text { [...] a minha exigência talvez seja um pouco diferente } \\
\text { dos outros professores nesse sentido. Acho que as } \\
\text { disciplinas têm as suas especificidades. }\end{array}$ \\
\hline $\begin{array}{l}\text { Escrita como } \\
\text { organização do } \\
\text { pensamento }\end{array}$ & Concepção de escrita & $\begin{array}{l}\text { [...] organizar seu pensamento em relação àquele tema } \\
\text { ou àquela leitura ou à discussão que está acontecendo } \\
\text { etc. }\end{array}$ \\
\hline $\begin{array}{l}\text { Escrita como } \\
\text { processo de } \\
\text { construção }\end{array}$ & Concepção de escrita & $\begin{array}{l}\text { A maior dificuldade, portanto é essa: fazer com que } \\
\text { eles entendam que fazer texto é um processo lento, de } \\
\text { construção, de idas e vindas, de consulta a materiais } \\
\text { diversos, manuais diversos. }\end{array}$ \\
\hline Escrever é difícil & Concepção de escrita & $\begin{array}{l}\text { Eu acho que a escrita é dificil, não acho que a escrita } \\
\text { seja uma tarefa assim espontânea, fácil [...]. }\end{array}$ \\
\hline $\begin{array}{l}\text { Escrever não é } \\
\text { automático }\end{array}$ & $\begin{array}{l}\text { Concepção de } \\
\text { escrita: o processo de } \\
\text { escrita não é } \\
\text { automático }\end{array}$ & $\begin{array}{l}\text { Eu acho que mesmo para quem não vai fazer uma } \\
\text { carreira acadêmica, trabalhar mesmo em escola, é } \\
\text { importantíssimo você... com a escrita você também } \\
\text { trabalha a questão da sua argumentação, porque você } \\
\text { é obrigado a pensar para poder escrever, não é uma } \\
\text { coisa automática. }\end{array}$ \\
\hline Ed Básica & Relação com a & Os graduandos têm chegado com pouca experiência \\
\hline
\end{tabular}




\begin{tabular}{|c|c|c|}
\hline precária & $\begin{array}{l}\text { Educação Básica: } \\
\text { nível de } \\
\text { escolarização } \\
\text { precário }\end{array}$ & $\begin{array}{l}\text { em escrita, às vezes passam pela universidade sem } \\
\text { viver essa experiência e, muitas das vezes, chegarão às } \\
\text { escolas, onde lecionarão, sem saber como escrever. }\end{array}$ \\
\hline $\begin{array}{l}\text { A escola não } \\
\text { trabalha as } \\
\text { dificuldades }\end{array}$ & $\begin{array}{l}\text { Relação com a } \\
\text { Educação Básica: a } \\
\text { escola não trabalha } \\
\text { alguns aspectos } \\
\text { essenciais que o } \\
\text { aluno precisa saber }\end{array}$ & $\begin{array}{l}\text { [...] porque são problemas que não são resolvidos de } \\
\text { uma hora para outra [...] Então a dificuldade vem daí, } \\
\text { até porque também não é trabalhado, isso não é tão } \\
\text { bem trabalhado nas escolas em geral. }\end{array}$ \\
\hline $\begin{array}{l}\text { Proveniente do } \\
\text { Ensino Médio }\end{array}$ & $\begin{array}{l}\text { Relação com a } \\
\text { Educação Básica: as } \\
\text { dificuldades que os } \\
\text { alunos apresentam } \\
\text { são provenientes do } \\
\text { Ensino Médio }\end{array}$ & $\begin{array}{l}\dot{E} \text { proveniente do ensino médio }[\ldots] \text { O culpado } \\
\text { principalmente é o sistema de avaliação que cobra } \\
\text { esse tipo de resposta do aluno. }\end{array}$ \\
\hline $\begin{array}{l}\text { Escola pública } \\
\text { vagabunda }\end{array}$ & $\begin{array}{l}\text { Relação com a } \\
\text { Educação Básica: a } \\
\text { escola pública do } \\
\text { Brasil é de baixa } \\
\text { qualidade } \\
\end{array}$ & $\begin{array}{l}\text { [...] muita gente que vem dessa escola pública } \\
\text { vagabunda que está aí. }\end{array}$ \\
\hline $\begin{array}{l}\text { Educação } \\
\text { Universitária } \\
\text { não favorece }\end{array}$ & $\begin{array}{l}\text { Papel da } \\
\text { Universidade: a } \\
\text { universidade também } \\
\text { deixa lacunas na } \\
\text { formação do } \\
\text { graduando }\end{array}$ & $\begin{array}{l}\text { Os graduandos têm chegado com pouca experiência } \\
\text { em escrita, às vezes passam pela universidade sem } \\
\text { viver essa experiência[...] }\end{array}$ \\
\hline $\begin{array}{l}\text { Relação íntima } \\
\text { com a escrita }\end{array}$ & $\begin{array}{l}\text { Papel da } \\
\text { Universidade: é } \\
\text { preciso que a } \\
\text { universidade } \\
\text { promova uma relação } \\
\text { intima com a escrita }\end{array}$ & $\begin{array}{l}\text { Não tenho a menor dúvida de que os cursos de } \\
\text { formação de professores devem manter uma relação } \\
\text { intima com a escrita [...] é preciso que os cursos de } \\
\text { formação se atentem para a necessidade da escrita. }\end{array}$ \\
\hline $\begin{array}{l}\text { Leitura e escrita } \\
\text { se } \\
\text { complementam }\end{array}$ & $\begin{array}{l}\text { Relação da leitura } \\
\text { com a escrita: são } \\
\text { processos que se } \\
\text { complementam }\end{array}$ & $\begin{array}{l}\text { Mas é preciso que se evidencie que não dá para falar } \\
\text { estritamente de escrita sem falar de leitura. Ambas } \\
\text { devem caminhar juntas. }\end{array}$ \\
\hline Falta leitura & $\begin{array}{l}\text { Relação da leitura } \\
\text { com a escrita: falta } \\
\text { leitura no } \\
\text { desenvolvimento do } \\
\text { professor } \\
\end{array}$ & $\begin{array}{l}\text { Eu acho que ela é importantíssima, agora será que a } \\
\text { leitura é importante no curso de formação de } \\
\text { professores, porque eu acho que a leitura e a escrita } \\
\text { elas caminham juntas, então eu acho importante } \\
\text { pensar assim 'você, professora, é uma leitora?'. }\end{array}$ \\
\hline $\begin{array}{l}\text { Boa leitura } \\
\text { ajuda a boa } \\
\text { escrita } \\
\end{array}$ & $\begin{array}{l}\text { Relação da leitura } \\
\text { com a escrita }\end{array}$ & $\begin{array}{l}\text { E eu sempre digo que a boa leitura ajuda a boa escrita } \\
{[\ldots . .]}\end{array}$ \\
\hline $\begin{array}{c}\text { Leitura alimenta } \\
\text { a escrita }\end{array}$ & $\begin{array}{l}\text { Relação da leitura } \\
\text { com a escrita }\end{array}$ & $\begin{array}{l}\text { [...] a leitura alimenta a escrita, a leitura me ajuda a } \\
\text { ter repertório para escrever, me ajuda nas questôes } \\
\text { ortográficas, gramaticais e de estrutura, enfim, então }\end{array}$ \\
\hline
\end{tabular}




\begin{tabular}{|c|c|c|}
\hline & & $\begin{array}{l}\text { cuidar do tipo de leitura que eu ofereço pode fazer } \\
\text { parte disso. }\end{array}$ \\
\hline $\begin{array}{l}\text { Ler ajuda a } \\
\text { escrever }\end{array}$ & $\begin{array}{l}\text { Relação da leitura } \\
\text { com a escrita }\end{array}$ & $\begin{array}{l}\text { Não adianta querer fazer escrever quem não tem o que } \\
\text { dizer. Lendo, o aluno, além de se informar, passa a ter } \\
\text { contato com estruturas complexas, bem organizadas. }\end{array}$ \\
\hline $\begin{array}{l}\text { Ampliação do } \\
\text { repertório } \\
\text { literário }\end{array}$ & $\begin{array}{l}\text { Objetivo da } \\
\text { disciplina específica: } \\
\text { ampliar repertório } \\
\text { cultural dos alunos }\end{array}$ & $\begin{array}{l}\text { Primeiro a ampliação de repertório. A primeira coisa } \\
\text { que eu pensei com a disciplina, elas precisam ampliar } \\
\text { o repertório literário. }\end{array}$ \\
\hline $\begin{array}{l}\text { Compreensão } \\
\text { das diferentes } \\
\text { linguagens }\end{array}$ & $\begin{array}{l}\text { Objetivo da } \\
\text { disciplina específica: } \\
\text { compreender } \\
\text { diferentes tipos de } \\
\text { linguagens }\end{array}$ & $\begin{array}{l}\text { Então meu trabalho com a escrita foi nesse sentido, } \\
\text { uma escrita diretamente ligada à estrutura de } \\
\text { linguagem dos textos com os quais eu estava } \\
\text { trabalhando, e buscando sempre nos textos didáticos } \\
\text { ou técnicos, elementos para pensar como se avalia a } \\
\text { qualidade disso. }\end{array}$ \\
\hline $\begin{array}{c}\text { Conhecer } \\
\text { diferentes } \\
\text { gêneros textuais }\end{array}$ & $\begin{array}{l}\text { Objetivo da } \\
\text { disciplina específica: } \\
\text { conhecer diferentes } \\
\text { gêneros textuais }\end{array}$ & $\begin{array}{l}\text { [...] dar ferramentas, conscientizar, principalmente, } \\
\text { conscientizar esses alunos que dentro da universidade } \\
\text { ele precisa lidar, trabalhar, produzir, ler gêneros } \\
\text { textuais [...]. }\end{array}$ \\
\hline $\begin{array}{l}\text { Ler e escrever } \\
\text { dinamicamente }\end{array}$ & $\begin{array}{l}\text { Objetivo da } \\
\text { disciplina específica: } \\
\text { permitir a liberdade } \\
\text { do aluno ler e } \\
\text { escrever }\end{array}$ & $\begin{array}{l}\text { [...] apresentar ao aluno um universo de leitura e } \\
\text { escrita que não fosse o usual, chato, cheio de regras. } \\
\text { Sendo mais claro, queriamos dar ao aluno } \\
\text { possibilidades de ler textos variados e, a partir deles, } \\
\text { construir um espaço para a expressão de ideias. }\end{array}$ \\
\hline $\begin{array}{c}\text { Gramática como } \\
\text { manual }\end{array}$ & $\begin{array}{l}\text { Objetivo da } \\
\text { disciplina específica: } \\
\text { apresentar a } \\
\text { gramática como um } \\
\text { manual } \\
\end{array}$ & $\begin{array}{l}\text { A gramática foi apresentada a eles como um manual } \\
\text { que deve ser consultado sempre que houver dúvidas, } \\
\text { assim como o dicionário. }\end{array}$ \\
\hline $\begin{array}{l}\text { Desenvolver a } \\
\text { autoria }\end{array}$ & $\begin{array}{c}\text { Objetivo da } \\
\text { disciplina específica: } \\
\text { promover a autoria } \\
\text { na criação dos textos }\end{array}$ & $\begin{array}{l}\text { Os alunos precisam ter conhecimento das múltiplas } \\
\text { ferramentas que podem auxiliá-los na melhoria de } \\
\text { seus textos. Basicamente o comando era: escreva sem } \\
\text { medo. }\end{array}$ \\
\hline $\begin{array}{l}\text { Possibilitar o } \\
\text { gosto pela } \\
\text { leitura }\end{array}$ & $\begin{array}{c}\text { Objetivo da } \\
\text { disciplina específica }\end{array}$ & $\begin{array}{l}\text { Como meta, queríamos que os alunos pudessem ler, } \\
\text { gostar da leitura, adquirir intimidade com essa } \\
\text { atividade vendo nela prazer }\end{array}$ \\
\hline $\begin{array}{l}\text { Moodle não } \\
\text { ajudou }\end{array}$ & $\begin{array}{l}\text { Metodologias das } \\
\text { disciplinas } \\
\text { específicas: o moodle } \\
\text { não ajudou no } \\
\text { desenvolvimento dos } \\
\text { trabalhos }\end{array}$ & $\begin{array}{l}\text { Quando era no Moodle, eu percebi que no Moodle foi } \\
\text { mais doloroso, porque eu corrigia no Moodle, e no } \\
\text { Moodle fica. }\end{array}$ \\
\hline Debates em sala & $\begin{array}{l}\text { Metodologias das } \\
\text { disciplinas } \\
\text { específicas }\end{array}$ & Fiz debates em sala [...] \\
\hline $\begin{array}{c}\text { Participação de } \\
\text { outros } \\
\text { professores } \\
\end{array}$ & $\begin{array}{l}\text { Metodologias das } \\
\text { disciplinas } \\
\text { específicas: }\end{array}$ & $\begin{array}{l}\text { [...] eu convidei uma pessoa que desse aula de } \\
\text { Educação Infantil e ela trouxe uma mala cheia de } \\
\text { livros, Educação Infantil não, Literatura Infantil [...]. }\end{array}$ \\
\hline
\end{tabular}




\begin{tabular}{|c|c|c|}
\hline & $\begin{array}{l}\text { participação de } \\
\text { professores de outras } \\
\text { áreas }\end{array}$ & \\
\hline Filmes & $\begin{array}{l}\text { Metodologias das } \\
\text { disciplinas } \\
\text { específicas }\end{array}$ & Vimos curta-metragens e vimos longa-metragens. \\
\hline $\begin{array}{l}\text { Internet como } \\
\text { ferramenta } \\
\text { diária }\end{array}$ & $\begin{array}{l}\text { Metodologias das } \\
\text { disciplinas } \\
\text { específicas: uso } \\
\text { constante da internet }\end{array}$ & $\begin{array}{l}\text { Assistimos vídeos de aulas, assistimos palestras } \\
\text { também nos vídeos. Usei a internet o tempo todo [...]. }\end{array}$ \\
\hline Diálogo & $\begin{array}{l}\text { Metodologias das } \\
\text { disciplinas } \\
\text { específicas: } \\
\text { conversas com os } \\
\text { alunos } \\
\end{array}$ & $\begin{array}{l}\text { A metodologia é muito diálogo, principalmente. Eu } \\
\text { converso muito com eles }\end{array}$ \\
\hline $\begin{array}{l}\text { Discussão- } \\
\text { reflexão }\end{array}$ & $\begin{array}{l}\text { Metodologias das } \\
\text { disciplinas } \\
\text { específicas: reflexões } \\
\text { sobre problemáticas }\end{array}$ & $\begin{array}{l}{[. . .] \text { outro ponto no meu método é fazer pensar, não }} \\
\text { existe uma resposta pronta, inclusive os problemas } \\
\text { gramaticais eu discuto com eles [...]. }\end{array}$ \\
\hline Uso de folhas & $\begin{array}{l}\text { Metodologias das } \\
\text { disciplinas } \\
\text { específicas: folhas } \\
\text { com } \\
\text { atividades/conteúdo }\end{array}$ & [...] folhas que eu levo para a sala de aula. \\
\hline $\begin{array}{c}\text { A tecnologia é } \\
\text { pouco necessária }\end{array}$ & $\begin{array}{l}\text { Metodologias das } \\
\text { disciplinas } \\
\text { específicas }\end{array}$ & $\begin{array}{l}\text { Uso, às vezes, recursos tecnológicos modernos, mas } \\
\text { não vejo necessidade. }\end{array}$ \\
\hline$\underset{\text { trbs }}{\text { Reescritura de }}$ & $\begin{array}{l}\text { Metodologias das } \\
\text { disciplinas } \\
\text { específicas }\end{array}$ & $\begin{array}{l}\text { E um caminho importante do nosso grupo todo é fazer } \\
\text { a reescritura, trabalhar o tempo todo com a correção } \\
\text { do texto que ele produziu. }\end{array}$ \\
\hline Diálogo & $\begin{array}{l}\text { Melhor metodologia } \\
\text { da disciplina } \\
\text { específica: diálogos } \\
\text { com alunos }\end{array}$ & $\begin{array}{l}\text { Eles têm melhor interesse no diálogo porque os } \\
\text { alunos, não só de Pedagogia, em geral os jovens } \\
\text { alunos, por todas essas tecnologias modernas, eles } \\
\text { rejeitam um pouco essa questão de..., eles estão muito } \\
\text { impacientes, eles estão muito apressados, então eles } \\
\text { até fazem, mas uma leitura mais densa, um texto mais } \\
\text { complexo eles rejeitam, e aí que a gente tem que entrar } \\
\text { com a sedução [...]. }\end{array}$ \\
\hline $\begin{array}{l}\text { Produção de } \\
\text { crônicas }\end{array}$ & $\begin{array}{l}\text { Metodologias das } \\
\text { disciplinas } \\
\text { específicas: atividade } \\
\text { de produzir crônicas }\end{array}$ & $\begin{array}{l}\text { O melhor de tudo que eu achei foram as crônicas, } \\
\text { porque a crônica tem uma coisa do cotidiano, da } \\
\text { experiência cotidiana, que é muito prazeroso de fazer. } \\
\text { Ficaram ótimas as crônicas delas. }\end{array}$ \\
\hline Debates e visitas & $\begin{array}{l}\text { Metodologias das } \\
\text { disciplinas } \\
\text { específicas: debates } \\
\text { em sala e visitas fora } \\
\text { da universidade }\end{array}$ & $\begin{array}{l}\text { Acho que os debates, momentos em que se podia abrir } \\
o \text { coração, falar das dúvidas e desejos, das } \\
\text { dificuldades foram muito bem recebidos. A ideia de ir } \\
\grave{a} \text { livraria, CCBB foi muito bem sucedida. Alguns } \\
\text { alunos nunca tinham ido a esses lugares e foi um } \\
\text { mundo novo que se abria. }\end{array}$ \\
\hline
\end{tabular}




\begin{tabular}{|c|c|c|}
\hline $\begin{array}{l}\text { Qualquer } \\
\text { disciplina pode } \\
\text { trabalhar com } \\
\text { escrita }\end{array}$ & $\begin{array}{l}\text { Todas as disciplinas } \\
\text { podem trabalhar com } \\
\text { questões de escrita }\end{array}$ & $\begin{array}{l}\text { Olha, o tema da escrita eu acho que pode ser } \\
\text { trabalhado em qualquer disciplina, ainda mais com } \\
\text { formação de professores, então assim eu faço, todos } \\
\text { esses trabalhos que eu estou te dizendo, sempre } \\
\text { terminam em um registro escrito. }\end{array}$ \\
\hline $\begin{array}{l}\text { Cotidiano } \\
\text { cansativo }\end{array}$ & Perfil dos estudantes & $\begin{array}{l}\text { O Moodle é bacana, a plataforma é bacana, mas pra } \\
\text { quem faz estágio, elas trabalham, todas as minhas } \\
\text { alunas trabalham, e fazem estágio, então trabalhar, } \\
\text { assistir aula e fazer estágio, e ainda chegar em casa e } \\
\text { conversar no Moodle, mandar o trabalho, comentar o } \\
\text { trabalho dos outros. }\end{array}$ \\
\hline $\begin{array}{c}\text { Alunas } \\
\text { iniciantes têm } \\
\text { maiores } \\
\text { dificuldades } \\
\end{array}$ & Perfil dos estudantes & $\begin{array}{l}\text { [...] você sente a diferença quando está na turma dos } \\
\text { primeiros períodos, a dificuldade acho que é maior. }\end{array}$ \\
\hline $\begin{array}{l}\text { Clientela das } \\
\text { camadas } \\
\text { populares }\end{array}$ & Perfil dos estudantes & $\begin{array}{l}\text { cada vez mais o pessoal que procura a carreira } \\
\text { docente é o pessoal que vem das camadas mais } \\
\text { populares, que vem da escola pública, que portanto } \\
\text { trás uma série de deficiências na sua formação básica. }\end{array}$ \\
\hline $\begin{array}{l}\text { Dificuldades de } \\
\text { expressão de } \\
\text { pensamento na } \\
\text { escrita } \\
\end{array}$ & $\begin{array}{l}\text { Dificuldade de } \\
\text { organização textual } \\
\text { que o professor } \\
\text { observa }\end{array}$ & $\begin{array}{l}\text { Mas o que eu senti mais foi isso, uma certa } \\
\text { dificuldade, porque elas se expressam bem oralmente, } \\
\text { então é uma certa dificuldade de expressão em lingua } \\
\text { escrita do pensamento. }\end{array}$ \\
\hline $\begin{array}{c}\text { Dificuldade } \\
\text { maior é } \\
\text { planejamento } \\
\text { textual }\end{array}$ & $\begin{array}{c}\text { Dificuldade de } \\
\text { organização textual } \\
\text { que o professor } \\
\text { observa }\end{array}$ & $\begin{array}{l}\text { a dificuldade maior é planejamento textual, mas isso é } \\
\text { comum em quase todos }\end{array}$ \\
\hline $\begin{array}{l}\text { Argumentação é } \\
\text { superficial }\end{array}$ & $\begin{array}{l}\text { Dificuldade de } \\
\text { organização textual } \\
\text { que o professor } \\
\text { observa: } \\
\text { argumentação } \\
\text { superficial } \\
\end{array}$ & $\begin{array}{l}\text { Então eles apresentam dificuldade de planejamento, de } \\
\text { argumentaçâo, argumentação superficial, por isso que } \\
\text { eu digo que precisaria de mais tempo, porque são } \\
\text { problemas que não são resolvidos de uma hora para } \\
\text { outra [...]. }\end{array}$ \\
\hline $\begin{array}{l}\text { Escrita como } \\
\text { processo de } \\
\text { construção }\end{array}$ & $\begin{array}{l}\text { Dificuldade de } \\
\text { organização textual } \\
\text { que o professor } \\
\text { observa: perceber a } \\
\text { escrita como } \\
\text { processo de } \\
\text { construção } \\
\end{array}$ & $\begin{array}{l}\text { A maior dificuldade, portanto é essa: fazer com que } \\
\text { eles entendam que fazer texto é um processo lento, de } \\
\text { construção, de idas e vindas, de consulta a materiais } \\
\text { diversos, manuais diversos... }\end{array}$ \\
\hline $\begin{array}{l}\text { Parágrafos } \\
\text { longos }\end{array}$ & $\begin{array}{l}\text { Dificuldade de } \\
\text { organização textual } \\
\text { que o professor } \\
\text { observa }\end{array}$ & $\begin{array}{l}\text { [...] às vezes são parágrafos muito longos e que, por } \\
\text { serem muito longos, o próprio autor se perde na ideia, } \\
\text { não chega a concluir, não chega a passar para o leitor } \\
\text { a ideia que ele está querendo registrar. }\end{array}$ \\
\hline $\begin{array}{l}\text { Textos } \\
\text { truncados }\end{array}$ & $\begin{array}{l}\text { Dificuldade de } \\
\text { organização textual } \\
\text { que o professor } \\
\text { observa }\end{array}$ & $\begin{array}{l}\text { Eu percebo a organização do texto, textos truncados, } \\
\text { às vezes textos com ideias repetidas, uma dificuldade } \\
\text { em relação à síntese. }\end{array}$ \\
\hline
\end{tabular}




\begin{tabular}{|c|c|c|}
\hline $\begin{array}{l}\text { Dificuldade de } \\
\text { composição }\end{array}$ & $\begin{array}{l}\text { Dificuldade de } \\
\text { organização textual } \\
\text { que o professor } \\
\text { observa: composição }\end{array}$ & $\begin{array}{l}\text { Mas é principalmente uma questão de como compor } \\
\text { isso. Quando eu exijo minimamente duas mil palavras } \\
\text { eles ficam loucos. Depois o problema que eles têm } \\
\text { depois de mostrar a fazer isso é como reduzir para } \\
\text { duas mil palavras, mas a reação inicial é 'eu nunca } \\
\text { vou conseguir escrever isso' porque eles não sabe } \\
\text { como compor uma coisa desse tipo. }\end{array}$ \\
\hline $\begin{array}{l}\text { Dificuldade de } \\
\text { expressão } \\
\text { escrita }\end{array}$ & $\begin{array}{l}\text { Dificuldade de } \\
\text { organização textual } \\
\text { que o professor } \\
\text { observa }\end{array}$ & $\begin{array}{l}\text { [...] é muito comum encontrar grande dificuldade de } \\
\text { expressão escrita nos alunos. }\end{array}$ \\
\hline $\begin{array}{l}\text { Construções } \\
\text { inadequadas }\end{array}$ & $\begin{array}{l}\text { Dificuldade de } \\
\text { organização textual } \\
\text { que o professor } \\
\text { observa }\end{array}$ & $\begin{array}{l}\text { [...] o que me incomodava era justamente essa questão } \\
\text { de não sabe citar, de repente, um autor de maneira } \\
\text { adequada. }\end{array}$ \\
\hline $\begin{array}{c}\text { Texto } \\
\text { desarticulado }\end{array}$ & $\begin{array}{c}\text { Dificuldade de } \\
\text { organização textual } \\
\text { que o professor } \\
\text { observa }\end{array}$ & $\begin{array}{l}\text { Eu acho assim o texto desarticulado, com saltos, com } \\
\text { rupturas do ponto de vista da estrutura do texto, não } \\
\text { tem uma unidade, acho que isso é um problema para } \\
\text { mim, é mais do que a regra. }\end{array}$ \\
\hline $\begin{array}{l}\text { Gramática é o } \\
\text { que mais } \\
\text { compromete }\end{array}$ & $\begin{array}{l}\text { Dificuldades } \\
\text { gramaticais que o } \\
\text { professor observa }\end{array}$ & $\begin{array}{l}\text { Eu acho que o aspecto gramatical é o que mais } \\
\text { compromete, que é a estrutura da frase, aspecto } \\
\text { gramatical nesse sentido, você conseguir construir } \\
\text { uma frase que efetivamente expresse seu pensamento } \\
\text { de maneira compreensivel, de maneira clara, de } \\
\text { maneira precisa. }\end{array}$ \\
\hline $\begin{array}{c}\text { Pontuação é } \\
\text { difícil }\end{array}$ & $\begin{array}{l}\text { Dificuldades } \\
\text { gramaticais que o } \\
\text { professor observa }\end{array}$ & [...] pontuação é dificil para eles. \\
\hline $\begin{array}{l}\text { Ortografia não é } \\
\text { um problema }\end{array}$ & $\begin{array}{c}\text { Dificuldades } \\
\text { gramaticais que o } \\
\text { professor observa: } \\
\text { ortografia não é } \\
\text { dificultosa } \\
\end{array}$ & $\begin{array}{l}\text { [...] nem vejo tanto hoje em dia dificuldade ortográfica } \\
\text { não, eles estão chegando com uma ortografia até bem } \\
\text { razoável. }\end{array}$ \\
\hline $\begin{array}{l}\text { Crase é muito } \\
\text { difícil }\end{array}$ & $\begin{array}{l}\text { Dificuldades } \\
\text { gramaticais que o } \\
\text { professor observa: } \\
\text { crase }\end{array}$ & $\begin{array}{l}\text { As crases são um problema generalizado, crase é uma } \\
\text { coisa muito difícil, é engraçado, mas isso acontece em } \\
\text { todos os níveis de formação, digamos assim, pelo } \\
\text { menos é o que eu tenho visto. }\end{array}$ \\
\hline $\begin{array}{c}\text { Erros de } \\
\text { concordância } \\
\text { são frequentes }\end{array}$ & $\begin{array}{l}\text { Dificuldades } \\
\text { gramaticais que o } \\
\text { professor observa: } \\
\text { concordância }\end{array}$ & $\begin{array}{l}\text { Também são erros de concordância, que também } \\
\text { existem, são bastante frequentes }\end{array}$ \\
\hline $\begin{array}{l}\text { Pontuação } \\
\text { inadequada }\end{array}$ & $\begin{array}{l}\text { Dificuldades } \\
\text { gramaticais que o } \\
\text { professor observa: } \\
\text { pontuação }\end{array}$ & $\begin{array}{l}\text { Erros de pontuação, que muda completamente o } \\
\text { sentido da frase. As vezes as frases são muito longas } \\
\text { por causa de erros de pontuação mesmo. }\end{array}$ \\
\hline $\begin{array}{l}\text { Erros } \\
\text { gramaticais } \\
\text { mesmo }\end{array}$ & $\begin{array}{l}\text { Dificuldades } \\
\text { gramaticais que o } \\
\text { professor observa: }\end{array}$ & $\begin{array}{l}\text { Gramaticais. Gramática, erro mesmo, na escrita. } \\
\text { Estou falando de coisa simples, mas que precisam ser } \\
\text { aprendidos, sujeito, predicado, concordância verbal, }\end{array}$ \\
\hline
\end{tabular}




\begin{tabular}{|c|c|c|}
\hline & $\begin{array}{l}\text { erros gramaticais } \\
\text { gerais }\end{array}$ & acento, erro muito mais nesse sentido. \\
\hline $\begin{array}{l}\text { Advérbio, } \\
\text { pontuação e } \\
\text { acento são } \\
\text { dificuldades }\end{array}$ & $\begin{array}{l}\text { Dificuldades } \\
\text { gramaticais que o } \\
\text { professor observa }\end{array}$ & $\begin{array}{l}\text { Saber o local correto do advérbio, utilização de } \\
\text { pontuação, saber aonde usa acento e não, no lugar de } \\
\text { eles usarem o 'que', eles usam o onde, o gerúndio. }\end{array}$ \\
\hline $\begin{array}{l}\text { Regras } \\
\text { gramaticais são } \\
\text { desconhecidas }\end{array}$ & $\begin{array}{l}\text { Dificuldades } \\
\text { gramaticais que o } \\
\text { professor observa }\end{array}$ & $\begin{array}{l}\text { Formulação ortográfica, concordâncias, acentos, } \\
\text { hífens, todas essas regras gramaticais. As regras } \\
\text { gramaticais são muito desconhecidas e tem muitas } \\
\text { dúvidas, onde colocar uma crase. }\end{array}$ \\
\hline $\begin{array}{l}\text { Erros } \\
\text { gramaticais } \\
\text { comuns }\end{array}$ & $\begin{array}{l}\text { Dificuldades } \\
\text { gramaticais que o } \\
\text { professor observa }\end{array}$ & $\begin{array}{l}\text { Com o uso de vírgula, por exemplo, então separar } \\
\text { sujeito e verbo com vírgula. O uso de conectivos, por } \\
\text { exemplo, ao invés de 'que', 'onde'. As vezes erros de } \\
\text { concordância, se o verbo estiver muito longe do sujeito } \\
\text { aí perde a noção da concordância. São os erros mais } \\
\text { comuns assim. }\end{array}$ \\
\hline $\begin{array}{l}\text { Dificuldade de } \\
\text { autoria }\end{array}$ & $\begin{array}{l}\text { Dificuldade de } \\
\text { autoria: os alunos } \\
\text { não conseguem } \\
\text { construir textos }\end{array}$ & $\begin{array}{l}\text { A tendência é tentar se esconder atrás do texto dos } \\
\text { outros. }\end{array}$ \\
\hline $\begin{array}{c}\text { Falta de clareza } \\
\text { nas ideias }\end{array}$ & $\begin{array}{c}\text { Dificuldades } \\
\text { conceituais }\end{array}$ & $\begin{array}{l}\text { [...] falta de clareza nas ideias, eu acho isso } \\
\text { preocupante }\end{array}$ \\
\hline $\begin{array}{c}\text { Citações } \\
\text { inadequadas }\end{array}$ & $\begin{array}{l}\text { Dificuldades } \\
\text { conceituais }\end{array}$ & $\begin{array}{l}\text { [...] o que me incomodava era justamente essa questão } \\
\text { de não sabe citar, de repente, um autor de maneira } \\
\text { adequada }\end{array}$ \\
\hline $\begin{array}{l}\text { Não articular } \\
\text { ideiais }\end{array}$ & $\begin{array}{c}\text { Dificuldades } \\
\text { conceituais: não } \\
\text { articular ideias de um } \\
\text { conteúdo } \\
\end{array}$ & $\begin{array}{l}\text { não conseguir estabelecer um diálogo entre os textos } \\
\text { num determinado momento, uma articulação entre os } \\
\text { textos }\end{array}$ \\
\hline $\begin{array}{l}\text { Vocabulário } \\
\text { fraco }\end{array}$ & $\begin{array}{l}\text { Dificuldades } \\
\text { conceituais: falta de } \\
\text { conhecimento } \\
\end{array}$ & $\begin{array}{l}\text { E, às vezes, vocabulário, dá para perceber que os } \\
\text { alunos lêem pouco. }\end{array}$ \\
\hline $\begin{array}{l}\text { Aulas } \\
\text { praticamente } \\
\text { particulares }\end{array}$ & $\begin{array}{l}\text { Quantidade de } \\
\text { estudantes: favorece } \\
\text { o trabalho }\end{array}$ & $\begin{array}{l}\text { Em um grupo de } 18 \text { alunos, é muito dificil traçar uma } \\
\text { média. Tivemos quase aulas particulares... e as } \\
\text { especificidades eram bastante diversas. Um tinha } \\
\text { problemas em pontuar, o outro com ortografia, outro } \\
\text { com a concatenação das ideias, outro com } \\
\text { pessoalidade ou impessoalidade... enfim... }\end{array}$ \\
\hline $\begin{array}{c}\text { Maior } \\
\text { acompanhament } \\
\text { o com poucos } \\
\text { alunos }\end{array}$ & $\begin{array}{l}\text { Quantidade de } \\
\text { estudantes: favorece } \\
\text { o trabalho }\end{array}$ & $\begin{array}{l}\text { [...] essa turma é uma turma pequena, são treze } \\
\text { alunos, então é uma turma bem pequenininha, eu acho } \\
\text { assim que tem uns três alunos que têm realmente uma } \\
\text { dificuldade grande de escrita. }\end{array}$ \\
\hline $\begin{array}{c}\text { Primeiros } \\
\text { períodos tem } \\
\text { mais } \\
\text { dificuldades } \\
\end{array}$ & $\begin{array}{l}\text { Perfil dos estudantes: } \\
\text { períodos iniciais são } \\
\text { mais difíceis }\end{array}$ & $\begin{array}{l}\text { Geralmente as pessoas estão ou no sétimo ou no oitavo } \\
\text { periodo, também isso é importante porque você sente a } \\
\text { diferença quanta está na turma dos primeiros } \\
\text { periodos, a dificuldade acho que é maior. }\end{array}$ \\
\hline Tecnologia & Influência da & Como eu trabalho muito pouco com a questão da \\
\hline
\end{tabular}




\begin{tabular}{|c|c|c|}
\hline ajuda os alunos & $\begin{array}{l}\text { tecnologia: ajuda os } \\
\text { estudantes }\end{array}$ & $\begin{array}{l}\text { escrita manual, hoje quase todos trazem o laptop, } \\
\text { pedem para imprimir, e como os computadores tem } \\
\text { corretor ortográfico, essa questão do ortográfico eu } \\
\text { não percebo muito não. }\end{array}$ \\
\hline $\begin{array}{l}\text { Os alunos } \\
\text { evoluem }\end{array}$ & $\begin{array}{l}\text { Percepção de } \\
\text { progressos: é } \\
\text { possível perceber } \\
\text { evolução nos } \\
\text { estudantes }\end{array}$ & $\begin{array}{l}\text { E eu percebo assim, esse grupo especificamente que } \\
\text { está tendo aula comigo esse semestre, eu tenho alunas } \\
\text { ali que já são minhas alunas há quatro semestres } \\
\text { seguidos [...] mas de alguma maneira eu percebi a } \\
\text { evolução ou não, e também nesse aspecto de } \\
\text { apropriação da língua e da escrita }\end{array}$ \\
\hline $\begin{array}{l}\text { Maior } \\
\text { acompanhament } \\
\text { o com poucos } \\
\text { alunos }\end{array}$ & $\begin{array}{l}\text { Percepção de } \\
\text { progressos: é } \\
\text { possível acompanhar } \\
\text { e perceber com } \\
\text { poucos alunos }\end{array}$ & $\begin{array}{l}\text { [...] são poucos alunos, então é possivel você também } \\
\text { acompanhar as pessoas, eles são seus alunos em } \\
\text { diferentes periodos, às vezes em diferentes disciplinas. } \\
\text { A turma que eu tô dando aula agora, várias pessoas já } \\
\text { foram meus alunos em outras disciplinas, então você } \\
\text { vai acompanhando, conhece as dificuldades daquela } \\
\text { pessoa então você já vai orientando ela em relação a } \\
\text { essas questões. }\end{array}$ \\
\hline $\begin{array}{l}\text { Progresso de } \\
\text { ampliação de } \\
\text { repertorio }\end{array}$ & $\begin{array}{l}\text { Percepção de } \\
\text { progressos: visível na } \\
\text { ampliação de } \\
\text { repertório cultural } \\
\text { dos estudantes } \\
\end{array}$ & $\begin{array}{l}\text { Primeiro porque esse era um tema como qual elas } \\
\text { jamais tinham lidado, literatura, gêneros literários } \\
\text { [...]. }\end{array}$ \\
\hline $\begin{array}{l}\text { A maioria } \\
\text { progride }\end{array}$ & $\begin{array}{l}\text { Percepção de } \\
\text { progressos }\end{array}$ & $\begin{array}{l}\text { Consigo, não vou dizer com todos, mas ai que eu digo, } \\
\text { eu comparo a primeira [...] redação [...], como é que } \\
\text { ele chegou aqui na minha mão, e esta redação eu } \\
\text { guardo e leio no final do curso, nós fazemos isso }\end{array}$ \\
\hline $\begin{array}{l}\text { Alunos mais } \\
\text { cuidadosos }\end{array}$ & $\begin{array}{l}\text { Percepção de } \\
\text { progressos: os } \\
\text { estudantes evoluem e } \\
\text { ficam mais } \\
\text { cuidadosos }\end{array}$ & $\begin{array}{l}\text { Vi muitos textos truncados, agarrados em vícios no } \\
\text { inicio. No fim do periodo vi textos mais leves, com } \\
\text { estilos próprios. Vi textos mais encadeados, com ideias } \\
\text { melhor organizadas. Houve mais cuidado com os } \\
\text { textos finais. Os alunos entenderam que deveriam } \\
\text { trabalhar nos próprios textos. Isso é um exemplo } \\
\text { importantíssimo! }\end{array}$ \\
\hline $\begin{array}{l}\text { Os alunos dão } \\
\text { retorno }\end{array}$ & $\begin{array}{l}\text { Percepção de } \\
\text { progressos: é } \\
\text { possível perceber } \\
\text { progressos quando } \\
\text { alunos dizem ter } \\
\text { saudades ou quando } \\
\text { passam em algum } \\
\text { concurso }\end{array}$ & $\begin{array}{l}\text { Eu acho que ajuda porque eu tenho tido assim algum } \\
\text { retorno, de alunos voltarem, eu acho até graça eles } \\
\text { falarem 'eu tenho saudade'. Ou o pessoal quando faz } \\
\text { concurso. Eu acho que há algum retorno dos alunos. }\end{array}$ \\
\hline $\begin{array}{l}\text { É difícil saber se } \\
\text { há progressos }\end{array}$ & $\begin{array}{l}\text { Percepção de } \\
\text { progressos: é difícil } \\
\text { avaliar a evolução da } \\
\text { escrita diante de } \\
\text { tantos outros } \\
\text { aspectos particulares }\end{array}$ & $\begin{array}{l}\text { Eu acredito que sim, mas eu nunca me dediquei a } \\
\text { avaliar isso especificamente, acho dificil conseguir } \\
\text { avaliar [...] eu não estou avaliando isso } \\
\text { especificamente, não estava interessada em avaliar } \\
\text { isso especificamente, embora eu ache interessante que } \\
\text { se avalie, não sei se sou eu, se são as outras coisas, }\end{array}$ \\
\hline
\end{tabular}




\begin{tabular}{|c|c|c|}
\hline & da disciplina & não sei separar o efeito do meu trabalho especifico. \\
\hline $\begin{array}{l}\text { É mais } \\
\text { perceptível } \\
\text { quando o tempo } \\
\text { é maior }\end{array}$ & $\begin{array}{l}\text { Percepção de } \\
\text { progressos: é } \\
\text { possível perceber } \\
\text { progressos na escrita } \\
\text { quando o professor } \\
\text { acompanha um } \\
\text { mesmo grupo } \\
\text { durante tempo maior }\end{array}$ & $\begin{array}{l}\text { Eu acredito que sim, mas eu nunca me dediquei a } \\
\text { avaliar isso especificamente, acho difícil conseguir } \\
\text { avaliar isso. Eu vejo às vezes, por exemplo, essa turma } \\
\text { que eu estou pegando agora em xxxx, ela foi minha } \\
\text { turma ano passado inteiro em xxxx, então esse é o } \\
\text { terceiro semestre que eu estou com a mesma turma } \\
\text { praticamente. Então, claro, ai eu consigo comparar, } \\
\text { ver uma evolução [...]. }\end{array}$ \\
\hline $\begin{array}{l}\text { Correção de } \\
\text { conteúdo e } \\
\text { forma }\end{array}$ & $\begin{array}{l}\text { O quê corrige: } \\
\text { conteúdo da matéria } \\
\text { e forma do trabalho }\end{array}$ & $\begin{array}{l}\text { Olha, o que eu faço em geral, eu corrijo os trabalhos } \\
\text { todos, corrijo a forma e corrijo o conteúdo, eu não } \\
\text { faço uma avaliação apenas do conteúdo do trabalho, } \\
\text { se eles aplicaram o conceito correto, fizeram } \\
\text { aplicação do conceito, da lei ou do que for, da politica } \\
\text { da forma adequada. }\end{array}$ \\
\hline $\begin{array}{l}\text { Correção de } \\
\text { aspectos } \\
\text { gramaticas }\end{array}$ & $\begin{array}{c}\text { O quê corrige: } \\
\text { aspectos gramaticais }\end{array}$ & $\begin{array}{l}\text { Eu leio cada linha, a cada linha que eu leio eu faço } \\
\text { uma marca que naquela linha tem algo que eu sugiro } \\
\text { em termos da escrita: um ponto, uma virgula, tem uma } \\
\text { crase. }\end{array}$ \\
\hline $\begin{array}{c}\text { Correção de } \\
\text { aspectos } \\
\text { organizacionais } \\
\end{array}$ & $\begin{array}{l}\text { O quê corrige: } \\
\text { aspectos } \\
\text { organizacionais }\end{array}$ & $\begin{array}{l}\text { [...] organização, mando refazer quando tá muito } \\
\text { truncado, mostro como poderia ter uma organização } \\
\text { melhor do texto, uma organização melhor das ideias. }\end{array}$ \\
\hline $\begin{array}{l}\text { Correção de } \\
\text { aspectos } \\
\text { conceituais }\end{array}$ & $\begin{array}{l}\text { O quê corrige: } \\
\text { aspectos conceituais }\end{array}$ & $\begin{array}{l}\text { Em geral, eu marco no primeiro texto, na primeira } \\
\text { edição, 'x' do lado e eles vão me apresentar um texto } \\
\text { melhorado. E aí eu vejo se ele percebeu que na } \\
\text { palavra deveria ter um acento então ele sabe, ele não } \\
\text { colocou porque não teve atenção, ou ele continua } \\
\text { passando a limpo, reescrevendo, mantendo o mesmo } \\
\text { erro, logo ele não sabe, é um problema conceitual, um } \\
\text { problema na base. }\end{array}$ \\
\hline $\begin{array}{l}\text { Correção de } \\
\text { coerência }\end{array}$ & $\begin{array}{l}\text { O quê corrige: } \\
\text { coerência }\end{array}$ & $\begin{array}{l}\text { Sempre olho primeiro a coerência. Vejo se a ideia foi } \\
\text { bem desenvolvida, se o tema foi bem abordado, se os } \\
\text { argumentos são bons, se o texto é claro, se não fica } \\
\text { dando voltas, se comunica algo. }\end{array}$ \\
\hline $\begin{array}{l}\text { Não corrijo } \\
\text { aspectos } \\
\text { gramaticais }\end{array}$ & $\begin{array}{l}\text { O quê corrige: não } \\
\text { corrige aspectos } \\
\text { gramaticais }\end{array}$ & $\begin{array}{l}\text { Então o que eu tento mais trabalhar com eles que eu } \\
\text { acho que dá para trabalhar, porque essa coisa da } \\
\text { ortografia, da pontuação, isso é uma coisa mais } \\
\text { técnica que eles têm que escrever mesmo. }\end{array}$ \\
\hline Preparo técnico & $\begin{array}{l}\text { O quê corrige: é } \\
\text { preciso preparo } \\
\text { técnico para realizar } \\
\text { correções }\end{array}$ & $\begin{array}{l}\text { [...] como eu não tenho preparo técnico especifico } \\
\text { para trabalhar as dificuldades que eles trazem, eu } \\
\text { acho que é absolutamente imprescindivel, } \\
\text { especialmente nesses casos mais graves, eles terem o } \\
\text { apoio também de alguém especializado, ai na área de } \\
\text { Letras provavelmente. }\end{array}$ \\
\hline $\begin{array}{l}\text { Correção de } \\
\text { tudo }\end{array}$ & $\begin{array}{l}\text { O quê corrige: tudo } \\
\text { na produção textual }\end{array}$ & $\begin{array}{l}\text { Ai eu consigo avaliar como é que eles fazem os } \\
\text { resumos, se sabem escrever, se não sabem, eu corrijo, } \\
\text { corrijo tudo [...]. }\end{array}$ \\
\hline Correção da & O quê corrige: & $O$ texto como um todo, e ai tem a clareza da \\
\hline
\end{tabular}




\begin{tabular}{|c|c|c|}
\hline clareza & $\begin{array}{l}\text { clareza das ideias do } \\
\quad \text { estudante }\end{array}$ & $\begin{array}{l}\text { linguagem, que é um pouco da exatidão, a capacidade } \\
\text { de fazer uma análise crítica, de não reproduzir só o } \\
\text { que o autor pensa }\end{array}$ \\
\hline $\begin{array}{l}\text { Correção da } \\
\text { critica/autoria }\end{array}$ & $\begin{array}{l}\text { O quê corrige: } \text { o } \\
\text { professor analisa a } \\
\text { capacidade crítica do } \\
\text { estudante }\end{array}$ & $\begin{array}{l}\text { O texto como um todo, e aí tem a clareza da } \\
\text { linguagem, que é um pouco da exatidão, a capacidade } \\
\text { de fazer uma análise crítica, de não reproduzir só o } \\
\text { que o autor pensa }\end{array}$ \\
\hline $\begin{array}{l}\text { Correções no } \\
\text { word }\end{array}$ & $\begin{array}{l}\text { Como corrige: no } \\
\text { word }\end{array}$ & $\begin{array}{l}\text { Quando eu tenho texto em formato digital eu faço } \\
\text { como correção do Word [...] }\end{array}$ \\
\hline $\begin{array}{l}\text { Correções nos } \\
\text { textos }\end{array}$ & $\begin{array}{l}\text { Como corrige: nos } \\
\text { próprios trabalhos } \\
\text { dos estudantes }\end{array}$ & $\begin{array}{l}\text { Quando o texto vem escrito para mim eu faço a } \\
\text { correção do mesmo jeito, às vezes um pouquinho mais } \\
\text { contida porque é mais dificil corrigir no papel, mas eu } \\
\text { faço a mesma correção na margem do texto ou no } \\
\text { próprio texto à lápis, em geral eu faço a correção à } \\
\text { lápis. }\end{array}$ \\
\hline $\begin{array}{l}\text { Correções } \\
\text { individuais }\end{array}$ & $\begin{array}{l}\text { Como corrige: } \\
\text { apenas } \\
\text { individualmente }\end{array}$ & $\begin{array}{l}\text { Só individualmente. Em geral os próprios trabalhos } \\
\text { vêm com esses comentários [...]. }\end{array}$ \\
\hline $\begin{array}{l}\text { Correção de } \\
\text { linha por linha }\end{array}$ & $\begin{array}{l}\text { Como corrige: } \\
\text { detalhadamente, } \\
\text { linha por linha }\end{array}$ & $\begin{array}{l}\text { Então, eu faço, eu fazia antes, só marcava na linha, e } \\
\text { isso dá trabalho porque, às vezes, eles vão corrigir o } \\
\text { que está certo, aí eu digo 'se você não entendeu, vem } \\
\text { aqui e me pergunta'. }\end{array}$ \\
\hline Correções orais & $\begin{array}{l}\text { Como corrige: oral e } \\
\text { coletivamente }\end{array}$ & $\begin{array}{l}\text { [...] mas o normal é assim, eu levanto os erros que são } \\
\text { comuns, e ai eu vou para o quadro [...]. }\end{array}$ \\
\hline $\begin{array}{l}\text { Correção após } \\
\text { leitura }\end{array}$ & $\begin{array}{l}\text { Como corrige: o } \\
\text { professor corrige um } \\
\text { texto após a sua } \\
\text { leitura } \\
\text { pormenorizada } \\
\end{array}$ & $\begin{array}{l}\text { [...] eu sempre faço uma leitura do texto inteiro antes } \\
\text { de sair marcando coisas. É preciso ter uma ideia } \\
\text { global do que o aluno construiu. Na segunda leitura } \\
\text { volto marcando. }\end{array}$ \\
\hline $\begin{array}{l}\text { Correções } \\
\text { coletivas }\end{array}$ & $\begin{array}{l}\text { Como corrige: } \\
\text { coletivamente }\end{array}$ & $\begin{array}{l}\text { De alguma forma sim, mas o que eu trabalho } \\
\text { coletivamente é mais a questão da compreensão do } \\
\text { texto. }\end{array}$ \\
\hline $\begin{array}{l}\text { Correções nos } \\
\text { próprios } \\
\text { trabalhos }\end{array}$ & $\begin{array}{l}\text { Como corrige: nos } \\
\text { próprios trabalhos } \\
\text { dos estudantes }\end{array}$ & $\begin{array}{l}\text { Na devolução de trabalhos, nos comentários, tem } \\
\text { sempre comentários, porque tem que justificar, ao } \\
\text { largo do texto eu digo 'precisar', 'não entendi', } \\
\text { 'reescrever'. }\end{array}$ \\
\hline $\begin{array}{l}\text { A grade é } \\
\text { universal }\end{array}$ & $\begin{array}{l}\text { Análise curricular: a } \\
\text { grade de Pedagogia é } \\
\text { pensada para o grupo } \\
\text { como um todo }\end{array}$ & $\begin{array}{l}\text { Eu não sei a grade curricular, porque eu acho que não } \\
\text { é uma grade voltada para os alunos com dificuldade, é } \\
\text { uma grade em um curriculo universal, para todos, } \\
\text { digamos assim. }\end{array}$ \\
\hline $\begin{array}{l}1 \text { disciplina por } \\
\text { vários semestres }\end{array}$ & $\begin{array}{l}\text { Análise curricular: os } \\
\text { estudantes já tem } \\
\text { uma disciplina que } \\
\text { podem cursar por } \\
\text { vários semestres }\end{array}$ & $\begin{array}{l}\text { Sim, até porque eles têm uma disciplina que eles } \\
\text { podem cursar pó vários periodos, eu acho interessante } \\
\text { nesse sentido, que isso é um apoio pra eles, e isso } \\
\text { acaba se tornando uma estratégia interessante. }\end{array}$ \\
\hline $\begin{array}{l}\text { Inclusão de } \\
\text { disciplina de } \\
\text { produção de }\end{array}$ & $\begin{array}{l}\text { Análise curricular: é } \\
\text { necessário a inclusão } \\
\text { de uma disciplina }\end{array}$ & $\begin{array}{l}\text { Se tivesse uma disciplina de produção de texto, alguma } \\
\text { coisa acho que talvez ajudaria. }\end{array}$ \\
\hline
\end{tabular}




\begin{tabular}{|c|c|c|}
\hline textos & obrigatória & \\
\hline $\begin{array}{l}1 \text { disciplina } \\
\text { optativa n é } \\
\text { suficiente }\end{array}$ & $\begin{array}{l}\text { Análise curricular: } \\
\text { apenas uma } \\
\text { disciplina optativa } \\
\text { que trabalha com } \\
\text { escrita não é } \\
\text { suficiente para ajudar } \\
\text { quem precisa de } \\
\text { apoio }\end{array}$ & $\begin{array}{l}\text { Eu acho que uma disciplina para leitura e escrita de } \\
\text { texto não vai ser suficiente. }\end{array}$ \\
\hline $\begin{array}{l}\text { Grade não é } \\
\text { suficiente }\end{array}$ & $\begin{array}{l}\text { Análise curricular: a } \\
\text { grade não é } \\
\text { suficiente, mas já } \\
\text { foram } \\
\text { implementadas } \\
\text { mudanças, ainda não } \\
\text { avaliadas. }\end{array}$ & $\begin{array}{l}\text { Não, não é suficiente. A primeira que você mencionou, } \\
\text { que faz parte do ciclo básico, que não é exatamente do } \\
\text { ciclo básico, é dada em letras [...] E nos vamos } \\
\text { oferecer agora mais, então pessoas com muita } \\
\text { dificuldade vão ter a possibilidade de fazer } 4 \text { optativas } \\
\text { em leitura e escrita, a gente não começou isso ainda, } \\
\text { está começando esse ano, então a gente tem que ver se } \\
\text { isso vai melhorar. A gente não tem nenhum dado sobre } \\
\text { isso ainda para ver se isso melhora o não. }\end{array}$ \\
\hline $\begin{array}{l}4 \text { disciplinas de } \\
\text { leitura e escrita }\end{array}$ & $\begin{array}{l}\text { Análise curricular: o } \\
\text { curso já tem quatro } \\
\text { disciplinas de leitura } \\
\text { e escrita }\end{array}$ & $\begin{array}{l}\text { Neste momento não tenho certeza de como a grade } \\
\text { está organizada. Se estiver respeitando o mínimo que } \\
\text { sugerimos, quatro módulos, quatro semestres, creio } \\
\text { que seja um grande diferencial positivo. }\end{array}$ \\
\hline $\begin{array}{l}\text { Disciplina de } \\
\text { gramatica é } \\
\text { desnecessária }\end{array}$ & $\begin{array}{l}\text { Análise curricular: a } \\
\text { inclusão de uma } \\
\text { disciplina de } \\
\text { gramática é } \\
\text { desnecessária } \\
\end{array}$ & $\begin{array}{l}\text { E também eu não acho que é questão de fazer } \\
\text { disciplinas de gramática, eu acho que eles podem } \\
\text { aprender isso muito mais como você aprende uma } \\
\text { segunda língua do que a primeira língua aqui no } \\
\text { Brasil [...]. }\end{array}$ \\
\hline $\begin{array}{l}\text { É uma das } \\
\text { preocupações do } \\
\text { currículo }\end{array}$ & $\begin{array}{l}\text { Análise curricular: a } \\
\text { escrita é uma das } \\
\text { preocupações do } \\
\text { currículo }\end{array}$ & $\begin{array}{l}\text { [...] penso que nessa ultima mudança da grade } \\
\text { curricular, essa foi uma das preocupaçós do curso, e } \\
\text { a gente conseguiu avançar em algumas coisas, me } \\
\text { parece. }\end{array}$ \\
\hline $\begin{array}{l}\text { As disciplinas } \\
\text { que têm ajudam }\end{array}$ & $\begin{array}{l}\text { Análise curricular: as } \\
\text { disciplinas que } \\
\text { existem ajudam os } \\
\text { estudantes que } \\
\text { precisam }\end{array}$ & $\begin{array}{l}\text { E eu acho que essas duas disciplinas elas ajudam, elas } \\
\text { contribuem. }\end{array}$ \\
\hline $\begin{array}{l}1 \text { disciplina } \\
\text { obrigatória eh } \\
\text { pouco }\end{array}$ & $\begin{array}{l}\text { Análise curricular: } \\
\text { apenas uma } \\
\text { disciplina obrigatória } \\
\text { para trabalhar com } \\
\text { escrita é pouco }\end{array}$ & $\begin{array}{l}\text { Agora acho que ainda é pouco, resumido a uma } \\
\text { disciplina, entende. }\end{array}$ \\
\hline $\begin{array}{l}\text { Criar disciplina } \\
\text { de LEITURA E } \\
\text { ESCRITA como } \\
\text { obrigatória } \\
\end{array}$ & $\begin{array}{l}\text { Análise curricular: a } \\
\text { disciplina Leitura e } \\
\text { Escrita deveria ser } \\
\text { obrigatória }\end{array}$ & $\begin{array}{l}\text { Não, eu acho que deveria ter mais. Por exemplo } \\
\text { 'Leitura e escrita } \text { não deveria ser optativa, } \\
\text { você está me dizendo que é optativa e eu achava que } \\
\text { era obrigatória, acho que deveria ser obrigatória. }\end{array}$ \\
\hline $\begin{array}{l}\text { Especificidades } \\
\text { dos cursos }\end{array}$ & $\begin{array}{l}\text { Análise curricular: } \\
\text { cada curso tem suas } \\
\text { particularidades }\end{array}$ & $\begin{array}{l}\text { [...] eu acho que cada Departamento, cada curso, tem } \\
\text { mais condições de avaliar quais são as reais } \\
\text { necessidades dos alunos enfim. }\end{array}$ \\
\hline
\end{tabular}




\begin{tabular}{|c|c|c|}
\hline $\begin{array}{l}\text { Trb coletivo de } \\
\text { todos os profs }\end{array}$ & $\begin{array}{l}\text { Sugestão do } \\
\text { professor para ajudar } \\
\text { o aluno que precisa } \\
\text { de apoio: trabalho } \\
\text { coletivo de todos os } \\
\text { professores }\end{array}$ & $\begin{array}{l}\text { Eu acho que isso tinha que ser, de certa maneira, uma } \\
\text { responsabilidade de todos os professores, eu acho que } \\
\text { isso é uma questão que tinha que ser assumida mais } \\
\text { coletivamente. }\end{array}$ \\
\hline $\begin{array}{c}\text { É preciso } \\
\text { intervenção }\end{array}$ & $\begin{array}{l}\text { Sugestão do } \\
\text { professor para ajudar } \\
\text { o aluno que precisa } \\
\text { de apoio: maior } \\
\text { intervenção do } \\
\text { professor } \\
\end{array}$ & $\begin{array}{l}\text { Eu acho que é tarefa de todo professor porque a gente } \\
\text { aprende a escrever escrevendo, e eu só modifico a } \\
\text { minha escrita se eu sou orientada para isso. Eu não } \\
\text { aprendo sozinha, a minha escrita não vai evoluir, não } \\
\text { vai ser modificada simplesmente pelo exercício da } \\
\text { escrita. }\end{array}$ \\
\hline $\begin{array}{c}\text { Recuperação } \\
\text { paralela }\end{array}$ & $\begin{array}{l}\text { Sugestão do } \\
\text { professor para ajudar } \\
\text { o aluno que precisa } \\
\text { de apoio: promover } \\
\text { uma espécie de } \\
\text { recuperação } \\
\end{array}$ & $\begin{array}{l}\text { Eu vou entrar na recuperação paralela lá da } \\
\text { escolinha. Recuperação paralela, o reforço. É, eu diria } \\
\text { que precisaria de mais tempo, poderia até fazer } \\
\text { mesmo, não com esse nome, mas de } 15 \mathrm{em} 15 \text { dias, } \\
\text { uma vez por semana. }\end{array}$ \\
\hline $\begin{array}{l}\text { Operar com a } \\
\text { leitura }\end{array}$ & $\begin{array}{l}\text { Sugestão do } \\
\text { professor para ajudar } \\
\text { o aluno que precisa } \\
\text { de apoio: incentivar a } \\
\text { leitura }\end{array}$ & $\begin{array}{l}\text { Operar com leitura. Sem dúvida! Não adianta querer } \\
\text { fazer escrever quem não tem o que dizer. Lendo, o } \\
\text { aluno, além de se informar, passa a ter contato com } \\
\text { estruturas complexas, bem organizadas. }\end{array}$ \\
\hline $\begin{array}{l}\text { Criação de } \\
\text { oficinas }\end{array}$ & $\begin{array}{l}\text { Sugestão do } \\
\text { professor para ajudar } \\
\text { o aluno que precisa } \\
\text { de apoio: criação de } \\
\text { oficinas }\end{array}$ & $\begin{array}{l}\text { Um jornal, propor alguma atividade através do } C A \text {, } \\
\text { um jornal da Pedagogia que teria que ser pelo próprio } \\
C A \text {, pelos estudantes, envolvendo algumas atividades } \\
\text { que fossem conjuntas com os alunos, acho que seria } \\
\text { interessante, acho que seria bacana. }\end{array}$ \\
\hline $\begin{array}{l}\text { Nivelamento em } \\
\text { todas as áreas }\end{array}$ & $\begin{array}{l}\text { Sugestão do } \\
\text { professor para ajudar } \\
\text { o aluno que precisa } \\
\text { de apoio: }\end{array}$ & $\begin{array}{l}{[. . .] \text { eu acho que eles precisam se submeter a teste de }} \\
\text { nivelamento não apenas em língua portuguesa, mas em } \\
\text { todas as áreas [...] }\end{array}$ \\
\hline $\begin{array}{l}\text { Pessoas } \\
\text { especializadas }\end{array}$ & $\begin{array}{l}\text { Sugestão do } \\
\text { professor para ajudar } \\
\text { o aluno que precisa } \\
\text { de apoio: pessoas de } \\
\text { outras áreas }\end{array}$ & $\begin{array}{l}{[. . .] \text { você precisaria ter, talvez, um número maior de }} \\
\text { pessoas especializadas em outras áreas }\end{array}$ \\
\hline $\begin{array}{l}\text { Mais tempo de } \\
\text { CURSO }\end{array}$ & $\begin{array}{l}\text { Sugestão do } \\
\text { professor para ajudar } \\
\text { o aluno que precisa } \\
\text { de apoio }\end{array}$ & $\begin{array}{l}\text { [...] muito mais tempo de curso para dar conta de } \\
\text { todas essas coisas como se deveria ser. Eu diria que } \\
\text { um aluno, salvo engano, de um modo geral, um aluno } \\
\text { de pedagogia teria que estudar tempo integral, pelo } \\
\text { menos três anos, depois começar a fazer estágio com } \\
\text { acompanhamento etc e tal. }\end{array}$ \\
\hline $\begin{array}{l}\text { Nivelamento é } \\
\text { importante }\end{array}$ & $\begin{array}{l}\text { Sugestão do } \\
\text { professor para ajudar } \\
\text { o aluno que precisa } \\
\text { de apoio: exigir o } \\
\text { nivelamento }\end{array}$ & $\begin{array}{l}\text { Exigir efetivamente dos alunos um preparo para esse } \\
\text { nivelamento, porque muitos são reprovados. São } \\
\text { reprovados porque não sabem escrever um texto com } \\
\text { início, meio efim. }\end{array}$ \\
\hline
\end{tabular}




\begin{tabular}{|c|c|c|}
\hline $\begin{array}{l}\text { Contato com } \\
\text { outros } \\
\text { ambientes } \\
\text { culturais }\end{array}$ & $\begin{array}{l}\text { Sugestão do } \\
\text { professor para ajudar } \\
\text { o aluno que precisa } \\
\text { de apoio: promover o } \\
\text { contato com outros } \\
\text { ambientes sociais e } \\
\text { culturais }\end{array}$ & $\begin{array}{l}\text { Acho que a exposição à cultura, ao teatro, ao cinema, } \\
\text { música são práticas muito importantes, fazem parte da } \\
\text { formação cultural desse professor. }\end{array}$ \\
\hline $\begin{array}{l}\text { Criação de mini } \\
\text { biblioteca }\end{array}$ & $\begin{array}{l}\text { Sugestão do } \\
\text { professor para ajudar } \\
\text { o aluno que precisa } \\
\text { de apoio: criação de } \\
\text { mini biblioteca }\end{array}$ & $\begin{array}{l}\text { [...] uma coisa que pode ajudar é disponibilizar uma } \\
\text { mini biblioteca, uma indicação de textos para os } \\
\text { alunos que têm algum tipo de problema com a escrita. }\end{array}$ \\
\hline $\begin{array}{l}\text { Nivelamento é } \\
\text { desnecessário }\end{array}$ & $\begin{array}{l}\text { Sugestão do } \\
\text { professor para ajudar } \\
\text { o aluno que precisa } \\
\text { de apoio: o } \\
\text { nivelamento não é } \\
\text { necessário }\end{array}$ & $\begin{array}{l}\text { [...] não é uma questão de uma prova, é uma questão } \\
\text { processual, não interessa como meu aluno chegou, } \\
\text { interessa como ele vai sair. }\end{array}$ \\
\hline $\begin{array}{l}\text { Núcleo } \\
\text { especializado } \\
\text { pode ajudar }\end{array}$ & $\begin{array}{l}\text { Sugestão do } \\
\text { professor para ajudar } \\
\text { o aluno que precisa } \\
\text { de apoio: o núcleo } \\
\text { especializado pode } \\
\text { ajudar no trabalho } \\
\text { com os alunos } \\
\end{array}$ & $\begin{array}{l}\dot{E} \text { claro que se a pessoa continuar com alto nível de } \\
\text { dificuldade, aí sim, eu acredito que é para isso que } \\
\text { vocês estão pesquisando, acredito que o (núcleo) possa } \\
\text { ajudar a resolver, mas eu acho que... não sei como é } \\
\text { feito o trabalho lá, eu tenho uma ideia muito vaga } \\
\text { então não posso dar nenhuma sugestão. }\end{array}$ \\
\hline $\begin{array}{l}\text { Todos os cursos } \\
\text { têm problemas } \\
\text { de escrita }\end{array}$ & $\begin{array}{l}\text { Não é apenas o curso } \\
\text { de Pedagogia que } \\
\text { tem alunos com } \\
\text { problemas de escrita }\end{array}$ & $\begin{array}{l}\text { Nas discussões entre nós, é um dos problemas mais } \\
\text { levantados e discutidos em reuniões de professores } \\
\text { [...] é um problema agora que, não somente nos, } \\
\text { quando falo com colegas em outros departamentos } \\
\text { todo mundo percebo os mesmos problemas [...]. }\end{array}$ \\
\hline $\begin{array}{l}\text { Optativa como } \\
\text { optativa }\end{array}$ & $\begin{array}{l}\text { A disciplina optativa } \\
\text { não deve se tornar } \\
\text { obrigatória, mas sim } \\
\text { permanecer optativa }\end{array}$ & $\begin{array}{l}\text { Eu acho que ela deve ficar como optativa, mas a gente } \\
\text { precisa observar os alunos e indicar aqueles que têm } \\
\text { necessidade de fazer a disciplina. }\end{array}$ \\
\hline $\begin{array}{c}\text { Obrigatória com } \\
\text { maior duração }\end{array}$ & $\begin{array}{l}\text { A disciplina (nome } \\
\text { da disciplina) } \\
\text { deveria ter maior } \\
\text { duração } \\
\end{array}$ & $\begin{array}{l}\dot{E} \text {, uma disciplina que durasse mais, que tivesse mais } \\
\text { um periodo, essa seria a minha sugestão. }\end{array}$ \\
\hline $\begin{array}{l}\text { Mais tempo p a } \\
\text { optativa }\end{array}$ & $\begin{array}{l}\text { A disciplina Leitura } \\
\text { e Escrita deveria ter } \\
\text { maior tempo de } \\
\text { duração }\end{array}$ & $\begin{array}{l}\text { Um semestre é muito pouco. Tanto que a ideia do } \\
\text { departamento (e estou desatualizado se foi ou não } \\
\text { colocada em prática) era estender a disciplina em } \\
\text { quatro módulos, quatro semestres. }\end{array}$ \\
\hline $\begin{array}{l}* \text { Disciplina } \\
\text { cansativa }\end{array}$ & $\begin{array}{c}\text { Como o estudante } \\
\text { avalia a disciplina: } \\
\text { cansativa }\end{array}$ & Dificil. Cansativa. \\
\hline * Disciplina fácil & $\begin{array}{l}\text { Como o estudante } \\
\text { avalia a disciplina: }\end{array}$ & Foi fácil, mas a organização não contribuiu. \\
\hline
\end{tabular}




\begin{tabular}{|c|c|c|}
\hline & fácil & \\
\hline $\begin{array}{l}* \text { Disciplina } \\
\text { proveitosa }\end{array}$ & $\begin{array}{l}\text { Como o estudante } \\
\text { avalia a disciplina: } \\
\text { proveitosa }\end{array}$ & Eu achei proveitosa. \\
\hline $\begin{array}{l}* \text { Liberdade } \\
\text { para o aluno }\end{array}$ & $\begin{array}{l}\text { Como o estudante } \\
\text { avalia a disciplina: } \\
\text { houve liberdade para } \\
\text { o aluno }\end{array}$ & $\begin{array}{l}\text { Ela deu um espaço para a gente escolher o tema, então } \\
\text { eu acho que isso é legal da parte dela. Tipo assim...... } \\
\text { individual, mas é importante também aprender a fazer } \\
\text { isso. }\end{array}$ \\
\hline $\begin{array}{l}\text { * Disciplina } \\
\text { tranquila }\end{array}$ & $\begin{array}{l}\text { Como o estudante } \\
\text { avalia a disciplina: } \\
\text { tranquila }\end{array}$ & $\begin{array}{l}\text { E todo mundo achou que fosse ficar muito cansativo, } \\
\text { que não fosse gostar porque era direto, mas era super } \\
\text { tranquilo. Eu acho que foi unânime isso. }\end{array}$ \\
\hline $\begin{array}{l}* \text { Disciplina } \\
\text { produtiva }\end{array}$ & $\begin{array}{l}\text { Como o estudante } \\
\text { avalia a disciplina: } \\
\text { produtiva }\end{array}$ & $\begin{array}{l}\text { E também foi muito produtivo. A gente produziu } \\
\text { bastante, dava para acompanhar, acho que foi bem } \\
\text { tranquilo. }\end{array}$ \\
\hline $\begin{array}{l}* \text { Superou } \\
\text { expectativas }\end{array}$ & $\begin{array}{l}\text { Como o estudante } \\
\text { avalia a disciplina: } \\
\text { superou expectativas }\end{array}$ & $\begin{array}{l}\text { Não correspondeu às minhas expectativas não, foi } \\
\text { além das minhas expectativas. }\end{array}$ \\
\hline $\begin{array}{l}* \text { Disciplina } \\
\text { flexível }\end{array}$ & $\begin{array}{l}\text { Como o estudante } \\
\text { avalia a disciplina: } \\
\text { flexível }\end{array}$ & $\begin{array}{l}\text { [...] era muito flexível. A questão do horário [...] E } \\
\text { fazer os trabalhos em sala eu acho que isso ajuda } \\
\text { muito porque a gente já está ali, a nossa concentração } \\
\text { já está ali. }\end{array}$ \\
\hline $\begin{array}{l}* \text { Disciplina } \\
\text { enriquecedora }\end{array}$ & $\begin{array}{l}\text { Como o estudante } \\
\text { avalia a disciplina: } \\
\text { enriquecedora }\end{array}$ & $\begin{array}{l}\text { Toda aula você sai com essa sensação, tipo eu fiz } \\
\text { alguma coisa, não fui só para a aula para não ganhar } \\
\text { falta. }\end{array}$ \\
\hline $\begin{array}{c}* \text { Superou } \\
\text { expectativas }\end{array}$ & $\begin{array}{l}\text { Como o estudante } \\
\text { avalia a disciplina: }\end{array}$ & $\begin{array}{l}\text { Não correspondeu às minhas expectativas não, foi } \\
\text { além das minhas expectativas. }\end{array}$ \\
\hline * Prof boa & $\begin{array}{l}\text { Como o estudante } \\
\text { avalia o professor: } \\
\text { bom }\end{array}$ & $\begin{array}{l}\text { Eu, particularmente, acho que ela é uma professora } \\
\text { muito boa }\end{array}$ \\
\hline *Prof atenciosa & $\begin{array}{l}\text { Como o estudante } \\
\text { avalia o professor: } \\
\text { atencioso }\end{array}$ & [...] corrige detalhadamente \\
\hline * Prof detalhista & $\begin{array}{l}\text { Como o estudante } \\
\text { avalia o professor: } \\
\text { detalhista }\end{array}$ & [...] dá muita atenção aos detalhes. \\
\hline $\begin{array}{l}* \text { Prof } \\
\text { apaixonado }\end{array}$ & $\begin{array}{l}\text { Como o estudante } \\
\text { avalia o professor: } \\
\text { apaixonado }\end{array}$ & $\begin{array}{l}\text { Era por prazer porque ele é uma pessoa muito boa, } \\
\text { instiga muito a escrever, é muito apaixonado pelo que } \\
\text { faz, na fala dele você percebe, e acaba que te traz um } \\
\text { pouco para o mundo dele. }\end{array}$ \\
\hline * Prof acessível & $\begin{array}{l}\text { Como o estudante } \\
\text { avalia o professor: } \\
\text { acessível }\end{array}$ & $\begin{array}{l}{[\ldots] \text { era completamente acessivel, sempre presente, }} \\
\text { respondia e-mail, também no facebook se precisasse } \\
\text { falar alguma coisa com ele. }\end{array}$ \\
\hline * Prof instigante & $\begin{array}{l}\text { Como o estudante } \\
\text { avalia o professor: } \\
\text { instigante }\end{array}$ & $\begin{array}{l}\text { E o jeito da professora de conduzir as aulas, ela vai te } \\
\text { apontando a voce querer ler mais. }\end{array}$ \\
\hline $\begin{array}{l}* \text { Prof que } \\
\text { domina } 0 \\
\text { assunto }\end{array}$ & $\begin{array}{l}\text { Como o estudante } \\
\text { avalia o professor: } \\
\text { que domina o }\end{array}$ & $\begin{array}{l}\text { E sem contar os autores, ela falava sobre os autores } \\
\text { com muita propriedade, ela falava sobre os livros com } \\
\text { muita propriedade, sobre os diferentes tipos de }\end{array}$ \\
\hline
\end{tabular}




\begin{tabular}{|c|c|c|}
\hline & assunto & gêneros textuais com muita propriedade. \\
\hline $\begin{array}{l}\text { * Aprenderam: } \\
\text { resumo }\end{array}$ & $\begin{array}{l}\text { O que os estudantes } \\
\text { aprenderam na } \\
\text { disciplina: fazer } \\
\text { resumo }\end{array}$ & Resumo \\
\hline * Coesão & $\begin{array}{l}\text { O que os estudantes } \\
\text { aprenderam na } \\
\text { disciplina: coesão }\end{array}$ & Mapa conceitual. Coerência e coesão. \\
\hline $\begin{array}{l}* \text { Mapa } \\
\text { conceitual }\end{array}$ & $\begin{array}{l}\text { O que os estudantes } \\
\text { aprenderam na } \\
\text { disciplina: fazer } \\
\text { mapa conceitual }\end{array}$ & Mapa conceitual. Coerência e coesão. \\
\hline * Coerência & $\begin{array}{l}\text { O que os estudantes } \\
\text { aprenderam na } \\
\text { disciplina: coerência }\end{array}$ & Mapa conceitual. Coerência e coesão. \\
\hline $\begin{array}{l}\text { * Treinar } \\
\text { apresentação }\end{array}$ & $\begin{array}{l}\text { O que os estudantes } \\
\text { aprenderam na } \\
\text { disciplina: treinar } \\
\text { apresentação }\end{array}$ & $\begin{array}{l}\text { A gente vai apresentar agora nas últimas aulas um } \\
\text { trabalho e eu acho que isso é muito legal também, } \\
\text { treinar apresentação, porque nós não estamos } \\
\text { acostumados com isso. }\end{array}$ \\
\hline $\begin{array}{c}\text { * Ortografia de } \\
\text { forma } \\
\text { processual }\end{array}$ & $\begin{array}{l}\text { O que os estudantes } \\
\text { aprenderam na } \\
\text { disciplina: ortografia } \\
\text { como processo }\end{array}$ & $\begin{array}{l}\text { Mas ortografia não dá pra ser em uma aula, ia ter que } \\
\text { dedicar um mês, porque é muito abrangente. } \\
\text { Ortografia é mais rever nossos erros do que ensinar. }\end{array}$ \\
\hline $\begin{array}{c}* \begin{array}{c}\text { Pontuação de } \\
\text { forma } \\
\text { processual }\end{array} \\
\end{array}$ & $\begin{array}{l}\text { O que os estudantes } \\
\text { aprenderam na } \\
\text { disciplina: pontuação }\end{array}$ & $\begin{array}{l}\text { [...] vírgula [...] Não foi uma aula específica, mas eu } \\
\text { também não acho que deveria ser. }\end{array}$ \\
\hline $\begin{array}{l}\text { * Aprenderam } \\
\text { gramática }+ \\
\text { produção }\end{array}$ & $\begin{array}{l}\text { O que os estudantes } \\
\text { aprenderam na } \\
\text { disciplina: aspectos } \\
\text { gramaticais e de } \\
\text { produção de texto }\end{array}$ & $\begin{array}{l}\text { Ele deu algumas folhas de exercício também, próprias, } \\
\text { pela dificuldade que a gente tinha. Eu lembro que, no } \\
\text { início, ele tinha pedido para a gente escrever, ele foi } \\
\text { falando e nós fomos escrevendo nossas impressões } \\
\text { sobre um texto que ele tinha lido, que ele foi lendo } \\
\text { para a gente.. }\end{array}$ \\
\hline $\begin{array}{l}* \text { Trabalhar a } \\
\text { reescritura }\end{array}$ & $\begin{array}{l}\text { O que os estudantes } \\
\text { aprenderam na } \\
\text { disciplina: como } \\
\text { reescrever }\end{array}$ & $\begin{array}{l}\text { E o ato de você reescrever, você faz uma reflexão } \\
\text { sobre o que você está lendo, eu acho que foi o que } \\
\text { ajudou mais. }\end{array}$ \\
\hline $\begin{array}{l}\text { * Gosto pela } \\
\text { leitura }\end{array}$ & $\begin{array}{l}\text { O que os estudantes } \\
\text { aprenderam na } \\
\text { disciplina: } \\
\text { desenvolver o gosto } \\
\text { pela leitura }\end{array}$ & $\begin{array}{l}\text { Eu acho que também não foi só na questão da escrita, } \\
\text { mas da leitura. }\end{array}$ \\
\hline $\begin{array}{l}* \text { Diferentes } \\
\text { gêneros textuais }\end{array}$ & $\begin{array}{l}\text { O que os estudantes } \\
\text { aprenderam na } \\
\text { disciplina: gêneros } \\
\text { textuais }\end{array}$ & $\begin{array}{l}\text { Diferentes gêneros textuais, todos os gêneros textuais } \\
\text { quase. }\end{array}$ \\
\hline $\begin{array}{l}* \text { Prazer na } \\
\text { escrita }\end{array}$ & $\begin{array}{l}\text { O que os estudantes } \\
\text { aprenderam na } \\
\text { disciplina: prazer na }\end{array}$ & $\begin{array}{l}\text { E nisso a minha escrita foi aprimorando [...] era pelo } \\
\text { prazer de produzir a partir do que eu compreendi, e } \\
\text { aquilo fez diferença para mim, então eu tinha prazer }\end{array}$ \\
\hline
\end{tabular}




\begin{tabular}{|c|c|c|}
\hline & escrita & $\begin{array}{l}\text { em escrever, eu tinha prazer em procurar, eu tinha } \\
\text { prazer em ler aquilo [...]. }\end{array}$ \\
\hline $\begin{array}{l}* \text { Profs da EB n } \\
\text { atenciosos }\end{array}$ & $\begin{array}{l}\text { Relação que o aluno } \\
\text { estabelece sobre seu } \\
\text { desempenho e sua } \\
\text { escolarização } \\
\text { anterior: professores } \\
\text { da Educação Básica } \\
\text { não são atenciosos }\end{array}$ & $\begin{array}{l}\text { Porque na escola a minha professora, por exemplo, } \\
\text { também passava muito tempo falando da vida pessoal } \\
\text { dela, deixava os últimos vinte minutos para ensinar } \\
\text { alguma coisa mesmo. }\end{array}$ \\
\hline * EM fraco & $\begin{array}{c}\text { Relação que o aluno } \\
\text { estabelece sobre seu } \\
\text { desempenho e sua } \\
\text { escolarização } \\
\text { anterior: Ensino } \\
\text { Médio fraco }\end{array}$ & $\begin{array}{l}\text { O ensino médio não prepara a gente para a } \\
\text { universidade, nem um pouco. }\end{array}$ \\
\hline $\begin{array}{l}* \text { EM } \\
\text { preocupado com } \\
\text { ENEM }\end{array}$ & $\begin{array}{l}\text { Relação que o aluno } \\
\text { estabelece sobre seu } \\
\text { desempenho e sua } \\
\text { escolarização } \\
\text { anterior: Ensino } \\
\text { Médio preocupado } \\
\text { com o ENEM }\end{array}$ & $\begin{array}{l}\text { Eu não sei, é que no ensino médio é uma coisa mais de } \\
\text { sistema, tipo Enem. }\end{array}$ \\
\hline $\begin{array}{l}\text { * Falta de acesso } \\
\text { na EB }\end{array}$ & $\begin{array}{c}\text { Relação que o aluno } \\
\text { estabelece sobre seu } \\
\text { desempenho e sua } \\
\text { escolarização } \\
\text { anterior: na } \\
\text { Educação Básica não } \\
\text { proporcionam acesso } \\
\text { a outros bens } \\
\text { culturais }\end{array}$ & $\begin{array}{l}\text { Eu acho que a gente aprendeu, a maioria nunca tinha } \\
\text { tido acesso, a gente não tinha dado na escola. No } \\
\text { começo a gente ficou meio assustada. }\end{array}$ \\
\hline $\begin{array}{l}* \text { EM } \\
\text { proporcionou } \\
\text { prática }\end{array}$ & $\begin{array}{l}\text { Relação que o aluno } \\
\text { estabelece sobre seu } \\
\text { desempenho e sua } \\
\text { escolarização } \\
\text { anterior: Ensino } \\
\text { Médio proporcionou } \\
\text { prática de escrita }\end{array}$ & $\begin{array}{l}\text { Para mim melhorou. Porque assim, desde lá o ensino } \\
\text { médio eu sempre tive, por causa do vestibular, eu tive } \\
\text { um ano inteiro só de redação, eu tive só uma disciplina } \\
\text { de redação. }\end{array}$ \\
\hline * Defasagem & $\begin{array}{l}\text { Relação que o aluno } \\
\text { estabelece sobre seu } \\
\text { desempenho e sua } \\
\text { escolarização } \\
\text { anterior: a defasagem } \\
\text { é grande }\end{array}$ & $\begin{array}{l}\text { [...] a gente chega com uma defasagem muito grande. } \\
\text { E eu acho que isso é geral. }\end{array}$ \\
\hline $\begin{array}{l}\quad * \text { EM n } \\
\text { incentiva leitura }\end{array}$ & $\begin{array}{l}\text { Relação que o aluno } \\
\text { estabelece sobre seu } \\
\text { desempenho e sua } \\
\text { escolarização }\end{array}$ & $\begin{array}{l}\text { Eu acho que também não foi só na questão da escrita, } \\
\text { mas da leitura. Porque pelo menos eu, no ensino } \\
\text { médio, eu não lia praticamente nada. }\end{array}$ \\
\hline
\end{tabular}




\begin{tabular}{|c|c|c|}
\hline & $\begin{array}{l}\text { anterior: Ensino } \\
\text { Médico não incentiva } \\
\text { a leitura }\end{array}$ & \\
\hline $\begin{array}{l}\text { * Agilidade na } \\
\text { interpretação e } \\
\text { escrita }\end{array}$ & $\begin{array}{l}\text { O que os estudantes } \\
\text { aprenderam nas } \\
\text { disciplinas } \\
\text { específicas }\end{array}$ & Agilidade na interpretação e escrita. \\
\hline $\begin{array}{l}* \mathbf{N} \text { houve } \\
\text { mudanças }\end{array}$ & $\begin{array}{l}\text { O aluno não } \\
\text { percebeu mudanças } \\
\text { em seu } \\
\text { desenvolvimento }\end{array}$ & $\begin{array}{l}\text { Pra mim eu estou a mesma coisa de quando entrei na } \\
\text { disciplina. }\end{array}$ \\
\hline $\begin{array}{l}* \text { Cuidado p } \\
\text { escrever }\end{array}$ & $\begin{array}{l}\text { O que os estudantes } \\
\text { aprenderam nas } \\
\text { disciplinas } \\
\text { específicas }\end{array}$ & $\begin{array}{l}\text { Eu acho que para mim o que mais significou foi ter } \\
\text { mais cuidado na hora de escrever. }\end{array}$ \\
\hline $\begin{array}{l}* \text { Perceber os } \\
\quad \text { erros }\end{array}$ & $\begin{array}{l}\text { O que os estudantes } \\
\text { aprenderam nas } \\
\text { disciplinas } \\
\text { específicas: } \\
\text { capacidade de } \\
\text { perceber erros }\end{array}$ & $\begin{array}{l}\text { Eu acho que para mim o que mais significou foi ter } \\
\text { mais cuidado na hora de escrever. E os erros, têm } \\
\text { muitos erros, eu acho que isso ficou mais. E a questão } \\
\text { do resumo. }\end{array}$ \\
\hline $\begin{array}{l}* \text { Saber fazer } \\
\text { resumo }\end{array}$ & $\begin{array}{l}\text { O que os estudantes } \\
\text { aprenderam nas } \\
\text { disciplinas } \\
\text { específicas: } \\
\text { construção de } \\
\text { resumos }\end{array}$ & $\begin{array}{l}\text { Eu acho que a coisa de saber sintetizar, por causa dos } \\
\text { resumos, eu aprendi um pouquinho }\end{array}$ \\
\hline $\begin{array}{l}* \mathrm{~N} \text { existe } \\
\text { consenso sobre a } \\
\text { melhoria }\end{array}$ & $\begin{array}{l}\text { Uma sequência de } \\
\text { falas mostra que não } \\
\text { existe consenso sobre } \\
\text { melhorias no grupo }\end{array}$ & $\begin{array}{l}\text { Estudante } 6 \text { - A mesma coisa. } \\
\text { Estudante } 12 \text { - Pra mim melhorou, não muito, mas... }\end{array}$ \\
\hline $\begin{array}{l}* \text { Escrita } \\
\text { tranquila }\end{array}$ & $\begin{array}{l}\text { O que os estudantes } \\
\text { aprenderam nas } \\
\text { disciplinas } \\
\text { específicas: escrita } \\
\text { tranquila }\end{array}$ & $\begin{array}{l}\text { Eu acho que fez muita diferença. Eu acho que hoje eu } \\
\text { escrevo com muito mais tranquilidade do que quando } \\
\text { eu escrevia lá no início. }\end{array}$ \\
\hline $\begin{array}{l}* \text { Houve } \\
\text { progresso }\end{array}$ & $\begin{array}{l}\text { O que os estudantes } \\
\text { aprenderam nas } \\
\text { disciplinas } \\
\text { específicas: o } \\
\text { progresso é } \\
\text { perceptível }\end{array}$ & $\begin{array}{l}\text { Houve progresso sim e, pelo menos no meu caso, eu } \\
\text { tinha muitas dúvidas de como começar um texto, de } \\
\text { como terminar, e eu acho que isso foi um grande } \\
\text { diferencial. }\end{array}$ \\
\hline $\begin{array}{l}* \text { Escrita de } \\
\text { qualidade }\end{array}$ & $\begin{array}{l}\text { O que os estudantes } \\
\text { aprenderam nas } \\
\text { disciplinas } \\
\text { específicas: produção } \\
\text { de textos com maior } \\
\text { qualidade }\end{array}$ & $\begin{array}{l}\text { ela conseguiu fazer com que o livro nos prendesse, e } \\
\text { com isso você vai enriquecendo seu vocabulário e } \\
\text { conseguindo produzir textos de maior qualidade. }\end{array}$ \\
\hline
\end{tabular}




\begin{tabular}{|c|c|c|}
\hline $\begin{array}{l}* \text { Profs n } \\
\text { avaliam }\end{array}$ & $\begin{array}{l}\text { Como os alunos } \\
\text { dizem que os } \\
\text { professores do curso, } \\
\text { em geral, se } \\
\text { preocupam com a sua } \\
\text { escrita: os } \\
\text { professores não } \\
\text { avaliam }\end{array}$ & Eles não manifestam nada, pelo menos comigo. \\
\hline $\begin{array}{l}\text { * Apenas } 1 \text { prof } \\
\text { comenta }\end{array}$ & $\begin{array}{l}\text { Como os alunos } \\
\text { dizem que os } \\
\text { professores do curso, } \\
\text { em geral, se } \\
\text { preocupam com a sua } \\
\text { escrita: apenas uma } \\
\text { professora comenta }\end{array}$ & $\begin{array}{l}\text { Tem uma professora que ela sempre comenta o } \\
\text { progresso da turma em geral em relação a isso, tanto } \\
\text { a escrita quanto o se colocar ao falar para a turma, } \\
\text { tem uma professora que observa, mas que eu me } \\
\text { lembre é a única. }\end{array}$ \\
\hline $\begin{array}{c}\text { * Períodos } \\
\text { iniciais têm } \\
\text { maior atenção }\end{array}$ & $\begin{array}{l}\text { Como os alunos } \\
\text { dizem que os } \\
\text { professores do curso, } \\
\text { em geral, se } \\
\text { preocupam com a sua } \\
\text { escrita: a } \\
\text { preocupação é maior } \\
\text { com alunos iniciantes }\end{array}$ & $\begin{array}{l}\text { Mas acho que, no inicio, nos primeiros periodos são os } \\
\text { que os professores mais nos ajudam na hora de } \\
\text { escrever, que mais pontuam, porque eles entendem que } \\
\text { a gente chegou agora a gente tem mais dificuldade. }\end{array}$ \\
\hline $\begin{array}{c}\text { * Profs n } \\
\text { acessíveis }\end{array}$ & $\begin{array}{l}\text { Como os alunos } \\
\text { dizem que os } \\
\text { professores do curso, } \\
\text { em geral, se } \\
\text { preocupam com a sua } \\
\text { escrita: professores } \\
\text { não são acessíveis } \\
\end{array}$ & $\begin{array}{l}\text { Em alguns poucos sim, mas não da maneira como ela } \\
\text { faz. É muito limitado, ele até para e ouve, mas não } \\
\text { quer dizer que ele vá considerar, que ele vá explicar, } \\
\text { que é uma outra questão. }\end{array}$ \\
\hline $\begin{array}{l}\text { * Alguns profs n } \\
\text { são exemplo }\end{array}$ & $\begin{array}{l}\text { Como os alunos } \\
\text { dizem que os } \\
\text { professores do curso, } \\
\text { em geral, se } \\
\text { preocupam com a sua } \\
\text { escrita: alguns } \\
\text { professores não são } \\
\text { exemplo da profissão } \\
\text { docente }\end{array}$ & $\begin{array}{l}\text { Assim, o que eu vejo nessa disciplina, é alguns } \\
\text { professores da Pedagogia, alguns são exemplo do que } \\
\text { se deve fazer, do que você aprende, do que você } \\
\text { estuda, e alguns não, porque o que ele fala é uma } \\
\text { coisa e o que ele ensina é outra coisa totalmente } \\
\text { diferente. Então ele ensina uma coisa, mas ele } \\
\text { enquanto professor, a didática dele, a metodologia } \\
\text { dele não condiz com aquilo que ele está ensinando. }\end{array}$ \\
\hline $\begin{array}{l}\text { * Disciplinas n } \\
\text { dialogam }\end{array}$ & $\begin{array}{l}\text { As disciplinas do } \\
\text { Curso não dialogam } \\
\text { entre si }\end{array}$ & $\begin{array}{l}\text { Não é um curso que as disciplinas conversam entre, si } \\
\text { são muito fragmentadas, é cada um no seu espaço. }\end{array}$ \\
\hline
\end{tabular}

